Prepared in cooperation with South Carolina Department of Transportation

\title{
Effects of Stormwater Runoff from Selected Bridge Decks on Conditions of Water, Sediment, and Biological Quality in Receiving Waters in South Carolina, 2013 to 2018
}

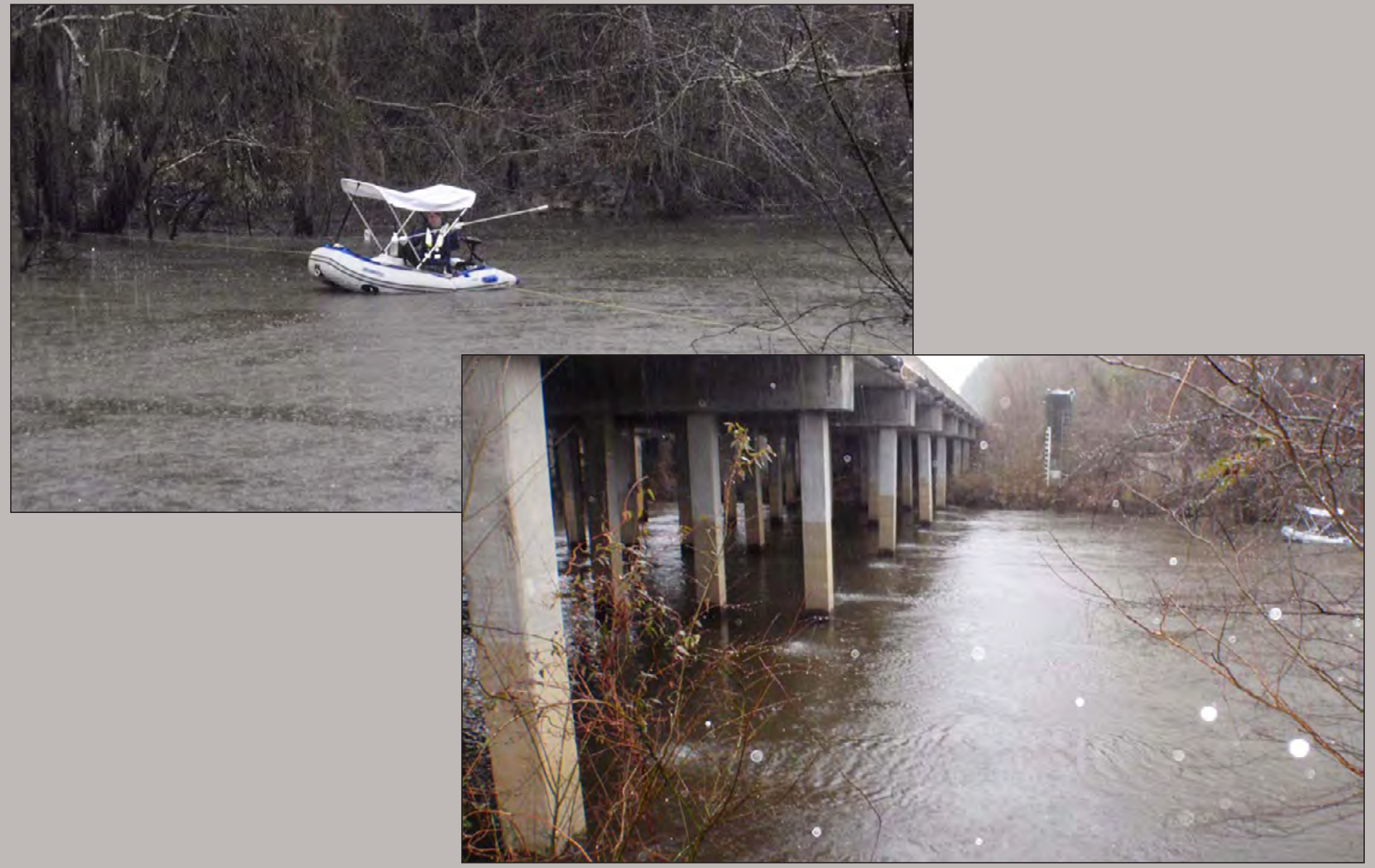

Scientific Investigations Report 2020-5046 


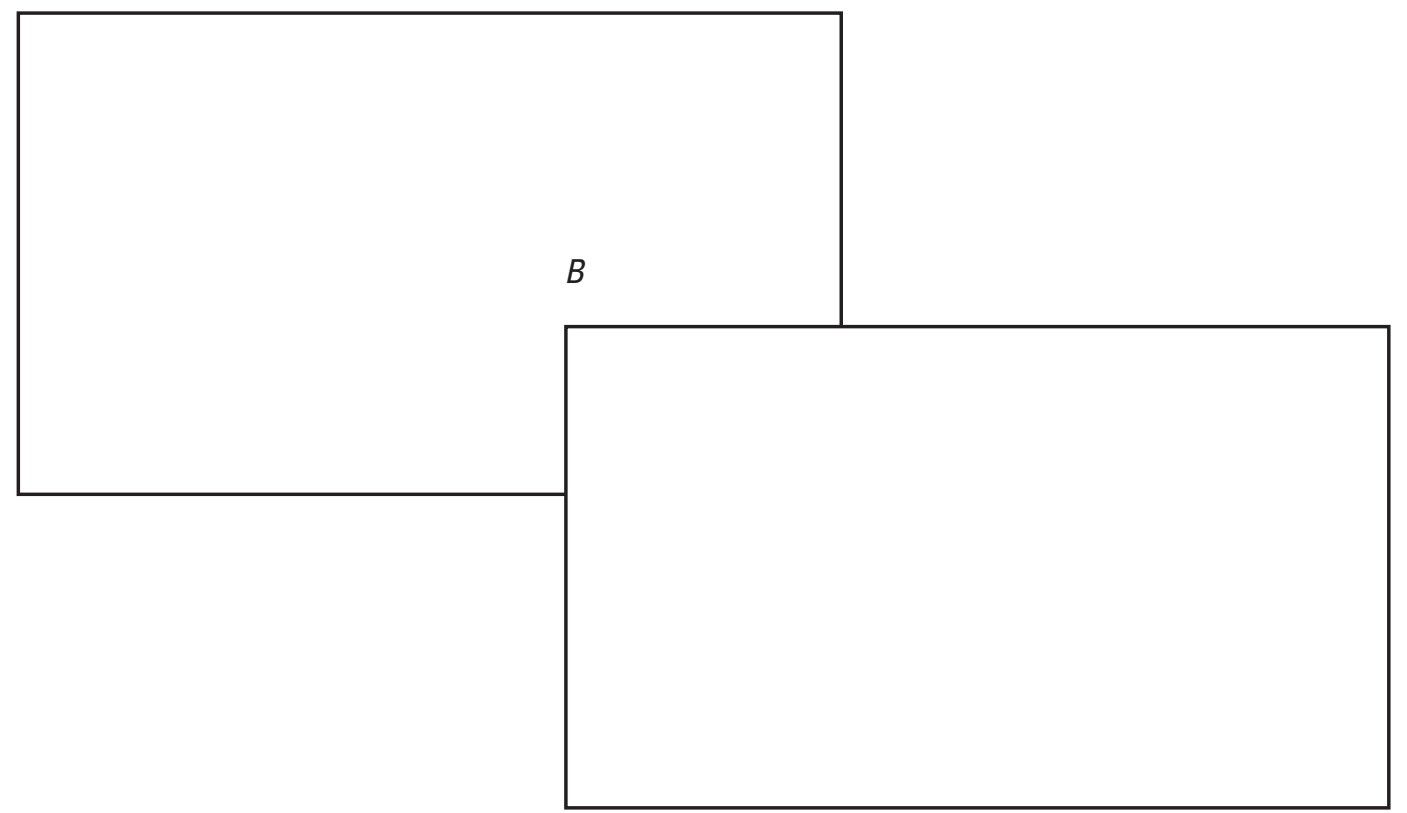

Cover. A, U.S. Geological Survey hydrologist collecting a storm sample at the downstream location on Lynches River near Effingham, South Carolina, using a tag line and inflatable boat; and, $B$, the downstream bridge span on Lynches River near Effingham, South Carolina, with storm runoff entering the river through downspouts, 2014.

Photographs by Fred Falls, U.S. Geological Survey. 


\section{Effects of Stormwater Runoff from Selected Bridge Decks on Conditions of Water, Sediment, and Biological Quality in Receiving Waters in South Carolina, 2013 to 2018}

By Celeste A. Journey, Matthew D. Petkewich, Kevin J. Conlon, Andral W. Caldwell, Jimmy M. Clark, Jeffrey W. Riley, and Paul M. Bradley

Prepared in cooperation with South Carolina Department of Transportation

Scientific Investigations Report 2020-5046 


\title{
U.S. Department of the Interior \\ DAVID BERNHARDT, Secretary
}

\author{
U.S. Geological Survey \\ James F. Reilly II, Director
}

U.S. Geological Survey, Reston, Virginia: 2020

For more information on the USGS - the Federal source for science about the Earth, its natural and living resources, natural hazards, and the environment-visit https://www.usgs.gov or call 1-888-ASK-USGS.

For an overview of USGS information products, including maps, imagery, and publications,

visit https://store.usgs.gov.

Any use of trade, firm, or product names is for descriptive purposes only and does not imply endorsement by the U.S. Government.

Although this information product, for the most part, is in the public domain, it also may contain copyrighted materials as noted in the text. Permission to reproduce copyrighted items must be secured from the copyright owner.

Suggested citation:

Journey, C.A., Petkewich, M.D., Conlon, K.J., Caldwell, A.W., Clark, J.M., Riley, J.W., and Bradley, P.M., 2020, Effects of stormwater runoff from selected bridge decks on conditions of water, sediment, and biological quality in receiving waters in South Carolina, 2013 to 2018: U.S. Geological Survey Scientific Investigations Report 2020-5046, 101 p., https://doi.org/10.3133/sir20205046.

Associated data for this publication:

Romanok, K.M., Journey, C.A., Petkewich, M.K., and Bradley, P.M., 2020, Water-, sediment-, and biological-quality data for waters receiving runoff from five bridges in South Carolina, 2013 to 2018: U.S. Geological Survey data release, https://doi.org/10.5066/P9FXSV2Y.

ISSN 2328-0328 (online) 


\section{Acknowledgments}

The complexity of the investigation required interagency cooperation in addition to individual contributions. The authors thank the staff of the South Carolina Department of Transportation (SCDOT) and, in particular, Chris Beckham, Mitigation Manager; Terry Swygert, Research

Engineer; and Meredith Heaps, Research Program Manager. The authors are grateful for the assistance of Katherine Kolb of the U.S. Geological Survey and also thank the SCDOT and U.S. Geological Survey reviewers for their thoughtful reviews and constructive comments. 


\section{Contents}

Acknowledgments .........................................................................................................................ii

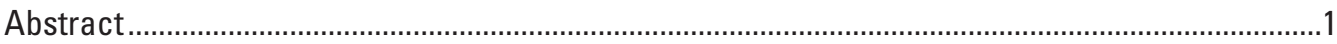

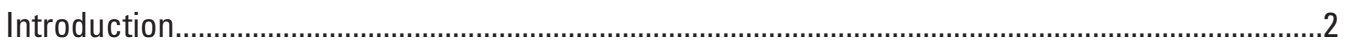

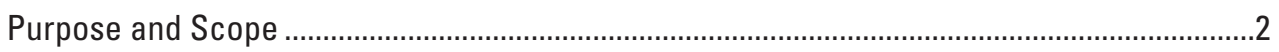

Previous North Carolina Investigation .....................................................................................

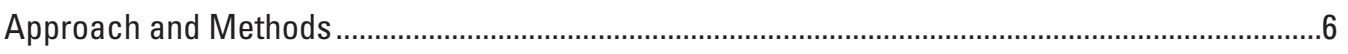

Site Selection, Characterization, and Instrumentation ........................................................6

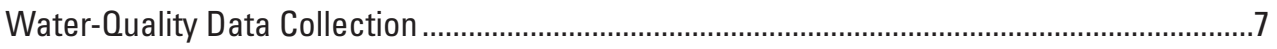

Sediment-Quality Surveys ......................................................................................................11

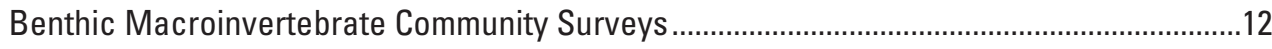

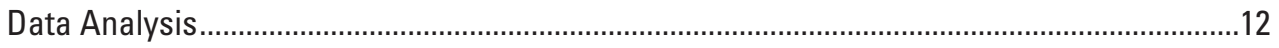

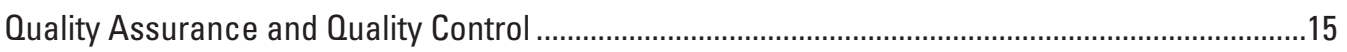

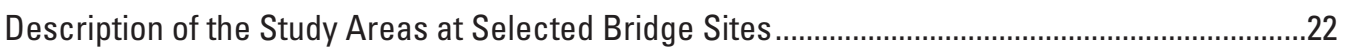

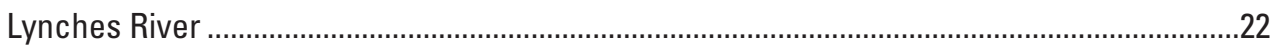

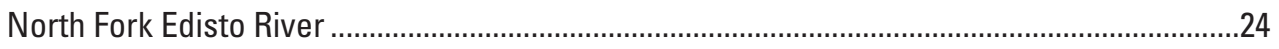

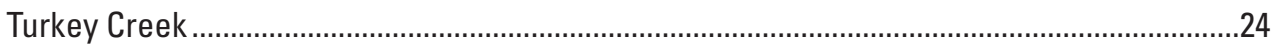

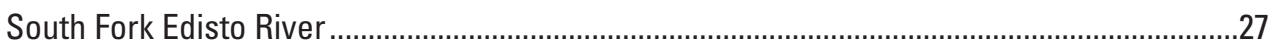

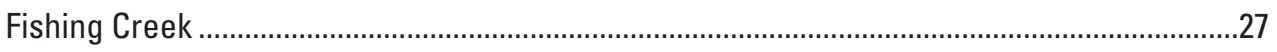

Selected Bridge Site Characteristics ..................................................................................

Hydrologic Characteristics at Selected Bridge Sites .......................................................30

Water-Quality Characteristics at Selected Bridge Sites .........................................................

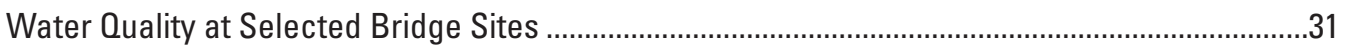

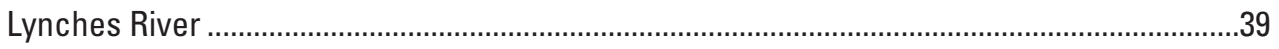

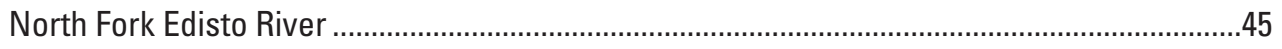

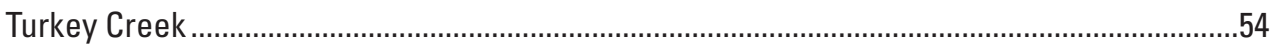

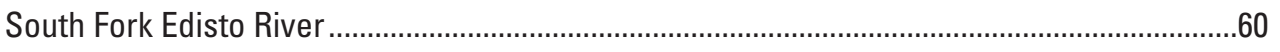

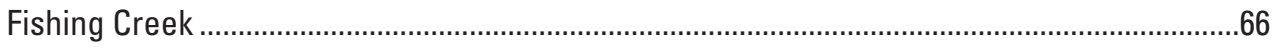

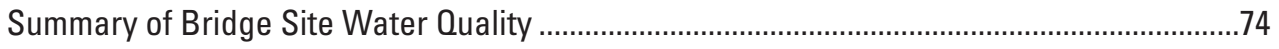

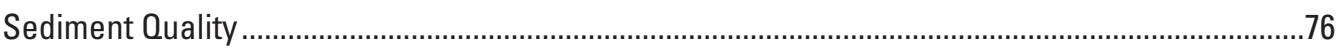

Benthic Macroinvertebrate Assemblages ...........................................................................

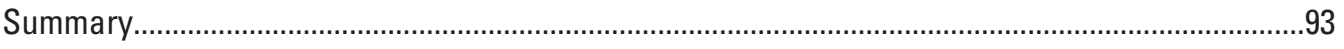

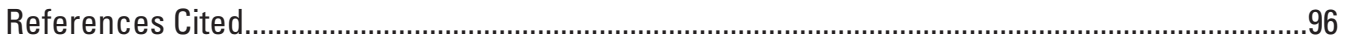

Appendix 1. U.S. Geological Survey National Water Quality

Laboratory methods available for download at https://doi.org/10.3133/sir20205046

Appendix 2. Quality-Assurance and Quality Control Related to stream Water and Sediment Replicate Analysis and

Hydrologic Characterization. available for download at https://doi.org/10.3133/sir20205046

Appendix 3. Water-Quality, Sediment-Quality, and Benthic Macroinvertebrate Data Collected at the Five Selected Bridge Sites in South Carolina, 2013 to 2018. available for download at https://doi.org/10.3133/sir20205046 


\section{Figures}

1. Map showing the five selected bridge sites in relation to the physiographic provinces, South Carolina...

2. Photographs showing, Hester-Dendy artificial substrates prepared for deployment at the downstream transect on South Fork Edisto River near Denmark, South Carolina, and, a U.S. Geological Survey hydrologist evaluating habitat before deployment at the downstream transect at Turkey Creek above Huger, South Carolina

3-7. Maps showing

3. The bridge site on U.S. Highway 52 at the Lynches River at Effingham, South Carolina, streamflow-gaging station.

4. The bridge site on U.S. Highway $601 / 301$ at the North Fork Edisto River at Orangeburg, South Carolina, streamflow-gaging station.

5. The bridge site on South Carolina Highway 41 at the Turkey Creek above Huger, South Carolina, streamflow-gaging station

6. The bridge location on U.S. Highway 321 at the South Fork Edisto River near Denmark, South Carolina, streamflow-gaging station ..

7. The bridge site on South Carolina Highway 5 at the Fishing Creek at Highway 5 below York, South Carolina, streamflow-gaging station.

8. Graphs showing a time series of, daily mean streamflow and instantaneous streamflow during sampling and, total daily precipitation at Lynches River at Effingham, South Carolina, November 2013 to March 2015

9. Boxplots showing field properties in stream water at Lynches River at Effingham, South Carolina, measured at upstream and downstream locations during routine and storm conditions, January 2014 to March 2015

10. Boxplots showing nutrient and suspended-sediment concentrations in stream water at Lynches River at Effingham, South Carolina, measured at upstream and downstream transects during routine and storm conditions, January 2014 to March 2015

11. Boxplots showing total recoverable trace-metal concentrations in stream water at Lynches River at Effingham, South Carolina, measured at upstream and downstream transects during routine and storm conditions, January 2014 to March 2015

12. Boxplot showing Escherichia coli concentrations in stream water at Lynches River at Effingham, South Carolina, measured at upstream and downstream transects during routine and storm conditions, January 2013 to March 2015

13. Graphs showing a time series of, daily mean streamflow and instantaneous streamflow during sampling and, total daily precipitation at North Fork Edisto River at Orangeburg, South Carolina, October 2013 to October 2015.

14-17. Boxplots showing

14. Field properties in stream water at North Fork Edisto River at Orangeburg, South Dakota, measured at upstream and downstream transects during routine and storm conditions, January 2014 to March 2015

15. Nutrient and suspended-sediment concentrations in stream water at North Fork Edisto River at Orangeburg, South Carolina, measured at upstream and downstream transects during routine and storm conditions, January 2014 to March 2015 
16. Total recoverable trace-metal concentrations in stream water at the North Fork Edisto River at Orangeburg, South Carolina, measured at upstream and downstream transects during routine and storm conditions, January 2014 to March 2015.

17. Escherichia coli concentrations in stream water at the North Fork Edisto River at Orangeburg, South Carolina, measured at upstream and downstream transects during routine and storm conditions, January 2013 to March 2015.

18. Graphs showing a time series of, daily mean streamflow and instantaneous streamflow during sampling and, total daily precipitation at Turkey Creek above Huger, South Carolina, from March 2015 to April 2017

19-22. Boxplots showing

19. Field properties in stream water at Turkey Creek above Huger, South Carolina, measured at upstream and downstream transects during routine and storm conditions, April 2015 to March 2017

20. Nutrient and suspended-sediment concentrations in stream water at Turkey River above Huger, South Carolina, measured at upstream and downstream transects during routine and storm conditions, April 2015 to March 2017

21. Total recoverable trace-element concentrations in stream water at Turkey River above Huger, South Carolina, measured at upstream and downstream transects during routine and storm conditions, April 2015 to March 2017

22. Boxplots showing Escherichia coli concentrations in stream water at Turkey Creek above Huger, South Carolina, measured at upstream and downstream transects during routine and storm conditions, March 2015 to April 2017

23. Graphs showing a time series of daily mean streamflow and instantaneous streamflow during sampling and, total daily precipitation at the South Fork Edisto River near Denmark, South Carolina, January 2015 to June 2016

24. Boxplots showing field properties in stream water at South Fork Edisto River near Denmark, South Carolina, measured at upstream and downstream transects during routine and storm conditions, April 2015 to May 2016

25. Boxplots showing nutrient and suspended-sediment concentrations in stream water at the South Fork Edisto River near Denmark, South Carolina, measured at upstream and downstream transects during routine and storm conditions, April 2015 to May 2016

26. Boxplots of total recoverable trace-metal concentrations in stream water at the South Fork Edisto River near Denmark, South Carolina, measured at upstream and downstream transects during routine and storm conditions, April 2015 to May 2016

27. Boxplot showing Escherichia coli concentrations in stream water at South Fork Edisto River near Denmark, South Carolina (U.S. Geological Survey station 02173000), measured at upstream and downstream transects during routine and storm conditions, March 2015 to May 2016.

28. Graphs showing a time series of, daily mean streamflow and instantaneous streamflow during sampling and, total daily precipitation at Fishing Creek at Highway 5 below York, South Carolina, June 2016 to May 2018.

29. Boxplots showing field properties in stream water at Fishing Creek at Highway 5 below York, South Carolina, measured at upstream and downstream transects during routine and storm conditions, July 2016 to April 2018. 
30. Boxplots showing nutrient and suspended-sediment concentrations in stream water at Fishing Creek at Highway 5 below York, South Carolina, measured at upstream and downstream transects during routine and storm conditions, July 2016 to April 2018.

31. Boxplots showing total recoverable trace-metal concentrations in stream water at Fishing Creek at Highway 5 below York, South Carolina, measured at upstream and downstream transects during routine and storm conditions July 2016 to April 2018.

32. Boxplot showing Escherichia coli concentrations in stream water at Fishing Creek at Highway 5 below York, South Carolina, measured at upstream and downstream transects during routine and storm conditions, July 2016 to April 2018.

33. Matrices showing the results of, the permutation one-factor test and pairwise

Wilcoxon test that determined if statistically significant differences in stream water concentrations for routine and storm samples and, the paired one-sided Wilcoxon signed rank test to determine if storm sample constituent concentrations at the downstream transect were greater than at the upstream transect at the five selected bridge sites, South Carolina, 2013 to 2018

34. Graphs showing total metal and polycyclic aromatic hydrocarbon concentrations in bridge-deck sediment at the five selected bridge sites, South Carolina, 2013 to 2016

35. Graph showing metal enrichment ratios, computed from aluminum-normalized metal concentrations, in downstream streambed sediment compared to upstream streambed sediment at the five selected bridge sites, South Carolina.

36. Graph showing polycyclic aromatic hydrocarbon ratios in bridge-deck sediment and streambed sediment upstream and downstream from the five selected bridge sites, South Carolina, 2013 to 2016.

37. Boxplots showing biotic information computed using the benthic macroinvertebrate taxonomic data collected from Hester-Dendy artificial substrates deployed for 8 weeks at transects downstream and upstream from the five selected bridge sites, South Carolina, 2014 to 2016 


\section{Tables}

1. Description of receiving water and the five selected bridge sites that were monitored for water-, sediment-, and biological-quality conditions,

South Carolina, 2013 to 2018

2. Hydrologic and streamflow characteristics of the five selected bridge sites during storm sampling, South Carolina, 2014 to 2018

3. Environmental and quality-control samples collected in receiving water at the five selected bridge sites, South Carolina, 2013 to 2018.

4. South Carolina Department of Health and Environmental Control established human health and freshwater aquatic-life criteria for metals in freshwater and aquatic-health threshold effect and probable effect concentrations for polycyclic aromatic hydrocarbons.

5. Selected polycyclic aromatic hydrocarbon ratios and potential sources of those ratios

6. Relative standard deviations of environmental and replicate samples from stream water and streambed sediments near the five selected bridge sites, South Carolina, 2014 to 2017

7. Percent relative standard deviation of streamflow between transects upstream and downstream from the five selected bridge sites and between gaged and measured streamflow at upstream transect.

8. Relative standard deviation of water-quality data collected along transects upstream and downstream from the five selected bridge sites,

South Carolina, 2013 to 2016

9. Results of the multiple comparison analysis using permutation one-factor test and pairwise Wilcoxon test that determined if statistically significant differences in concentrations for routine samples upstream, storm samples upstream, and storm samples downstream from the bridge at the five selected bridge sites, South Carolina, 2014 to 2018.

9. Results of the multiple comparison analysis using permutation one-factor test and pairwise Wilcoxon test that determined if statistically significant differences in concentrations for routine samples upstream, storm samples upstream, and storm samples downstream from the bridge at the five selected bridge sites, South Carolina, 2014 to 2018.

10. Results of the Wilcoxon one-sided signed rank test to determine if statistically greater constituent concentrations existed at transects downstream compared to upstream from the bridge during storms at the five selected bridge sites, South Carolina, 2014 to 2018

11. Spearman rho correlation results for turbidity, Escherichia coli concentrations, and rainfall characteristics at transects upstream and downstream from the bridge, North Fork Edisto River at Orangeburg, South Carolina, for six storms from 2014 to 2015

12. Spearman rho correlation results for change in turbidity, total organic nitrogen plus ammonia, total nitrogen, and dissolved-oxygen concentrations and rainfall characteristics at transects upstream and downstream from the bridge at Fishing Creek at Highway 5 near York, South Carolina, for five storms from 2016 to 2017.

13. Trace-metal and Escherichia coli concentrations in bridge-deck and streambed sediment at the five selected bridge sites, South Carolina, 2013 to 2016. 
14. Polycyclic aromatic hydrocarbon concentrations in streambed and bridge-deck sediment at the five selected bridge sites, South Carolina, 2013 to 2016.

15. Aluminum-normalized metal concentrations and metal enrichment factors in bridgedeck and streambed sediment collected at the five selected bridge sites, South Carolina, 2013 to 2016.

16. Computed mean metrics for the benthic macroinvertebrate communities collected from Hester-Dendy artificial substrates deployed for 8 weeks at transects downstream and upstream from the five selected bridge sites, South Carolina, 2014 to 2016.............89

17. Results of the analysis of similarity one-factor tests on benthic macroinvertebrate community data collected from Hester-Dendy artificial substrates deployed for 8 weeks at transects downstream and upstream from the five selected bridge sites, South Carolina, 2014 to 2016. 


\section{Conversion Factors}

U.S. customary units to International System of Units

\begin{tabular}{|c|c|c|}
\hline Multiply & By & To obtain \\
\hline \multicolumn{3}{|c|}{ Length } \\
\hline inch (in.) & 2.54 & centimeter $(\mathrm{cm})$ \\
\hline foot (ft) & 0.3048 & meter $(\mathrm{m})$ \\
\hline mile (mi) & 1.609 & kilometer (km) \\
\hline yard (yd) & 0.9144 & meter $(\mathrm{m})$ \\
\hline \multicolumn{3}{|c|}{ Area } \\
\hline acre & 4,047 & square meter $\left(\mathrm{m}^{2}\right)$ \\
\hline acre & 0.4047 & hectare (ha) \\
\hline acre & 0.4047 & square hectometer $\left(\mathrm{hm}^{2}\right)$ \\
\hline acre & 0.004047 & square kilometer $\left(\mathrm{km}^{2}\right)$ \\
\hline square foot $\left(\mathrm{ft}^{2}\right)$ & 929.0 & square centimeter $\left(\mathrm{cm}^{2}\right)$ \\
\hline square foot $\left(\mathrm{ft}^{2}\right)$ & 0.09290 & square meter $\left(\mathrm{m}^{2}\right)$ \\
\hline square inch $\left(\right.$ in $\left.^{2}\right)$ & 6.452 & square centimeter $\left(\mathrm{cm}^{2}\right)$ \\
\hline square mile $\left(\mathrm{mi}^{2}\right)$ & 259.0 & hectare (ha) \\
\hline square mile $\left(\mathrm{mi}^{2}\right)$ & 2.590 & square kilometer $\left(\mathrm{km}^{2}\right)$ \\
\hline \multicolumn{3}{|c|}{ Volume } \\
\hline gallon (gal) & 3.785 & liter (L) \\
\hline gallon (gal) & 0.003785 & cubic meter $\left(\mathrm{m}^{3}\right)$ \\
\hline gallon (gal) & 3.785 & cubic decimeter $\left(\mathrm{dm}^{3}\right)$ \\
\hline million gallons (Mgal) & 3,785 & cubic meter $\left(\mathrm{m}^{3}\right)$ \\
\hline cubic foot $\left(\mathrm{ft}^{3}\right)$ & 0.02832 & cubic meter $\left(\mathrm{m}^{3}\right)$ \\
\hline cubic yard $\left(\mathrm{yd}^{3}\right)$ & 0.7646 & cubic meter $\left(\mathrm{m}^{3}\right)$ \\
\hline cubic mile $\left(\mathrm{mi}^{3}\right)$ & 4.168 & cubic kilometer $\left(\mathrm{km}^{3}\right)$ \\
\hline acre-foot (acre-ft) & 1,233 & cubic meter $\left(\mathrm{m}^{3}\right)$ \\
\hline \multicolumn{3}{|c|}{ Flow rate } \\
\hline acre-foot per day (acre-ft/d) & 0.01427 & cubic meter per second $\left(\mathrm{m}^{3} / \mathrm{s}\right)$ \\
\hline cubic foot per second $\left(\mathrm{ft}^{3} / \mathrm{s}\right)$ & 0.02832 & cubic meter per second $\left(\mathrm{m}^{3} / \mathrm{s}\right)$ \\
\hline $\begin{array}{l}\text { cubic foot per second per square mile } \\
\qquad\left(\left[\mathrm{ft}^{3} / \mathrm{s}\right] / \mathrm{mi}^{2}\right)\end{array}$ & 0.01093 & $\begin{array}{l}\text { cubic meter per second per square } \\
\text { kilometer }\left(\left[\mathrm{m}^{3} / \mathrm{s}\right] / \mathrm{km}^{2}\right)\end{array}$ \\
\hline cubic foot per day $\left(\mathrm{ft}^{3} / \mathrm{d}\right)$ & 0.02832 & cubic meter per day $\left(\mathrm{m}^{3} / \mathrm{d}\right)$ \\
\hline gallon per minute (gal/min) & 0.06309 & liter per second $(\mathrm{L} / \mathrm{s})$ \\
\hline gallon per day (gal/d) & 0.003785 & cubic meter per day $\left(\mathrm{m}^{3} / \mathrm{d}\right)$ \\
\hline gallon per day per square mile $\left([\mathrm{gal} / \mathrm{d}] / \mathrm{mi}^{2}\right)$ & 0.001461 & cubic meter per day per square \\
\hline & & kilometer $\left.\left(\left[\mathrm{m}^{3} / \mathrm{d}\right)\right] / \mathrm{km}^{2}\right)$ \\
\hline million gallons per day (Mgal/d) & 0.04381 & cubic meter per second $\left(\mathrm{m}^{3} / \mathrm{s}\right)$ \\
\hline million gallons per day per square mile & 1,461 & cubic meter per day per square \\
\hline$\left([\mathrm{Mgal} / \mathrm{d}] / \mathrm{mi}^{2}\right)$ & & kilometer $\left(\left[\mathrm{m}^{3} / \mathrm{d}\right] / \mathrm{km}^{2}\right)$ \\
\hline \multicolumn{3}{|c|}{ Mass } \\
\hline pound, avoirdupois (lb) & 0.4536 & kilogram $(\mathrm{kg})$ \\
\hline ton, short $(2,000 \mathrm{lb})$ & 0.9072 & metric ton $(\mathrm{t})$ \\
\hline \multicolumn{3}{|c|}{ Pressure } \\
\hline inch of mercury at $60^{\circ} \mathrm{F}$ (in $\mathrm{Hg}$ ) & 3.377 & kilopascal (kPa) \\
\hline
\end{tabular}


Temperature in degrees Celsius $\left({ }^{\circ} \mathrm{C}\right)$ may be converted to degrees Fahrenheit $\left({ }^{\circ} \mathrm{F}\right)$ as follows: ${ }^{\circ} \mathrm{F}=\left(1.8 \times{ }^{\circ} \mathrm{C}\right)+32$

\section{Supplemental Information}

Specific conductance is given in microsiemens per centimeter at 25 degrees Celsius $\left(\mu \mathrm{S} / \mathrm{cm}\right.$ at $\left.25^{\circ} \mathrm{C}\right)$.

Concentrations of chemical constituents in water are given in either milligrams per liter (mg/L) or micrograms per liter $(\mu \mathrm{g} / \mathrm{L})$. Concentrations of chemical constituents in sediment are given in either micrograms per kilogram $(\mu \mathrm{g} / \mathrm{kg})$ or milligrams per kilogram $(\mathrm{mg} / \mathrm{kg})$.

Concentrations of microbiological constituents in water are given in most probable number per 100 milliliters (MPN/100 mL).

\section{Abbreviations}

$\begin{array}{ll}\text { AADT } & \text { annual average daily traffic } \\ \text { ANOSIM } & \text { analysis of similarity } \\ \text { CCC } & \text { criterion chronic concentration } \\ \text { CMC } & \text { criterion maximum concentration } \\ \text { DO } & \text { dissolved oxygen } \\ \text { E } & \text { estimated } \\ \text { E. coli } & \text { Escherichia coli } \\ \text { EPT } & \text { Ephemeroptera, Plecoptera, and Trichoptera spp } \\ \text { ER } & \text { enrichment ratio } \\ \text { EWI } & \text { equal width increment } \\ \text { FNU } & \text { formazin nephelomtric unit } \\ \text { HMW } & \text { high molecular weight } \\ \text { LMW } & \text { low molecular weight } \\ \text { LRL } & \text { laboratory reporting level } \\ \text { NO }{ }_{3}+N_{2}{ }_{2} & \text { nitrate plus nitrite } \\ \text { NTU } & \text { nephelometric turbidity unit } \\ \text { NWIS } & \text { National Water Information System } \\ \text { NWOL } & \text { National Water Quality Laboratory } \\ \text { PAH } & \text { polycylic aromatic hydrocarbon } \\ \text { PEC } & \text { probable effect concentration } \\ \text { RSD } & \text { relative standard deviation }\end{array}$




$\begin{array}{ll}\text { SB } & \text { medium code for streambed sediment } \\ \text { SC } & \text { specific conductance } \\ \text { SCDHEC } & \text { South Carolina Department of Health and Environmental Control } \\ \text { SCDOT } & \text { South Carolina Department of Transportation } \\ \text { SSC } & \text { suspended-sediment concentration } \\ \text { SU } & \text { standard units } \\ \text { SVOC } & \text { semivolatile organic compounds } \\ \text { TEC } & \text { threshold effect concentration } \\ \text { TKN } & \text { total Kjeldahl nitrogen (ammonia plus total organic nitrogen) } \\ \text { TN } & \text { total nitrogen } \\ \text { TP } & \text { total phosphorus } \\ \text { USDA } & \text { U.S. Department of Agriculture } \\ \text { USGS } & \text { U.S. Geological Survey } \\ \text { WS } & \text { medium code for surface-water sample }\end{array}$




\title{
Effects of Stormwater Runoff from Selected Bridge Decks on Conditions of Water, Sediment, and Biological Quality in Receiving Waters in South Carolina, 2013 to 2018
}

\author{
By Celeste A. Journey, Matthew D. Petkewich, Kevin J. Conlon, Andral W. Caldwell, Jimmy M. Clark, \\ Jeffrey W. Riley and Paul M. Bradley
}

Abstract

The U.S. Geological Survey, in cooperation with the South Carolina Department of Transportation, investigated the effects of stormwater runoff from bridge decks on stream water quality conditions in South Carolina. The investigation assessed 5 bridges in 3 physiographic provinces in South Carolina (Piedmont, Upper Coastal Plain, and Lower Coast Plain) that had a range of bridge, traffic, and hydrologic characteristics. The five selected South Carolina bridge sites (coincident with U.S. Geological Survey stations) and corresponding highways were Lynches River at Effingham (station 02132000; U.S. Highway 52), North Fork Edisto River at Orangeburg (station 02173500; U.S. Highway 301), Turkey Creek above Huger (station 02172035; South Carolina Highway 41), South Fork Edisto River near Denmark (station 02173000; U.S. Highway 321), and Fishing Creek at Highway 5 below York (station 021473415; South Carolina Highway 5). Bridge decks at the selected sites used open chutes, scuppers, and downspouts to drain stormwater directly into the receiving water at evenly spaced intervals.

Stream water, sediment, and biological samples were collected and analyzed for a variety of constituents to evaluate the stream conditions for this study. Five to six stream samples were collected at transects upstream and downstream from each selected bridge site using the equal-width-increment technique during observable stormwater runoff. Routine samples of the receiving waters were collected 12 to 14 times at the upstream transect during nonstorm conditions. Samples were analyzed for physical properties, suspended sediment, nutrients, major ions, trace metals, polycyclic aromatic hydrocarbons, and Escherichia coli. Bridge-deck sediment and streambed sediment at upstream and downstream transects were collected once at each bridge site and analyzed for metals and semivolatile organic compounds that include polycyclic aromatic hydrocarbons. Benthic macroinvertebrate community surveys were conducted once using Hester-Dendy multiplate artificial substrate samplers deployed at multiple upstream and downstream transects concurrently.
Statistical analysis of the water-quality data determined that stormwater runoff from bridges did not significantly degrade physical properties, nor nutrient, trace-metal, Escherichia coli, and suspended-sediment concentrations at the selected sites beyond the variability at the upstream transect (no bridge influence) during the study period. During storm sampling at the bridge sites, water-quality conditions were statistically similar upstream and downstream from each bridge, except for greater turbidity, total nitrogen, and total organic nitrogen plus ammonia concentrations found downstream from the bridge site on Fishing Creek; higher total chromium concentrations detected downstream from the bridge site on Turkey Creek; and increased Escherichia coli concentrations found downstream from the bridge site on the North Fork Edisto River. Total recoverable lead, cadmium, and copper concentrations were the only trace metals that periodically exceeded the South Carolina Department of Health and Environmental Control freshwater aquatic-life criteria at some bridge sites (lead, copper, and cadmium in Turkey Creek; cadmium and lead in Fishing Creek; lead in the South Fork Edisto River and Lynches River), but the exceedances occurred more frequently during routine sampling upstream from the bridge sites than during storm sampling at upstream and downstream transects. In general, stormwater runoff from the bridge decks did not seem to be the major source of metal enrichment in receiving waters during the study period. North Fork and South Fork Edisto Rivers and Turkey Creek had only one storm sample that exceeded South Carolina Department of Health and Environmental Control recreational criterion for Escherichia coli at both the upstream and downstream locations, while Fishing Creek had more frequent exceedances. Polycyclic aromatic hydrocarbons were detected infrequently in the stream samples.

In general, sediment trace-metal concentrations were below the threshold and probable effect concentration at all bridge sites, except for the chromium concentration (45.1 milligrams per kilogram) detected upstream from the bridge site on Fishing Creek that exceeded the threshold effect concentration of 43.4 milligrams per kilogram. Based on enrichment ratios less than 1.5 , bridge-deck runoff did 
not seem to be affecting trace-metal accumulation in the streambed sediment downstream from the bridge sites, except for lead at the bridge site on the Lynches River and manganese at the bridge site on Fishing Creek.

Individual polycyclic aromatic compound concentrations and the sum of 18 compounds did not exceed any threshold and probable effect concentrations, indicating polycyclic aromatic hydrocarbon concentrations in the streambed sediment at downstream and upstream transects were not likely to affect the health of benthic macroinvertebrate communities. Although the cumulative polycyclic aromatic hydrocarbon concentrations in downstream sediment at the sites on Turkey and Fishing Creeks were well below the threshold effect concentration of 1,610 micrograms per kilogram, the 3 - to 100 -fold increase in downstream concentrations indicated a strong probability of a bridge-deck runoff source.

Overall, benthic macroinvertebrate community health downstream from the bridge sites did not seem to be affected by bridge-deck runoff based on several multivariate analyses that indicated statistically similar benthic macroinvertebrate communities at upstream and downstream transects. Of the five bridge sites in this study, the site on Turkey Creek seemed to have the least healthy benthic macroinvertebrate communities because of the lowest Ephemeroptera, Plecoptera, and Trichoptera spp. (mayflies, stoneflies, and caddisflies, respectively) taxa, species richness, and diversity; and the highest biotic indices, indicative of poorer ecological health, at upstream and downstream transects. This ecological finding was not unexpected because of seasonal periods of negligible flow when dissolved-oxygen concentrations fell below 4 milligrams per liter during the study period. Of the five bridge sites in this study, the site on the South Fork Edisto River seemed to have healthier benthic macroinvertebrate communities because of the greater mean Ephemeroptera, Plecoptera, and Trichoptera spp. taxa; and lower mean biotic indices at upstream and downstream transects.

\section{Introduction}

In South Carolina, highway runoff during storms may be treated by structural or nonstructural control systems (including collection systems, dry ponds, retention basins, constructed wetlands, and other practices) as a form of best management practices (National Academies of Sciences, Engineering, and Medicine, 2014; Winston and others, 2015). However, in some locations of South Carolina, stormwater may enter receiving waters without treatment, including from bridge decks that are not readily addressed by traditional best management practices. Many South Carolina bridges drain stormwater through evenly spaced scuppers, downspouts, and other openings on the bridge deck directly into receiving waters. The quality of the stormwater runoff may be driven by the daily traffic volume, bridge-deck area, and antecedent conditions, as some previous studies have alluded to, and (or) by atmospheric deposition from surrounding industry (Wagner and others, 2011; National Academies of Sciences, Engineering, and Medicine, 2014; Winston and others, 2015). Even though numerous studies have been conducted to analyze the effects of stormwater from highways and, to a lesser extent, from bridge decks to receiving waters nationally, no specific studies have been conducted in South Carolina at the writing of this report (Irwin and Losey, 1978; Wanielista, and others, 1980; McKenzie and Irwin, 1983; Yousef and others, 1984; Harned, 1987; Driscoll and others, 1988; Zellhoefer, 1989; Stoker, 1996; Marsalek and others, 1997; Dupuis, 2002; Smith, 2002; Granato, 2003; Malina and others, 2005; Pitt and Maestre, 2005; Smith and Granato, 2010; Wagner and others, 2011).

Previous stormwater research indicated relatively high concentrations of a variety of constituents such as nutrients, solids, pesticides, trace metals, and polycyclic aromatic hydrocarbons (PAHs) in stormwater runoff from bridge decks (hereafter "bridge-deck runoff") (McKenzie and Irwin, 1983; Driscoll and others, 1988; Marsalek and others, 1997; Dupuis, 2002; Malina and others, 2005; Pitt and Maestre, 2005; Wagner and others, 2011). A recent U.S. Geological Survey (USGS) investigation in North Carolina characterized the quality of stormwater runoff from more than 15 bridge decks with installed collection systems (Wagner and others, 2011; Winston and others, 2015); however, most bridges in South Carolina do not have stormwater-collection systems.

The South Carolina Department of Transportation (SCDOT) requested the USGS design and implement a study to evaluate the effects of stormwater runoff from bridge decks on water-, sediment-, and biological-quality conditions on receiving waters in South Carolina. The bridge decks that were considered for study in South Carolina used open chutes, scuppers, and downspouts to drain stormwater directly into the receiving water at evenly spaced intervals rather than into collection basins or other structural stormwater-collection systems. Because the lack of collection systems prevented the direct sampling, analysis, and characterization of the quality of stormwater from bridge decks in South Carolina, stormwater quality from the bridge deck was not monitored directly. Instead, the focus of this investigation was to provide the SCDOT with data needed to adequately assess how the direct release of stormwater to receiving water affects receiving-water quality. The South Carolina investigation adopted approaches similar to recent research in North Carolina, where possible, to allow for a more regional scope to the problem; however, deviations from the North Carolina research were required to address the selected bridge decks in South Carolina.

\section{Purpose and Scope}

The purpose of this report is to describe the findings from the investigation that monitored 5 bridges in 3 physiographic provinces (Piedmont, Upper Coastal Plain, and Lower Coast Plain) in South Carolina (fig. 1; table 1). From 2013 
to 2018, data were collected and used (1) to compare to existing aquatic-life criteria, where available, during storm and nonstorm conditions and (2) to assess the downstream changes in receiving-water-quality conditions during periods of observable stormwater runoff at selected bridge decks. Additionally, comparisons of sediment-quality conditions and benthic macroinvertebrate community structure at transects upstream and downstream from selected bridge decks were used to assess integrated bridge-deck runoff effects on receiving water. The approach, methods, and data from this investigation are not suitable for assessment of mean concentrations for bridge-deck runoff or National Pollutant Discharge Elimination System permit requirements. The information collected was designed to help estimate changes in water quality in receiving waters at bridge crossings with similar characteristics.

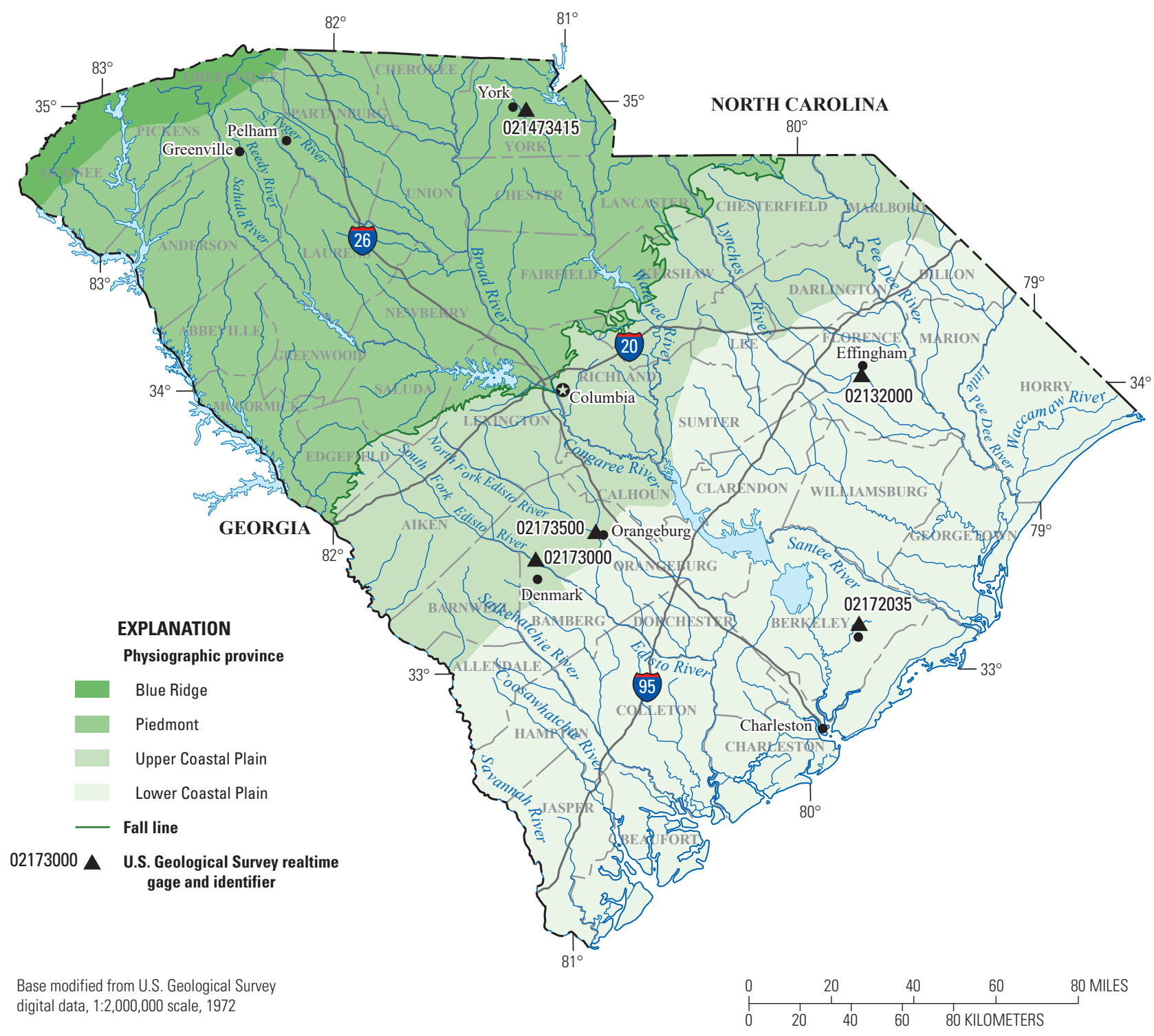

Figure 1. Map showing the five selected bridge sites (U.S. Geological Survey stations $02132000,02173500,02172035,02173000$, and 021473415 ) in relation to the physiographic provinces, South Carolina. 
Table 1. Description of receiving water and the five selected bridge sites that were monitored for water-, sediment-, and biological-quality conditions, South Carolina, 2013 to 2018.

[Latitude and longitude are given in degrees ( $\left.{ }^{\circ}\right)$, minutes ('), and seconds ("). USGS, U.S. Geological Survey; ID, identifier; SCDHEC, South Carolina Department of Health and Environmental Control; mi², square mile; AADT, annual average daily traffic; WY, water year; $\mathrm{ft}^{3} / \mathrm{s}$, cubic foot per second; ft, foot; s/ft, second per foot; Hwy, highway; DO, dissolved oxygen; BOD5, 5-day biochemical oxygen demand; FIB, fecal indicator bacteria; Hg-fish, mercury as a fish consumption advisory; S.C., South Carolina]

\begin{tabular}{|c|c|c|c|c|c|c|c|c|c|c|c|c|}
\hline \multirow{2}{*}{$\begin{array}{l}\text { USGS station } \\
\text { number }^{1} \\
\text { (fig. 1) }\end{array}$} & \multirow[b]{2}{*}{ USGS station name ${ }^{1}$} & \multirow[b]{2}{*}{ Site ID } & \multirow[b]{2}{*}{$\begin{array}{c}\text { Physiographic } \\
\text { province }\end{array}$} & \multirow[b]{2}{*}{ Road } & \multirow[b]{2}{*}{$\begin{array}{l}\text { Existing SCDHEC } \\
\text { impairment or } \\
\text { concern }\end{array}$} & \multirow[b]{2}{*}{$\begin{array}{l}\text { Drainage } \\
\text { area }\left(\mathrm{mi}^{2}\right)\end{array}$} & \multirow[b]{2}{*}{ Latitude } & \multirow[b]{2}{*}{ Longitude } & \multirow{2}{*}{$\begin{array}{c}\text { AADT } \\
\text { during } \\
\text { sampling } \\
\text { period } \\
\text { (vehicles } \\
\text { per day) }\end{array}$} & \multicolumn{2}{|c|}{ Sampling period } & \multirow[b]{2}{*}{$\begin{array}{l}\text { Period } \\
\text { of record } \\
(\mathrm{WY})^{2}\end{array}$} \\
\hline & & & & & & & & & & Start & End & \\
\hline 02132000 & $\begin{array}{l}\text { Lynches River at Effingham, } \\
\text { South Carolina }\end{array}$ & Lynches & $\begin{array}{l}\text { Lower Coastal } \\
\text { Plain }\end{array}$ & U.S. Hwy 52 & $\begin{array}{c}\text { pH, DO, BOD5, } \\
\text { FIB, Hg-fish }\end{array}$ & 1,030 & $34^{\circ} 03^{\prime} 05^{\prime \prime}$ & $79^{\circ} 45^{\prime} 15^{\prime \prime}$ & $\begin{array}{c}14,500 \text { to } \\
18,400\end{array}$ & $\begin{array}{c}\text { October } \\
2013\end{array}$ & $\begin{array}{l}\text { March } \\
2015\end{array}$ & $\begin{array}{l}1930 \text { to } \\
2018\end{array}$ \\
\hline 02173500 & $\begin{array}{l}\text { North Fork Edisto River } \\
\text { at Orangeburg, South } \\
\text { Carolina }\end{array}$ & NFEdisto & $\begin{array}{l}\text { Upper Coastal } \\
\text { Plain }\end{array}$ & $\begin{array}{l}\text { U.S. Hwy } \\
301 / 601\end{array}$ & pH, BOD5, Hg-fish & 683 & $33^{\circ} 29^{\prime} 00^{\prime \prime}$ & $80^{\circ} 52^{\prime} 25^{\prime \prime}$ & $\begin{array}{l}21,000 \text { to } \\
24,300\end{array}$ & $\begin{array}{r}\text { October } \\
2013\end{array}$ & $\begin{array}{l}\text { March } \\
2015\end{array}$ & $\begin{array}{l}1939 \text { to } \\
2018\end{array}$ \\
\hline 02172035 & $\begin{array}{l}\text { Turkey Creek above Huger, } \\
\text { South Carolina }\end{array}$ & Turkey & $\begin{array}{l}\text { Lower Coastal } \\
\quad \text { Plain }\end{array}$ & S.C. Hwy 41 & None & 22.7 & $33^{\circ} 07^{\prime} 53^{\prime \prime}$ & $79^{\circ} 47^{\prime} 02^{\prime \prime}$ & $\begin{array}{c}2,600 \text { to } \\
2,700\end{array}$ & $\begin{array}{l}\text { April } \\
2015\end{array}$ & $\begin{array}{l}\text { March } \\
2017\end{array}$ & $\begin{array}{l}2005 \text { to } \\
2018\end{array}$ \\
\hline 02173000 & $\begin{array}{l}\text { South Fork Edisto River near } \\
\text { Denmark, South Carolina }\end{array}$ & SFEdisto & $\begin{array}{l}\text { Upper Coastal } \\
\text { Plain }\end{array}$ & $\begin{array}{l}\text { U.S. Hwy } \\
321\end{array}$ & pH, BOD5, Hg-fish & 720 & $33^{\circ} 23^{\prime} 35^{\prime \prime}$ & $81^{\circ} 08^{\prime} 00^{\prime \prime}$ & $\begin{array}{c}2,800 \text { to } \\
3,200\end{array}$ & $\begin{array}{l}\text { March } \\
2015\end{array}$ & $\begin{array}{l}\text { May } \\
2016\end{array}$ & $\begin{array}{l}1931 \text { to } \\
2018\end{array}$ \\
\hline 021473415 & $\begin{array}{l}\text { Fishing Creek at Highway } 5 \\
\text { below York, South Carolina }\end{array}$ & Fishing & Piedmont & S.C. Hwy 5 & $\begin{array}{l}\text { Fecal coliform } \\
\text { bacteria }\end{array}$ & 16.7 & $34^{\circ} 58^{\prime} 30^{\prime \prime}$ & $81^{\circ} 10^{\prime} 48^{\prime \prime}$ & $\begin{array}{l}8,700 \text { to } \\
9,000\end{array}$ & May 2016 & $\begin{array}{l}\text { March } \\
2018\end{array}$ & $\begin{array}{l}2008 \text { to } \\
2018\end{array}$ \\
\hline
\end{tabular}


Table 1. Description of receiving water and the five selected bridge sites that were monitored for water-, sediment-, and biological-quality conditions, South Carolina, 2013 to 2018.-Continued

[Latitude and longitude are given in degrees ( ${ }^{\circ}$ ), minutes ('), and seconds ("). USGS, U.S. Geological Survey; ID, identifier; SCDHEC, South Carolina Department of Health and Environmental Control; mi², square mile; AADT, annual average daily traffic; WY, water year; ft ${ }^{3} / \mathrm{s}$, cubic foot per second; ft, foot; s/ft, second per foot; Hwy, highway; DO, dissolved oxygen; BOD5, 5-day biochemical oxygen demand; FIB, fecal indicator bacteria; Hg-fish, mercury as a fish consumption advisory; S.C., South Carolina]

\begin{tabular}{|c|c|c|c|c|c|c|c|c|c|c|c|}
\hline \multirow{2}{*}{$\begin{array}{c}\text { USGS station } \\
\text { number } \\
\text { (fig. 1) }\end{array}$} & \multirow[b]{2}{*}{ USGS station name ${ }^{1}$} & \multirow[b]{2}{*}{ Site ID } & \multicolumn{5}{|c|}{ Daily mean streamflow statistics for period of record ( $\left.\mathrm{ft}^{3} / \mathrm{s}\right)$} & \multirow[b]{2}{*}{$\begin{array}{l}\text { Total } \\
\text { WYs }\end{array}$} & \multirow{2}{*}{$\begin{array}{c}\text { Bridge } \\
\text { length } \\
\text { (ft) }\end{array}$} & \multirow{2}{*}{$\begin{array}{c}\text { Bridge } \\
\text { width } \\
\text { (ft) }\end{array}$} & \multirow[b]{2}{*}{$\begin{array}{l}\text { Ratio of bridge deck area } \\
\text { to mean streamflow }(\mathrm{s} / \mathrm{ft})\end{array}$} \\
\hline & & & Minimum & 25th percentile & Mean & $\begin{array}{c}\text { 75th } \\
\text { percentile }\end{array}$ & Maximum & & & & \\
\hline 02132000 & $\begin{array}{l}\text { Lynches River at Effingham, } \\
\text { South Carolina }\end{array}$ & Lynches & 69.4 & 356 & 649 & 1,240 & 24,500 & 89 & 660 & 39.5 & 43 \\
\hline 02173500 & $\begin{array}{l}\text { North Fork Edisto River at } \\
\text { Orangeburg, South Carolina }\end{array}$ & NFEdisto & 113 & 442 & 718 & 856 & 8,850 & 80 & 291 & 54 & 25 \\
\hline 02172035 & $\begin{array}{l}\text { Turkey Creek above Huger, } \\
\text { South Carolina }\end{array}$ & Turkey & 0 & 0.06 & 21.8 & 13.7 & 5,500 & 13 & 120 & 44 & 926 \\
\hline 02173000 & $\begin{array}{l}\text { South Fork Edisto River near } \\
\text { Denmark, South Carolina }\end{array}$ & SFEdisto & 110 & 417 & 712 & 856 & 12,700 & 77 & 394 & 26 & 18 \\
\hline 021473415 & $\begin{array}{l}\text { Fishing Creek at Highway } 5 \text { below } \\
\text { York, South Carolina }\end{array}$ & Fishing & 0.01 & 1.38 & 12.3 & 8.09 & 2,910 & 11 & 96 & 42 & 640 \\
\hline
\end{tabular}

${ }^{1}$ Station numbers and names are from the USGS National Water Information System database (USGS, 2016).

${ }^{2} \mathrm{~A}$ water year is the period from October 1 to September 30 of the following year and is designated by the year in which it ends. 


\section{Previous North Carolina Investigation}

From 2009 to 2011, the USGS, in cooperation with the North Carolina Department of Transportation, conducted an investigation to (1) quantify the constituents in stormwater runoff from bridge decks across the State, (2) evaluate the treatment practices of collection systems that can be used to reduce constituent loadings to surface waters from bridges, and (3) determine the effectiveness of the evaluated treatment practices (Wagner and others, 2011).

In North Carolina, the USGS measured (1) stormwater runoff from 15 bridge-deck sites with existing stormwatercollection systems to quantify constituent concentrations and loads, (2) stream-water-quality conditions at upstream locations at a subset of 4 bridge-deck sites to determine stream loads of targeted constituents, and (3) streambed-sediment chemistry upstream and downstream from 30 bridges across North Carolina (Wagner and others, 2011). The bridges selected for study had differing sizes, ecoregions, and land-use characteristics, and a range of annual average daily traffic (AADT). The 28 pollutants of concern included metals, nutrients, $\mathrm{pH}$, suspended-solids concentration, PAHs, and other organic compounds.

The analysis of the streambed-sediment quality revealed no obvious patterns of downstream increases in inorganic analytes and total organic carbon at the sampled bridge sites. Downstream enrichment of streambed sediment with semivolatile organic compounds (including PAHs) was not consistent, even at the bituminous (asphalt) bridges, and patterns related to urban versus rural bridges or to traffic volume were not obvious. One major finding in the North Carolina Department of Transportation study was that the bridge-deck runoff concentrations at all sites were similar to those measured in the receiving waters at the four stream sampling sites, except for dissolved copper and zinc, total recoverable nickel, and $\mathrm{PAH}$ concentrations, which were consistently higher in bridge-deck runoff. Comparisons of bridge-deck and stream loads indicated that all bridge-deck runoff loads were lower (and generally orders of magnitude lower) than the stream loads for all pollutants of concern. However, no direct measurement of the receiving water downstream from the bridge during rain was made to further evaluate the effects of stormwater runoff from the bridge deck.

\section{Approach and Methods}

The approach and methods that are described in this report include (1) site selection, characterization, and instrumentation; (2) water-, sediment-, and biological-quality data collection; and (3) data analysis. Site selection and characterization began in July 2013. Data collection attempted to target two bridge sites per physiographic province per calendar year, but difficulty in capturing adequate storms required the effort to be extended beyond the 1-year period during the overall data-collection period of October 2013 through April 2018. Because bridge decks with stormwatercollection systems, which would have allowed automated instrumentation to directly measure water-quantity and waterquality conditions of bridge-deck runoff, were not available for study in South Carolina, data collection focused on capturing the evenly distributed release of stormwater runoff from bridge-deck open chutes, scuppers, and downspouts by assessing stream water-quality conditions at transects upstream (not affected by bridge-deck runoff) and downstream (affected by bridge-deck runoff) from selected bridge sites. Depth-integrated, equal-width-increment (EWI) techniques were used to collect water samples instead of a point or grab sample because EWI samples represent the entire stream cross section of the receiving water at a transect (U.S. Geological Survey, variously dated). For each storm, the quantity of bridge-deck runoff was estimated using existing bridge-deck runoff equations based on rainfall amount and intensity (Jens, 1979; Morgali and Linsley, 1965).

Data analysis included statistical assessments of selected constituent concentrations from upstream and downstream transects at each of the bridge-deck sites, and statistical comparisons of streambed-sediment quality and benthic macroinvertebrate community structure upstream and downstream from bridges.

\section{Site Selection, Characterization, and Instrumentation}

Candidate bridge sites were assessed based on physiographic province, existence of impaired water designation by the South Carolina Department of Health and Environmental Control (SCDHEC), presence of existing streamflow-gaging stations, bridge impervious deck area, bridge-deck drainage type, and AADT counts provided by the SCDOT and by on-site reconnaissance (South Carolina Department of Transportation, 2018). Bridge decks were characterized by computing bridge-deck area; estimating the stormwater runoff from the bridge deck at different rainfall amounts and intensities; and comparing estimated bridge-deck runoff to annual streamflow statistics at long-term streamflow-gaging stations (table 2).

To characterize the peak runoff from the bridge deck, the Rational Method (Jens, 1979) was used to convert rainfall intensity for different storm frequencies to runoff according to this formula:

$$
Q=C i A,
$$

where

$Q \quad$ is the peak runoff rate, in cubic feet per second; $C \quad$ is the coefficient of runoff, which is dimensionless and is considered to be between 0.9 and 1.0 for bridge decks when the bridge-deck pavement is the sole contributing surface for runoff; 
$i \quad$ is the average rainfall intensity, in inches per hour, for a given frequency and for the duration equal to the time of concentration or other chosen frequency; and

$A$ is the drainage area, in acres.

The selected bridge sites and receiving waters were assessed based on the hydrologic and mixing characteristics at the bridge sites to select optimal sampling points before stormwater sampling. The hydrologic and water-quality characteristics at the selected bridge sites were assessed during two to three separate nonstorm events before storm sampling. Tagline supports were put in place on the stream banks at transects upstream and downstream from each bridge site to ensure consistency in monitoring. At each selected bridge site, two to three synoptic streamflow measurements were collected concurrently at potential transects upstream and downstream from the bridge during varying flow conditions to verify negligible change in streamflow between transects. Upstream and downstream sampling transects were closely positioned to minimize the contribution of nonbridge runoff but allow some influence from road-related factors other than bridge-deck runoff (for example, bridge abutment drainage features). Water-quality mixing within the study stream reach was evaluated by assessing changes in measurements of $\mathrm{pH}$, water temperature, specific conductance (SC), and dissolvedoxygen (DO) concentrations at 1-foot-depth profiles at 5 to 10 points along cross-sectional (lateral) transects upstream and downstream from the bridge.

Each bridge site had existing streamflow-gaging stations that ranged in their period of record (table 1). Tipping-bucket precipitation stations were installed alongside the streamflowgaging stations at the five selected bridge sites for the period of data collection. Rainfall gages were installed and serviced in accordance with USGS South Atlantic Water Science Center protocols and were installed to avoid splash from the highway. Data were recorded at 5-minute intervals. Rainfall gages provided the rainfall duration, intensity, and amount at the time of storm sampling as well as the time since the last rainfall (table 2). All streamflow-gaging stations and rainfall gages were checked and serviced as needed during the collection period. Rainfall and streamflow data were reviewed, approved, and stored in the USGS National Water Information System (NWIS) database (U.S. Geological Survey, 2016).

\section{Water-Quality Data Collection}

Water-quality samples were collected at the five selected bridge sites to obtain data to evaluate the effects of stormwater runoff from bridge decks on receiving waters (table 3 ). A total of five to six stream samples were collected during observable bridge runoff (from rainfall) at upstream and downstream transects concurrently at each bridge site. Routine sampling in the receiving water was conducted to collect 12 to 14 water samples at the upstream transect at gaged bridge sites during nonrunoff conditions. The total number of samples collected at the 5 bridge sites ranged from 17 to 20 . Measurements of $\mathrm{pH}$, water temperature, SC, and DO were made concurrently with EWI samples at each of the 10 increments across the transect cross section, and the median was computed for each sample.

At unwadeable bridge sites, sampling at the upstream and downstream transects at each bridge site used taglines attached to secured supports to ensure consistency in monitoring locations. Concurrent manual sampling at upstream and downstream transects used the EWI sampling technique that involved the collection of 10 width- and depth-integrated samples at evenly spaced points along the transect using a DH-81 isokinetic sampler (with a 3- or 6-foot handle, depending on depth; Edwards and Glysson, 1999; U.S. Geological Survey, 2006). The 10 samples were composited in a Teflon churn and processed and preserved according to USGS standard operating procedures (Wilde, 2004; U.S. Geological Survey, 2006). Timing of the collection of the EWI sample targeted the beginning of observable runoff from the bridge deck. In general, each EWI sample was collected as a single pass along the transect, capturing the first flush of the bridge deck during the first 15 to 20 minutes of the storm. The downstream sample collection was delayed by the downstream travel time (average stream velocity multiplied by travel distance) to sample the same "package" of water (Lagrangian sample). Although this sampling method captured a representative snapshot of the water conditions at the transects upstream and downstream from the bridge, this method did not allow for computing event-mean concentrations.

Rainfall amount and duration before and during the sample collection period were recorded from the rainfall gage. Water temperature, $\mathrm{pH}, \mathrm{DO}$, and $\mathrm{SC}$ were measured in the field at each sampling point (1-foot depth only) at the time of sampling using multiparameter sondes that were calibrated immediately before the onset of sampling and documented as part of the USGS quality-assurance program (Wilde, variously dated). Medians of the field measurements made at the 10 sampling points were used as the field measurements of record for the water-quality sample.

A broad range of constituent groups were measured in the stream-water receiving bridge-deck runoff (table 3; appendix tables 1.1-1.6). These constituents were observed in at least 20 percent of the 218 highway runoff studies summarized in Granato (2003) and included physical properties, suspended solids/sediment, nutrients, major ions, trace metals, and PAHs. Laboratory analyses of water samples were conducted at the USGS National Water Quality Laboratory (NWQL) in Denver, Colorado, except for suspended-sediment concentrations (SSCs), which were analyzed at the USGS Kentucky Sediment Laboratory in Louisville, Kentucky, and Escherichia coli (E. coli) and total coliform concentrations, which were analyzed at the SCDHEC-certified microbiology laboratory in the Columbia, South Carolina, office of the USGS South Atlantic Water Science Center. 
Table 2. Hydrologic and streamflow characteristics of the five selected bridge sites during storm sampling, South Carolina, 2014 to 2018.-Continued

[Dates shown as month/day/year. Time shown as hour:minute (military time). no., number; EST, eastern standard time; $\mathrm{ft}^{3} / \mathrm{s}$, cubic foot per second; in/hr, inch per hour; $\mathrm{ft}^{2}$, square foot; $\mathrm{ft}^{3}$, cubic foot; USGS, U.S. Geological Survey]

\begin{tabular}{|c|c|c|c|c|c|c|c|c|c|c|c|c|c|}
\hline \multirow[b]{2}{*}{$\begin{array}{c}\text { Storm } \\
\text { no. }\end{array}$} & \multirow[b]{2}{*}{$\begin{array}{l}\text { Sample } \\
\text { date }\end{array}$} & \multicolumn{2}{|c|}{ Sample time (EST) } & \multirow[b]{2}{*}{$\begin{array}{c}\text { Streamflow } \\
\text { at time of } \\
\text { sampling } \\
\left(\mathrm{ft}^{3} / \mathrm{s}\right)\end{array}$} & \multicolumn{5}{|c|}{ Rainfall during sampling event } & \multirow[b]{2}{*}{$\begin{array}{c}\text { Bridge-deck } \\
\text { area }\left(\mathrm{ft}^{2}\right)\end{array}$} & \multirow{2}{*}{$\begin{array}{l}\text { Estimated } \\
\text { volume of } \\
\text { potential } \\
\text { bridge-deck } \\
\text { runoff (ft3) }\end{array}$} & \multirow{2}{*}{$\begin{array}{c}\text { Mean } \\
\text { potential } \\
\text { bridge-deck } \\
\text { runoff rate } \\
\text { for the rain- } \\
\text { fall duration } \\
\left(\mathrm{ft}^{3} / \mathrm{s}\right)\end{array}$} & \multirow{2}{*}{$\begin{array}{c}\text { Ratio of } \\
\text { bridge-deck } \\
\text { runoff rate to } \\
\text { streamflow } \\
\text { (percent) }\end{array}$} \\
\hline & & Start & End & & $\begin{array}{c}\text { Amount } \\
\text { (inch) }\end{array}$ & $\begin{array}{l}\text { Duration } \\
\text { (minute) }\end{array}$ & $\begin{array}{l}\text { Duration } \\
\text { (hour) }\end{array}$ & $\begin{array}{l}\text { Intensity } \\
\text { (in/hr) }\end{array}$ & $\begin{array}{l}\text { Days } \\
\text { since } \\
\text { last } \\
\text { rainfall }\end{array}$ & & & & \\
\hline \multicolumn{14}{|c|}{ Bridge site at Lynches River at Effingham, South Carolina (USGS station 02132000)'1 } \\
\hline 1 & $02 / 21 / 2014$ & $11: 54$ & 12:09 & 2,000 & 0.25 & 14 & 0.23 & 1.07 & 6 & 26,070 & 543.1 & 0.647 & 0.03 \\
\hline 2 & $07 / 10 / 2014$ & $16: 39$ & $16: 56$ & 216 & 0.18 & 16 & 0.27 & 0.68 & 17 & 26,070 & 391.1 & 0.407 & 0.19 \\
\hline 3 & $11 / 17 / 2014$ & $14: 35$ & $14: 55$ & 281 & 0.02 & 10 & 0.17 & 0.12 & 1 & 26,070 & 43.5 & 0.072 & 0.03 \\
\hline 4 & $02 / 22 / 2015$ & $10: 39$ & $10: 56$ & 1,080 & 0.01 & 11 & 0.18 & 0.05 & 5 & 26,070 & 21.7 & 0.033 & 0.003 \\
\hline 5 & $03 / 05 / 2015$ & $15: 38$ & $15: 52$ & 2,660 & 0.10 & 7 & 0.12 & 0.86 & 4 & 26,070 & 217.3 & 0.517 & 0.02 \\
\hline \multicolumn{14}{|c|}{ Bridge site at North Fork Edisto River at Orangeburg, South Carolina (USGS station 02173500)'1 } \\
\hline 1 & $02 / 05 / 2014$ & $09: 34$ & 09:50 & 596 & 0.04 & 10 & 0.17 & 0.24 & 4 & 15,714 & 52.4 & 0.087 & 0.015 \\
\hline 2 & $03 / 06 / 2014$ & $12: 31$ & $12: 49$ & 727 & 0.09 & 24 & 0.4 & 0.23 & 8 & 15,714 & 117.9 & 0.082 & 0.011 \\
\hline 3 & 09/29/2014 & 09:09 & 09:31 & 386 & 0.06 & 31 & 0.52 & 0.12 & 7 & 15,714 & 78.6 & 0.042 & 0.011 \\
\hline 4 & $11 / 24 / 2014$ & 11:08 & $11: 27$ & 504 & 0.13 & 102 & 1.70 & 0.08 & 10 & 15,714 & 170.2 & 0.028 & 0.006 \\
\hline 5 & $01 / 23 / 2015$ & $12: 04$ & $12: 20$ & 553 & 0.02 & 10 & 0.17 & 0.12 & 8 & 15,714 & 26.2 & 0.044 & 0.008 \\
\hline 6 & $02 / 25 / 2015$ & $05: 26$ & $05: 42$ & 870 & 0.04 & 17 & 0.28 & 0.14 & 1 & 15,714 & 52.4 & 0.051 & 0.006 \\
\hline \multicolumn{14}{|c|}{ Bridge site at Turkey Creek above Huger, South Carolina (USGS station 02172035) ${ }^{1}$} \\
\hline 1 & $01 / 15 / 2016$ & $10: 14$ & $10: 32$ & 6.10 & 0.06 & 27 & 0.45 & 0.13 & 5 & 5,280 & 26.4 & 0.016 & 0.27 \\
\hline 2 & 06/06/2016 & 11:05 & $11: 25$ & 0 & 0.06 & 70 & 1.17 & 0.05 & 1 & 5,280 & 26.4 & 0.006 & 100 \\
\hline 3 & $01 / 26 / 2017$ & 09:42 & 09:58 & 57.0 & 0.02 & 61 & 1.02 & 0.02 & 4 & 5,280 & 8.8 & 0.002 & 0.004 \\
\hline 4 & $02 / 15 / 2017$ & $12: 31$ & $12: 48$ & 3.00 & 0.02 & 60 & 1.00 & 0.02 & 7 & 5,280 & 8.8 & 0.002 & 0.08 \\
\hline 5 & $03 / 13 / 2017$ & $15: 50$ & $15: 58$ & 0.52 & 0.02 & 88 & 1.47 & 0.01 & 1 & 5,280 & 8.8 & 0.002 & 0.32 \\
\hline \multicolumn{14}{|c|}{ Bridge site at South Fork Edisto River near Denmark, South Carolina (USGS station 02173000) ${ }^{1}$} \\
\hline 1 & $04 / 15 / 2015$ & $15: 21$ & $15: 39$ & 646 & 0.10 & 24 & 0.40 & 0.25 & 2 & 10,244 & 85.4 & 0.059 & 0.009 \\
\hline 2 & $09 / 24 / 2015$ & $11: 17$ & $11: 35$ & 288 & 0.03 & 45 & 0.75 & 0.04 & 12 & 10,244 & 25.6 & 0.009 & 0.003 \\
\hline 3 & $12 / 02 / 2015$ & $11: 30$ & $11: 45$ & 623 & 0.13 & 35 & 0.58 & 0.22 & 10 & 10,244 & 111 & 0.053 & 0.008 \\
\hline 4 & $02 / 03 / 2016$ & $16: 05$ & $16: 16$ & 825 & 0.06 & 21 & 0.35 & 0.17 & 6 & 10,244 & 51.2 & 0.041 & 0.005 \\
\hline 5 & $05 / 17 / 2016$ & $12: 19$ & $12: 40$ & 343 & 0.04 & 58 & 0.97 & 0.04 & 5 & 10,244 & 34.1 & 0.01 & 0.003 \\
\hline
\end{tabular}


Table 2. Hydrologic and streamflow characteristics of the five selected bridge sites during storm sampling, South Carolina, 2014 to 2018.—Continued

[Dates shown as month/day/year. Time shown as hour:minute (military time). no., number; EST, eastern standard time; $\mathrm{ft}^{3} / \mathrm{s}$, cubic foot per second; in/hr, inch per hour; $\mathrm{ft}^{2}$, square foot; $\mathrm{ft}^{3}$, cubic foot; USGS, U.S. Geological Survey]

\begin{tabular}{|c|c|c|c|c|c|c|c|c|c|c|c|c|c|}
\hline \multirow[b]{2}{*}{$\begin{array}{c}\text { Storm } \\
\text { no. }\end{array}$} & \multirow[b]{2}{*}{$\begin{array}{l}\text { Sample } \\
\text { date }\end{array}$} & \multicolumn{2}{|c|}{ Sample time (EST) } & \multirow[b]{2}{*}{$\begin{array}{c}\text { Streamflow } \\
\text { at time of } \\
\text { sampling } \\
\left(\mathrm{ft}^{3} / \mathrm{s}\right)\end{array}$} & \multicolumn{5}{|c|}{ Rainfall during sampling event } & \multirow[b]{2}{*}{$\begin{array}{l}\text { Bridge-deck } \\
\text { area }\left(\mathrm{ft}^{2}\right)\end{array}$} & \multirow[b]{2}{*}{$\begin{array}{l}\text { Estimated } \\
\text { volume of } \\
\text { potential } \\
\text { bridge-deck } \\
\text { runoff (ft3) }\end{array}$} & \multirow[b]{2}{*}{$\begin{array}{c}\text { Mean } \\
\text { potential } \\
\text { bridge-deck } \\
\text { runoff rate } \\
\text { for the rain- } \\
\text { fall duration } \\
\left(\mathrm{ft}^{3} / \mathrm{s}\right)\end{array}$} & \multirow[b]{2}{*}{$\begin{array}{c}\text { Ratio of } \\
\text { bridge-deck } \\
\text { runoff rate to } \\
\text { streamflow } \\
\text { (percent) }\end{array}$} \\
\hline & & Start & End & & $\begin{array}{c}\text { Amount } \\
\text { (inch) }\end{array}$ & $\begin{array}{l}\text { Duration } \\
\text { (minute) }\end{array}$ & $\begin{array}{l}\text { Duration } \\
\text { (hour) }\end{array}$ & $\begin{array}{l}\text { Intensity } \\
\text { (in/hr) }\end{array}$ & $\begin{array}{l}\text { Days } \\
\text { since } \\
\text { last } \\
\text { rainfall }\end{array}$ & & & & \\
\hline \multicolumn{14}{|c|}{ Bridge site at Fishing Creek at Highway 5 below York, South Carolina (USGS station 021473415) ${ }^{1}$} \\
\hline 1 & $11 / 29 / 2016$ & $10: 55$ & $11: 10$ & 0.26 & 0.04 & 20 & 0.33 & 0.12 & 16 & 4,032 & 13.4 & 0.011 & 4.3 \\
\hline 2 & 04/03/2017 & $13: 03$ & $13: 18$ & 5.8 & 0.06 & 18 & 0.30 & 0.20 & 3 & 4,032 & 20.2 & 0.019 & 0.32 \\
\hline 3 & 08/08/2017 & 09:50 & $10: 05$ & 0.78 & 0.10 & 255 & 4.25 & 0.43 & $<1$ & 4,032 & 33.6 & 0.002 & 0.28 \\
\hline 4 & $10 / 23 / 2017$ & $15: 45$ & $16: 20$ & 0.28 & 1.19 & 55 & 0.92 & 1.29 & 7 & 4,032 & 399.8 & 0.121 & 43.3 \\
\hline 5 & 02/07/2018 & 11:00 & $11: 26$ & 2.7 & 0.02 & 26 & 0.43 & 0.05 & 8 & 4,032 & 6.7 & 0.004 & 0.16 \\
\hline
\end{tabular}

${ }^{1}$ Station numbers and names are from the USGS National Water Information System database (USGS, 2016). See figure 1 for locations. 
[Sample and deployment dates shown as month/day/year. USGS, U.S. Geological Survey; ID, identifier; ft, foot; Routine, samples collected at the site during nonrunoff conditions; Storm_US, samples collected at the site during storm runoff conditions upstream from the bridge; Storm_DS, samples collected at the site during storm runoff conditions downstream from the bridge; PAH, polycyclic aromatic hydrocarbon]

\begin{tabular}{|c|c|c|c|c|c|c|c|c|c|c|c|c|c|c|}
\hline \multirow[b]{2}{*}{$\begin{array}{l}\text { USGS station } \\
\text { number' (fig. 1) }\end{array}$} & \multirow[b]{2}{*}{$\begin{array}{l}\text { USGS station } \\
\text { name }^{1}\end{array}$} & \multirow[b]{2}{*}{ Site ID } & \multirow{2}{*}{$\begin{array}{c}\text { Average } \\
\text { distance } \\
\text { from bridge } \\
\text { for sampling } \\
\text { (ft) }\end{array}$} & \multicolumn{4}{|c|}{ Water sampling } & \multicolumn{4}{|c|}{ Bacteria sampling } & \multicolumn{2}{|c|}{ Sample date } & \multirow{2}{*}{$\begin{array}{c}\text { Deployment } \\
\text { date (number } \\
\text { of artificial } \\
\text { substrates) }\end{array}$} \\
\hline & & & & $\begin{array}{l}\text { Sampling } \\
\text { period }\end{array}$ & Routine & $\begin{array}{l}\text { Storm } \\
\text { US }\end{array}$ & $\begin{array}{c}\text { Storm } \\
\text { DS }\end{array}$ & $\begin{array}{l}\text { Sampling } \\
\text { period }\end{array}$ & Routine & $\begin{array}{l}\text { Storm_ } \\
\text { US }\end{array}$ & $\begin{array}{l}\text { Storm } \\
\text { DS }\end{array}$ & $\begin{array}{c}\text { deck } \\
\text { sediment } \\
\text { (metals, } \\
\text { PAHs) }\end{array}$ & $\begin{array}{c}\text { Streambed } \\
\text { sediment } \\
\text { (metals, } \\
\text { PAHs) }\end{array}$ & \\
\hline 02132000 & $\begin{array}{l}\text { Lynches River } \\
\text { at Effingham, } \\
\text { South Carolina }\end{array}$ & Lynches & 50 & $\begin{array}{c}\text { January } 2014 \text { to } \\
\text { March } 2015\end{array}$ & 14 & 5 & 5 & $\begin{array}{l}\text { July } 2013 \\
\quad \text { to } \\
\text { March } \\
2015\end{array}$ & 3 & 5 & 5 & $11 / 14 / 2013$ & $08 / 27 / 2014$ & $\begin{array}{l}07 / 10 / 2014 \\
(6)\end{array}$ \\
\hline 02173500 & $\begin{array}{l}\text { North Fork } \\
\text { Edisto River } \\
\text { at Orangeburg, } \\
\text { South Carolina }\end{array}$ & NFEdisto & 50 & $\begin{array}{c}\text { January } 2014 \text { to } \\
\text { March } 2015\end{array}$ & 14 & 6 & 6 & $\begin{array}{l}\text { July } 2013 \\
\text { to } \\
\text { March } \\
2015\end{array}$ & 3 & 6 & 6 & $11 / 13 / 2013$ & 08/28/2014 & $\begin{array}{c}07 / 09 / 2014 \\
(6)\end{array}$ \\
\hline 02172035 & $\begin{array}{l}\text { Turkey Creek } \\
\text { above Huger, } \\
\text { South Carolina }\end{array}$ & Turkey & $20^{2}$ & $\begin{array}{l}\text { April } 2015 \text { to } \\
\text { March } 2017\end{array}$ & 14 & 5 & 5 & $\begin{array}{l}\text { March } \\
2015 \text { to } \\
\text { March } \\
2017\end{array}$ & 3 & 5 & 5 & $07 / 28 / 2015$ & 08/13/2015 & $\begin{array}{c}07 / 14 / 2015 \\
(14)\end{array}$ \\
\hline 02173000 & $\begin{array}{l}\text { South Fork } \\
\text { Edisto River } \\
\text { near Denmark, } \\
\text { South Carolina }\end{array}$ & SFEdisto & 50 & $\begin{array}{l}\text { April } 2015 \text { to } \\
\text { May } 2016\end{array}$ & 14 & 5 & 5 & $\begin{array}{l}\text { March } \\
2015 \\
\text { to May } \\
2016\end{array}$ & 3 & 5 & 5 & $07 / 28 / 2015$ & $08 / 12 / 2015$ & $\begin{array}{c}07 / 13 / 2015 \\
(14)\end{array}$ \\
\hline 021473415 & $\begin{array}{l}\text { Fishing Creek } \\
\text { at Highway } 5 \\
\text { below York, } \\
\text { South Carolina }\end{array}$ & Fishing & 35 & $\begin{array}{l}\text { July } 2016 \text { to } \\
\text { April } 2018\end{array}$ & 12 & 5 & 5 & $\begin{array}{c}\text { May } 2016 \\
\text { to April } \\
2018\end{array}$ & 3 & 5 & 5 & $06 / 22 / 2016$ & $12 / 01 / 2016$ & $\begin{array}{c}10 / 13 / 2016 \\
(14)\end{array}$ \\
\hline $\begin{array}{l}\text { Total environmental } \\
\text { samples }\end{array}$ & & & & NA & 68 & 26 & 26 & NA & 15 & 26 & 26 & 5 & 5 & $42^{3}$ \\
\hline Replicates & & & & & 6 & & & & 8 & & & 0 & 2 & 12 \\
\hline $\begin{array}{l}\text { Field or processing } \\
\text { (bacteria only) } \\
\text { blanks }\end{array}$ & & & & & 4 & & & & 67 & & & 0 & 0 & 0 \\
\hline
\end{tabular}

${ }^{1}$ Station numbers and names are from the USGS National Water Information System database (USGS, 2016).

${ }^{2}$ During extremely low to zero flow conditions, samples were collected from the bridge to prevent re-suspension of sediments upon entering the water for sampling.

${ }^{3}$ This total does not include samplers that were lost to sedimentation, which resulted in no sample collected. 
Water-column samples were analyzed for dissolved nitrate plus nitrite $\left(\mathrm{NO}_{3}+\mathrm{NO}_{2}\right)$ and ammonia, for total (dissolved plus particulate) organic nitrogen plus ammonia (total Kjeldahl nitrogen [TKN]), and for total phosphorus (TP) by the USGS NWQL in Denver, Colo. (Fishman, 1993; Patton and Truitt, 1992, 2000; Patton and Kryskalla, 2011; appendix table 1.1). Total nitrogen (TN) concentrations were computed as the sum of TKN and $\mathrm{NO}_{3}+\mathrm{NO}_{2}$ concentrations. If TKN or $\mathrm{NO}_{3}+\mathrm{NO}_{2}$ concentrations were reported as less than the laboratory reporting level (LRL), also described as censored, TN concentrations were computed by substituting zero for the censored value. Major ions (calcium, chloride, fluoride, magnesium, potassium, silica, sodium, and sulfate) in water samples were analyzed by inductively coupled plasma emission spectroscopy (Fishman and Friedman, 1989; Fishman, 1993; Clesceri and others, 1998; appendix table 1.2). Concentrations of dissolved cations were determined by inductively coupled plasma-atomic emission spectroscopy (Fishman, 1993), and concentrations of dissolved anions were determined by ion chromatography, as described by Fishman and Friedman (1989). Water samples for E. coli and total coliform concentrations were analyzed at the SCDHECcertified Columbia microbiology laboratory by enzyme substrate test methods (Colilert-18; Rice and others, 2012; Myers and others, 2014; South Carolina Department of Health and Environmental Control, 2017a).

Total recoverable analyses for trace metals were performed on whole-water samples; therefore, they reflect concentrations of trace metals adsorbed or lightly bound to suspended particles as well as trace metals in solution. Because total-recoverable analyses require total digestion of the sample, the results may include biologically available metals and metals from the underlying particulate mineralogy. Because acute and chronic aquatic-health criteria apply only to dissolved concentrations, dissolved trace-metal concentrations in water also were determined separately. Water samples were analyzed for most dissolved and total recoverable metals (after digestion; Hoffman and others, 1996) by inductively coupled plasma-optical emission spectrometry and whole-water collision/reaction cell inductively coupled plasma-mass spectrometry by the NWQL (Fishman and Friedman, 1989; Fishman, 1993; Garbarino and Struzeski, 1998; Garbarino and others, 2006; appendix table 1.3). Total and dissolved mercury were analyzed using cold vapor-atomic fluorescence spectrometry (Garbarino and Damrau, 2001; appendix table 1.3). Unfiltered water samples were analyzed for 17 PAHs by gas chromatography and mass spectrometry (Fishman, 1993; appendix table 1.4). Water samples also were analyzed for SSCs and suspended sediment finer than 62 microns by the USGS Kentucky Sediment Laboratory (Knott and others, 1993; Shreve and Downs, 2005).

\section{Sediment-Quality Surveys}

Many constituents associated with road runoff preferentially adsorb to particulates and, thus, are present in higher concentrations in sediment than in overlying water (Krein and Schorer, 2000; Singh and others, 2005). These hydrophobic constituents may include several trace metals and persistent organic compounds such as PAHs. Therefore, as a cumulative tracer of stormwater runoff from the bridge deck, streambed sediment was collected and analyzed for trace metals and PAHs to determine if concentrations differed between upstream and downstream transects at the five selected bridge sites because of accumulation from multiple bridge-deck runoff events.

Concentrations of material attached to sediment particles represent cumulative site-specific water-quality conditions on a time scale from weeks to years, depending on recent hydraulics at the site, whereas instantaneous fluvial water samples represent water quality on a time scale of minutes. Streambed sediments provide habitat for aquatic organisms and, thus, are an important component of stream ecosystems. Streambed-quality data also were used to interpret benthic macroinvertebrate communities at sites near bridges.

Sample collection and processing procedures followed protocols outlined in the USGS National Field Manual, chapter A8 (Radtke, 2005; U.S. Geological Survey, variously dated). Sediment samples were collected once at each of the five bridge sites (table 3). At each sampling location, 5 to 10 depositional zones likely to contain fine-grained sediment were identified. The surficial 1 to 2 centimeters of streambed sediment within each depositional zone was sampled. These zone samples were composited to produce a single sample from each location - one upstream and one downstream from the bridge. Pre-cleaned, Teflon scoops and glass compositing devices were used to collect and homogenize the subsamples. An aliquot of the homogenized sample was placed in an appropriate container and shipped to the USGS NWQL for analysis. At some bridge sites, the stream receives runoff from not only the bridge deck but also from the approach sections of the roadway and from ditches that are adjacent to the roadway. Sampling locations were selected to minimize the contribution of nonbridge runoff, but differences between upstream and downstream sediment chemistry could reflect some influence from road-related factors other than bridgedeck runoff. Additionally, two split replicates were collected to evaluate sampling bias (table 3; appendix table 2.2, available for download at https://doi.org/10.3133/sir20205046).

Streambed-sediment samples were analyzed for semivolatile organic compounds (SVOCs), including PAHs and phthalates, by gas chromatography/mass spectrometry by the NWQL (Zaugg and others, 2006; appendix table 1.6). Additionally, bed-sediment samples were analyzed by the NWQL for trace metals after total-digestion concentrations (Hoffman and others, 1996; U.S. Environmental Protection Agency, 1998) by inductively coupled plasma-optical emission spectrometry and whole-water collision/reaction cell 
inductively coupled plasma-mass spectrometry (Fishman and Friedman, 1989; Garbarino and Struzeski, 1998, Garbarino and others, 2006; appendix table 1.5). As mentioned previously, total-digestion concentrations may reflect the underlying mineralogy of the sediment. Sediment-quality guidelines are variously based on total-digestion or totalrecoverable concentrations.

Additionally, at each bridge, a one-time soil and debris sample on the bridge-deck surface was collected before storm and routine water samples were collected. Soil was collected from 5 to 10 locations on the bridge deck before storm sampling and analyzed for the same constituents by the same methods as above for the streambed sediment SVOCs (including PAHs), trace metals, and fecal indicator bacteria to evaluate potential contaminant sources. Bridge-deck samples for $E$. coli and total coliform concentrations were analyzed at the SCDHEC-certified USGS microbiology laboratory by enzyme substrate test methods (Colilert-18; Rice and others, 2012; Myers and others, 2014).

\section{Benthic Macroinvertebrate Community Surveys}

Benthic macroinvertebrate community surveys were conducted using Hester-Dendy multiplate artificial substrate samplers (fig. $2 A$ ) deployed at multiple upstream and downstream locations concurrently (table 3; fig. 2B). HesterDendy multiplate samplers were reported to be useful in systems where natural-substrate assessments pose a challenge (Casey and Kendall 1997). Artificial substrate sampling was recommended because of its ease of use and because of its ability to capture more species, its lower variability among samples, and its ability to provide uniformity in systems where natural substrates differ in character (Rosenberg and Resh, 1982; Barbour and others, 1999). Artificia1 substrate samplers represent the actual macroinvertebrate community of the stream if the artificial substrate simulates the natural substrate (Rosenberg and Resh, 1982). Because this was not always the case in this study, the main use of the samplers was to provide a consistent substrate comparison between upstream and downstream locations.

Samplers were placed in streams and anchored to a concrete construction block to prevent the multiple plates from touching the natural substrates. In water deeper than 4 feet (ft), a float (for example, a 1-quart cubitainer) was attached to the samplers to keep them within $4 \mathrm{ft}$ of the surface. The samplers were placed in runs, rather than pools or riffles, to ensure similar ecological settings and support sample intercomparisons. All samplers were deployed for a 6-week period and then retrieved. Samples were shipped to Pennington \& Associates, Inc. (Cookeville, Tennessee), where they were identified to the lowest practicable taxonomic level (Pennington, 2016). Taxonomic data (mainly the count of the number of individuals per species) were used to calculate different measures of water quality, including density, richness, diversity, and community metrics (for example, percentage of Ephemeroptera, Plecoptera, and Trichoptera spp. [EPT; mayflies, stoneflies, and caddisflies, respectively] taxa).

\section{Data Analysis}

Water-quality data were censored below the LRL for several constituents, including trace metals, nutrients, and PAHs. Therefore, a nonparametric statistical analysis on ranked data was used, in general, whereby censored values were given the same rank below estimated and quantitative (detections above the LRL) values (Childress and others, 1999; Helsel, 2005). Estimated values that were semiquantitative detections below the LRL were sometimes reported for PAHs and trace metals and in statistical analysis were given the same rank, above censored values but below detected values (Childress and others, 1999; Helsel, 2005). Exceptions to this approach were E. coli and total coliform concentrations that were above the maximum quantification level of the methods used. For most samples, a 1:100 dilution was used that translates to a LRL of 24,196 most probable number per 100 milliliters (MPN/100 mL), and the results would be censored as greater than 24,196 MPN/100 mL. For data analysis, the censored value of 24,196 MPN/100 mL was taken as the actual value, producing a negative bias to the data analysis, such that reported median and mean concentrations potentially are skewed lower than the reported concentrations.

Constituent concentrations in stream water represent conditions to which aquatic organisms were exposed. Prevailing water-quality standards also were expressed as concentrations. Therefore, comparing constituent concentrations (rather than loads or yields) at upstream and downstream transects at bridgedeck sites was the focus of this report.

Hydrologic and water-quality characterizations at each site were used to verify that no significant change in flow or water quality occurred between upstream and downstream transects during nonstorm conditions. Relative standard deviations (RSDs; standard deviation divided by the average), as a percentage, were computed for the hydrologic and waterquality data to evaluate the degree of variability (Mueller and others, 2015).

Results of the stream water-quality sampling, streambedsediment sampling, and benthic macroinvertebrate community structure at upstream and downstream transects were used to characterize the effects of bridge-deck runoff on conditions in receiving water. Water-quality data were summarized statistically using the R routine "sumStats" in the USGS R package "smwrStats" (Lorenz and DiCicco, 2017) and, for selected constituents, were represented graphically in simple boxplots or scatterplots (if number of samples were below five) using the R routine "boxPlot" in the USGS R package "smwrGraphs" (Lorenz and Diekoff, 2017). Before statistical and graphical analysis, water-quality data from all samplings were grouped as samples collected at (1) the upstream transect during nonstorm conditions (referred to herein as "routine samples"), (2) the upstream transect during storm conditions 
$\boldsymbol{A}$

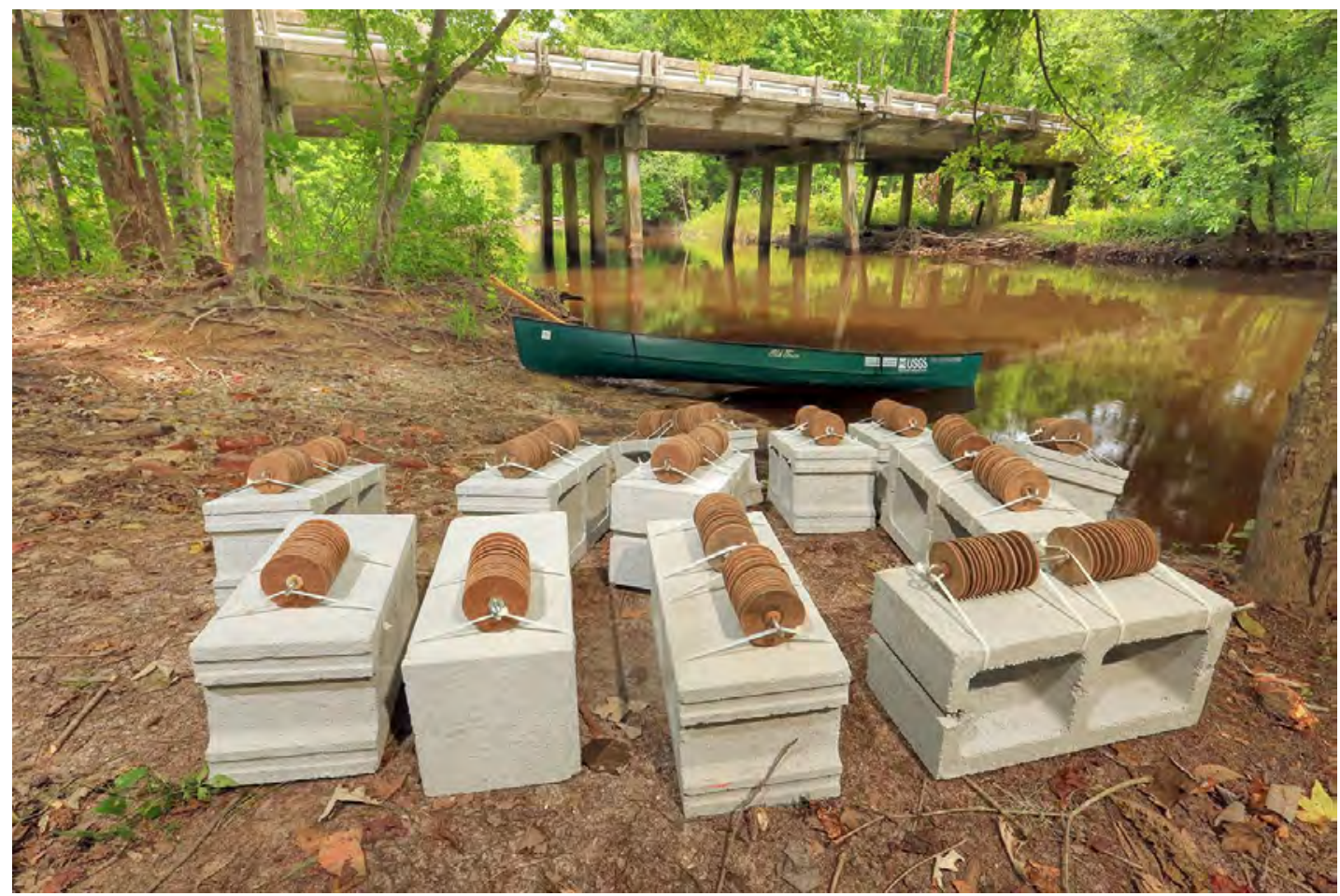

B

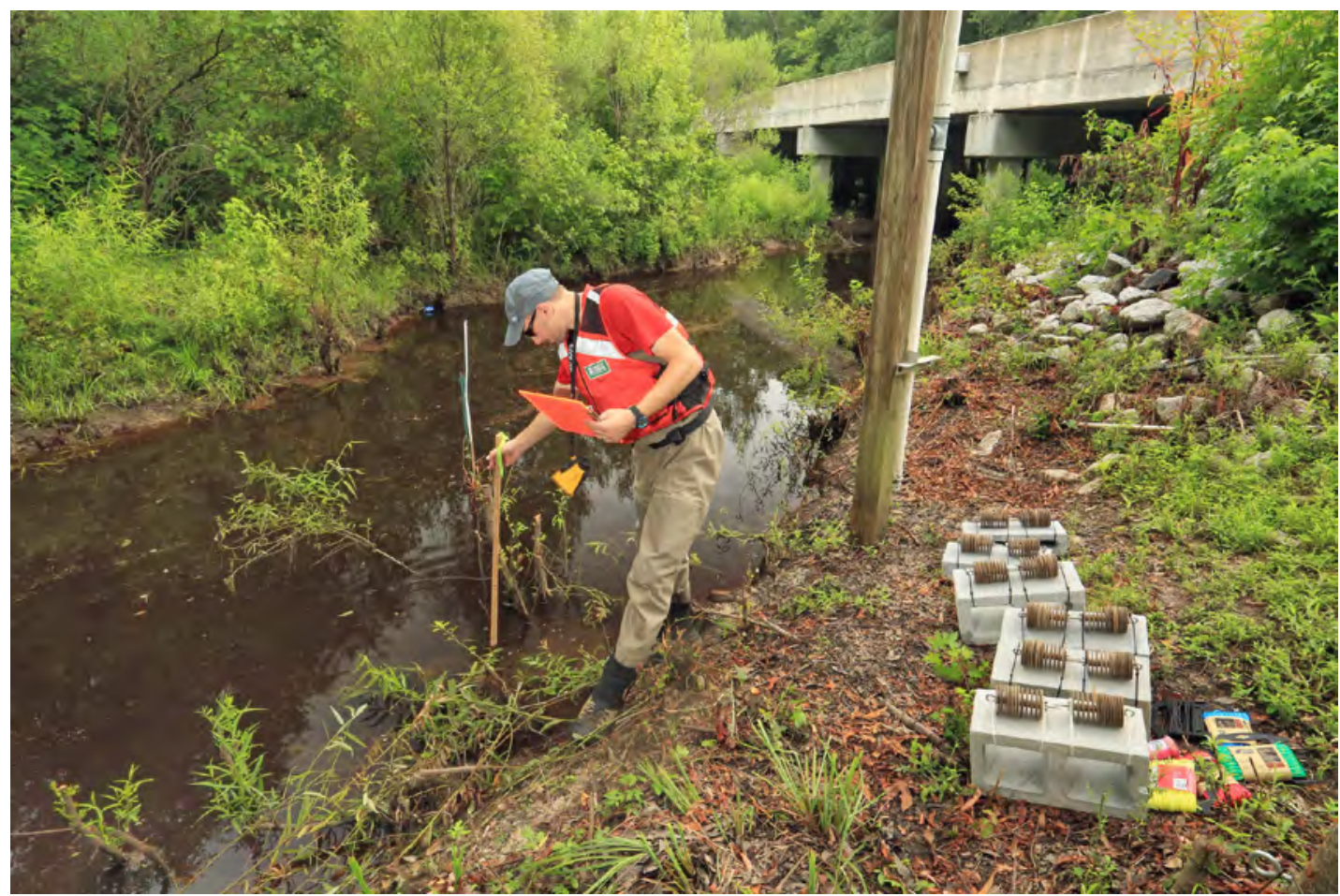

Figure 2. Photographs showing, $A$, Hester-Dendy artificial substrates prepared for deployment at the downstream transect on South Fork Edisto River near Denmark, South Carolina, and, B, a U.S. Geological Survey (USGS) hydrologist evaluating habitat before deployment at the downstream transect at Turkey Creek above Huger, South Carolina. Photographs by Alan Cressler, USGS. 
(referred to herein as "storm_US samples"), and (3) the downstream transect during storm conditions (referred to herein as "storm_DS samples"). Before plotting boxplots, water-quality data that were censored as less than the LRL were replaced with a value of one-half of the LRL (for plotting purposes only). Estimated values below the LRL were left as is. For boxplots with constituent concentrations near the LRL, a dashed line was drawn to represent the LRL for that constituent; therefore, symbols that fall below the LRL line represent either censored or estimated values. Differentiating the two types of data can be determined in the statistical tables associated with the plots.

Data were also compared to existing SCDHEC criteria (table 4). The SCDHEC has established freshwater aquatic-life criteria for 8 metals and human-health risk for 10 PAHs in stream water that were analyzed in this study (SCDHEC, 2014c). Metal criteria were compared to total recoverable metal concentrations in water and are hardness dependent. Metal criteria used in this report included the criterion maximum concentration (CMC) that represented the highest estimated metal concentration that aquatic biota can be exposed to without an unacceptable effect and the criterion continuous concentration (CCC) that represented the highest estimated metal concentration that aquatic biota can be exposed to continually without an unacceptable effect. Exposure of aquatic life to elevated metal concentrations during a storm would be applicable to CMC more than CCC. The SCDHEC also established human-health risk criteria for $12 \mathrm{PAH}$ compounds in water and organisms. Additionally, the SCDHEC established freshwater use criteria for DO, $\mathrm{pH}$, and turbidity in stream water. E. coli concentrations during sampling were compared to SCDHEC-established daily maximum concentration criterion for freshwater use of $349 \mathrm{MPN} / 100 \mathrm{~mL}$.

The main purpose of the study was to determine whether water-quality conditions changed between transects upstream and downstream from the bridge site when bridge-deck runoff was entering the stream during storms. To make this determination, statistical tests were used to determine if storm samples at the bridge locations varied from nonstorm samples. A permutation-based one-way analysis of variance was performed on individual constituent concentrations from all samplings grouped as routine, storm_US, and storm_DS samples (alpha $[\alpha]=0.05$ ). The permutation test used the one-way test routine in the coin package in R, "perm1way" (Hothorn and others, 2008, 2017). The permutation test computes an $F$ statistic, which is the signal to noise ratio of the data, to test the group means. The null hypothesis of the test is that there is no statistical difference of the group means. A probability value (or $p$-value) is computed during the analysis, and the null hypothesis is rejected at $p$-values below the $\alpha$ of 0.05 . Permutation test results are not affected by the distribution or symmetry of the nutrient data by using resampling when conducting hypothesis tests and are more robust than Kruskal Wallis nonparametric test on ranks. When the null hypothesis was rejected for the permutation test, a post-hoc nonparametric Wilcoxon pairwise comparison test with $p$-value adjustments for multiple testing (in this study we used Benjamini and Hochberg or false discovery rate [fdr] option, after Benjamini and Hochberg [1995]) was calculated between group levels to distinguish which groups were different than others ("pairwise.wilcox.test" routine from the R Core Team Stats package).

An additional, more robust approach was used to determine if constituent concentrations were greater in storm_DS samples than in storm_US samples during storms. A nonparametric Wilcoxon one-sided signed rank test was applied to the paired data from storm_DS and storm US samples for each storm (Helsel and Hirsch, 1992). The permutation-based "wilcoxsign_test" routine in the coin $R$ package was used to compute standardized $(Z)$ test statistic along with an approximate distribution from 10,000 replications to determine the $p$-value (Hothorn and others, 2008, 2017). Specifically, the test determined whether the storm_DS samples consistently had greater concentrations of a constituent in its stream water than the storm_US samples for all storms. The null hypothesis was that the constituent concentration in the stream water at the downstream and upstream transects were not different during storms, which was rejected if $p$-values were less than 0.05 .

Significant monotonic associations among constituent concentrations and streamflow, bridge, and rainfall characteristics were evaluated using nonparametric Spearman rho $(\rho)$ correlation analysis (Helsel and Hirsch, 1992). The data were summarized in table format using "corrplot" ("cor" routine; Wei, 2017) and "Hmisc" R packages (Harrell, 2018). The coefficient for this analysis is $\rho$. A $\rho$ ranges from 0 to 1 ; the closer the $\rho$ is to 1 , the stronger the correlation. A correlation resulting in a $p$-value less than the $\alpha$ level of 0.05 ( $p$-value less than $[<] 0.05$ ) is considered significant in this report. Caution is needed in interpreting correlation analysis results because a significant correlation proves only covariation, not cause and effect.

Trace metal and PAH concentrations in streambed sediment at upstream and downstream transects from the bridge were analyzed to determine if significantly higher levels of constituents within the bed sediment were measured downstream from the bridges. In the aquatic environment, small amounts of some metals, including copper, zinc, iron, manganese, and nickel are essential for biological systems to function, but excessive concentrations can be toxic. Conversely, other metals, including cadmium, mercury, arsenic, and lead, are not required for biological system function and, instead, have toxic effects on biological systems (Amiard and others, 1987). Aluminum-normalized metal enrichment ratios were computed to determine if metals seemed to be enriched downstream (Sinex and Helz, 1981; Abrahim and Parker, 2008). Enrichment factors or ratios (ERs) were computed as the aluminum-normalized metal concentration at the transect downstream from the bridge divided by the aluminum-normalized metal concentration at the transect upstream from the bridge (Sinex and Helz, 
1981). According to the past studies, sediment ERs of $0.5 \leq \mathrm{ER} \leq 1.5$ indicate that metals may be completely derived from natural or lithogenic processes. ERs of greater than $(>)$ 1.5 indicate enrichment whereby a significant fraction of the trace metal in sediment is derived from non-natural processes or anthropogenic sources (Zhang and others, 2009). In this study, ERs are used to indicate enrichment relative to baseline conditions at the upstream transect that is not related to natural or lithogenic processes (not necessarily representative of enrichment relative to true background or pristine conditions).

PAHs in streambed sediment and bridge-deck particulates likely originate from many sources including asphalt, motor oil, tire particles, combustion particles, and natural materials (MacDonald and others, 2000; Ingersoll and others, 2000). Ratios of certain PAH compounds have been used in previous studies to provide information on original sources of these compounds (table 5; Yunker and others, 2002). Several PAH ratios were computed and used to evaluate potential sources of bridge-deck sediment for PAHs in streambed sediments in this study.

The presence of many species that compose the benthic macroinvertebrate community requires the use of robust statistical methods to identify changes between locations. For this dataset, several routines in the PRIMER 7.0 multivariate statistical software program were used to evaluate changes between upstream and downstream benthic macroinvertebrate communities (Clarke, 1993; Clarke and others, 2014; Clarke and Gorley, 2015). A nonhierarchical cluster analysis (LINKTREE), with similarity profile analysis (SIMPROF with 999 permutations) tests, was performed to identify if statistically significant groupings of sites with similar benthic macroinvertebrate community patterns were present. Hypotheses of spatial (upstream versus downstream transects; habitat characteristics) differences or similarities in the taxonomic composition were quantified with a series of one-way analysis of similarity (ANOSIM) tests, a multivariate, nonparametric analog of analysis of variance (Clarke and others, 2014). The ANOSIM test results are given as a global $R$, which is a measure (between 0 and 1) of the degree of separation of the groups in two-dimensional space. Because Global $R$ is a correlation-based coefficient, its value does not change with added samples; only the level of significance ( $p$-value) is subject to change. The ANOSIM tests performed for this study used 100 permutations, producing a minimum $p$-value of 0.001 (Clarke and others, 2014).

\section{Quality Assurance and Quality Control}

The velocity and pressure measurement accuracy of the acoustic Doppler velocity meters and pressure sensors used in this study were tested by the USGS Hydrologic Instrumentation Facility before installation and again at the end of the study. Periodically, discrete volumetric flow measurements were made by study personnel to check performance of the velocity meters. Installation, operation, and maintenance of rainfall gages at the 5 bridge-deck sites followed manufacturers' specifications and USGS guidelines (Turnipseed and Sauer, 2010). The USGS operated and maintained continuous-record streamflow-gaging stations at all sites as part of this study. Rainfall, stage, and streamflow data were collected, processed, and analyzed in accordance with Turnipseed and Sauer (2010) and Rantz and others (1982). Final results were entered into the NWIS database. Current (real-time) and historical data for project streamflowand rainfall-gaging stations are publicly available at the USGS NWIS database (U.S. Geological Survey, 2016).

Equipment cleaning, sample collection, and sample processing followed procedures outlined in U.S. Geological Survey (variously dated). These protocols were developed to prevent contamination of samples containing low-level concentrations of trace metals and have been used by the USGS since 1994. Routine and storm samples collected by USGS were analyzed at the USGS NWQL in Denver, Colo., which is accredited by the National Environmental Laboratory Accreditation Conference. The NWQL adheres to a comprehensive quality management system to ensure the quality of its work processes, products, and services (Maloney, 2005). Additional laboratories included a contract laboratory for the benthic macroinvertebrate taxonomic analyses, the USGS Kentucky Sediment Laboratory, and the USGS South Carolina microbiology laboratory, which maintained certification with SCDHEC during the study. Each laboratory conducted internal checks for bias and variability using laboratory blanks, surrogates, and spikes. Results of these analyses were provided for review to ensure that study data-quality objectives were met.

Study personnel and a water-quality specialist reviewed all field and laboratory analytical results. Requests for re-analysis were made to the NWQL and other participating laboratories when results were in question. Data were entered into the USGS NWIS database. Data stored in NWIS received automated quality-control checks for data consistency and are available for public access (U.S. Geological Survey, 2016). Environmental data used in analyses in this report are provided in Romanok and others (2020).

Results from environmental sampling may be subject to bias (or systematic error) and variability (or random error) during sample collection, processing, and analysis. The nature and magnitude of bias and variability were determined by analysis of quality-control samples associated with the 105 environmental (medium code of WS) water and 10 streambed-sediment (medium code of SB) samples used in the data analysis. Quality-control samples for stream-water sampling included 4 inorganic field blanks (nutrients, major ions, and metals), 3 organic field blanks (SVOCs), and 6 field replicates (table 3; appendix table 2.1, available for download at https://doi.org/10.3133/sir20205046). Quality-control samples associated with the 10 streambed-sediment samples included 1 concurrent and 1 split-sample field replicate for all constituents, and matrix spikes for SVOCs (table 3; appendix table 2.2). 
Table 4. South Carolina Department of Health and Environmental Control established human health and freshwater aquatic-life criteria for metals (total recoverable concentrations) in freshwater and aquatic-health threshold effect and probable effect concentrations for polycyclic aromatic hydrocarbons.

[CAS, Chemical Abstracts Service; SCDHEC, South Carolina Department of Health and Environmental Control; CMC, criterion maximum concentration for a hardness of 25 milligrams per liter $(\mathrm{mg} / \mathrm{L})$ as calcium carbonate; $\mu \mathrm{g} / \mathrm{L}$, microgram per liter; $\mathrm{CCC}$, criterion continuous concentration for a hardness of $25 \mathrm{mg} / \mathrm{L}$ as calcium carbonate; MCL, maximum contaminant level; TEC, threshold effect concentration; $\mathrm{mg} / \mathrm{kg}$, milligram per kilogram; PEC, probable effect concentration; - , not determined; PAH, polycyclic aromatic hydrocarbon; NA, not applicable; NTU, nephelometric turbidity unit; MPN/100 mL, most probable number per 100 milliliters]

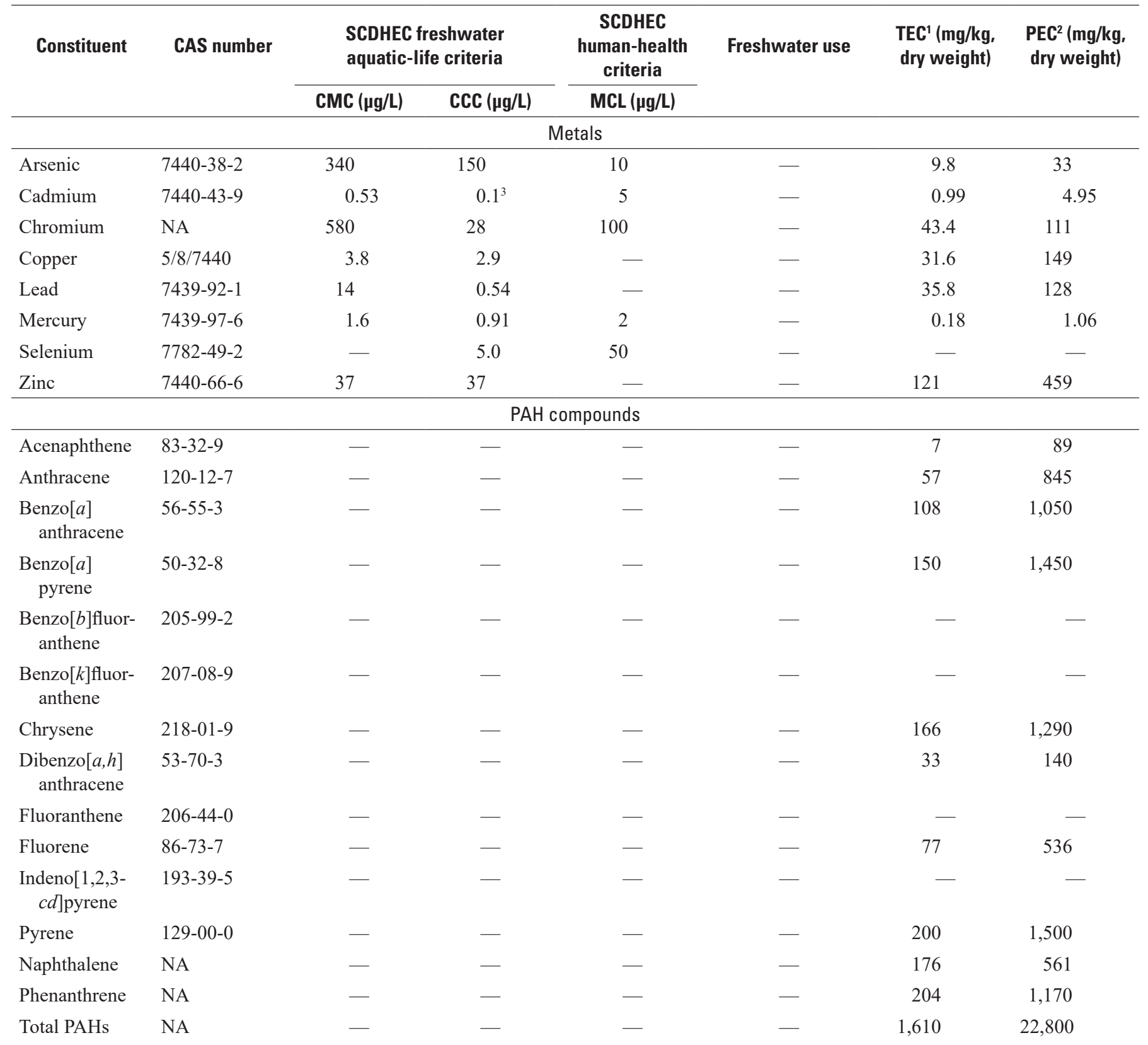


Table 4. South Carolina Department of Health and Environmental Control established human health and freshwater aquatic-life criteria for metals (total recoverable concentrations) in freshwater and aquatic-health threshold effect and probable effect concentrations for polycyclic aromatic hydrocarbons.-Continued

[CAS, Chemical Abstracts Service; SCDHEC, South Carolina Department of Health and Environmental Control; CMC, criterion maximum concentration for a hardness of 25 milligrams per liter $(\mathrm{mg} / \mathrm{L}$ ) as calcium carbonate; $\mu \mathrm{g} / \mathrm{L}$, microgram per liter; $\mathrm{CCC}$, criterion continuous concentration for a hardness of $25 \mathrm{mg} / \mathrm{L}$ as calcium carbonate; MCL, maximum contaminant level; TEC, threshold effect concentration; $\mathrm{mg} / \mathrm{kg}$, milligram per kilogram; PEC, probable effect concentration; - , not determined; PAH, polycyclic aromatic hydrocarbon; NA, not applicable; NTU, nephelometric turbidity unit; MPN/100 mL, most probable number per 100 milliliters]

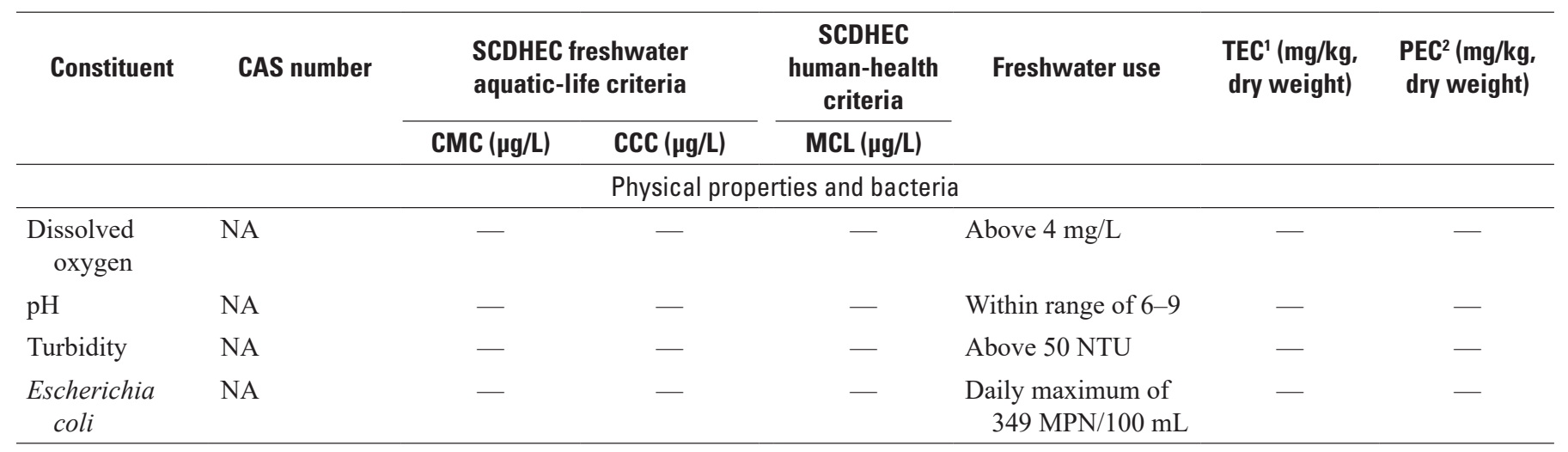

${ }^{1}$ MacDonald and others (2000).

${ }^{2}$ Ingersoll and other (2000).

${ }^{3}$ Criteria was lower than the reporting limits for the laboratory analysis (so unable to compare results to criteria).

Table 5. Selected polycyclic aromatic hydrocarbon ratios and potential sources of those ratios.

[Modified from Yunker and others (2002)]

\begin{tabular}{lccc}
\hline $\begin{array}{c}\text { Polycyclic aromatic hydrocarbon } \\
\text { ratio }\end{array}$ & Petroleum & Potential source of ratio & \\
\cline { 2 - 4 } & $<0.1$ & $>0.1$ & $>0.1$ \\
\hline $\begin{array}{c}\text { Anthracene/ } \\
\text { (Anthracene+Phenanthrene) }\end{array}$ & $<0.4$ & 0.4 to 0.5 & $>0.5$ \\
$\begin{array}{l}\text { Fluoranthene/ } \\
\text { (Fluoranthen+Pyrene) }\end{array}$ & $<0.2$ & 0.2 to 0.5 (mix) & $>0.5$ \\
$\begin{array}{l}\text { Indeno[1,2,3-cd]pyrene/ } \\
\text { (Indeno[1,2,3-cd] } \\
\text { pyrene+Benzo[ghi]perylene) }\end{array}$ & & & \\
\hline
\end{tabular}


Three to eight field replicates, depending on constituent, were collected during water samplings (routine and storm) to assess bias in sampling, processing, and laboratory methods (table 3; appendix tables 2.1,2.2). RSDs of the environmental and replicate sample pair were computed for each constituent, and then medians of the RSDs were computed (table 6). Bias was considered to be present for a constituent when its median RSD was greater than 20 percent. For water samples, only dissolved copper concentrations indicated probable bias. The 6 replicate-environmental paired samples for copper had RSDs that ranged from 0 to 49.0 percent (appendix table 2.1); this bias was considered when evaluating differences in dissolved copper concentrations for this study.

Two field replicates were collected during the one-time sediment survey to assess bias in sampling, processing, and laboratory methods (table 3; appendix table 2.2). Median RSDs of the environmental and replicate pairs for the SVOCs, including PAHs, ranged from 0 to 11.8 percent. But RSD was unable to be determined for 10 SVOCs in the August 12, 2015, replicate sample because one of the environmental-replicate pairs had a detection below the LRL, while the other did not (appendix table 2.2). Metal analysis extracted from sediment had poor reproducibility. The August 27, 2014, replicate sample at Lynches had the poorest reproducibility of the two replicate samplings, especially for five of the metals (lead, arsenic, zinc, cobalt, and manganese RSDs of 31.9, 47.1, 64.8, 78.6, and 121.8 percent, respectively). However, some improvement in reproducibility was observed in the August 12, 2015, replicate sampling that had RSDs that ranged from 0 to 47.1 percent. This performance bias in reproducibility was accounted for when evaluating differences in metal concentrations in sediment for this study (appendix table 2.2).

No detectable concentrations of analyzed constituents were observed in the organic or inorganic field blanks, except for one detection of dissolved ammonia at a level of 0.014 milligram per liter $(\mathrm{mg} / \mathrm{L})$, which is near the LRL of $0.010 \mathrm{mg} / \mathrm{L}$. The ammonia data were re-censored before data analysis to reflect a higher LRL of $0.014 \mathrm{mg} / \mathrm{L}$, based on the 90th percentile with 90-percent confidence of all field blank concentrations for this constituent (appendix table 2.3, available for download at https://doi.org/10.3133/sir20205046; Mueller and others, 2015). 
Table 6. Relative standard deviations of environmental and replicate samples from stream water and streambed sediments near the five selected bridge sites, South Carolina, 2014 to 2017.

[NWIS, National Water Information System; RSD, relative standard deviation; ND, detected in one sample at a level below the laboratory reporting level but not in the other sample; yellow highlighted cells represent RSDs that are between 20 and 25 percent; red highlighted cells represent RSDs greater than 25 percent]

\begin{tabular}{|c|c|c|c|}
\hline Constituent & NWIS parameter code & Number of replicates & Median RSD' (percent) \\
\hline \multicolumn{4}{|c|}{ Stream-water samples } \\
\hline \multicolumn{4}{|c|}{ Suspended sediment } \\
\hline Suspended-sediment concentration & 80154 & 4 & 5.4 \\
\hline \multicolumn{4}{|c|}{ Fecal indicator bacteria } \\
\hline Total coliforms, defined substrate test method, water & 50569 & 8 & 4.1 \\
\hline \multicolumn{4}{|c|}{ Major ions } \\
\hline Calcium, water, filtered & 915 & 6 & 2.5 \\
\hline Magnesium, water, filtered & 925 & 6 & 2.0 \\
\hline Potassium, water, filtered & 935 & 6 & 2.6 \\
\hline Chloride, water, filtered & 940 & 6 & 0.1 \\
\hline Fluoride, water, filtered & 950 & 6 & 2.2 \\
\hline Silica, water, filtered & 955 & 6 & 0.5 \\
\hline Sulfate, water, filtered & 945 & 6 & 0.1 \\
\hline \multicolumn{4}{|c|}{ Nutrients } \\
\hline Ammonia plus organic nitrogen, water, unfiltered & 625 & 6 & 5.4 \\
\hline Ammonia $\left(\mathrm{NH}_{3}+\mathrm{NH}_{4}^{+}\right)$, water, filtered & 608 & 6 & 2.9 \\
\hline Nitrate plus nitrite, water, filtered & 631 & 5 & 0.6 \\
\hline Organic nitrogen, water, unfiltered & 605 & 6 & 5.7 \\
\hline Chromium, water, filtered & 1030 & 6 & 0.7 \\
\hline Chromium, water, unfiltered, recoverable & 1034 & 6 & 4.4 \\
\hline Copper, water, filtered & 1040 & 6 & 26.2 \\
\hline Copper, water, unfiltered, recoverable & 1042 & 6 & 1.9 \\
\hline Lead, water, filtered & 1049 & 6 & 6.0 \\
\hline Lead, water, unfiltered, recoverable & 1051 & 6 & 1.7 \\
\hline Mercury, water, filtered & 71890 & 6 & 0 \\
\hline Mercury, water, unfiltered, recoverable & 71900 & 6 & 3.3 \\
\hline Zinc, water, filtered & 1090 & 6 & 0 \\
\hline Zinc, water, unfiltered, recoverable & 1092 & 6 & 1.3 \\
\hline
\end{tabular}


Table 6. Relative standard deviations of environmental and replicate samples from stream water and streambed sediments near the five selected bridge sites, South Carolina, 2014 to 2017.-Continued

[NWIS, National Water Information System; RSD, relative standard deviation; ND, detected in one sample at a level below the laboratory reporting level but not in the other sample; yellow highlighted cells represent RSDs that are between 20 and 25 percent; red highlighted cells represent RSDs greater than 25 percent]

\begin{tabular}{|c|c|c|c|}
\hline Constituent & NWIS parameter code & Number of replicates & Median RSD' (percent) \\
\hline \multicolumn{4}{|c|}{ Trace elements } \\
\hline Arsenic, water, filtered & 1000 & 6 & 2.0 \\
\hline Selenium, water, filtered & 1145 & 6 & 4.4 \\
\hline Selenium, water, unfiltered & 1147 & 6 & 8.0 \\
\hline 9H-Fluorene, water, unfiltered, recoverable & 34381 & 6 & 0 \\
\hline Acenaphthene, water, unfiltered, recoverable & 34205 & 6 & 0 \\
\hline Acenaphthylene, water, unfiltered, recoverable & 34200 & 6 & 0 \\
\hline Anthracene, water, unfiltered, recoverable & 34220 & 6 & 0 \\
\hline Benzo $[a]$ anthracene, water, unfiltered, recoverable & 34526 & 6 & 0 \\
\hline Benzo $[k]$ fluoranthene, water, unfiltered, recoverable & 34242 & 6 & 0 \\
\hline Chrysene, water, unfiltered, recoverable & 34320 & 6 & 0 \\
\hline Dibenzo $[a, h]$ anthracene, water, unfiltered, recoverable & 34556 & 6 & 0 \\
\hline Fluoranthene, water, unfiltered, recoverable & 34376 & 6 & 0 \\
\hline Indeno[1,2,3-cd]pyrene, water, unfiltered, recoverable & 34403 & 6 & 0 \\
\hline Naphthalene, water, unfiltered, recoverable & 34696 & 6 & 0 \\
\hline Nitrobenzene, water, unfiltered, recoverable & 34447 & 6 & 0 \\
\hline Phenanthrene, water, unfiltered, recoverable & 34461 & 6 & 0 \\
\hline Cobalt, bed sediment, recoverable, dry weight & 1038 & 2 & 49.7 \\
\hline Copper, bed sediment, recoverable, dry weight & 1043 & 2 & 6.4 \\
\hline Iron, bed sediment, total digestion, dry weight & 1170 & 2 & 23.5 \\
\hline Lead, bed sediment, recoverable, dry weight & 1052 & 2 & 29.4 \\
\hline Manganese, bed sediment, recoverable, dry weight & 1053 & 2 & 73.1 \\
\hline Molybdenum, bed sediment, recoverable, dry weight & 1063 & 2 & 0 \\
\hline Nickel, bed sediment, recoverable, dry weight & 1068 & 2 & 19.3 \\
\hline Vanadium, bed sediment, recoverable, dry weight & 64849 & 2 & 20.8 \\
\hline Zinc, bed sediment, recoverable, dry weight & 1093 & 2 & 40.8 \\
\hline \multicolumn{4}{|c|}{ Trace elements } \\
\hline Arsenic, bed sediment, recoverable, dry weight & 64847 & 2 & 35.4 \\
\hline Boron, bed sediment, recoverable, dry weight & 1023 & 2 & 0 \\
\hline Selenium, bed sediment, recoverable, dry weight & 64848 & 2 & 23.6 \\
\hline
\end{tabular}


Table 6. Relative standard deviations of environmental and replicate samples from stream water and streambed sediments near the five selected bridge sites, South Carolina, 2014 to 2017.-Continued

[NWIS, National Water Information System; RSD, relative standard deviation; ND, detected in one sample at a level below the laboratory reporting level but not in the other sample; yellow highlighted cells represent RSDs that are between 20 and 25 percent; red highlighted cells represent RSDs greater than 25 percent]

\begin{tabular}{|c|c|c|c|}
\hline Constituent & NWIS parameter code & Number of replicates & Median RSD ${ }^{1}$ (percent) \\
\hline \multicolumn{4}{|c|}{ Semivolatile organic compounds (includes polycyclic aromatic hydrocarbons) } \\
\hline Carbazole, solids, recoverable, dry weight & 63194 & 2 & 0 \\
\hline Pentachloroanisole, solids, recoverable, dry weight & 64119 & 2 & 0 \\
\hline Pentachloronitrobenzene, solids, recoverable, dry weight & 63650 & 2 & 0 \\
\hline 1,6-Dimethylnaphthalene, solids, recoverable, dry weight & 64099 & 2 & 0 \\
\hline 1-Methyl-9H-fluorene, solids, recoverable, dry weight & 64100 & 2 & 0 \\
\hline 1-Methylphenanthrene, solids, recoverable, dry weight & 64101 & 2 & 0 \\
\hline 1-Methylpyrene, solids, recoverable, dry weight & 64102 & 2 & 0 \\
\hline 2,3,6-Trimethylnaphthalene, solids, recoverable, dry weight & 64103 & 2 & 0 \\
\hline $4 H$-Cyclopenta $[\mathrm{def}]$ phenanthrene, solids, recoverable, dry weight & 64106 & 2 & 0 \\
\hline 9,10-Anthraquinone, solids, recoverable, dry weight & 63181 & 2 & 0 \\
\hline 9H-Fluorene, solids, recoverable, dry weight & 64107 & 2 & 0 \\
\hline Acenaphthene, solids, recoverable, dry weight & 64108 & 2 & 0 \\
\hline Acenaphthylene, solids, recoverable, dry weight & 64109 & 2 & 0 \\
\hline Anthracene, solids, recoverable, dry weight & 63180 & 2 & ND \\
\hline Benzo $[a]$ anthracene, solids, recoverable, dry weight & 63610 & 2 & ND \\
\hline Benzo $[a]$ pyrene, solids, recoverable, dry weight & 63183 & 2 & ND \\
\hline $\operatorname{Dibenzo}[a, h]$ anthracene, solids, recoverable, dry weight & 64116 & 2 & 0 \\
\hline Dibenzothiophene, solids, recoverable, dry weight & 64117 & 2 & 0 \\
\hline Diethyl phthalate, solids, recoverable, dry weight & 63202 & 2 & 0 \\
\hline Fluoranthene, solids, recoverable, dry weight & 63208 & 2 & ND \\
\hline Indeno $[1,2,3-c d]$ pyrene, solids, recoverable, dry weight & 64118 & 2 & ND \\
\hline Naphthalene, solids, recoverable, dry weight & 63220 & 2 & 0 \\
\hline Perylene, solids, recoverable, dry weight & 64120 & 2 & 11.8 \\
\hline Phenanthrene, solids, recoverable, dry weight & 63224 & 2 & 0 \\
\hline Phenanthridine, solids, recoverable, dry weight & 64121 & 2 & 0 \\
\hline Pyrene, solids, recoverable, dry weight & 63227 & 2 & ND \\
\hline
\end{tabular}

${ }^{1}$ RSD was computed as the standard deviation of the environmental and replicate pair divided by the average of the environmental and replicate pair multiplied by 100 . 


\section{Description of the Study Areas at Selected Bridge Sites}

The following subsections provide detailed descriptions of each bridge site. The selected bridges had a range of AADT counts (from 2,600 to 24,300 vehicles per day), bridge-surface materials (concrete and asphalt), and bridge-deck areas (from 4,032 to 26,070 square feet) (tables 1,2). Additionally, the surface water that received the storm runoff from the bridge deck varied in streamflow quantity; daily mean streamflow ranged from 0 to 24,500 cubic feet per second $\left(\mathrm{ft}^{3} / \mathrm{s}\right)$, and averaged from 12.3 to $718 \mathrm{ft}^{3} / \mathrm{s}$ (table 1) at the five bridge sites

\section{Lynches River}

Lynches River (fig. 3) is a blackwater system that is characterized by slow-moving dark water with naturally low $\mathrm{pH}$ and DO conditions. Blackwater rivers are common in the Lower Coastal Plain physiographic province of South Carolina, and their dark waters result from tannic acids leached from decaying organic debris, especially tree leaves. The tannic acids are easily transported in the sandy soils from wetland areas to the river (Bradley and others, 2010). The characteristics of blackwater systems also are conducive to bioaccumulation of mercury in fish (Journey and others, 2013; Riva-Murray and others, 2013).

The South Carolina Department of Natural Resources has listed Lynches River, located in a relatively rural part of the State, as one of 10 scenic rivers in South Carolina; however, the 3.9-mile stretch upstream (west) of U.S. Highway 52 (US 52) was excluded from the designation because it is more developed than the remaining area under consideration.

The Lynches River at Effingham, S.C., streamflowgaging station (02132000) is off US 52 south of Effingham in Florence County, S.C., and the river drains an area of 1,030 square miles ( $\mathrm{mi}^{2}$; table 1 ; figs. 1,3$)$. This station has a period of record from 1930 to present (2018). Daily mean streamflow at this location had a mean of $649 \mathrm{ft}^{3} / \mathrm{s}$ and ranged from 69.2 to $24,500 \mathrm{ft}^{3} / \mathrm{s}$ during the period of record.

At the streamflow-gaging station location, US 52 runs from north to south and has a four-lane twin-span bridge over Lynches River, which flows from west to east. The station is on the downstream side of the bridge on the north bank. The combined bridge spans are about $660 \mathrm{ft}$ long and about $39.5 \mathrm{ft}$ wide, covering an area of about 26,070 square feet (tables 1 , 2). AADT counts at SCDOT Florence County station 117, which is on US 52 just north of the bridge, were 14,500, 16,500 , and 18,400 in 2013,2014 , and 2015 , respectively (fig. 3; SCDOT, 2018). Stormwater drainage from the bridge deck differs slightly between the north- and south-bound spans. The south-bound span has a bridge deck with evenly spaced side openings that drain over both edges of the deck. The north-bound span has a bridge deck with evenly spaced downspouts on both edges of the deck that drain directly from the deck to the water below. Additionally, a boat ramp is just upstream from the bridge on the southern bank of the Lynches River, and a parking area is under the bridge. A few hundred yards downstream from the US 52 bridge on Lynches River is a train trestle bridge.

The SCDHEC monitors the water-quality conditions in the Lynches River at the SCDHEC station PD-041, co-located at the USGS gaging station 02132000 (South Carolina Department of Health and Environmental Control, 2014a, b, c, 2015, 2017b). In 2014, the SCDHEC reported pH excursions in this freshwater classified river; these were considered typical of blackwater systems and characterized as natural. However, there is concern about significant decreasing trends in DO and increasing trends in 5-day biochemical oxygen demand and fecal coliform bacteria concentrations at the SCDHEC station PD-041. Periodic fecal coliform excursions were only partially supportive of recreational use in this part of the Lynches River. One active National Pollutant Discharge Elimination System minor industrial facility is upstream from the bridge (McCall Farms, Inc.; SC0039284) near Carter Creek, a tributary to Lynches River (South Carolina Department of Health and Environmental Control, 2015). A fish consumption advisory because of elevated mercury in fish tissue has also been issued for this part of the Lynches River (South Carolina Department of Health and Environmental Control, 2015, 2017b).

The Lynches River at the US 52 bridge (referred to herein as the "Lynches bridge site") was selected as one of the bridge sites for USGS stormwater sampling. At this site, water-quality samples (routine and storm) were collected at transects about $50 \mathrm{ft}$ upstream and $50 \mathrm{ft}$ downstream from the bridge spans. Tagline supports were installed at the transects on both banks to ensure the same distance from the bridge was monitored for all samplings. Deployment of the six HesterDendy multiplate artificial substrate samplers, which were used for benthic macroinvertebrate community surveys, deviated slightly (about $20 \mathrm{ft}$ ) upstream and downstream from the transect locations to meet habitat (for example, stream depth, velocity, and bed substrate) requirements. Streambed-sediment sampling also deviated slightly from the transects by collecting samples at multiple points within a 10 -ft zone around the upstream and downstream transects to target depositional zones, where possible. Polecat Branch, a small tributary to Lynches River, flows west to northeast until it reaches US 52; then, it flows north along the west (south bound) side of US 52 until its confluence with the Lynches River just a few feet upstream from the upstream transect (fig. 3). Therefore, both transects at the Lynches bridge site captured the contribution from the Polecat Branch discharge. 


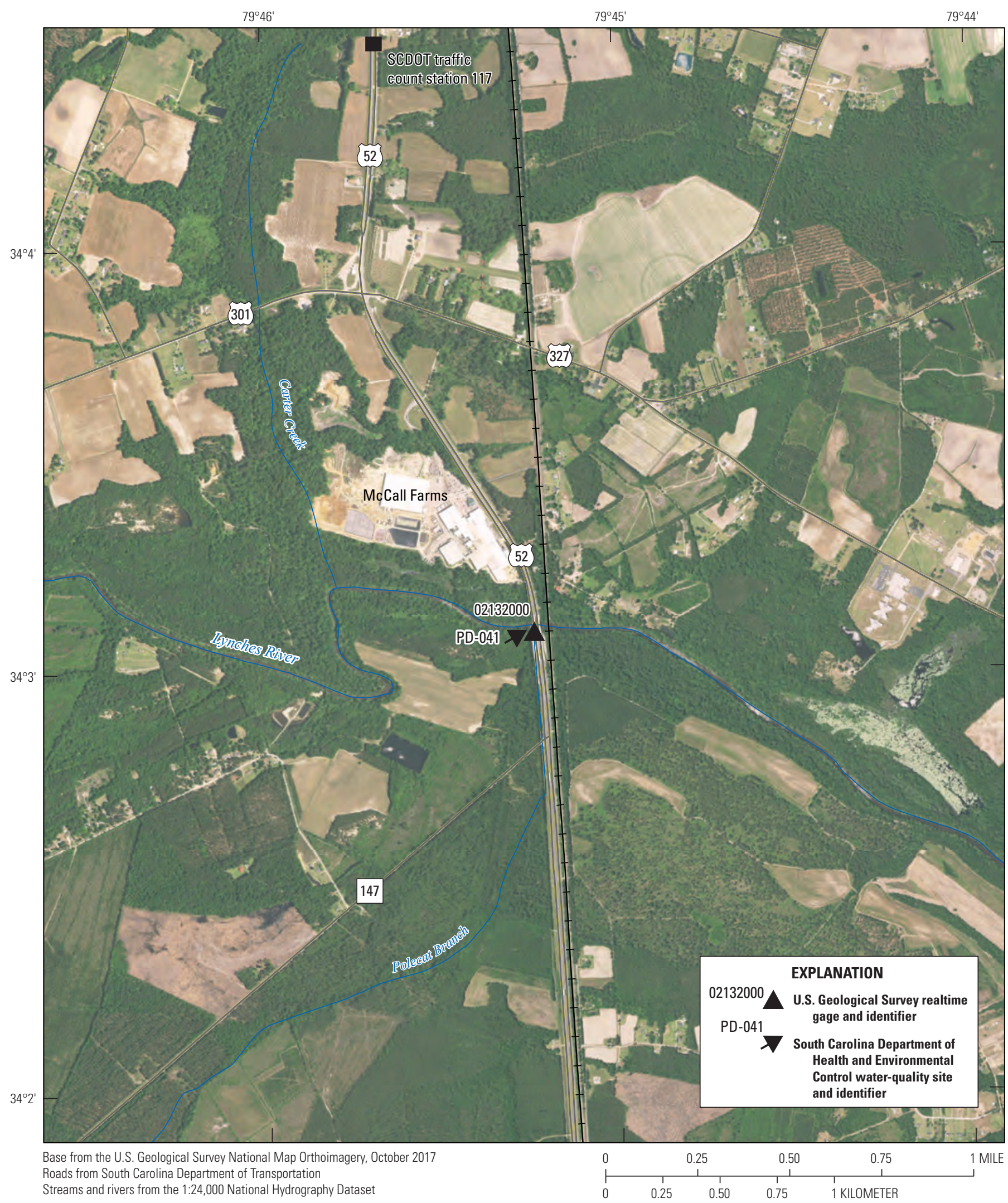

Figure 3. Map showing the bridge site on U.S. Highway 52 at the Lynches River at Effingham, South Carolina, streamflow-gaging station (U.S. Geological Survey station 02132000). 


\section{North Fork Edisto River}

The North Fork Edisto River is in the Upper Coastal Plain physiographic province (fig. 1) and, as with the Lynches River, is a blackwater system. In fact, the Edisto River that forms at the confluence of the North and South Forks is considered the longest free-flowing blackwater river in the United States.

The North Fork Edisto River at Orangeburg, S.C., streamflow-gaging station (02173500) is off U.S. Highway 601/301 (US 601/301) in Orangeburg, Orangeburg County, S.C., and the river drains an area of $683 \mathrm{mi}^{2}$ (table 1; figs. 1, 4). This station has a period of record from 1939 to present (2018). Daily streamflow at this location had a mean of $718 \mathrm{ft}^{3} / \mathrm{s}$ and ranged from 113 to $8,850 \mathrm{ft}^{3} / \mathrm{s}$ during the period of record. At the station, US 601/301 runs east-west and has a four-lane single-span bridge over the North Fork Edisto River that flows from north to south. The station is on the downstream side of the bridge on the north bank. The bridge span is $291 \mathrm{ft}$ long and $54 \mathrm{ft}$ wide.

Because of the more urbanized setting of Orangeburg, AADT counts at SCDOT Orangeburg County station 229 on US 601/301 at the bridge were 24,300, 21,000, and 22,000 in 2013, 2014, and 2015, respectively (South Carolina Department of Transportation, 2018). Stormwater drainage from the bridge deck is from evenly spaced downspouts on both edges of the deck that drain directly from the deck to the water below. Additionally, on the southern bank of the North Fork Edisto River is a boat ramp just upstream from the bridge and parking area under the bridge.

The SCDHEC monitors the water-quality conditions in the North Fork Edisto River at the SCDHEC station E-007 watershed (South Carolina Department of Health and Environmental Control, 2012a). In 2014, the SCDHEC reported that $\mathrm{pH}$ excursions occurred at this freshwater classified river but were considered typical of blackwater systems and, thus, were considered natural. However, there is concern about increasing trends in 5-day biochemical oxygen demand. Recreational uses were fully supported.

The North Fork Edisto River at the US 601/301 bridge (referred to herein as the "NFEdisto bridge site") was selected as one of the bridge sites for USGS stormwater sampling. At this site, water-quality samples (routine and storm) were collected at transects about $50 \mathrm{ft}$ upstream and $50 \mathrm{ft}$ downstream from the bridge span. Tagline supports were installed at the transects on both banks to ensure the same distance from the bridge was monitored for all samplings. Deployment of the six Hester-Dendy artificial substrate samplers, which were used for benthic macroinvertebrate community surveys, deviated slightly from the $50-\mathrm{ft}$ transects to meet habitat (for example, stream depth, velocity, and bed substrate) requirements. Streambed-sediment sampling also deviated slightly by collecting samples at multiple points within a 10 -ft zone around the upstream and downstream transects to target depositional zones, where possible.

\section{Turkey Creek}

Turkey Creek, a low-gradient blackwater tributary of Huger Creek, is within Francis Marion National Forest and part of the U.S. Department of Agriculture (USDA) Forest Service Santee Experimental Forest (fig. 5). Turkey Creek is in the Lower Coastal Plain physiographic province of South Carolina and is part of a larger system that drains to the Cooper River forming the Charleston Harbor System (Amatya and Trettin, 2008).

The Turkey Creek above Huger, S.C., streamflow-gaging station (02172035) is off S.C. Highway 41 (SC 41) north of Huger in Berkeley County, S.C., and the river drains an area of $22.7 \mathrm{mi}^{2}$ (table 1; figs. 1, 5). This station has a period of streamflow record from 2005 to present (2018). Daily mean streamflow at this location had a mean of $21.8 \mathrm{ft}^{3} / \mathrm{s}$ and ranged from 0 to $5,500 \mathrm{ft}^{3} / \mathrm{s}$ during the period of record.

At the streamflow-gaging station, SC 41 runs north-south and has a two-lane single-span bridge over Turkey Creek that flows from east to west. The station is on the downstream side of the bridge on the north bank. The bridge span is about $120 \mathrm{ft}$ long and about $44 \mathrm{ft}$ wide, covering an area of about 5,280 square feet. AADT counts at SCDOT Berkeley County station 153 on US 41 north of the bridge were 2,600 and 2,700 for 2015 and 2016, respectively (South Carolina Department of Transportation, 2018).

Turkey Creek has been studied extensively since 2005, and information has been published in several reports (Amatya and others, 2009, 2013, 2015). Hydrology, water quality, and geomorphology of Turkey Creek has been described previously in the above-referenced reports. Water-quality conditions, including nutrient levels, in Turkey Creek were characterized as being within the range of others streams with similar land use in the area (Amatya and others, 2009).

Turkey Creek at the SC 41 bridge (referred to herein as the "Turkey bridge site") was selected as one of the bridge sites for USGS stormwater sampling. At this site, waterquality profiles, streamflow measurements, and water-quality samples (routine and storm) were collected at transects about $20 \mathrm{ft}$ upstream and $50 \mathrm{ft}$ downstream from the bridge span. Tagline supports were installed at the transects on both banks to ensure the same distance from the bridge was monitored for all samplings. Two exceptions were during periods of near zero (below $1 \mathrm{ft}^{3} / \mathrm{s}$ ) flow conditions (April to June 2016; March 2017) when samples were collected from the bridge to prevent entering the stream and suspending sediment into the water column during collection. Deployment of the 14 Hester-Dendy artificial substrate samplers, which were used for benthic macroinvertebrate community surveys, deviated slightly from the 20 - and 50-ft transects to meet habitat (for example, stream depth, velocity, and bed substrate) requirements. Streambed-sediment sampling also deviated slightly by collecting samples at multiple points within a 10 -ft zone around the upstream and downstream transects to target depositional zones, where possible. 


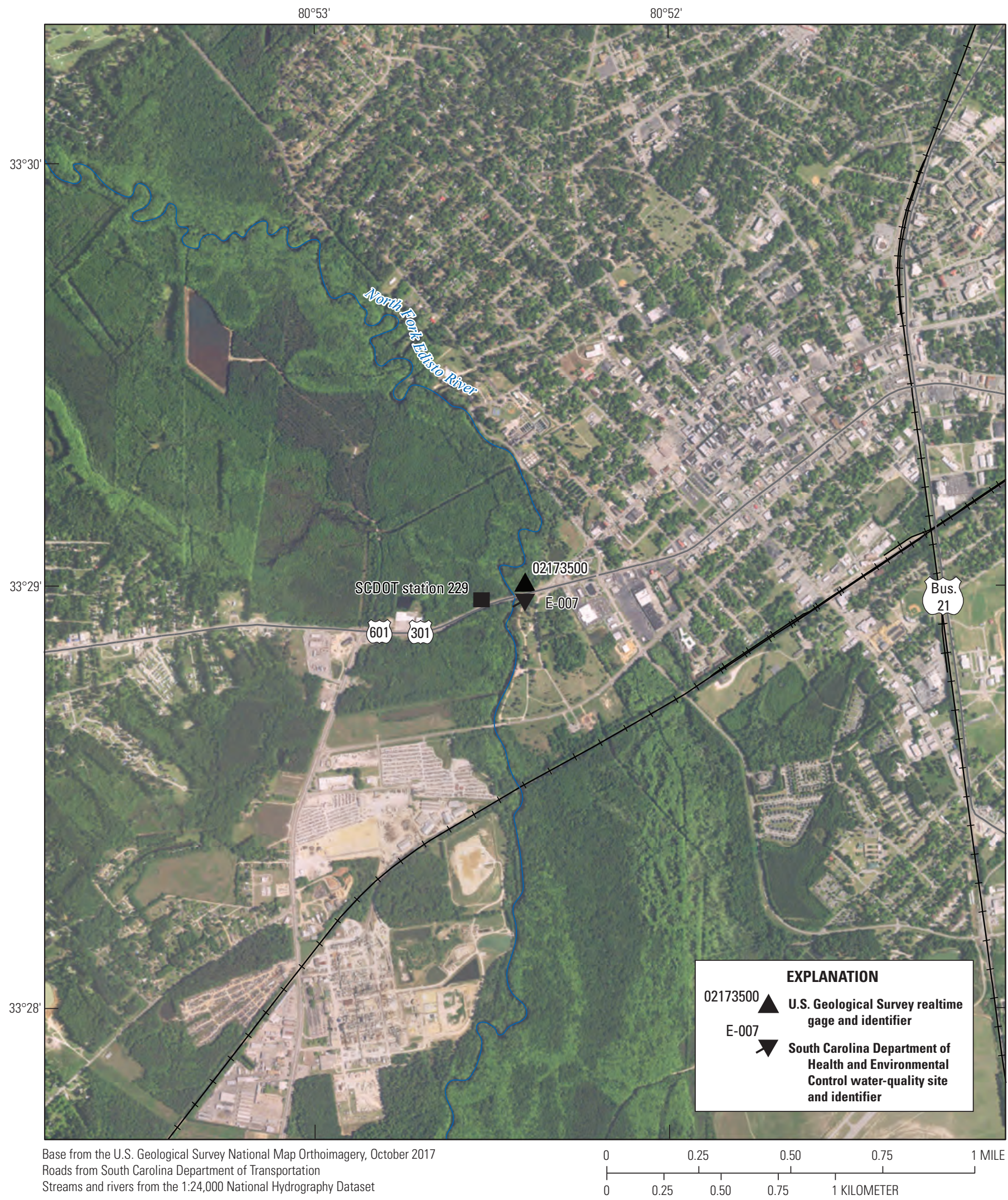

Figure 4. Map showing the bridge site on U.S. Highway 601/301 at the North Fork Edisto River at Orangeburg, South Carolina, streamflow-gaging station (U.S. Geological Survey station 02173500). 


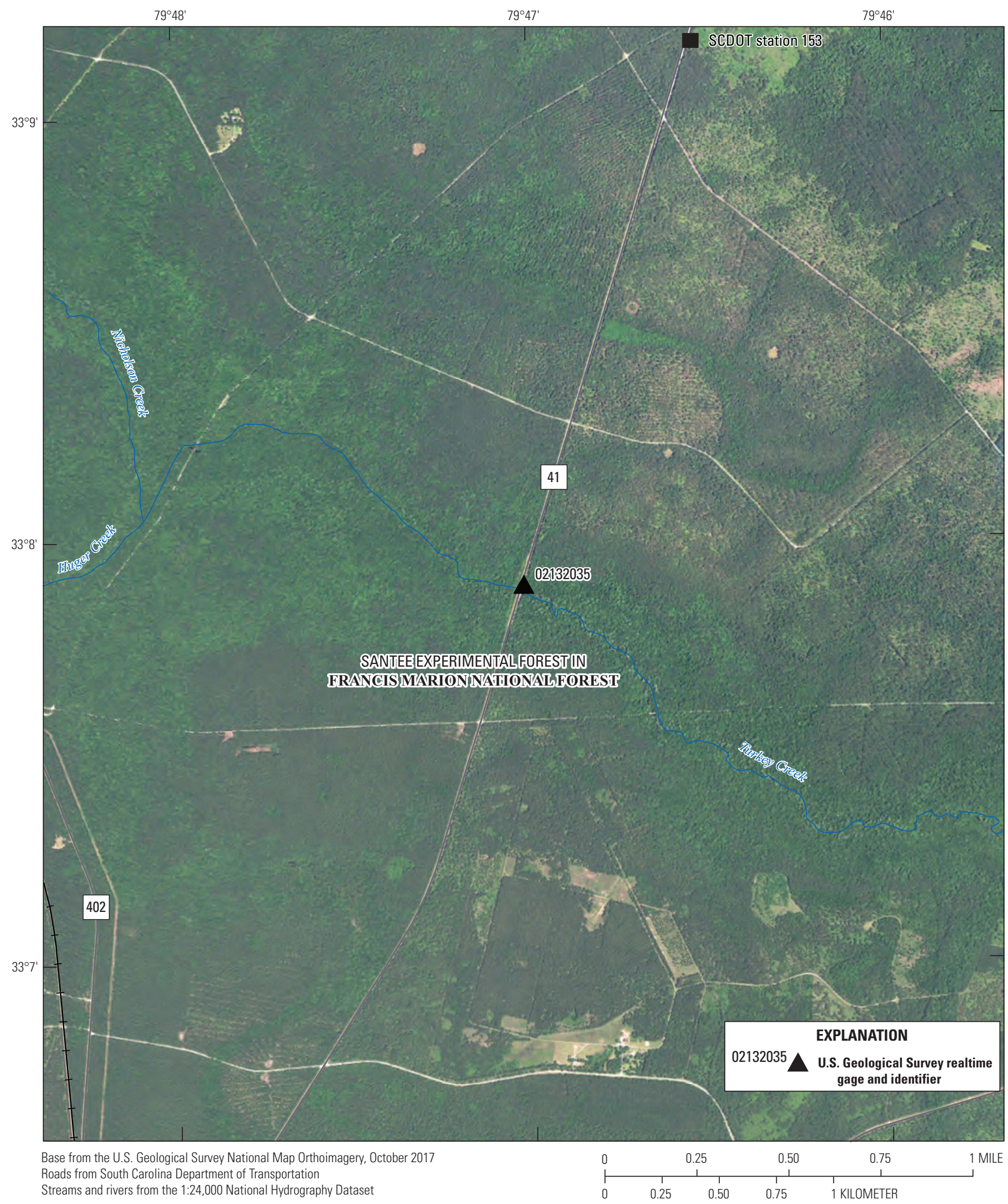

Figure 5. Map showing the bridge site on South Carolina Highway 41 at the Turkey Creek above Huger, South Carolina, streamflowgaging station (U.S. Geological Survey station 02173035). 


\section{South Fork Edisto River}

The South Fork Edisto River is in the upper Coastal Plain physiographic province (fig. 1) and is a blackwater system. The South Fork Edisto River joins with the North Fork to form the Edisto River, which is considered the longest free-flowing blackwater river in the United States.

The South Fork Edisto River near Denmark, S.C., streamflow-gaging station (02173000) is off U.S. Highway 321 (US 321) about 4.8 miles north of Denmark, Bamberg County, S.C., and the river drains an area of $720 \mathrm{mi}^{2}$ (table 1; figs. 1, 6). The station is on the left bank at the downstream side of bridge on US 321, $360 \mathrm{ft}$ downstream from Seaboard Coast Line Railroad Bridge. This station has a period of record from 1931 to present (2018). Daily mean streamflow at this location had a mean of $712 \mathrm{ft}^{3} / \mathrm{s}$ and ranged from 110 to $12,700 \mathrm{ft}^{3} / \mathrm{s}$ during the period of record. At the station location, US 321 runs north-south and has a two-lane single-span bridge over South Fork Edisto River that flows from west to east. The bridge span is $394 \mathrm{ft}$ long and $26 \mathrm{ft}$ wide.

The SCDOT monitors the AADT counts at SCDOT station 147 on US 321 and counts were 3,200 and 2,800 in 2015 and 2016, respectively (South Carolina Department of Transportation, 2018). Stormwater runoff drains from the bridge deck from evenly spaced downspouts on both edges of the deck that drain directly from the deck to the water below.

The SCDHEC monitors the water-quality conditions in the South Fork Edisto River at a location about 12 miles downstream from the USGS streamflow-gaging station: SCDHEC station E-012 (South Carolina Department of Health and Environmental Control, 2012a). In 2014, the SCDHEC reported that $\mathrm{pH}$ excursions occurred at this freshwater classified river but were considered typical of blackwater systems and, thus, were considered natural. However, there is concern about increasing trends in 5-day biochemical oxygen demand. Recreational uses were fully supported.

The South Fork Edisto River at the US 321 bridge (referred to herein as the "SFEdisto bridge site") was selected as one of the bridge sites for USGS stormwater sampling. At this site, water-quality samples (routine and storm) were collected at transects about $50 \mathrm{ft}$ upstream and $50 \mathrm{ft}$ downstream from the bridge span. Tagline supports were installed at the transects on both banks to ensure the same distance from the bridge was monitored for all sampling events. Deployment of the 14 Hester-Dendy artificial substrate samplers, which were used for benthic macroinvertebrate community surveys, deviated slightly from the $50-\mathrm{ft}$ transects to meet habitat (for example, stream depth, velocity, and bed substrate) requirements. Streambed-sediment sampling also deviated slightly by collecting samples at multiple points within a $10-\mathrm{ft}$ zone around the upstream and downstream transects to target depositional zones, where possible.

\section{Fishing Creek}

The headwater of Fishing Creek is in the Piedmont physiographic province in York County in South Carolina (fig. 1). The Fishing Creek at S.C. Highway 5 below York, S.C., streamflow-gaging station (021473415) is off S.C. Highway 5 (SC 5) about 2.7 miles east of York, York County, S.C., and the river drains an area of only $16.7 \mathrm{mi}^{2}$ (table 1; figs. 1, 7). This station has a period of record from 2008 to present (2018). Daily mean streamflow at this location had a mean of $12.3 \mathrm{ft}^{3} / \mathrm{s}$ and ranged from 0.01 to $2,910 \mathrm{ft}^{3} / \mathrm{s}$ during the period of record (table 1). At the gaging station, SC 5 runs southeast-northwest and has a two-lane single-span bridge over Fishing Creek that flows from north to south. The gaging station is on the upstream side of the bridge. The bridge span is $96 \mathrm{ft}$ long and $42 \mathrm{ft}$ wide (table 1).

Because of the more rural setting of York, AADT counts at SCDOT York County station 188 on SC 5 at the bridge were $9,000,8,900$, and 9,200 in 2016, 2017, and 2018, respectively (South Carolina Department of Transportation, 2018). Stormwater drainage from the bridge deck is from evenly spaced downspouts on both edges of the deck that drain at an angle directly from the deck to the water below.

The SCDHEC monitors the water-quality conditions in Fishing Creek, including about 3 miles downstream from the gaging station at SCDHEC station CW-005 (South Carolina Department of Health and Environmental Control, 2012b; 2014c). Past assessments by SCDHEC in the late 1990s reported elevated fecal indicator bacteria concentrations; therefore, the total maximum daily load was developed for the entire watershed (Harden, 2002). Although best management practices were implemented in 2007, the 2014 SCDHEC assessment reported that fecal indicator bacterial excursions still occurred periodically at this freshwater classified river (South Carolina Department of Health and Environmental Control, 2014c).

Fishing Creek at the SC 5 bridge (referred to herein as the "Fishing bridge site") was selected as one of the bridge sites for USGS stormwater sampling. At this site, waterquality profiles, streamflow measurements, and water-quality samples (routine and storm) were collected at transects about $35 \mathrm{ft} \mathrm{upstream}$ and $35 \mathrm{ft}$ downstream from the bridge span. Tagline supports were installed at the transects on both banks to ensure the same distance from the bridge was monitored for all sampling events. Deployment of the 14 Hester-Dendy artificial substrate samplers, which were used for benthic macroinvertebrate community surveys, deviated slightly from the 35-ft transect locations to meet habitat (for example, stream depth, velocity, and bed substrate) requirements. Streambed-sediment sampling also deviated slightly by collecting samples at multiple points within a $10-\mathrm{ft}$ zone around the upstream and downstream transects to target depositional zones, where possible. 


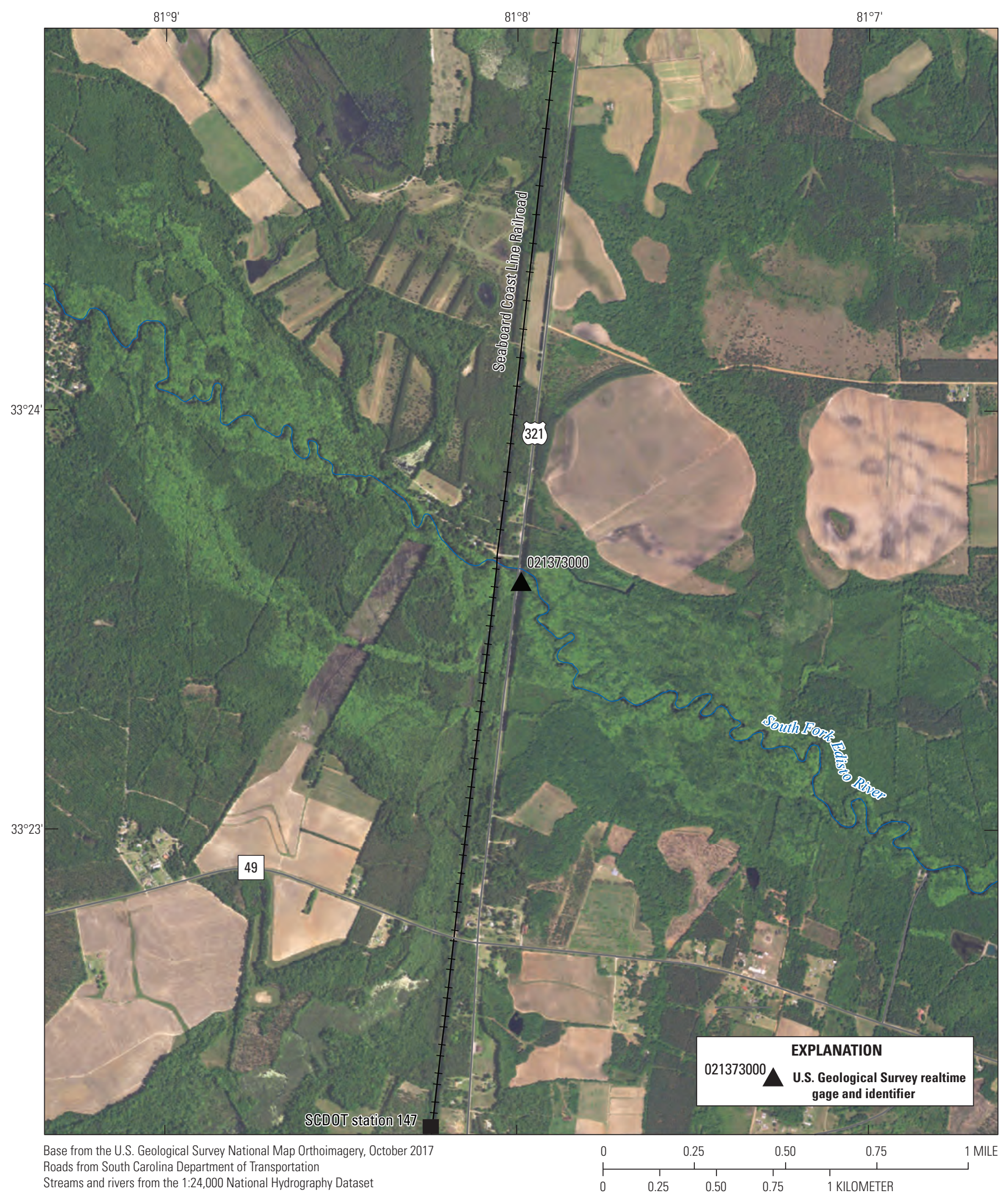

Figure 6. Map showing the bridge location on U.S. Highway 321 at the South Fork Edisto River near Denmark, South Carolina, streamflow-gaging station (U.S. Geological Survey station 02173000). 


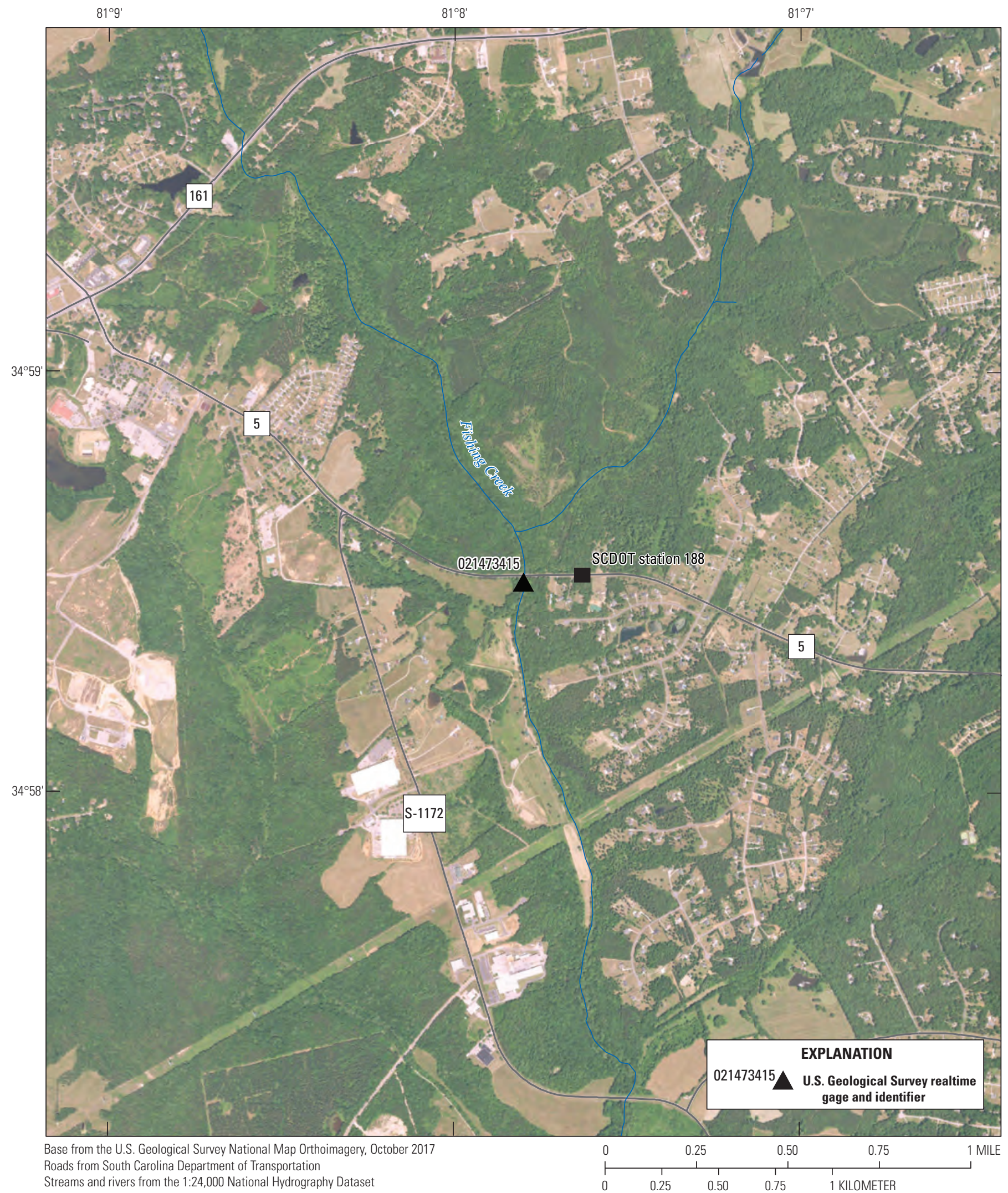

Figure 7. Map showing the bridge site on South Carolina Highway 5 at the Fishing Creek at Highway 5 below York, South Carolina, streamflow-gaging station (U.S. Geological Survey station 021473415). 


\section{Selected Bridge Site Characteristics}

Each bridge site was characterized in relation to streamflow and water quality before the beginning of storm and routine sampling. The hydrologic characterization provided information on how well the reported streamflow at the streamflow-gaging station represented the streamflow at transects upstream and downstream from the bridge. The water-quality characterization provided information on how well the stream water was mixed at the transects upstream and downstream from the bridge during periods of no stormwater runoff.

\section{Hydrologic Characteristics at Selected Bridge Sites}

Comparing streamflow from the upstream transect to the downstream transect at a bridge site was necessary to determine if streamflow increased (for example, small tributary inflows or groundwater discharge) in the intervening reach, which would affect the ability to compare constituent concentrations in the stream water between the two transects. A streamflow measurement with a level of uncertainty, because of equipment and operator limitations, of about 5 percent was considered a good measurement and adequate for the purpose of this study. If streamflow did not change in the stream reach between upstream and downstream transects, concentrations between the two locations could be directly compared without normalizing for streamflow. Streamflow was measured at the upstream and downstream transects at the five bridge sites during two to three flow conditions. Percent RSDs were computed for each measurement and compared to the rating of the measurement to determine if any differences in streamflow were observed (appendix table 2.4, available for download at https://doi.org/10.3133/sir20205046; table 7).

The Lynches bridge site had similar streamflow at upstream and downstream transects, with concurrent (within 1 hour) streamflow measurements between the two transects ranging from 0.4 to 4.0 percent RSD (within the uncertainty of the measurements). Streamflow measurement with the maximum RSD of 4.0 percent was measured $150 \mathrm{ft}$ upstream from the bridge (rather than at the established upstream transect) and included contributions from Polecat Branch. Additionally, the comparison of the streamflow measurement at transects and the streamflow from the streamflow-gaging station rating also indicated good agreement; RSDs were between 0 and 1.1 percent (table 7).

The NFEdisto bridge site also had similar streamflow between the upstream and downstream transects; measurements ranged from 0.4 to 1.7 percent RSD (well within the uncertainty of the measurements; table 7). Streamflow measurements at the transects also compared well with the streamflow from the streamflow-gaging station rating.

The Turkey bridge site had the greatest difference between streamflow at the upstream and downstream transects of all the bridge sites. Turkey RSDs of upstream and downstream streamflow were 2.4, 7.4, and 17.7 percent RSD for gaged streamflow of $2.24,7.05$, and $0.07 \mathrm{ft}^{3} / \mathrm{s}$, respectively (appendix table 2.4), which exceeded the uncertainty of the measurements. However, the RSD of 17.7 percent was from streamflow measurements of $0.09 \mathrm{ft}^{3} / \mathrm{s}$ at the upstream transect and $0.07 \mathrm{ft}^{3} / \mathrm{s}$ at the downstream transect, indicating greatest uncertainty during periods of extremely low-flow conditions $\left(0.07 \mathrm{ft}^{3} / \mathrm{s}\right.$ from the gaging station rating; appendix table 2.4). The other streamflow measurements ranged from 2.4 to 7.4 percent and were considered acceptable for the purpose of this report. Streamflow measurements at the transects also compared well with the streamflow from the streamflowgaging station rating (table 7).

The SFEdisto bridge site had similar streamflow between the upstream and downstream transects; RSDs ranged from 1.4 to 2.1 percent (within the uncertainty of the measurements; table 7). Streamflow measurements at the transects also compared well with the streamflow from the streamflowgaging station rating (appendix table 2.4).

The Fishing bridge site had differences in streamflow between the upstream and downstream transects of 2.1 to 5.4 percent RSD (within the acceptable range for this study; table 7). Streamflow measurements at the transects also compared well with the streamflow from the streamflowgaging station rating (appendix table 2.4).

Therefore, streamflows at the streamflow-gaging stations at each bridge site were used to determine streamflow at the time of sampling. Also, with similar streamflows between upstream and downstream transects, concentrations measured at the two transects were compared without any flow normalization. The Turkey bridge site was the exception, but this site had the greatest degree of uncertainty during low-flow conditions. 
Table 7. Percent relative standard deviation of streamflow between transects upstream and downstream from the five selected bridge sites and between gaged and measured streamflow at upstream transect.

[See more detailed information in appendix table 2.4. Dates shown as month/day/year. Bold values indicate that the value did not meet the data-quality criterion of less than 5 percent relative standard deviation (RSD) or streamflow difference less than 0.1 cubic foot per second for this study.

USGS, U.S. Geological Survey; ID, identifier; - , not determined]

\begin{tabular}{|c|c|c|c|c|c|}
\hline $\begin{array}{l}\text { USGS station } \\
\text { number' (fig. 1) }\end{array}$ & $\begin{array}{l}\text { Site ID } \\
\text { (table 1) }\end{array}$ & Date & $\begin{array}{l}\text { RSD between upstream } \\
\text { and downstream } \\
\text { transects (percent) }\end{array}$ & $\begin{array}{l}\text { RSD between gaged } \\
\text { and measured upstream } \\
\text { streamflow (percent) }\end{array}$ & $\begin{array}{l}\text { Rating of upstream measurement } \\
\text { (percentage of uncertainty) }\end{array}$ \\
\hline \multirow[t]{3}{*}{2132000} & Lynches & $09 / 11 / 2013$ & 4.0 & 1.0 & Fair (8) \\
\hline & & $11 / 21 / 2013$ & 2.2 & 1.1 & Good (5) \\
\hline & & $12 / 05 / 2013$ & 0.4 & 0 & Good (5) \\
\hline \multirow[t]{2}{*}{2173500} & NFEdisto & $09 / 12 / 2013$ & 0.4 & 0.4 & Good (5) \\
\hline & & $12 / 03 / 2013$ & 1.7 & 0.7 & Good (5) \\
\hline \multirow[t]{3}{*}{2172035} & Turkey & $03 / 18 / 2015$ & 7.4 & 3.7 & Very good (3) \\
\hline & & $05 / 06 / 2015$ & 2.4 & 1.3 & Very good (3) \\
\hline & & $05 / 20 / 2015$ & $17.7^{2}$ & $17.7^{2}$ & Very good (3) \\
\hline 21473415 & & 06/08/2016 & 5.4 & 6.2 & Very good (3) \\
\hline
\end{tabular}

${ }^{1}$ Station numbers are from the USGS National Water Information System database (USGS, 2016). See table 1 for station names and descriptive information.

${ }^{2}$ Difference in measurements was less than 0.1 cubic foot per second.

\section{Water-Quality Characteristics at Selected Bridge Sites}

Basic water-quality characteristics at selected bridge sites were assessed by measuring water temperature, $\mathrm{pH}, \mathrm{SC}$, and $\mathrm{DO}$ at multiple points along transects upstream and downstream from the bridge (appendix tables 3.1-3.5, available for download at https://doi.org/10.3133/sir20205046; table 8). The measurements produced a depth- and width-integrated dataset of water quality to evaluate mixing. Two to three profiles were collected at a range of flow conditions at each bridge site.

Percent RSDs were computed for each profile at each bridge site for water temperature, $\mathrm{pH}, \mathrm{DO}$, and $\mathrm{SC}$ to assess the degree of variability along the cross section and between transects (table 8). The Lynches, NFEdisto, and SFEdisto bridge sites had the lowest RSDs of the four field properties for each profile, ranging from 0.6 to 3.1 percent for DO, 0.4 to 3.5 percent for $\mathrm{pH}, 0$ to 5.6 percent for $\mathrm{SC}$, and 0.2 to 4.6 percent for water temperature. The Turkey bridge site was within the same ranges for $\mathrm{pH}, \mathrm{SC}$, and water temperature; however, during the third profile on May 20, 2015, Turkey experienced a period of extremely low flow $\left(0.07 \mathrm{ft}^{3} / \mathrm{s}\right)$ when the median DO concentration was $2.0 \mathrm{mg} / \mathrm{L}$ at the upstream transect and $1.5 \mathrm{mg} / \mathrm{L}$ at the downstream transect. During these low-flow conditions, RSD of DO was 11.9 percent, which indicated some degree of poor mixing. Similarly, the Fishing bridge site also experienced a low-flow condition $\left(0.14 \mathrm{ft}^{3} / \mathrm{s}\right)$ during the third profile on July 27, 2016, resulting in poor mixing. During this low-flow period, SC, DO, and water temperature demonstrated high RSDs of 11.7, 50.6, and 14.1 percent at the Fishing bridge site.

\section{Water Quality at Selected Bridge Sites}

Water-quality conditions were characterized at each bridge site and compared to existing SCDHEC criteria, where applicable (table 4). The data were summarized statistically in tables and graphically in boxplots. During the data-collection period for each bridge site, routine sampling of water quality during nonstorm conditions was conducted at the upstream transect (routine samples) in addition to storm sampling at both upstream and downstream transects (storm_US and storm_DS samples). Before statistical analysis, water-quality data were grouped by their sampling location. Routine and storm waterquality data were compared using permutation one-factor tests ( $\alpha$ level of 0.05 ) to assess changes in water quality from ambient conditions (routine) during storms, including when bridge-deck runoff was present in the receiving water at the downstream transects (table 9). Additionally, a more focused evaluation of differences in water-quality data from upstream to downstream (bridge-deck runoff affected) transects for each storm was conducted using a pairwise Wilcoxon signed rank test (table 10). If the $Z$ statistic was greater than 2 ( $\alpha$ level of 0.05 ), the test indicated a statistically significant downstream change in concentrations. 
Table 8. Relative standard deviation of water-quality data collected along transects upstream and downstream from the five selected bridge sites, South Carolina, 2013 to 2016.

[Dates shown as month/day/year. Bold values indicate that the value did not meet the data-quality criterion of less than 10 percent relative standard deviation (RSD). ID, identifier; ft3/s, cubic foot per second; $\mathrm{mg} / \mathrm{L}$, milligram per liter; $\mathrm{SU}$, standard unit; $\mu \mathrm{S} / \mathrm{cm}$, microsiemens per centimeter at 25 degrees Celsius; ${ }^{\circ} \mathrm{C}$, degree Celsius]

\begin{tabular}{|c|c|c|c|c|c|c|c|}
\hline \multirow[b]{2}{*}{ Site ID (table 1) } & \multirow[b]{2}{*}{ Date of profile } & \multirow[b]{2}{*}{ Site profile } & \multirow[b]{2}{*}{$\begin{array}{c}\text { Streamflow } \\
\left(\mathrm{ft}^{3} / \mathbf{s}\right)\end{array}$} & \multicolumn{4}{|c|}{ Relative standard deviation (percent) } \\
\hline & & & & $\begin{array}{l}\text { Dissolved oxygen } \\
\text { (mg/L) }\end{array}$ & $\mathrm{pH}(\mathrm{SU})$ & 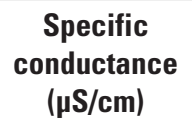 & $\begin{array}{c}\text { Water } \\
\text { temperature }\left({ }^{\circ} \mathrm{C}\right)\end{array}$ \\
\hline \multirow[t]{3}{*}{ Lynches } & $07 / 25 / 2013$ & 1 & 1,210 & 0.8 & 0.5 & 4.4 & 0.2 \\
\hline & $10 / 28 / 2013$ & 2 & 256 & 2.2 & 3.5 & 5.6 & 0.2 \\
\hline & $11 / 14 / 2013$ & 3 & 255 & 0.6 & 2.2 & 2.6 & 0.3 \\
\hline \multirow{2}{*}{ NFEdisto } & $10 / 28 / 2013$ & 2 & 317 & 1.0 & 2.1 & 0 & 0.2 \\
\hline & $11 / 13 / 2014$ & 3 & 356 & 3.1 & 1.0 & 1.4 & 4.6 \\
\hline \multirow[t]{2}{*}{ SFEdisto } & $03 / 31 / 2015$ & 1 & 800 & 1.1 & 0.7 & 0.8 & 1 \\
\hline & $04 / 28 / 2015$ & 2 & 778 & 1.1 & 1.3 & 0.7 & 0.2 \\
\hline Turkey & $05 / 20 / 2015$ & 3 & 0.07 & 11.9 & 1.5 & 0.8 & 0.9 \\
\hline \multirow[t]{3}{*}{ Fishing } & $05 / 24 / 2016$ & 1 & 4.69 & 3.0 & 0.6 & 5.2 & 4.7 \\
\hline & 06/08/2016 & 2 & 3.58 & 2.4 & 2.3 & 2.3 & 1.7 \\
\hline & $07 / 27 / 2016$ & 3 & 0.14 & 50.6 & 1.8 & 11.7 & 14.1 \\
\hline
\end{tabular}


Table 9. Results of the multiple comparison analysis using permutation one-factor test and pairwise Wilcoxon test that determined if statistically significant differences in concentrations for routine samples upstream, storm samples upstream, and storm samples downstream from the bridge at the five selected bridge sites, South Carolina, 2014 to 2018.

[Permutation one-factor test computation using the oneway test routine in coin R package with 5,000 replications was used to compute the p-value ( $\alpha>0.05 ;$ Hothorn and other, 2017). Bold and italic values indicate statistically significant test outcomes $(\alpha>0.05)$. USGS, U.S. Geological Survey; $F, F$ statistic that represents the signal to noise ratio from the one-factor test; $p$, probability value from the one-factor test; Routine, samples collected at the upstream transect during nonstorm conditions; Storm_US, samples collected at the upstream transect during storm conditions; Storm_DS, sampled collected at the downstream transect during storm conditions; $\mathrm{A}, \mathrm{B}$, and $\mathrm{C}$, locations that share the same letters are statistically similar and those that do not are statistically different (A>B $>\mathrm{C} . .$.$) determined by the Pairwise$ Wilcoxon Test $(\alpha>0.05)$; NA, not applicable; ND, not detected; 1D, one detection]

\begin{tabular}{|c|c|c|c|c|c|c|c|c|c|c|c|c|c|c|c|}
\hline \multirow{2}{*}{$\begin{array}{l}\text { Water-quality } \\
\text { constituent }\end{array}$} & \multicolumn{5}{|c|}{$\begin{array}{l}\text { Bridge site at Lynches River at Effingham, } \\
\text { South Carolina (USGS station 02132000)' }\end{array}$} & \multicolumn{5}{|c|}{$\begin{array}{l}\text { Bridge site at North Fork Edisto } \\
\text { River at Orangeburg, South Carolina } \\
\text { (USGS station 02173500) }\end{array}$} & \multicolumn{5}{|c|}{$\begin{array}{l}\text { Bridge site at Turkey Creek above Huger, } \\
\text { South Carolina (USGS station 02172035)' }\end{array}$} \\
\hline & $\boldsymbol{F}$ & $p$ & Routine & $\begin{array}{l}\text { Storm } \\
\text { US }\end{array}$ & $\begin{array}{l}\text { Storm } \\
\text { DS }\end{array}$ & $\boldsymbol{F}$ & $p$ & Routine & $\begin{array}{l}\text { Storm } \\
\text { US }\end{array}$ & $\begin{array}{l}\text { Storm } \\
\text { DS }\end{array}$ & $\boldsymbol{F}$ & $p$ & Routine & $\begin{array}{l}\text { Storm } \\
\text { US }\end{array}$ & $\begin{array}{c}\text { Storm } \\
\text { DS }\end{array}$ \\
\hline \multicolumn{16}{|c|}{ Field properties } \\
\hline Turbidity & 0.594 & 0.569 & A & A & A & 0.533 & 0.628 & A & A & A & 0.318 & 0.768 & A & A & A \\
\hline Field $\mathrm{pH}$ & 0.316 & 0.718 & A & A & A & 2.577 & 0.11 & A & A & A & 3.186 & 0.064 & A & A & A \\
\hline $\begin{array}{l}\text { Field specific } \\
\text { conductance }\end{array}$ & 0.256 & 0.779 & A & A & A & 1.244 & 0.297 & A & A & A & 2.131 & 0.133 & A & A & A \\
\hline Dissolved oxygen & 0.721 & 0.504 & A & A & A & 0.904 & 0.419 & A & A & A & 1.038 & 0.351 & A & A & $\mathrm{A}$ \\
\hline $\begin{array}{l}\text { Instantaneous } \\
\text { discharge }\end{array}$ & 0.674 & 0.52 & A & A & A & 2.656 & 0.098 & A & A & A & 0.011 & 0.98 & A & A & A \\
\hline $\begin{array}{l}\text { Acid neutralizing } \\
\text { capacity }\end{array}$ & 1.11 & 0.343 & A & A & A & 0.276 & 0.78 & A & A & A & 1.959 & 0.166 & A & A & A \\
\hline \multicolumn{16}{|c|}{ Nutrients } \\
\hline $\begin{array}{l}\text { Total organic } \\
\text { nitrogen plus } \\
\text { ammonia }\end{array}$ & 0.208 & 0.821 & A & A & A & 0.078 & 0.927 & A & A & A & 0.09 & 0.976 & A & A & A \\
\hline Total phosphorus & 0.281 & 0.751 & A & A & A & 0.010 & 0.993 & A & A & A & 0.272 & 0.862 & A & A & A \\
\hline $\begin{array}{l}\text { Dissolved nitrite } \\
\text { plus nitrate }\end{array}$ & 0.219 & 0.816 & A & A & A & 0.029 & 0.972 & A & $\mathrm{A}$ & A & 1.532 & 0.079 & A & A & A \\
\hline Total nitrogen & 0.131 & 0.875 & A & A & A & 0.162 & 0.844 & A & A & A & 0.108 & 0.968 & A & A & A \\
\hline \multicolumn{16}{|c|}{ Major ions and sediment } \\
\hline Total hardness & 0.07 & 0.927 & A & A & A & 0.377 & 0.707 & A & A & A & 1.669 & 0.194 & A & A & A \\
\hline Dissolved chloride & 0.058 & 0.953 & A & A & A & 3.66 & 0.04 & $\mathrm{~B}$ & A & A & 4.723 & 0.020 & $\mathrm{~B}$ & A & A \\
\hline $\begin{array}{l}\text { Suspended } \\
\text { sediment } \\
\text { concentration }\end{array}$ & 0.038 & 0.953 & A & A & A & 0.898 & 0.456 & A & A & A & 0.233 & 0.806 & A & A & A \\
\hline $\begin{array}{l}\text { Suspended sediment } \\
\text { as percent finer } \\
\text { than sand }\end{array}$ & 0.427 & 0.692 & A & A & A & 1.098 & 0.357 & A & A & A & 0.062 & 0.939 & A & A & A \\
\hline
\end{tabular}


Table 9. Results of the multiple comparison analysis using permutation one-factor test and pairwise Wilcoxon test that determined if statistically significant differences in concentrations for routine samples upstream, storm samples upstream, and storm samples downstream from the bridge at the five selected bridge sites, South Carolina, 2014 to 2018.-Continued

[Permutation one-factor test computation using the oneway_test routine in coin R package with 5,000 replications was used to compute the p-value ( $\alpha>0.05$; Hothorn and other, 2017). Bold and italic values indicate statistically significant test outcomes $(\alpha>0.05)$. USGS, U.S. Geological Survey; $F, F$ statistic that represents the signal to noise ratio from the one-factor test; $p$, probability value from the one-factor test; Routine, samples collected at the upstream transect during nonstorm conditions; Storm US, samples collected at the upstream transect during storm conditions; Storm DS, sampled collected at the downstream transect during storm conditions; $\mathrm{A}, \mathrm{B}$, and $\mathrm{C}$, locations that share the same letters are statistically similar and those that do not are statistically different $(\mathrm{A}>\mathrm{B}>\mathrm{C} . .$.$) determined by the Pairwise$ Wilcoxon Test $(\alpha>0.05)$; NA, not applicable; ND, not detected; 1D, one detection]

\begin{tabular}{|c|c|c|c|c|c|c|c|c|c|c|c|c|c|c|c|}
\hline \multirow{2}{*}{$\begin{array}{l}\text { Water-quality } \\
\text { constituent }\end{array}$} & \multicolumn{5}{|c|}{$\begin{array}{l}\text { Bridge site at Lynches River at Effingham, } \\
\text { South Carolina (USGS station 02132000)1 }\end{array}$} & \multicolumn{5}{|c|}{$\begin{array}{l}\text { Bridge site at North Fork Edisto } \\
\text { River at Orangeburg, South Carolina } \\
\text { (USGS station 02173500) }\end{array}$} & \multicolumn{5}{|c|}{$\begin{array}{l}\text { Bridge site at Turkey Creek above Huger, } \\
\text { South Carolina (USGS station 02172035)' }\end{array}$} \\
\hline & $\boldsymbol{F}$ & $p$ & Routine & $\begin{array}{l}\text { Storm } \\
\text { US }\end{array}$ & $\begin{array}{l}\text { Storm_- } \\
\text { DS }\end{array}$ & $F$ & $p$ & Routine & $\begin{array}{l}\text { Storm_- } \\
\text { US }\end{array}$ & $\begin{array}{l}\text { Storm } \\
\text { DS }\end{array}$ & $\boldsymbol{F}$ & $\boldsymbol{p}$ & Routine & $\begin{array}{l}\text { Storm } \\
\text { US }\end{array}$ & $\begin{array}{l}\text { Storm } \\
\text { DS }\end{array}$ \\
\hline \multicolumn{16}{|c|}{ Bacteria } \\
\hline Escherichia coli & 1.726 & 0.215 & A & A & A & 0.522 & 0.499 & A & A & A & 0.037 & 0.991 & A & A & A \\
\hline \multicolumn{16}{|c|}{ Dissolved metals } \\
\hline Cadmium, filtered & NA & NA & ND & ND & ND & NA & NA & ND & ND & ND & NA & NA & ND & ND & ND \\
\hline Chromium, filtered & 0.349 & 0.709 & A & $\mathrm{A}$ & $\mathrm{A}$ & 1.091 & 0.313 & A & A & A & 0.009 & 0.99 & A & A & A \\
\hline Copper, filtered & 0.672 & 0.526 & A & A & A & 1.24 & 0.087 & $\mathrm{~A}$ & $\mathrm{~A}$ & $\mathrm{~A}$ & 0.113 & 0.898 & A & $\mathrm{A}$ & A \\
\hline Lead, filtered & 0.718 & 0.494 & A & A & A & 0.232 & 0.797 & A & A & A & 1.54 & 0.232 & A & A & A \\
\hline Mercury, filtered & 1.44 & 0.258 & A & A & A & 0.281 & 0.713 & A & $\mathrm{A}$ & A & 0.107 & 0.916 & A & A & A \\
\hline Zinc, filtered & 0.558 & 0.571 & A & A & A & 1.32 & 0.268 & A & A & A & 5.76 & 0.013 & B & A & A \\
\hline Arsenic, filtered & 1.38 & 0.28 & A & A & A & 1.203 & 0.318 & A & A & A & 0.002 & 0.998 & A & A & A \\
\hline Selenium, filtered & 0.311 & 0.736 & A & A & A & 0.347 & 0.708 & A & $\mathrm{A}$ & A & 0.374 & 0.035 & $\mathrm{~B}$ & A & A \\
\hline \multicolumn{16}{|c|}{ Total recoverable metals } \\
\hline Cadmium, total & NA & NA & ND & ND & ND & NA & NA & ND & ND & ND & NA & NA & ND & ND & ND \\
\hline Chromium, total & 1.176 & 0.337 & A & A & A & 0.564 & 0.645 & $\mathrm{~A}$ & A & A & 0.716 & 0.467 & $\mathrm{~A}$ & A & A \\
\hline Copper, total & 0.025 & 0.975 & A & A & A & 0.408 & 0.458 & A & A & A & 0.083 & 0.989 & A & A & A \\
\hline Lead, total & 0.515 & 0.605 & A & A & A & 1.858 & 0.178 & A & A & A & 1.230 & 0.308 & A & A & A \\
\hline Mercury, total & 0.497 & 0.642 & A & A & A & 0.221 & 0.851 & A & A & A & 2.144 & 0.142 & A & A & A \\
\hline Zinc, total & 1.208 & 0.327 & A & A & A & 1.041 & 0.382 & A & $\mathrm{A}$ & A & 1.040 & 0.393 & $\mathrm{~A}$ & A & A \\
\hline Arsenic, total & 1.810 & 0.198 & A & A & A & 0.608 & 0.547 & A & A & A & 0.235 & 0.842 & A & $\mathrm{A}$ & A \\
\hline Selenium, total & 1.309 & 0.291 & $\mathrm{~A}$ & A & A & 1.77 & NA & $1 \mathrm{D}$ & $1 \mathrm{D}$ & $1 \mathrm{D}$ & 0.373 & 0.521 & $\mathrm{~A}$ & A & $\mathrm{A}$ \\
\hline
\end{tabular}


Table 9. Results of the multiple comparison analysis using permutation one-factor test and pairwise Wilcoxon test that determined if statistically significant differences in concentrations for routine samples upstream, storm samples upstream, and storm samples downstream from the bridge at the five selected bridge sites, South Carolina, 2014 to 2018.-Continued

[Permutation one-factor test computation using the oneway test routine in coin R package with 5,000 replications was used to compute the p-value ( $\alpha>0.05$; Hothorn and other, 2017). Bold and italic values indicate statistically significant test outcomes $(\alpha>0.05)$. USGS, U.S. Geological Survey; $F, F$ statistic that represents the signal to noise ratio from the one-factor test; $p$, probability value from the one-factor test; Routine, samples collected at the upstream transect during nonstorm conditions; Storm_US, samples collected at the upstream transect during storm conditions; Storm_DS, sampled collected at the downstream transect during storm conditions; $\mathrm{A}, \mathrm{B}$, and $\mathrm{C}$, locations that share the same letters are statistically similar and those that do not are statistically different (A>B $>\mathrm{C} . .$.$) determined by the Pairwise$ Wilcoxon Test $(\alpha>0.05)$; NA, not applicable; ND, not detected; 1D, one detection]

\begin{tabular}{|c|c|c|c|c|c|c|c|c|c|c|}
\hline \multirow[t]{2}{*}{ Water-quality constituent } & \multicolumn{5}{|c|}{$\begin{array}{l}\text { Bridge site at South Fork Edisto River near Denmark, South Carolina } \\
\qquad \text { (USGS station 02173000) }\end{array}$} & \multicolumn{5}{|c|}{$\begin{array}{l}\text { Bridge site at Fishing Creek at Highway } 5 \text { below York, South Carolina } \\
\text { (USGS station 021473415) }\end{array}$} \\
\hline & $F$ & $p$ & Routine & Storm_US & Storm_DS & $\boldsymbol{F}$ & $p$ & Routine & Storm_US & Storm_DS \\
\hline \multicolumn{11}{|c|}{ Field properties } \\
\hline Turbidity & 0.505 & 0.619 & A & $\mathrm{A}$ & $\mathrm{A}$ & 1.902 & 0.155 & $\mathrm{~A}$ & $\mathrm{~A}$ & $\mathrm{~A}$ \\
\hline Field pH & 2.067 & 0.149 & A & A & $\mathrm{A}$ & 0.866 & 0.429 & $\mathrm{~A}$ & $\mathrm{~A}$ & $\mathrm{~A}$ \\
\hline Field specific conductance & 0.729 & 0.472 & $\mathrm{~A}$ & $\mathrm{~A}$ & $\mathrm{~A}$ & 0.582 & 0.552 & $\mathrm{~A}$ & $\mathrm{~A}$ & $\mathrm{~A}$ \\
\hline Dissolved oxygen & 0.204 & 0.818 & A & $\mathrm{A}$ & $\mathrm{A}$ & 0.830 & 0.454 & A & $\mathrm{A}$ & $\mathrm{A}$ \\
\hline Instantaneous discharge & 0.136 & 0.877 & A & A & A & 0.288 & 0.778 & A & A & A \\
\hline Acid neutralizing capacity & 0.26 & 0.772 & A & A & $\mathrm{A}$ & 0.132 & 0.868 & A & $\mathrm{A}$ & $\mathrm{A}$ \\
\hline \multicolumn{11}{|c|}{ Nutrients } \\
\hline $\begin{array}{l}\text { Total organic nitrogen plus } \\
\text { ammonia }\end{array}$ & 0.072 & 0.939 & A & A & A & 1.758 & 0.195 & A & A & A \\
\hline Total phosphorus & 0.133 & 0.883 & A & A & $\mathrm{A}$ & 1.768 & 0.197 & A & A & $\mathrm{A}$ \\
\hline Dissolved nitrite plus nitrate & 0.252 & 0.764 & A & A & $\mathrm{A}$ & 1.180 & 0.331 & A & A & A \\
\hline Total nitrogen & 0.015 & 0.985 & A & A & $\mathrm{A}$ & 1.030 & 0.371 & $\mathrm{~A}$ & $\mathrm{~A}$ & A \\
\hline \multicolumn{11}{|c|}{ Major ions and sediment } \\
\hline Total hardness & 0.454 & 0.653 & A & A & A & 0.135 & 0.875 & A & A & A \\
\hline Dissolved chloride & 1.061 & 0.399 & A & A & $\mathrm{A}$ & 1.055 & 0.361 & A & A & A \\
\hline $\begin{array}{l}\text { Suspended sediment } \\
\text { concentration }\end{array}$ & 0.278 & 0.753 & A & A & A & 0.386 & 0.755 & A & $\mathrm{A}$ & $\mathrm{A}$ \\
\hline $\begin{array}{l}\text { Suspended sediment as } \\
\text { percent finer than sand }\end{array}$ & 0.072 & 0.934 & A & A & A & 0.042 & 0.982 & A & A & A \\
\hline \multicolumn{11}{|c|}{ Bacteria } \\
\hline Escherichia coli & 1.020 & 0.388 & A & A & A & 0.072 & 0.931 & A & A & A \\
\hline
\end{tabular}


Table 9. Results of the multiple comparison analysis using permutation one-factor test and pairwise Wilcoxon test that determined if statistically significant differences in concentrations for routine samples upstream, storm samples upstream, and storm samples downstream from the bridge at the five selected bridge sites, South Carolina, 2014 to 2018. - Continued

[Permutation one-factor test computation using the oneway_test routine in coin R package with 5,000 replications was used to compute the p-value ( $\alpha>0.05$; Hothorn and other, 2017). Bold and italic values indicate statistically significant test outcomes $(\alpha>0.05)$. USGS, U.S. Geological Survey; $F, F$ statistic that represents the signal to noise ratio from the one-factor test; $p$, probability value from the one-factor test; Routine, samples collected at the upstream transect during nonstorm conditions; Storm US, samples collected at the upstream transect during storm conditions; Storm DS, sampled collected at the downstream transect during storm conditions; A, B, and C, locations that share the same letters are statistically similar and those that do not are statistically different (A>B $>C$...) determined by the Pairwise Wilcoxon Test $(\alpha>0.05)$; NA, not applicable; ND, not detected; 1D, one detection]

\begin{tabular}{|c|c|c|c|c|c|c|c|c|c|c|}
\hline \multirow[t]{2}{*}{ Water-quality constituent } & \multicolumn{5}{|c|}{$\begin{array}{l}\text { Bridge site at South Fork Edisto River near Denmark, South Carolina } \\
\qquad \text { (USGS station 02173000) }\end{array}$} & \multicolumn{5}{|c|}{$\begin{array}{l}\text { Bridge site at Fishing Creek at Highway } 5 \text { below York, South Carolina } \\
\text { (USGS station 021473415) }{ }^{1}\end{array}$} \\
\hline & $\boldsymbol{F}$ & $p$ & Routine & Storm_US & Storm_DS & $\boldsymbol{F}$ & $p$ & Routine & Storm_US & Storm_DS \\
\hline \multicolumn{11}{|c|}{ Dissolved metals } \\
\hline Cadmium, filtered & NA & NA & ND & ND & ND & NA & NA & ND & ND & ND \\
\hline Chromium, filtered & 0.02 & 0.98 & A & A & A & 0.393 & 0.448 & A & A & A \\
\hline Copper, filtered & 0.606 & 0.447 & A & A & A & 0.037 & 0.962 & A & A & $\mathrm{A}$ \\
\hline Lead, filtered & 0.112 & 0.895 & A & A & A & 0.424 & 0.647 & A & A & $\mathrm{A}$ \\
\hline Mercury, filtered & 0.722 & 0.422 & A & A & $\mathrm{A}$ & NA & NA & ND & ND & ND \\
\hline Zinc, filtered & 0.717 & 0.418 & $\mathrm{~A}$ & A & A & 0.393 & 0.453 & A & A & A \\
\hline Arsenic, filtered & 0.116 & 0.893 & A & $\mathrm{A}$ & $\mathrm{A}$ & 1.515 & 0.246 & A & A & A \\
\hline Selenium, filtered & 0.516 & 0.595 & A & A & A & 1.839 & 0.158 & A & A & A \\
\hline \multicolumn{11}{|c|}{ Total recoverable metals } \\
\hline Cadmium, total & NA & NA & ND & ND & ND & NA & NA & ND & ND & ND \\
\hline Chromium, total & 0.902 & 0.43 & A & A & A & 1.100 & 0.348 & A & A & A \\
\hline Copper, total & 0.337 & 0.426 & A & A & A & 0.756 & 0.489 & A & A & A \\
\hline Lead, total & 0.666 & 0.523 & A & A & A & 1.804 & 0.167 & $\mathrm{~A}$ & $\mathrm{~A}$ & $\mathrm{~A}$ \\
\hline Mercury, total & 1.624 & 0.221 & A & A & A & NA & NA & $1 \mathrm{D}$ & $1 \mathrm{D}$ & $1 \mathrm{D}$ \\
\hline Zinc, total & 0.020 & 0.996 & A & A & A & 3.74 & 0.015 & $\mathrm{~B}$ & $\mathrm{AB}$ & A \\
\hline Arsenic, total & 0.464 & 0.626 & $\mathrm{~A}$ & A & A & 1.138 & 0.330 & A & A & A \\
\hline Selenium, total & 0.902 & 0.391 & $\mathrm{~A}$ & $\mathrm{~A}$ & $\mathrm{~A}$ & 2.153 & 0.136 & A & A & A \\
\hline
\end{tabular}

${ }^{1}$ Station numbers and names are from the USGS National Water Information System database (USGS, 2016). See figure 1 for locations 
Table 10. Results of the Wilcoxon one-sided signed rank test to determine if statistically greater constituent concentrations existed at transects downstream compared to upstream from the bridge during storms at the five selected bridge sites, South Carolina, 2014 to 2018.

[Bold values indicate statistically significant outcome. Used wilcoxsign_test routine in the R package coin (Hothorn and others, 2017); USGS, U.S. Geological Survey; $Z$, standardized test statistic; $p$-value, probability value; ND, not detected]

\begin{tabular}{|c|c|c|c|c|c|c|c|c|c|c|}
\hline \multirow[t]{2}{*}{ Water quality constituent } & \multicolumn{2}{|c|}{$\begin{array}{l}\text { Bridge site at Lynches } \\
\text { River at Effingham, } \\
\text { South Carolina } \\
\text { (USGS station 02132000)' }\end{array}$} & \multicolumn{2}{|c|}{$\begin{array}{l}\text { Bridge site at North Fork Edisto } \\
\text { River at Orangeburg, South Carolina } \\
\text { (USGS station 02173500) }\end{array}$} & \multicolumn{2}{|c|}{$\begin{array}{l}\text { Bridge site at Turkey } \\
\text { Creek above Huger, } \\
\text { South Carolina } \\
\text { (USGS station 02172035) }^{1}\end{array}$} & \multicolumn{2}{|c|}{$\begin{array}{l}\text { Bridge site at South } \\
\text { Fork Edisto River near } \\
\text { Denmark, South Carolina } \\
\text { (USGS station 02173000)' }^{1}\end{array}$} & \multicolumn{2}{|c|}{$\begin{array}{l}\text { Bridge site at Fishing } \\
\text { Creek at Highway } 5 \text { below } \\
\text { York, South Carolina } \\
\text { (USGS station 021473415) }^{1}\end{array}$} \\
\hline & Zstatistic & $p$-value & Zstatistic & $p$-value & Zstatistic & $p$-value & Zstatistic & $p$-value & Zstatistic & $p$-value \\
\hline \multicolumn{11}{|c|}{ Field properties } \\
\hline Water temperature & -1.000 & 1.000 & -0.686 & 0.877 & -0.71 & 0.88 & -1.414 & 1.000 & 1.626 & 0.093 \\
\hline Field specific conductance & -1.914 & 1.000 & 0.128 & 0.496 & -0.284 & 0.63 & 1.732 & 0.120 & 0.749 & 0.371 \\
\hline Turbidity & 0.405 & 0.400 & 0.734 & 0.277 & -1.361 & 0.94 & -0.817 & 0.808 & 2.023 & 0.032 \\
\hline Field pH & -0.957 & 0.876 & 1.997 & 0.029 & -0.271 & 0.617 & 1.753 & 0.061 & 0.544 & 0.375 \\
\hline \multicolumn{11}{|c|}{ Nutrients } \\
\hline $\begin{array}{l}\text { Total organic nitrogen } \\
\text { plus ammonia }\end{array}$ & -0.544 & 0.748 & 0.524 & 0.352 & 0.405 & 0.401 & 0.674 & 0.305 & 2.023 & 0.032 \\
\hline Total phosphorus & -0.544 & 0.747 & -0.734 & 0.777 & -0.820 & 0.811 & 1.511 & 0.127 & 0.944 & 0.213 \\
\hline $\begin{array}{l}\text { Dissolved nitrite plus } \\
\text { nitrate }\end{array}$ & -1.210 & 0.907 & -1.363 & 0.919 & -1.000 & 1.000 & -1.289 & 0.942 & -0.156 & 0.758 \\
\hline Total nitrogen & -0.944 & 0.838 & -0.734 & 0.780 & -0.137 & 0.633 & 0.365 & 0.437 & 2.023 & $\mathbf{0 . 0 3 0}$ \\
\hline \multicolumn{11}{|l|}{ Major ions and sediment } \\
\hline Total hardness & -0.813 & 0.809 & 0.843 & 0.252 & -1.214 & 0.900 & -0.405 & 0.683 & -2.023 & 1.000 \\
\hline Dissolved chloride & -2.023 & 1.000 & 0.213 & 0.505 & 0.566 & 0.371 & -0.156 & 0.757 & 0.135 & 0.502 \\
\hline $\begin{array}{l}\text { Suspended sediment } \\
\text { concentration }\end{array}$ & 1.109 & 0.252 & 0.137 & 0.495 & 0.921 & 0.248 & -0.711 & 0.871 & 0.552 & 0.369 \\
\hline $\begin{array}{l}\text { Suspended sediment as } \\
\text { percent finer than sand }\end{array}$ & -0.137 & 0.631 & -1.361 & 0.94 & 0.365 & 0.438 & -0.272 & 0.621 & 1.461 & 0.124 \\
\hline \multicolumn{11}{|c|}{ Bacteria } \\
\hline $\begin{array}{l}\text { Escherichia coli concen- } \\
\text { tration }\end{array}$ & 0.405 & 0.407 & 2.108 & 0.031 & 1.483 & 0.092 & -0.135 & 0.596 & 0.405 & 0.396 \\
\hline $\begin{array}{l}\text { Total coliform concentra- } \\
\text { tions }\end{array}$ & -1.483 & 0.940 & -1.294 & 0.940 & 0.135 & 0.497 & 0.674 & 0.313 & -0.272 & 0.626 \\
\hline
\end{tabular}


Table 10. Results of the Wilcoxon one-sided signed rank test to determine if statistically greater constituent concentrations existed at transects downstream compared to upstream from the bridge during storms at the five selected bridge sites, South Carolina, 2014 to 2018. - Continued

[Bold values indicate statistically significant outcome. Used wilcoxsign_test routine in the R package coin (Hothorn and others, 2017); USGS, U.S. Geological Survey; $Z$, standardized test statistic; $p$-value, probability value; $\mathrm{ND}$, not detected]

\begin{tabular}{|c|c|c|c|c|c|c|c|c|c|c|}
\hline \multirow[t]{2}{*}{ Water quality constituent } & \multicolumn{2}{|c|}{$\begin{array}{l}\text { Bridge site at Lynches } \\
\text { River at Effingham, } \\
\text { South Carolina } \\
\text { (USGS station 02132000) }^{1}\end{array}$} & \multicolumn{2}{|c|}{$\begin{array}{l}\text { Bridge site at North Fork Edisto } \\
\text { River at Orangeburg, South Carolina } \\
\text { (USGS station 02173500) }\end{array}$} & \multicolumn{2}{|c|}{$\begin{array}{l}\text { Bridge site at Turkey } \\
\text { Creek above Huger, } \\
\text { South Carolina } \\
\text { (USGS station 02172035) }^{1}\end{array}$} & \multicolumn{2}{|c|}{$\begin{array}{l}\text { Bridge site at South } \\
\text { Fork Edisto River near } \\
\text { Denmark, South Carolina } \\
\text { (USGS station 02173000) }^{1}\end{array}$} & \multicolumn{2}{|c|}{$\begin{array}{l}\text { Bridge site at Fishing } \\
\text { Creek at Highway } 5 \text { below } \\
\text { York, South Carolina } \\
\text { (USGS station 021473415) }^{1}\end{array}$} \\
\hline & Z statistic & $p$-value & Z statistic & $p$-value & Zstatistic & $p$-value & $Z$ statistic & $p$-value & Z statistic & $p$-value \\
\hline \multicolumn{11}{|c|}{ Dissolved metals } \\
\hline Cadmium, filtered & ND & ND & ND & ND & ND & ND & ND & ND & ND & ND \\
\hline Chromium, filtered & -0.283 & 0.631 & -0.128 & 0.753 & 0.962 & 0.258 & \multicolumn{2}{|c|}{ Pairwise $=$ zero for all } & \multicolumn{2}{|c|}{ Pairwise $=$ zero for all } \\
\hline Copper, filtered & 0.684 & 0.315 & -0.128 & 0.745 & 1.406 & 0.256 & -1.000 & 1.000 & 0.813 & 0.245 \\
\hline Lead, filtered & -1.697 & 1.000 & 0.314 & 0.430 & 0.813 & 0.250 & -0.944 & 0.843 & -0.135 & 0.591 \\
\hline Mercury, filtered & 1.000 & 0.504 & Pairwise $=$ zero for all & & 0.156 & 0.494 & \multicolumn{2}{|c|}{ Pairwise $=$ zero for all } & \multicolumn{2}{|c|}{ Pairwise $=$ zero for all } \\
\hline Zinc, filtered & -1.089 & 0.877 & -1.078 & 0.873 & 1.000 & 0.502 & \multicolumn{2}{|c|}{ Pairwise $=$ zero for all } & \multicolumn{2}{|c|}{ Pairwise $=$ zero for all } \\
\hline Arsenic, filtered & -1.914 & 1.000 & 0.946 & 0.206 & -0.817 & 0.815 & -2.023 & 1.000 & -2.032 & 1.000 \\
\hline Selenium, filtered & -0.817 & 0.811 & -0.943 & 0.837 & -1.490 & 0.938 & -1.214 & 0.906 & 0.544 & 0.382 \\
\hline \multicolumn{11}{|c|}{ Total recoverable metals } \\
\hline Cadmium, total & ND & ND & ND & ND & ND & ND & ND & ND & ND & ND \\
\hline Chromium, total & -0.283 & 0.622 & 1.71 & 0.131 & 2.023 & 0.030 & 0.544 & 0.376 & 0.849 & 0.248 \\
\hline Copper, total & -0.820 & 0.812 & ND & ND & 0.820 & 0.244 & \multicolumn{2}{|c|}{ Pairwise $=$ zero for all } & 1.214 & 0.163 \\
\hline Lead, total & -0.566 & 0.753 & 1.378 & 0.128 & 1.084 & 0.189 & -0.135 & 0.595 & 1.214 & 0.159 \\
\hline Mercury, total & -1.000 & 1.000 & 1.000 & 0.498 & 0.547 & 0.377 & -2.060 & 1.000 & 1.000 & 0.51 \\
\hline Zinc, total & -0.566 & 0.753 & -1.709 & 1.000 & 1.697 & 0.125 & 1.406 & 0.246 & 1.406 & 0.252 \\
\hline Arsenic, total & -0.405 & 0.683 & -0.211 & 0.624 & -0.405 & 0.688 & -0.135 & 0.591 & 0.405 & 0.411 \\
\hline Selenium, total & -0.544 & 0.747 & 1.000 & 0.502 & -0.674 & 0.785 & -1.697 & 1.000 & 0.271 & 0.439 \\
\hline
\end{tabular}

${ }^{1}$ Station numbers and names are from the U.S. Geological Survey National Water Information System (U.S. Geological Survey, 2016). See figure 1 for locations. 


\section{Lynches River}

In total, 14 routine and 10 storm samples were collected from Lynches River at the Lynches bridge site from January 2014 to March 2015 (background E. coli routine only from July 2013 to November 2013; table 3, appendix table 3.1; Romanok and others, 2020). Streamflow varied 10-fold from 216 to 2,660 $\mathrm{ft}^{3} / \mathrm{s}$ at the time of storm sampling (table 2; fig. $8 A$; appendix table 3.1) and from 144 to $2,350 \mathrm{ft}^{3} / \mathrm{s}$ at the time of routine sampling (fig. $8 A$; appendix table 3.1). The range in sampled flow conditions did a good job of capturing the period-of-record range in daily flow at this bridge site (69.4 to $24,500 \mathrm{ft}^{3} / \mathrm{s}$; tables 1,2$)$. Precipitation at the Lynches bridge site was only in the form of rainfall during the period of study. Rainfall amounts of the sampled storms ranged from 0.01 to 0.25 inch (in.) with intensities that ranged from 0.05 to 1.07 inches per hour (in/hr; table 2; fig. 8B). Antecedent rainfall conditions ranged from 1 to 17 days. The mean potential bridge-deck runoff rate (bridge discharge) for each storm was estimated to range from 0.033 to $0.647 \mathrm{ft}^{3} / \mathrm{s}$, which represents a ratio of bridge-deck runoff rate to streamflow of 0.003 to 0.19 percent at the time of sampling (table 2). These minor bridge runoff contributions suggested a strong potential for dilution of any storm runoff entering the stream from the bridge. The range in sampled streamflow conditions provided the opportunity to compare the impact of bridge-deck runoff during periods of low streamflow, when less dilution of the bridge runoff in the receiving water would occur, to periods of high streamflow, when increased dilution would occur. In fact, storm 2 on July 10, 2014, probably represented the greatest potential for impact because Lynches River had a long period since last rainfall (17 days), extremely low-flow conditions $\left(216 \mathrm{ft}^{3} / \mathrm{s}\right)$, and relatively high intensity (0.68 in/ $\mathrm{hr})$ and rainfall ( 0.18 in.) amounts, producing the maximum percentage of bridge-deck runoff rate to streamflow at this bridge site $(0.19$ percent; table 2$)$. Those conditions represented the lowest dilution capacity in the river as well as greater opportunity for accumulation of contaminants on the deck prior to rainfall and subsequent wash-off during rainfall.

At the Lynches bridge site, a one-time sampling of the accumulated sediment on the deck of the bridge near the storm drainage systems (downspouts and vertical openings) was conducted in November 2013 before the start of water sampling (table 3). About midway through the water-sampling period, streambed sediment was sampled once (August 2014) and Hester-Dendy multiplate artificial substrates were deployed (July to August 2014) at transects upstream and downstream from the Lynches bridge site.

Specific conductance measurements made at the Lynches bridge site during routine and storm sampling events ranged from 53 to 93 microsiemens per centimeter $(\mu \mathrm{S} / \mathrm{cm})$ at 25 degrees Celsius during the sampling period, indicative of waters with low ionic strength (appendix table 3.1; fig. $9 A$ ). Even during storms, turbidity remained well below the SCDHEC criterion of 50 nephelometric turbidity units (NTU), ranging from 4.1 to 17.9 formazin nephelometric units
(FNU) during storm and routine samplings (fig. 9B; appendix 3.1; Romanok and others, 2020). Formazin nephelometric units can be considered similar to NTU in that both measure scattered light at 90 degrees from the incident light beam, but the FNU is measured with an infrared light source whereas the NTU is measured with a white light source (Anderson, 2005). At the Lynches bridge site, $\mathrm{pH}$ ranged from 5.9 to 7.0 standard units (SU) and had a median of about 6.5 SU for all (routine and storm) samplings (fig. $9 C$; appendix table 3.1; Romanok and others, 2020). DO concentrations ranged from 6.1 to $11.7 \mathrm{mg} / \mathrm{L}$ during the study period and were above the SCDHEC criterion of minimum DO above $4 \mathrm{mg} / \mathrm{L}$ (fig. 9D; table 4). Although one $\mathrm{pH}$ value fell below the SCHDEC range of 6 to 9, low $\mathrm{pH}$ and ionic strength waters are common in Coastal Plain streams in South Carolina and were considered a natural condition (South Carolina Department of Health and Environmental Control, 2014c).

Permutation one-factor tests were run to compare SC, $\mathrm{pH}$, DO, and turbidity measurements among the three sample groups: routine, storm_US, and storm_DS. Permutationderived $F$ statistics (signal-to-noise ratio) were low and associated $p$-values were greater than 0.05 , indicating that the within-group variation was greater than the among-group variation for these water-quality data (table 9). Based on these test results, the mean of $\mathrm{SC}, \mathrm{pH}, \mathrm{DO}$, and turbidity measurements did not vary among the three groups, including the storm_DS sample group that received the bridge-deck runoff. These results indicated that bridge-deck runoff during storms at the Lynches bridge site did not significantly alter the water quality in Lynches River at the downstream and upstream transects from the ambient conditions during nonstorm (routine) conditions at the upstream (no bridge influence) transect (figs. 9A-D). The Wilcoxon one-side signed rank test also indicated that physical properties of $\mathrm{SC}, \mathrm{pH}$, DO, and turbidity did not significantly increase downstream from the bridge during storms when compared to the upstream transect ( $p$-value $<0.05$; table 10$)$.

Excess amounts of nutrients and suspended sediment can have deleterious effects on water-quality and biological conditions of the surface-water system. Although the SCDHEC has not yet established numeric criteria for nutrients or suspended sediment in rivers and streams, concentrations of these constituents were assessed to determine if bridge-deck runoff caused measurable enrichment. At the Lynches bridge site, TN (particulate plus dissolved) concentrations ranged from 0.59 to $1.08 \mathrm{mg} / \mathrm{L}$ in all samples (appendix table 3.1; Romanok and others, 2020). Median TN concentrations of $0.83,0.80$, and $0.81 \mathrm{mg} / \mathrm{L}$ in routine, storm_US, and storm_DS samples, respectively, demonstrated a consistent central tendency in nitrogen levels in Lynches River for storm and nonstorm conditions (appendix table 3.1; fig. 10B; Romanok and others, 2020). TN concentrations consisted of species of $\mathrm{NO}_{2}+\mathrm{NO}_{3}$ and TKN concentrations. Median TKN concentrations were $0.42,0.42$, and $0.37 \mathrm{mg} / \mathrm{L}$ in samples from routine, storm_US, and storm_DS samples, respectively (appendix table 3.1; fig. 10C; Romanok and others, 2020), 
whereas median $\mathrm{NO}_{2}+\mathrm{NO}_{3}$ concentrations were slightly lower at $0.34,0.39$, and $0.38 \mathrm{mg} / \mathrm{L}$, respectively (fig. $10 \mathrm{~A}$ ).

Correspondingly, all nitrogen species exhibited similar concentration ranges among the routine (nonstorm), storm_US, and storm_DS sample conditions.

TP and SSC commonly behave similarly in surfacewater systems, especially when TP consists predominantly of sediment-bound (particulate) forms of phosphorus. Conceptually, if TP was predominantly sediment-bound on the bridge deck, then stormwater could mobilize bridge-deck sediment and discharge it into the receiving water during runoff, causing both TP and SSC to increase in the receiving water. At the Lynches bridge site, median TP concentrations were $0.063,0.054$, and $0.054 \mathrm{mg} / \mathrm{L}$, and median SSC concentrations were 6,6 , and $7 \mathrm{mg} / \mathrm{L}$ in samples from routine, storm_US, and storm_DS samples, respectively (appendix table 3.1; figs. $10 D, 10 E$; Romanok and others, 2020). Overall, there was no observable change in range of nutrients or SSCs in storm_DS samples compared to the other sample groups.

Permutation one-factor tests were run on the nutrient and SSC data to compare concentrations among routine, storm_US, and storm_DS samples to determine if statistical differences were present. Resulting permutation-derived $F$ statistics were low, and $p$-values were greater than 0.05 , indicating that the within-group variation was greater than the among-group variation for these water-quality data (table 9). These results indicated that bridge-deck runoff during storms at the Lynches bridge site did not significantly alter the nutrients and SSCs in the Lynches River at the downstream and upstream transects from the ambient conditions during nonstorm (routine) conditions at the upstream (no bridge influence) transect (figs. 10A-E). The Wilcoxon one-side signed rank test also indicated that nutrients and SSCs did not significantly increase downstream from the bridge during storms when compared to the upstream transect ( $p$-value $<0.05$; table 10 ).

Except for cadmium, trace metals were detected frequently in stream water during routine and storm samplings. Based on a hardness range of 13.7 to $18.1 \mathrm{mg} / \mathrm{L}$ at the Lynches bridge site, total recoverable chromium, copper, zinc, arsenic, mercury, and selenium concentrations were consistently below the SCDHEC $\mathrm{CMC}$ and $\mathrm{CCC}$ for aquatic life established for Lynches River freshwater use (table 4; appendix table 3.1; fig. 11; Romanok and others, 2020). An exception was a one-time total lead concentration of 0.57 microgram per liter $(\mu \mathrm{g} / \mathrm{L})$ that exceeded the CCC of $0.54 \mu \mathrm{g} / \mathrm{L}$ (but not the CMC of $14 \mu \mathrm{g} / \mathrm{L}$ ), but that value was observed in a routine sample on August 12, 2014, and was not related to bridge-deck runoff. However, median lead concentrations of $0.37,0.36$, and $0.33 \mathrm{mg} / \mathrm{L}$ in routine, storm_US, and storm_DS samples were about 40 percent lower than the $\mathrm{CCC}$, indicating that aquatic life were not exposed continuously to elevated lead concentrations.

Permutation one-factor tests had $p$-values greater than 0.05 for all total and dissolved trace metals, indicating that the within-group variation was greater than the among-group variation for these water-quality data (table 9). These results indicated that bridge-deck runoff during storms at the Lynches bridge site did not significantly alter trace-metal concentrations in Lynches River at the downstream and upstream transects from the ambient conditions during nonstorm (routine) conditions at the upstream (no bridge influence) transect (figs. $11 A-F$ ). Additionally, because all concentrations during storms were below the SCDHEC freshwater aquatic-life criteria, trace metals in stormwater runoff from the bridges was not expected to impair aquatic-life conditions in the Lynches River.

Dissolved and total trace-metal concentrations in stream water at the Lynches bridge site were tested using Wilcoxon signed rank tests at the paired downstream and upstream transects to determine whether the transect downstream from the bridge consistently had greater concentrations in its stream water than the transect upstream from the bridge for all storms. Because of the lack of detections, cadmium concentrations were not tested. Tests indicated that trace-metal concentrations did not significantly increase downstream from the bridge during storms when compared to the upstream transect ( $p$-value $<0.05$; table 10$)$.

E. coli is the fecal indicator bacteria used by the SCDHEC to assess recreational use attainment for surface-water systems, with a daily maximum criterion of $349 \mathrm{MPN} / 100 \mathrm{~mL}$ (table 4). During the period of study, E. coli concentrations remained well below the SCDHEC criterion, with the maximum E. coli concentration of $137 \mathrm{MPN} / 100 \mathrm{~mL}$ occurring during storm sampling (appendix table 3.1; Romanok and others, 2020). Composite samples (only) collected during routine, nonstorm conditions at upstream and downstream transects at the Lynches bridge site were compared to composite samples collected during storms at the same locations (fig. 12). Routine composite samples had $E$. coli concentrations that ranged from 28 to $75 \mathrm{MPN} / 100 \mathrm{~mL}$, whereas storm samples ranged from 58 to $133 \mathrm{MPN} / 100 \mathrm{~mL}$ (upstream transect) and 55 to $137 \mathrm{MPN} / 100 \mathrm{~mL}$ (downstream transect). Median E. coli concentrations were $57 \mathrm{MPN} / 100 \mathrm{~mL}$ in routine samples but were almost doubled to 105 and $96 \mathrm{MPN} / 100 \mathrm{~mL}$ in upstream and downstream storm samples, respectively (appendix table 3.1; Romanok and others, 2020). However, permutation one-factor tests indicated that there were no statistically significant differences in E. coli concentrations between nonstorm and storm conditions (table 9; fig. 12; $F=1.726$; $p$-value $=0.215$ ). E. coli concentrations in stream water also were tested to determine whether the transect downstream from the bridge consistently had greater concentrations than the transect upstream from the bridge for all storms. Wilcoxon one-side signed rank test indicated that $E$. coli concentrations did not significant increase downstream from the bridge during storms when compared to the upstream transect $(Z=0.405, p$-value $=0.407$; table 10$)$.

Of the 17 analyzed PAH compounds in the 23 stream water samples (the sample bottle for PAHs for the August 12,2014 , routine sample was broken during shipment to the NWQL), only 3 PAHs were detected, each just once, so statistical testing on individual compounds was not performed. Detected PAHs concentrations were reported as estimated (E; less than their LRL; Romanok and others, 2020). Naphthalene 
was detected once in the routine sample collected on July 8, 2014, and had a concentration below the LRL of $0.22 \mu \mathrm{g} / \mathrm{L}$ (E $0.020 \mu \mathrm{g} / \mathrm{L}$ ). Two PAH compounds were detected in the storm DS samples collected February 22, 2015: pyrene at E $0.004 \mu \mathrm{g} / \mathrm{L}(\mathrm{LRL}=0.36 \mu \mathrm{g} / \mathrm{L})$ and benzo[b]fluoranthene at E $0.005 \mu \mathrm{g} / \mathrm{L}(\mathrm{LRL}=0.30 \mu \mathrm{g} / \mathrm{L}$; Romanok and others, 2020).

The sum of all 17 PAH compound concentrations $\left(\Sigma \mathrm{PAH}_{17}\right)$ and the total number of PAH detections $\left(\mathrm{PAH}_{\text {detect }}\right)$ in water for each sampling at the Lynches site were computed as metrics to represent PAH occurrence. The two metrics were compared among routine, storm_US, and storm_DS sample groups. Stream water at the Lynches site (storm_DS samples) that received bridge-deck runoff had detections of PAH compounds at low levels in only one of five storms, whereas storm_US samples had no detections. Routine samples had detectable PAH concentrations in 1 of 13 samples at the same low level; therefore, no overall change in PAH concentration during storms seemed to be evident at this site.

During routine sampling at the upstream transect when low-flow conditions were present, an increase in specific conductance was observed in the field measurement at the EWI increment closest to the left edge of water. A low-volume surface-water discharge (tributary) was observed on the left bank about $30 \mathrm{ft}$ upstream from the upstream transect of the Lynches bridge site. On October 9, 2014, a one-time grab sample in Lynches River near this discharge was collected, analyzed, and compared to the routine Lynches River sample collected on the same day (Romanok and others, 2020). The discharge had extremely low DO $(2.6 \mathrm{mg} / \mathrm{L})$ and extremely high SC $(1,253 \mu \mathrm{S} / \mathrm{cm})$ compared to the routine sample ( $7.8 \mathrm{mg} / \mathrm{L}$ and $59 \mu \mathrm{S} / \mathrm{cm}$, respectively). The increased SC seemed to be related to high concentrations of sodium and chloride. Concentrations of $E$. coli concentrations $(770,100 \mathrm{MPN} / 100 \mathrm{~mL})$, total zinc $(15 \mu \mathrm{g} / \mathrm{L})$, total copper $(10.1 \mu \mathrm{g} / \mathrm{L})$, ammonia $(0.990 \mathrm{mg} / \mathrm{L})$, and total phosphorus $(1.60 \mathrm{mg} / \mathrm{L})$ in the discharge were well above the concentrations observed in routine and storm samples collected at the Lynches bridge site (figs. 10-12).

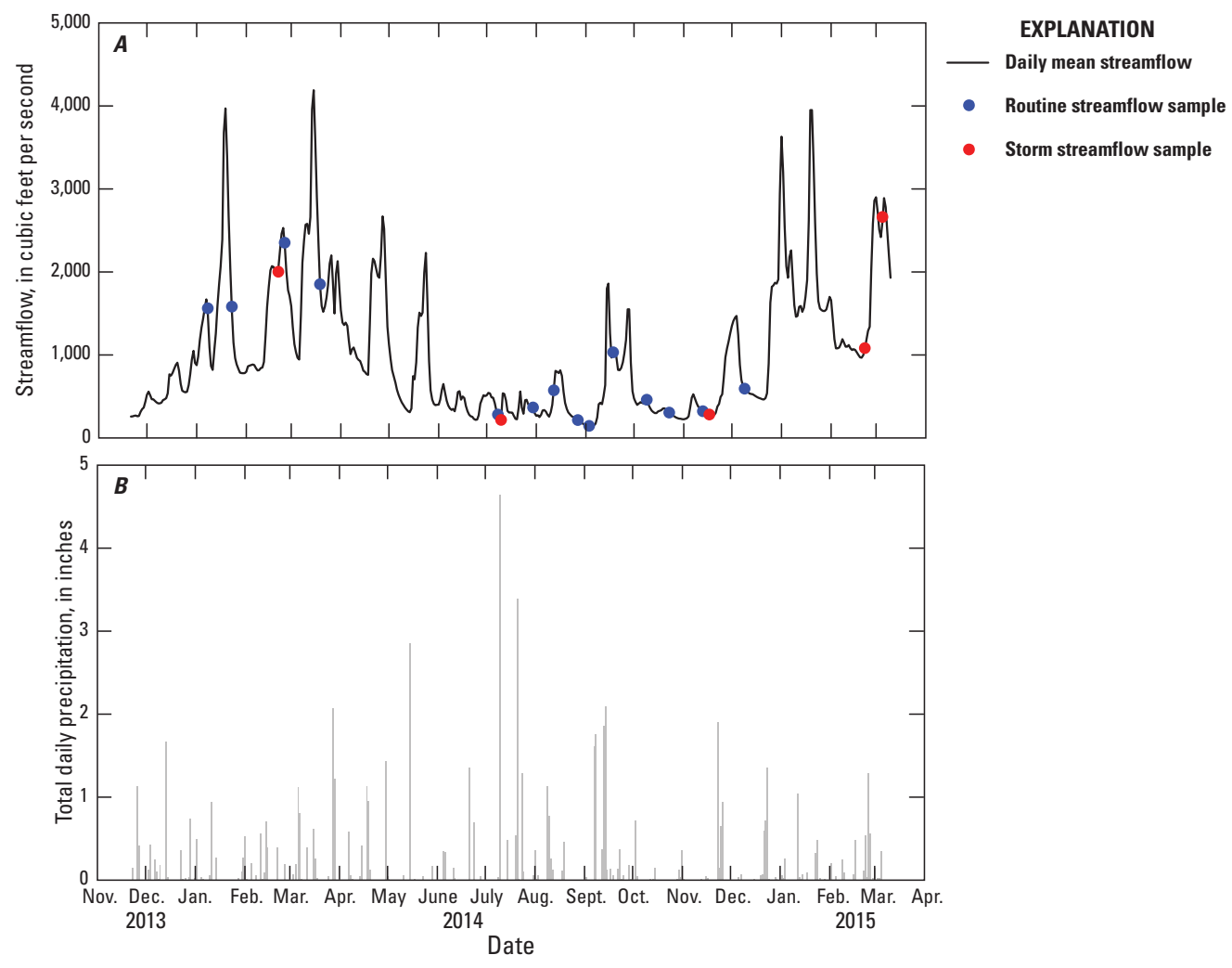

Figure 8. Graphs showing a time series of, $A$, daily mean streamflow and instantaneous streamflow during sampling and, $B$, total daily precipitation at Lynches River at Effingham, South Carolina (U.S. Geological Survey station 02132000), November 2013 to March 2015. 

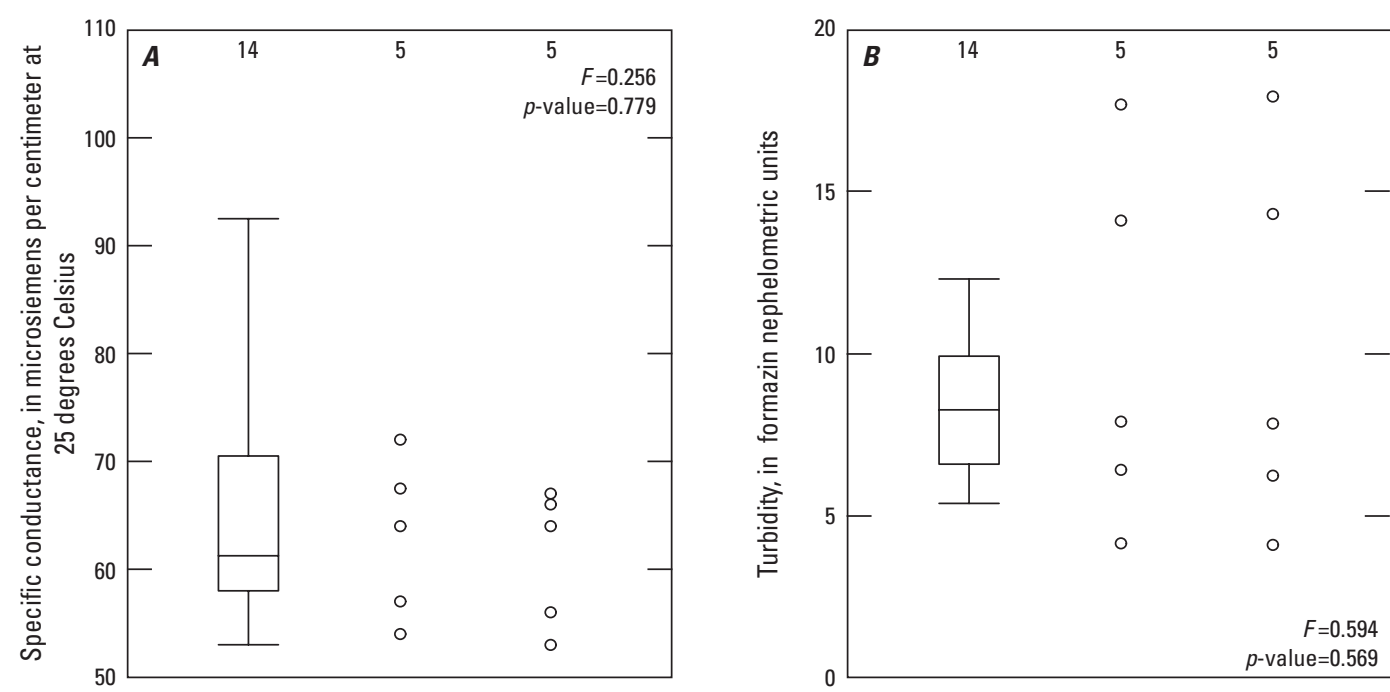

EXPLANATION

14 Number of samples

Maximum

$T^{75 \text { th percentile }}$

Median

25th percentile

I Minimum

Note: Small circles are shown instead of a boxplot if the

number of samples is five or less F, Fstatistic

$p$-value, probability value

US, upstream

DS, downstream
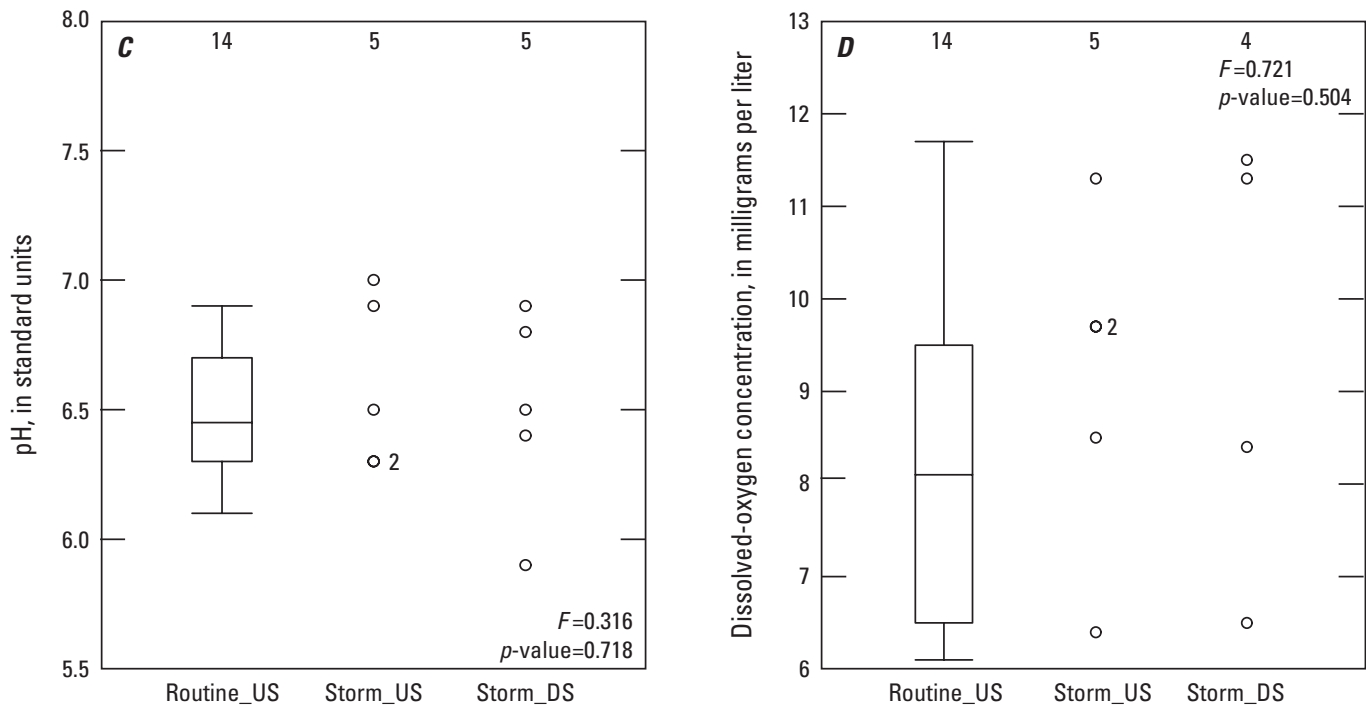

Condition and location

Figure 9. Boxplots showing field properties in stream water at Lynches River at Effingham, South Carolina, measured at upstream and downstream locations during routine and storm conditions, January 2014 to March 2015. A, specific conductance. $B$, turbidity. $C$, pH. $D$, dissolved-oxygen concentration. 

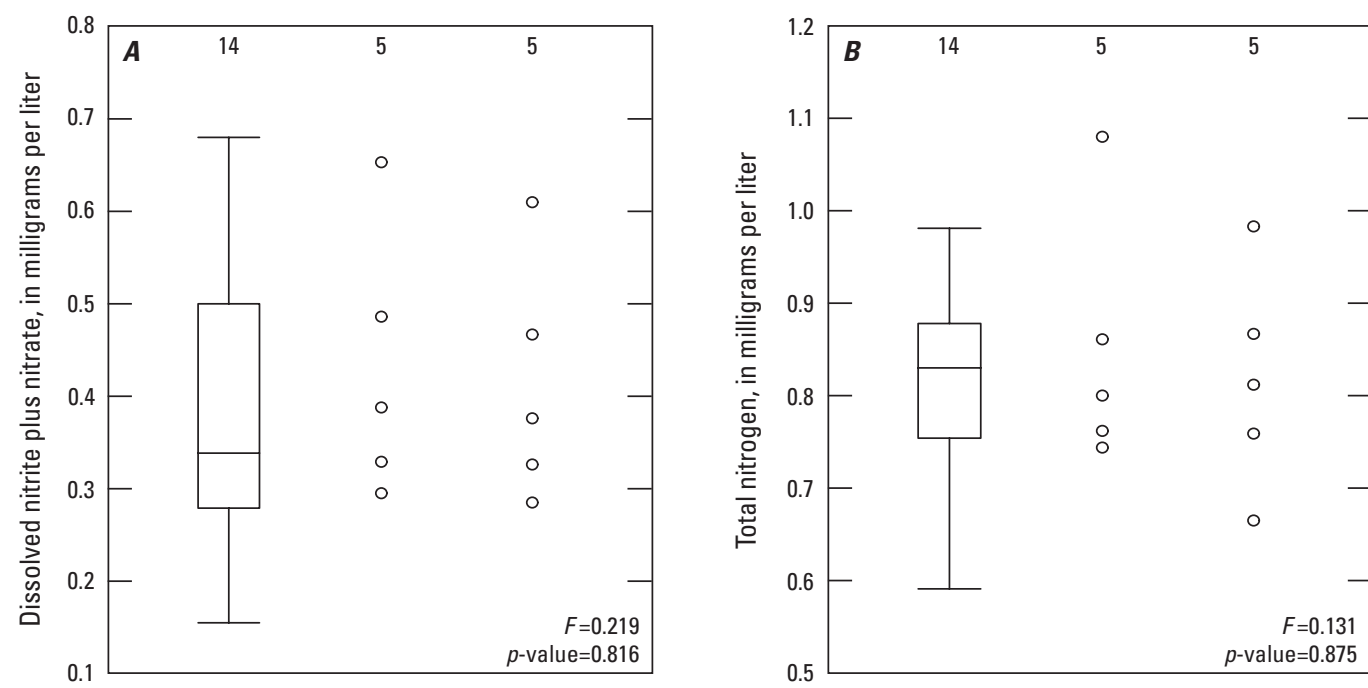

EXPLANATION

14 Number of samples

Maximum

75th percentile

Median

25th percentile

Minimum

- - Laboratory reporting limit

Note: Small circles are shown instead of a boxplot if the number of samples is five or less.

The number beside the circle means that there is more than one sample at that location. $F, F$ statistic

$p$-value, probability value

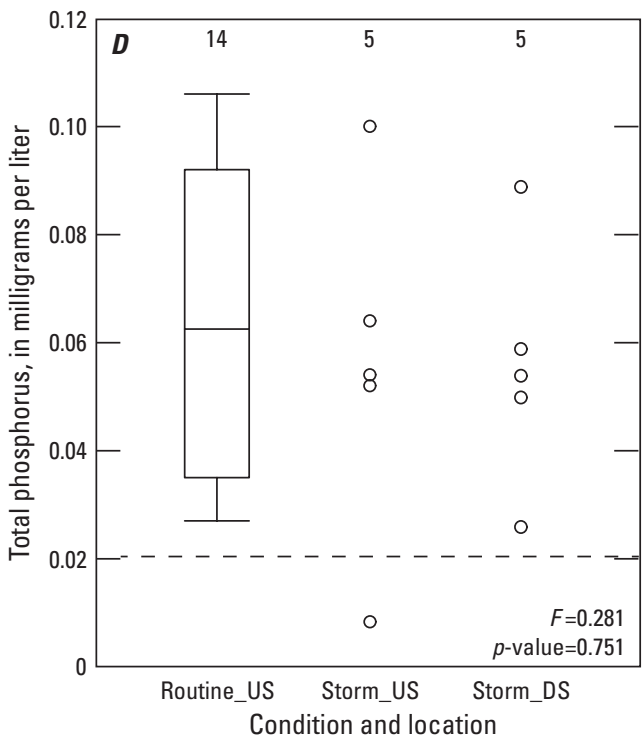

US, upstream

DS, downstream
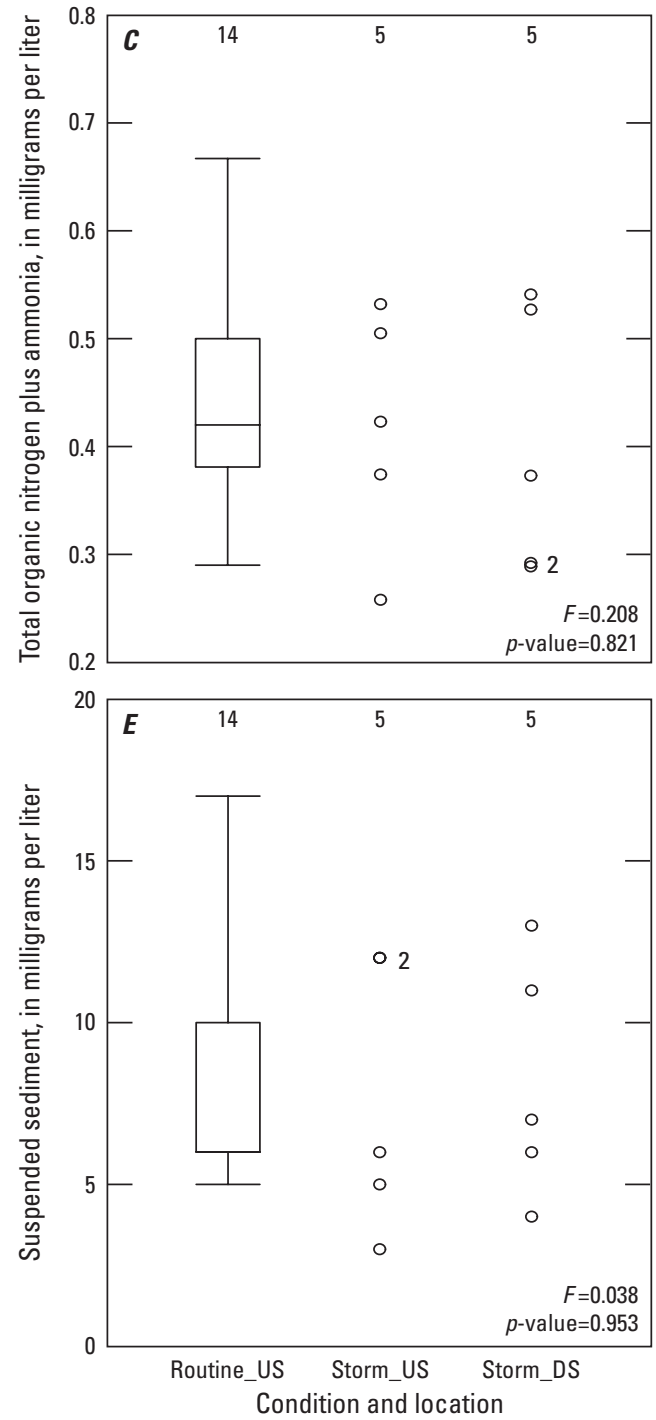

Condition and location

Figure 10. Boxplots showing nutrient and suspended-sediment concentrations in stream water at Lynches River at Effingham, South Carolina, measured at upstream and downstream transects during routine and storm conditions, January 2014 to March 2015. $A$, dissolved nitrite plus nitrate. $B$, total nitrogen. $C$, total organic nitrogen plus ammonia. $D$, total phosphorus. $E$, suspended sediment. 

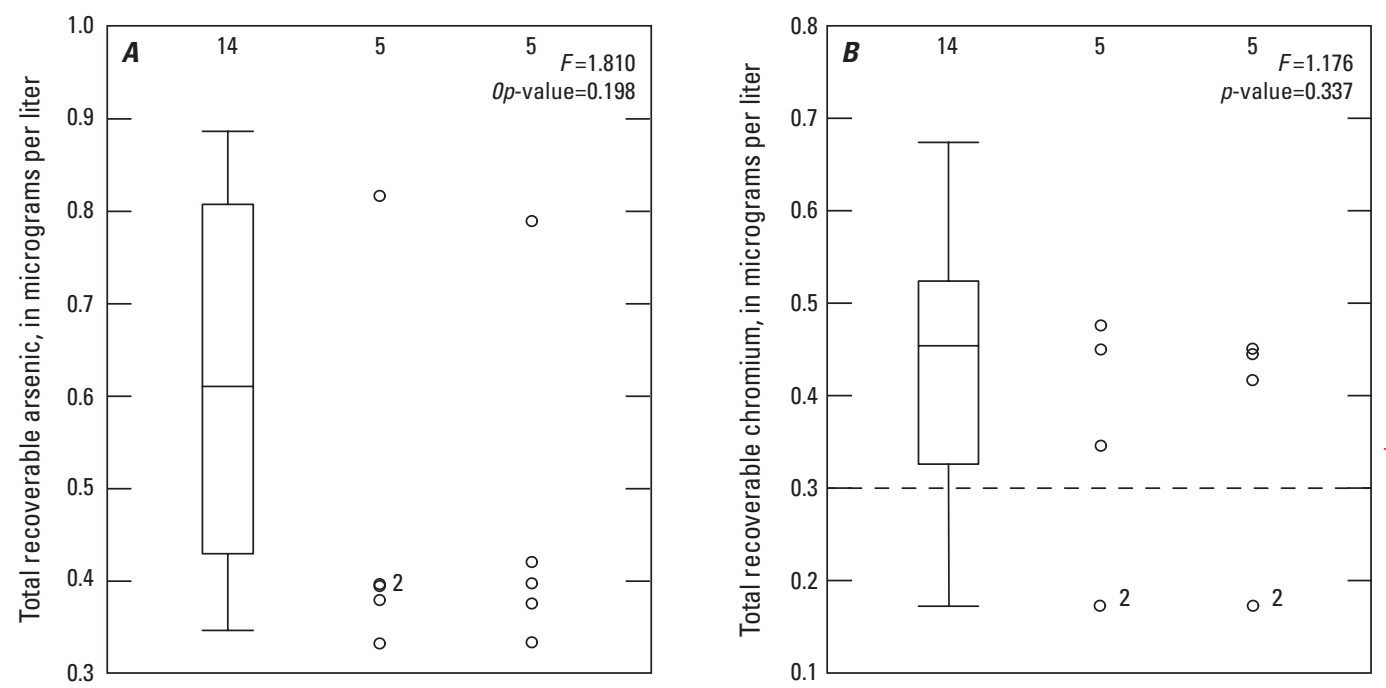

EXPLANATION

14 Number of samples

Maximum

75th percentile

Median

25th percentile

Minimum

- - Laboratory reporting limit

South Carolina Department of Health and Environmental Control criterion continuous concentration

Note: Small circles are shown instead of a boxplot if the number of samples is five or less. The number beside the circle means that there is more than
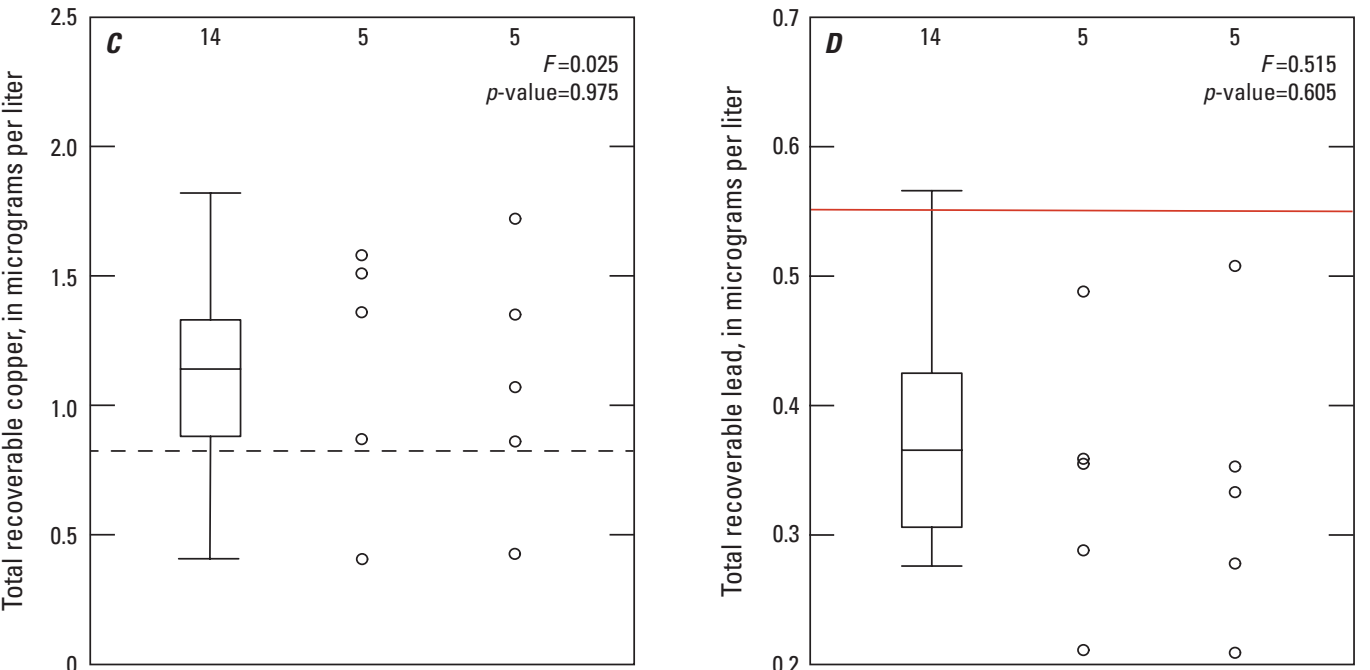
one sample at that location.

$F$, Fstatistic

$p$-value, probability value

US, upstream

DS, downstream
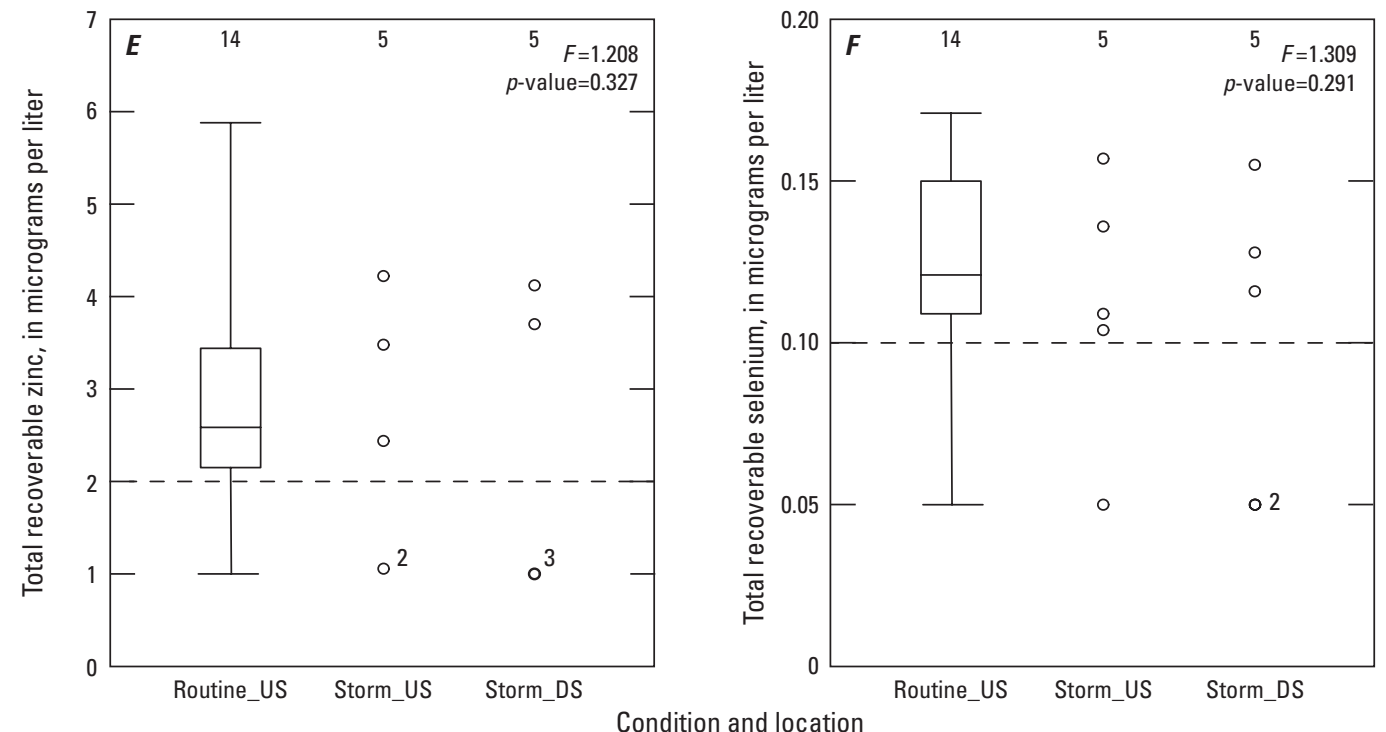

Figure 11. Boxplots showing total recoverable trace-metal concentrations in stream water at Lynches River at Effingham, South Carolina, measured at upstream and downstream transects during routine and storm conditions, January 2014 to March 2015. $A$, arsenic. $B$, chromium. $C$, copper. $D$, lead. $E$, zinc. $F$, selenium. 


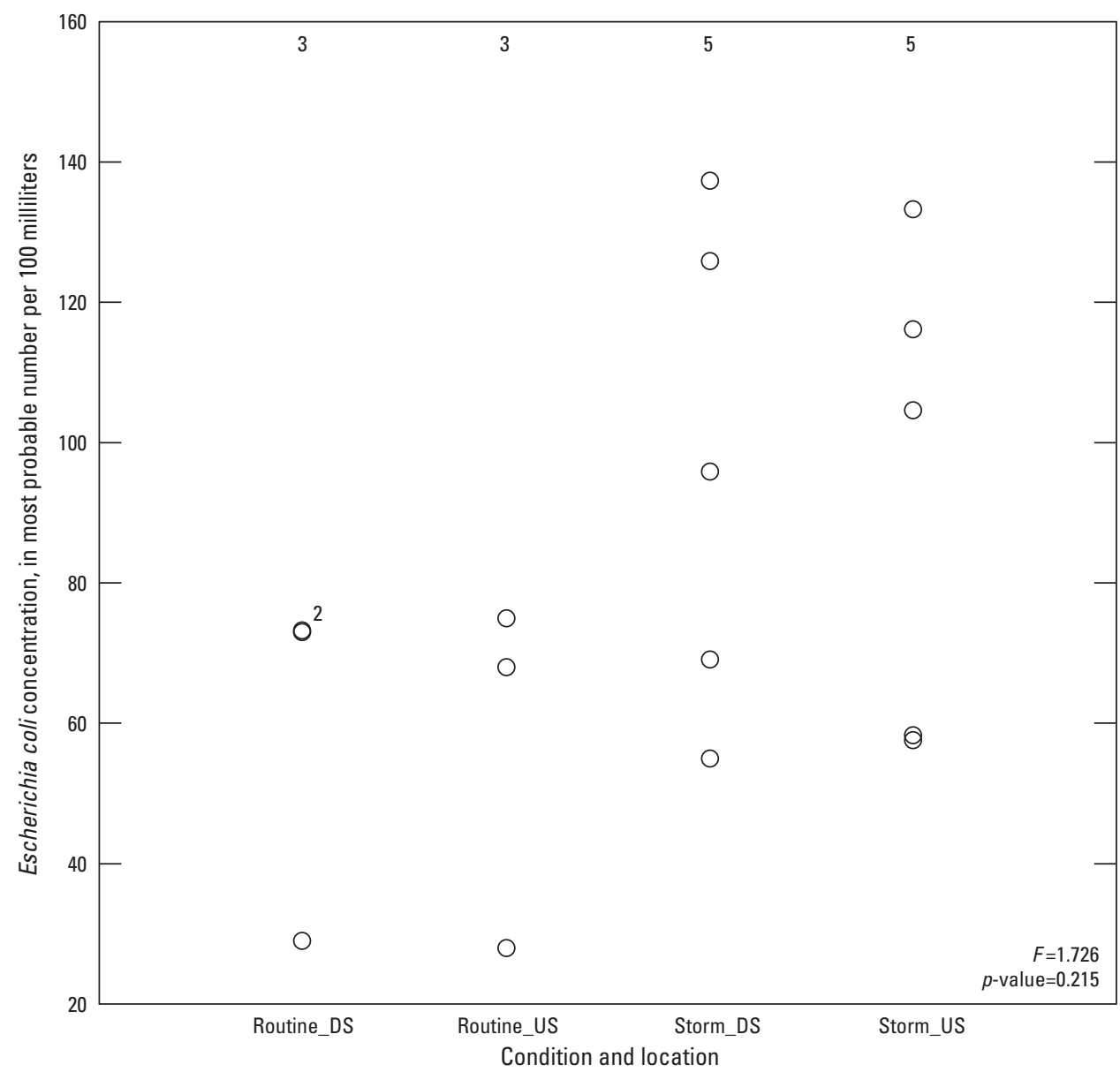

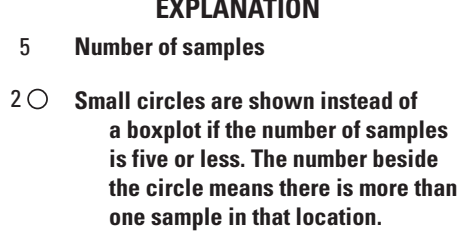

Note: F, Fstatistic $p$-value, probability value US, upstream

DS, downstream

Figure 12. Boxplot showing Escherichia coli concentrations in stream water at Lynches River at Effingham, South Carolina (U.S. Geological Survey station 02132000), measured at upstream and downstream transects during routine and storm conditions, January 2013 to March 2015.

\section{North Fork Edisto River}

In total, 14 routine (nonstorm) and 12 storm samples were collected from North Fork Edisto River at the NFEdisto bridge site from January 2014 to March 2015 (table 3; appendix table 3.2; Romanok and others, 2020). Streamflow ranged from 386 to $870 \mathrm{ft}^{3} / \mathrm{s}$ at the time of storm sampling and from 180 to $767 \mathrm{ft}^{3} / \mathrm{s}$ at the time of routine sampling (table 2; appendix table 3.2; fig. 13A; Romanok and others, 2020). The range in sampled streamflows compared well with the mid-range of daily flow for the period of record at the NFEdisto site, falling above the 25th percentile of $442 \mathrm{ft}^{3} / \mathrm{s}$ and near the 75th percentile of $856 \mathrm{ft}^{3} / \mathrm{s}$ (table 1). Precipitation at the NFEdisto bridge site was only in the form of rainfall during the period of study. Rainfall amounts of the sampled storms ranged from 0.02 to 0.13 in. with intensities that ranged from 0.08 to $0.24 \mathrm{in} / \mathrm{hr}$; table 2; fig. $13 B$ ). Antecedent conditions ranged from 1 to 10 days since last rainfall. The mean potential bridge-deck runoff rate (bridge discharge) for each storm was estimated to range from 0.028 to $0.087 \mathrm{ft}^{3} / \mathrm{s}$, representing ratios of bridge-deck runoff rates to streamflow of 0.006 to 0.015 percent at the time of sampling (table 2).
These minor bridge-deck runoff contributions suggested a strong potential for dilution of any storm runoff entering the stream from the bridge. Although not as remarkable as storm 2 at Lynches site, storm 3 on September 29, 2014, probably represented the greatest potential of impact because it had been 7 days since last rainfall, the NFEdisto bridge site had relatively low-flow conditions $\left(386 \mathrm{ft}^{3} / \mathrm{s}\right)$, and the storm had intermediate intensity $(0.12 \mathrm{in} / \mathrm{hr})$, duration $(0.52 \mathrm{hr})$, and rainfall (0.06 in.; table 2). Of the storms sampled at this site, those conditions provided the least dilution capacity of the river while a good opportunity for accumulation of contaminants on the deck before rainfall and potential of wash-off of those contaminants during rainfall.

At the NFEdisto bridge site, a one-time sampling of the accumulated sediment on the bridge deck near the storm drainage systems (downspouts and vertical openings) was conducted in November 2013 before the start of water sampling (table 3). About midway through the water-sampling period, streambed sediment was sampled once (August 2014) and Hester-Dendy artificial substrates were deployed (July to August 2014) at transects downstream and upstream from the NFEdisto bridge site. 
Specific conductance measurements made at the NFEdisto bridge site ranged from 29 to $46 \mu \mathrm{S} / \mathrm{cm}$ during the sampling period, indicative of waters with low ionic strength (appendix table 3.2; fig. 14A; Romanok and others, 2020). Turbidity levels remained well below the SCDHEC criterion of $50 \mathrm{NTU}$, ranging from 2.0 to $8.3 \mathrm{FNU}$ during storm and routine samplings (fig. 14B). At the NFEdisto bridge site, $\mathrm{pH}$ ranged from 5.7 to $6.4 \mathrm{SU}$ and had medians of 6.0 to $6.1 \mathrm{SU}$ for routine and storm samplings (fig. $14 C$; appendix table 3.2; Romanok and others, 2020). However, $\mathrm{pH}$ was observed to remain above 6 in stream water downstream from the bridge during storms at the NFEdisto bridge site. DO concentrations ranged from 5.5 to $13.5 \mathrm{mg} / \mathrm{L}$ during the study period and were above the SCDHEC criterion of minimum DO above $4 \mathrm{mg} / \mathrm{L}$ (fig. 14D; table 4). Although median $\mathrm{pH}$ was within the SCHDEC range of 6 to 9, some $\mathrm{pH}$ values fell below 6 at the upstream transect only. However, low $\mathrm{pH}$ and ionic strength waters are common in Coastal Plain streams in South Carolina and were considered a natural condition (South Carolina Department of Health and Environmental Control, 2012a).

Permutation one-factor tests were run to compare $\mathrm{SC}, \mathrm{pH}, \mathrm{DO}$, and turbidity measurements among the three locations. Permutation-derived $F$ statistics were generally low and associated $p$-values were greater than 0.05 , indicating that the within-group variation was greater than the amonggroup variation for these water-quality data (table 9). These results indicated that bridge-deck runoff during storms at the NFEdisto bridge site did not significantly alter the physical properties of $\mathrm{SC}, \mathrm{pH}, \mathrm{DO}$, and turbidity in the North Fork Edisto River at the downstream and upstream transects from the ambient conditions during nonstorm (routine) conditions at the upstream (no bridge influence) transect (figs. 14A-D). The Wilcoxon one-side signed rank test also indicated that physical properties of SC, temperature, and turbidity did not significantly increase downstream from the bridge during storms when compared to the upstream transect ( $p$-value $>0.05$; table 10). A significant increase in $\mathrm{pH}$ downstream from the bridge was identified at the NFEdisto bridge site $(Z=1.977$; $p$-value $=0.029)$; however, the $\mathrm{pH}$ increase represented an improvement in water-quality conditions when compared to SCDHEC lower criterion of 6 .

At the NFEdisto bridge site, TN concentrations ranged from 0.47 to $0.74 \mathrm{mg} / \mathrm{L}$ in all samples (appendix table 3.2; Romanok and others, 2020). Median TN concentrations of $0.58,0.58$, and $0.57 \mathrm{mg} / \mathrm{L}$ in routine, storm_US, and storm_DS samples, respectively, demonstrated little variability in the central tendency of the data groups (appendix table 3.2; fig. 15B; Romanok and others, 2020). TN concentrations consisted of species of dissolved $\mathrm{NO}_{2}+\mathrm{NO}_{3}$ and TKN concentrations. Median TKN concentrations were 0.35 , 0.37 , and $0.35 \mathrm{mg} / \mathrm{L}$, in routine, storm_US, and storm_DS samples, respectively (appendix table 3.2 ; fig. $15 C$; Romanok and others, 2020), whereas median $\mathrm{NO}_{2}+\mathrm{NO}_{3}$ concentrations were slightly lower at $0.21,0.18$, and $0.17 \mathrm{mg} / \mathrm{L}$, respectively (fig. 15CA). Correspondingly, all nitrogen species exhibited similar concentration ranges among the three locations.
At the NFEdisto bridge site, median TP concentrations were $0.030,0.025$, and $0.025 \mathrm{mg} / \mathrm{L}$, and median SSCs were 5 , 4 , and $4 \mathrm{mg} / \mathrm{L}$ in routine, storm_US, and storm_DS samples, respectively (appendix table 3.2; fig. 15D, E; Romanok and others, 2020). Overall, there were no observable change in range of nutrient or SSCs in storm_DS samples compared to the other sample groups.

Permutation one-factor tests verified graphical observations on the nutrient and suspended sediment data by comparing concentrations among routine, storm_US, and storm_DS samples to determine if statistical differences were present. Resulting permutation-derived $F$ statistics and $p$-values greater than 0.05 for individual nutrient species and SSCs indicated that the within-group variation was greater than the among-group variation for these water-quality data (table 9). These results indicated that bridge-deck runoff during storms at the NFEdisto bridge site did not significantly alter the nutrient and SSCs in the North Fork Edisto River at the downstream and upstream transects from the ambient conditions during nonstorm (routine) conditions at the upstream (no bridge influence) transect (figs. 15A-E). The Wilcoxon one-side signed rank tests also indicated that nutrient and SSCs at the NFEdisto bridge site did not significantly increase downstream from the bridge during storms when compared to the upstream transect ( $p$-value $>0.05$; table 10).

Except for cadmium, trace metals were detected frequently in stream water during routine and storm samplings. Based on a hardness range of 7.4 to $12.2 \mathrm{mg} / \mathrm{L}$ at the NFEdisto bridge site, total recoverable lead, chromium, copper, zinc, arsenic, mercury, and selenium concentrations were consistently below the SCDHEC CMC and CCC for aquatic life established for North Fork Edisto River freshwater use (table 4; appendix table 3.2; figs. 16A-F; Romanok and others, 2020). Lead (total and filtered) was the most frequently detected metal, followed by arsenic, chromium, zinc, and mercury.

Permutation one-factor tests were run on the trace-metal data to compare concentrations among routine, storm_US, and storm_DS samples to determine if statistical differences were present. Resulting permutation-derived $F$ statistics that were relatively low, and $p$-values greater than 0.05 indicated that the within-group variation was greater than the among-group variation for these water-quality data (table 9). These results indicated that bridge-deck runoff during storms at the NFEdisto bridge site did not significantly alter the trace-metal concentrations in the North Fork Edisto River at the downstream and upstream transects from the ambient conditions during nonstorm (routine) conditions at the upstream (no bridge influence) transect (figs. 16A-F). The Wilcoxon one-side signed rank tests also indicated that trace-metal concentrations at the NFEdisto bridge site did not significantly increase downstream from the bridge during storms when compared to the upstream transect ( $p$-value $>0.05$; table 10). 
During the period of study, E. coli concentrations at the NFEdisto bridge site remained well below the SCDHEC criterion of $349 \mathrm{MPN} / 100 \mathrm{~mL}$, except for one storm on November 24, 2014, that had E. coli concentration of greater than 2,420 MPN/100 mL in samples from both upstream and downstream transects (table 4; appendix table 3.2; Romanok and others, 2020). Composite samples (only) collected during routine conditions at upstream and downstream transects at the NFEdisto bridge site were compared to composite samples collected during storms at the same transects (fig. 17). Routine composite samples (all locations) had E. coli concentrations that ranged from 73 to $153 \mathrm{MPN} / 100 \mathrm{~mL}$, whereas storm samples ranged from 74 to greater than 2,420 MPN/100 mL (upstream transect) and 79 to greater than 2,420 MPN/100 mL (downstream transect; appendix table 3.2; Romanok and others, 2020). Median E. coli concentrations were 116, 134, and $140 \mathrm{MPN} / 100 \mathrm{~mL}$ in routine, storm US, and storm DS samples, respectively (appendix table 3.2; Romanok and others, 2020). Although the range of concentrations for the storms was slightly elevated relative to the routine conditions, permutation one-factor tests indicated that the E. coli concentrations in the North Fork Edisto River at the downstream and upstream transects were not significantly altered from the ambient conditions during nonstorm (routine) conditions at the upstream (no bridge influence) transect (table 9; $F=0.522 ; p$-value $=0.499$ ). $E$. coli concentrations in stream water also were tested to determine whether the transect downstream from the bridge consistently had greater concentrations than the transect upstream from the bridge for all storms. Unlike the Lynches bridge site, results of the Wilcoxon test indicated that there was a consistent increase in $E$. coli concentrations downstream from the bridge at the NFEdisto bridge site during storms (table 10; $Z=2.108$; $p$-value $=0.031$ ). Although changes were minor, downstream E. coli concentrations increased from 0 to $39 \mathrm{MPN} / 100 \mathrm{~mL}$ ( 0 to 28 percent) during storms, with the greater change occurring during period of greater rainfall intensity. At the NFEdisto bridge site, Spearman $\rho$ correlation analysis was applied to measured $E$. coli concentrations at upstream and downstream transects and downstream changes (storm_DS minus storm_US concentration) in these concentrations. These E. coli values were correlated against turbidity and rainfall characteristics during the storms (rainfall intensity, rainfall amount, rainfall duration, and days since last rainfall; tables 3, 11; Romanok and others, 2020). Statistically significant and positive correlations $(\alpha=0.05)$ were identified between $E$. coli concentrations at upstream and downstream transects $(\rho=0.9999, p$-value $<0.001)$, indicating that $E$. coli concentrations tended to change similarly at both transects under similar storm conditions. Furthermore, storm conditions of greater rainfall amounts and duration were significantly correlated to greater $E$. coli concentrations at both upstream and downstream transects $(\rho=0.8120, p$-value $=0.0497)$ at the NFEdisto bridge site (table 11). However, greater rainfall duration and amounts were not correlated significantly with downstream increases (downstream concentration greater than upstream concentration) in E. coli concentrations during storms. Instead, greater rainfall intensity co-occurred with the downstream increases in $E$. coli concentrations during storms $(\rho=0.8940, p$-value $=0.0163)$. Although correlation is not causation, there is a potential that more intense rainfall transported greater amounts of $E$. coli from the bridge deck to the receiving water at this bridge site.

Of the 17 analyzed PAH compounds in the 26 stream water samples (routine and storm), only $8 \mathrm{PAHs}$ were detected and only during routine samplings, so statistical testing on individual compounds or metrics was not performed. PAHs detections were rare with most samples and compounds reported as less than their laboratory reporting levels (appendix table 3.2; Romanok and others, 2020). Eight of 17 PAHs were detected at least once but only during routine sampling: benzo[a]pyrene (1 detection), benzo[ $b]$ fluoranthene ( 2 detections), benzo[ghi]perylene ( 1 detection), chrysene (1 detection), fluoranthene (4 detections), indeno[1,2,3-cd] pyrene (1 detection), phenanthrene (1 detection), and pyrene (2 detections). No PAHs were detected during storm sampling. Concentrations of the detected PAHs were below their LRLs by an order of magnitude. The routine sample on September 4, 2014, during low-flow conditions (184 ft $\left.\mathrm{ft}^{3} / \mathrm{s}\right)$ had all 8 PAHs detected at the NFEdisto bridge site with $\Sigma \mathrm{PAH}_{17}$ of $0.227 \mu \mathrm{g} / \mathrm{L}$. Based on the absence of any detections during any of the six storms, PAH contribution from the bridge deck to the stream during runoff was considered negligible for this study. 

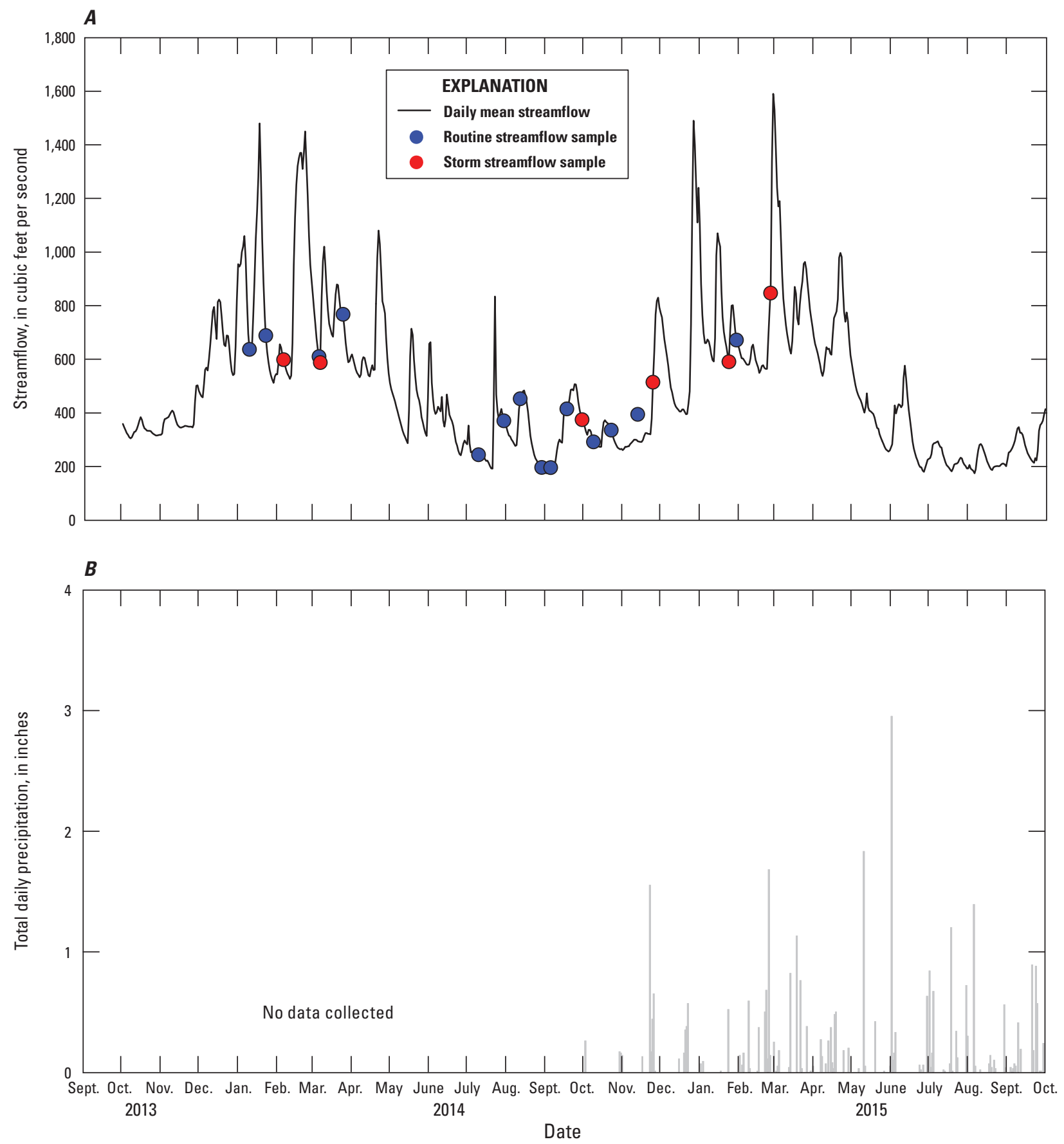

Figure 13. Graphs showing a time series of, $A$, daily mean streamflow and instantaneous streamflow during sampling and, $B$, total daily precipitation at North Fork Edisto River at Orangeburg, South Carolina (U.S. Geological Survey station 02173500), October 2013 to October 2015. 

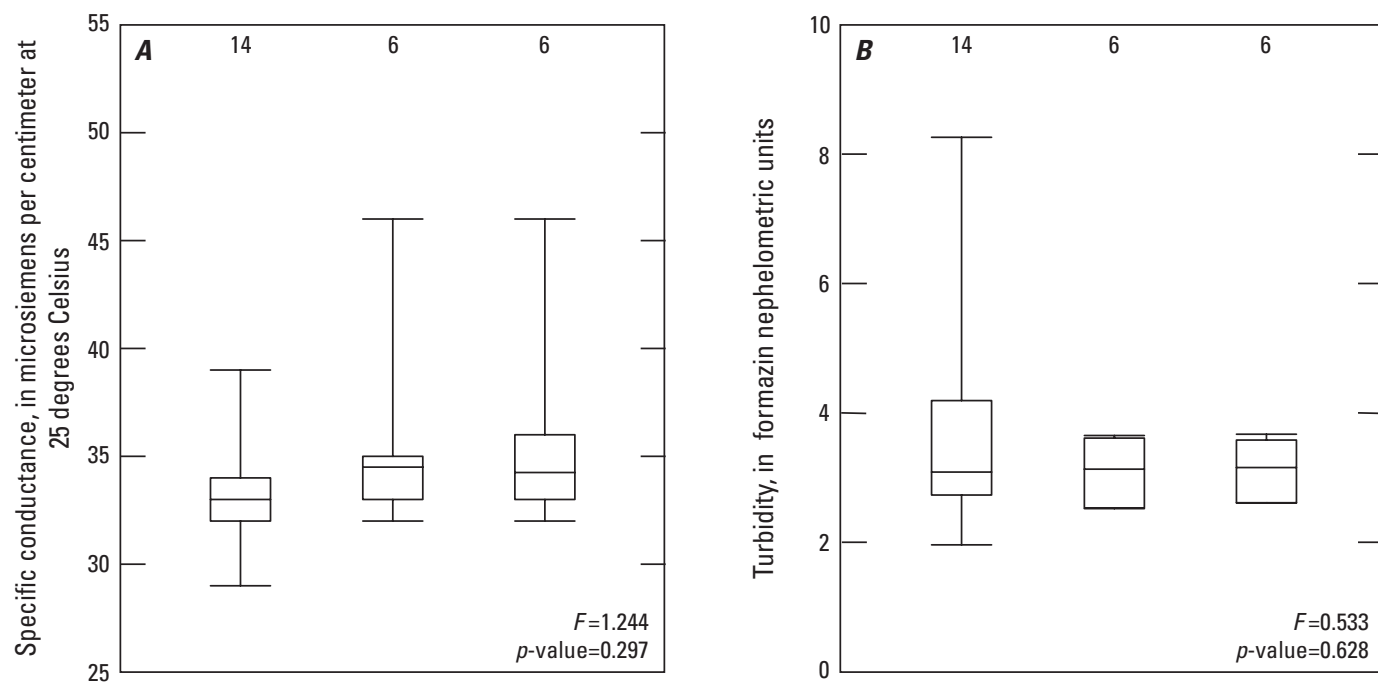

EXPLANATION

14 Number of samples

Maximum

75th percentile

Median

25th percentile

Minimum

Note: $F, F$ statistic

$p$-value, probability value

US, upstream

DS, downstream
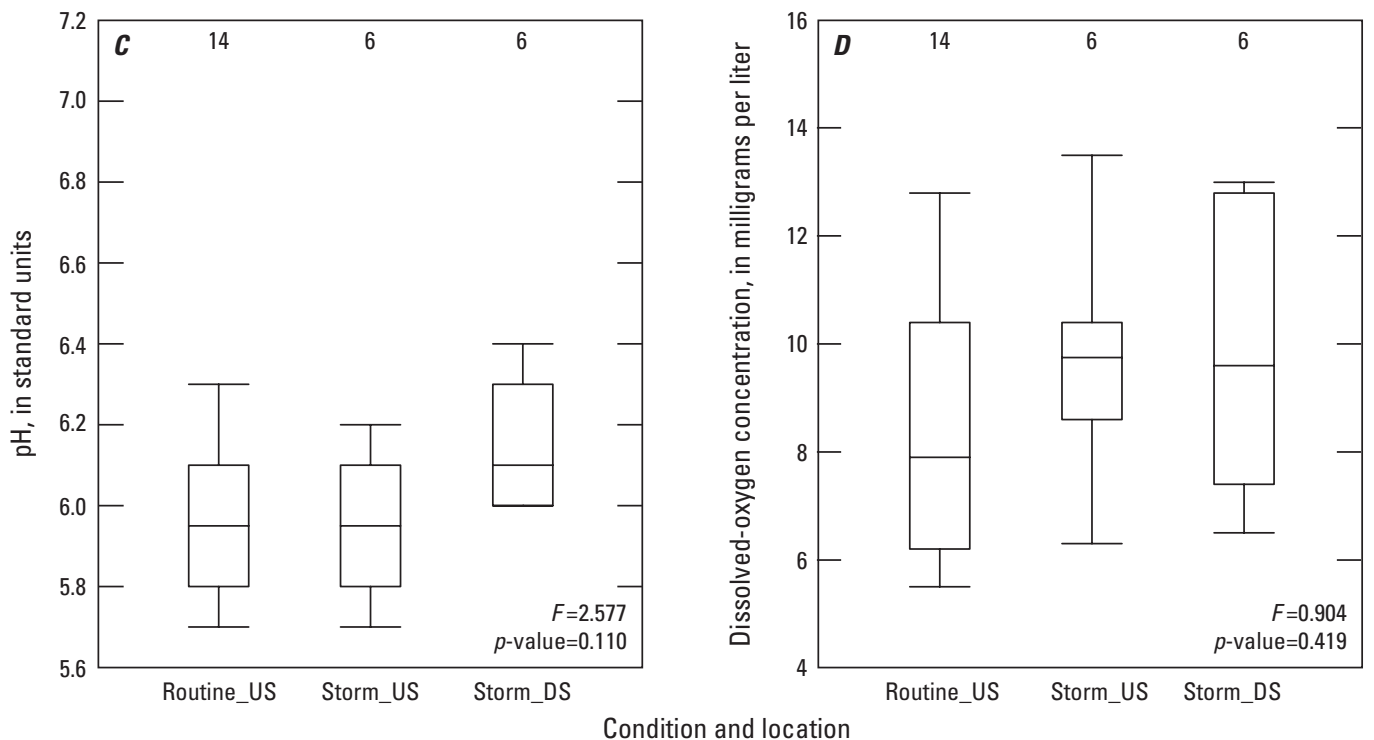

Figure 14. Boxplots showing field properties in stream water at North Fork Edisto River at Orangeburg, South Dakota (U.S. Geological Survey station 02173500), measured at upstream and downstream transects during routine and storm conditions, January 2014 to March 2015. A, specific conductance. B, turbidity. C, pH. D, dissolved oxygen. 

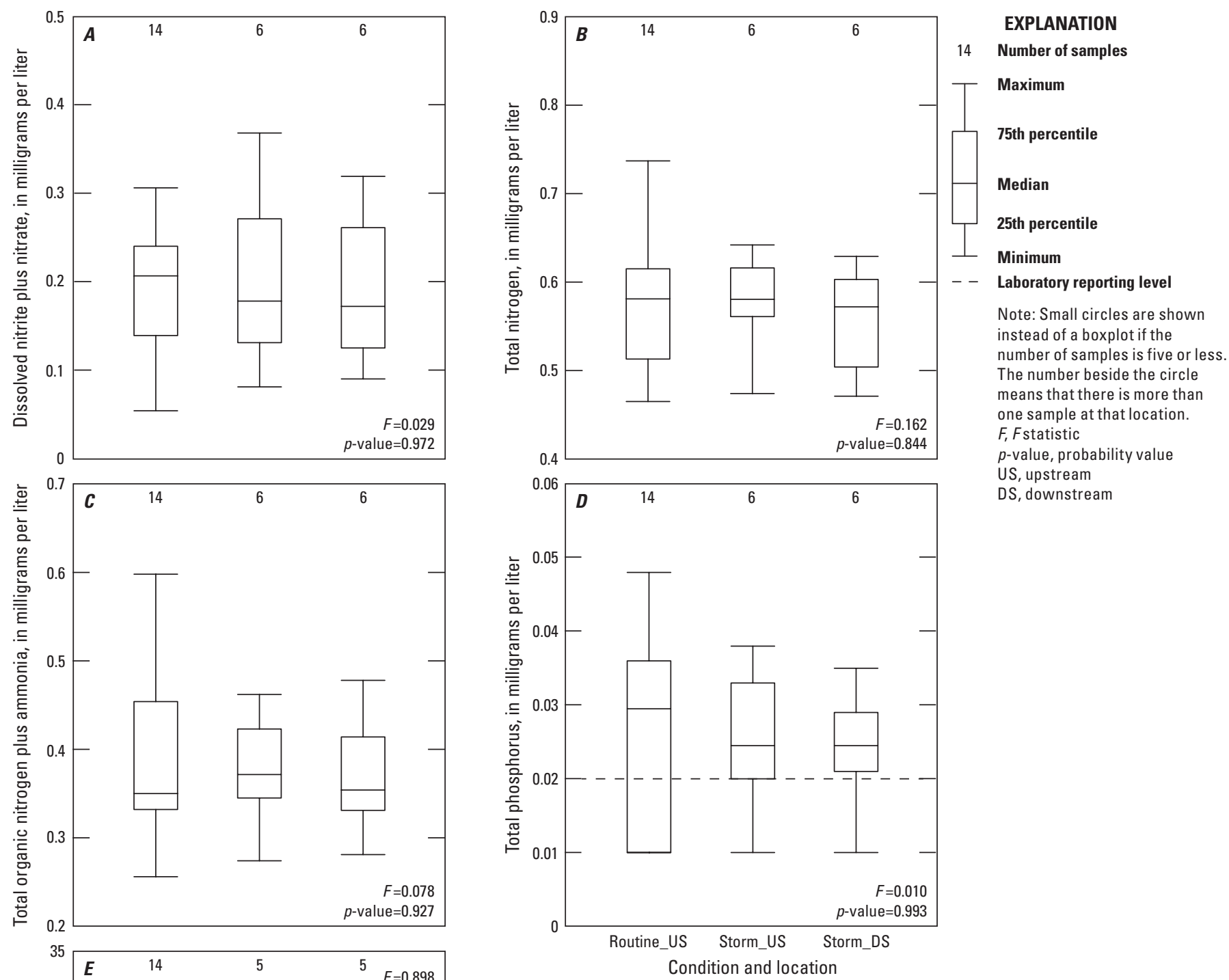

US, upstream

DS, downstream

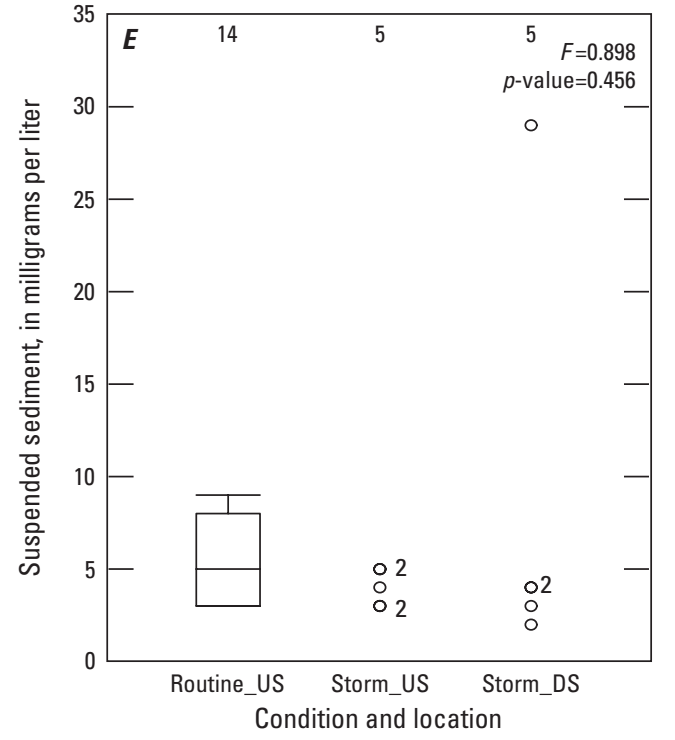

Figure 15. Boxplots showing nutrient and suspended-sediment concentrations in stream water at North Fork Edisto River at Orangeburg, South Carolina (U.S. Geological Survey station 02173500), measured at upstream and downstream transects during routine and storm conditions, January 2014 to March 2015. $A$, dissolved nitrite plus nitrate. $B$, total nitrogen. $C$, total organic nitrogen plus ammonia. $D$, total phosphorus. $E$, suspended sediment. 

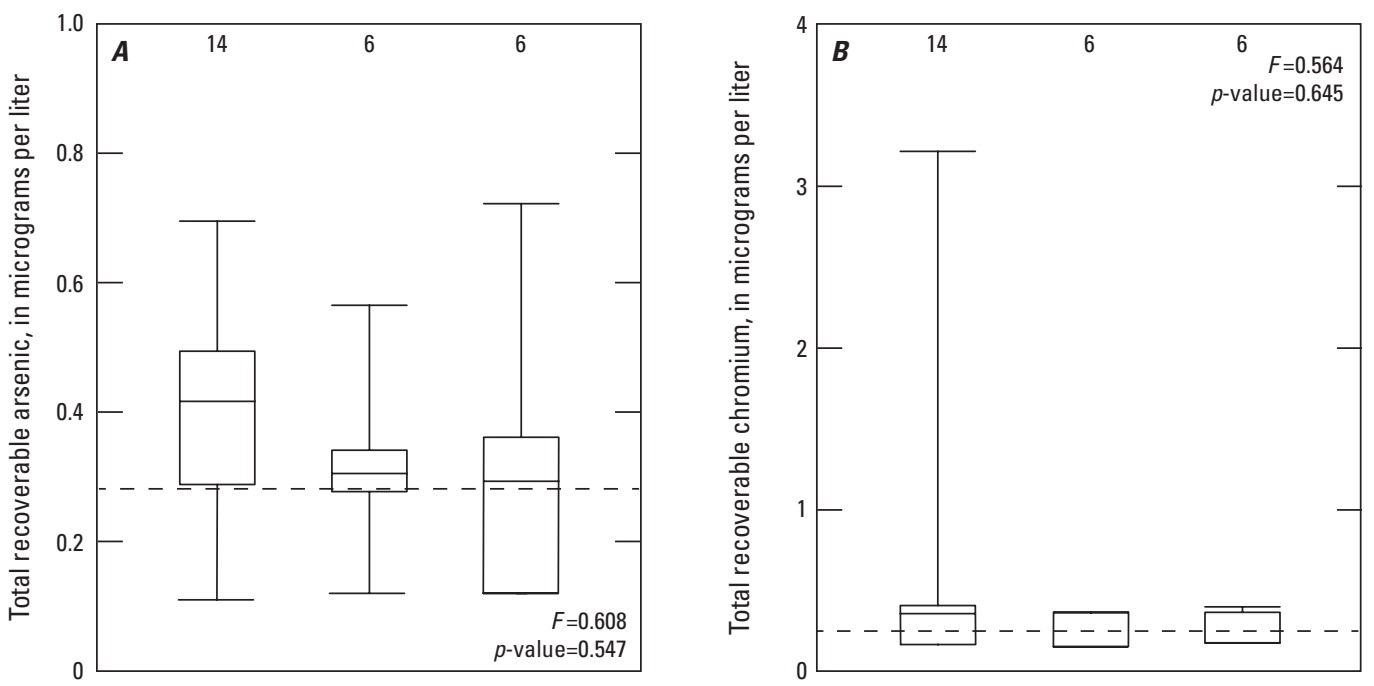

EXPLANATION

Number of samples

Maximum

75th percentile

Median

25th percentile

Minimum

- Laboratory reporting level

South Carolina Department of Health and Environmental Control criterion continuous concentration

Note: F, Fstatistic $p$-value, probability value NA, not applicable

US, upstream
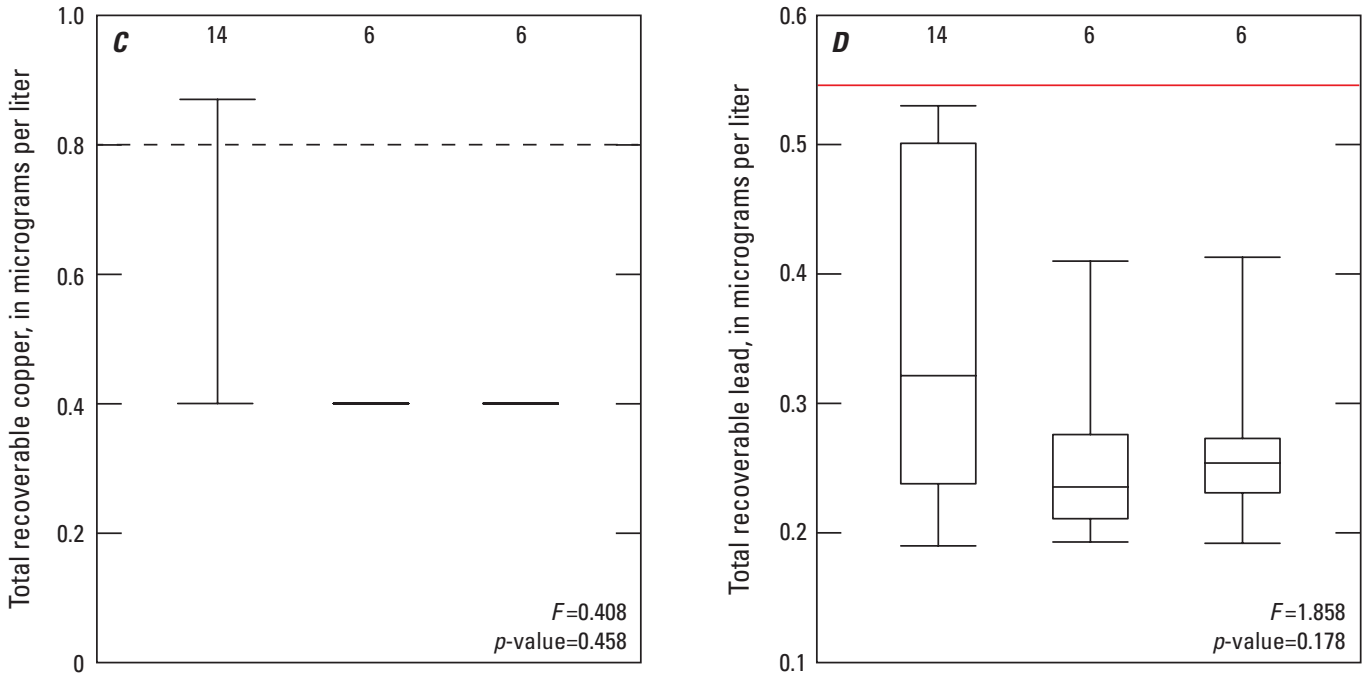

DS, downstream
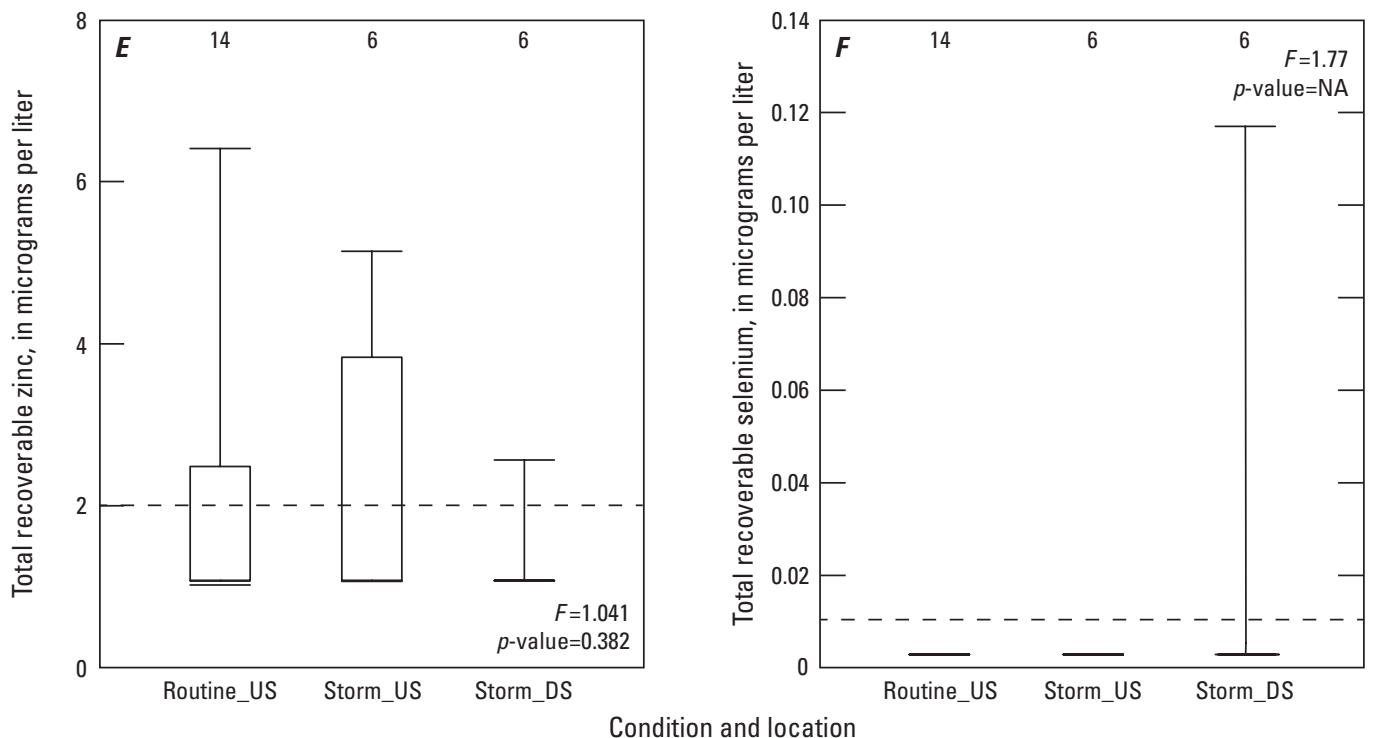

Figure 16. Boxplots showing total recoverable trace-metal concentrations in stream water at the North Fork Edisto River at Orangeburg, South Carolina (U.S. Geological Survey station 02173500), measured at upstream and downstream transects during routine and storm conditions, January 2014 to March 2015. A, arsenic. B, chromium. $C$, copper. $D$, lead.

E, zinc. F, selenium. 


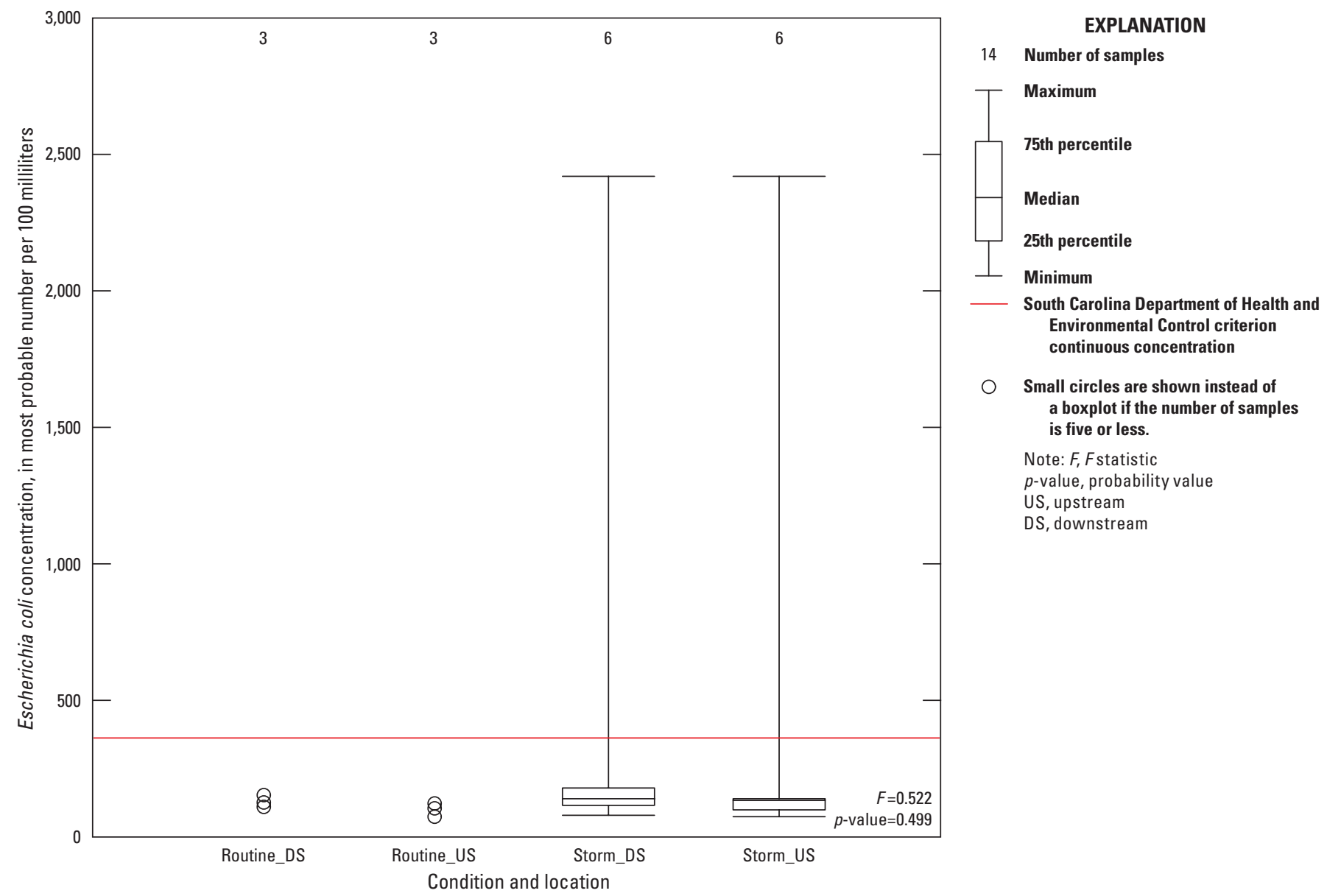

Figure 17. Boxplots showing Escherichia coli concentrations in stream water at the North Fork Edisto River at Orangeburg, South Carolina (U.S. Geological Survey station 02173500), measured at upstream and downstream transects during routine and storm conditions, January 2013 to March 2015. 
Table 11. Spearman rho correlation results for turbidity, Escherichia coli concentrations, and rainfall characteristics at transects upstream and downstream from the bridge, North Fork Edisto River at Orangeburg, South Carolina (U.S. Geological Survey station 02173500), for six storms from 2014 to 2015.

[Bold, italicized values represent statistically significant correlations $(\alpha=0.05)$; E. coli, Escherichia coli; NA, not applicable; Grey-shaded cells are the main diagonal of the correlation matrix, which represent the variable correlated perfectly with itself]

\begin{tabular}{|c|c|c|c|c|c|c|c|c|c|c|}
\hline Variables used in correlation & $\begin{array}{c}\text { Turbidity } \\
\text { upstream } \\
\text { from } \\
\text { bridge }\end{array}$ & $\begin{array}{c}\text { E. coli } \\
\text { upstream } \\
\text { from } \\
\text { bridge }\end{array}$ & $\begin{array}{c}\text { Turbidity } \\
\text { downstream } \\
\text { from bridge }\end{array}$ & $\begin{array}{c}\text { E. coli } \\
\text { downstream } \\
\text { from bridge }\end{array}$ & $\begin{array}{c}\text { Downstream } \\
\text { change in } \\
\text { turbidity }\end{array}$ & $\begin{array}{c}\text { Downstream } \\
\text { change in } \\
\text { E. coli }\end{array}$ & $\begin{array}{l}\text { Rainfall } \\
\text { intensity }\end{array}$ & $\begin{array}{l}\text { Rainfall } \\
\text { amount }\end{array}$ & $\begin{array}{l}\text { Rainfall } \\
\text { duration }\end{array}$ & $\begin{array}{l}\text { Days } \\
\text { since last } \\
\text { rainfall }\end{array}$ \\
\hline \multicolumn{11}{|c|}{ Spearman's rho correlation coefficient } \\
\hline Turbidity upstream from bridge & 1.0000 & 0.5139 & 0.9537 & 0.5068 & -0.1158 & -0.6611 & -0.6123 & 0.6324 & 0.6681 & 0.1977 \\
\hline E. coli upstream from bridge & 0.5139 & 1.0000 & 0.5336 & 0.9999 & 0.0844 & -0.4017 & -0.5726 & 0.8119 & 0.9743 & 0.5368 \\
\hline Turbidity downstream from bridge & 0.9537 & 0.5336 & 1.0000 & 0.5269 & 0.1884 & -0.6451 & -0.6914 & 0.5031 & 0.6416 & 0.0060 \\
\hline E. coli downstream from bridge & 0.5068 & 0.9999 & 0.5269 & 1.0000 & 0.0853 & -0.3886 & -0.5622 & 0.8120 & 0.9725 & 0.5332 \\
\hline Downstream change in turbidity & -0.1158 & 0.0844 & 0.1884 & 0.0853 & 1.0000 & 0.0282 & -0.2838 & -0.4032 & -0.0628 & -0.6254 \\
\hline Downstream change in E. coli & -0.6611 & -0.4017 & -0.6451 & -0.3886 & 0.0282 & 1.0000 & 0.8940 & -0.3179 & -0.5025 & -0.4441 \\
\hline Rainfall intensity & -0.6123 & -0.5726 & -0.6914 & -0.5622 & -0.2838 & 0.8940 & 1.0000 & -0.2577 & -0.6052 & -0.3575 \\
\hline Rainfall amount & 0.6324 & 0.8119 & 0.5031 & 0.8120 & -0.4032 & -0.3179 & -0.2577 & 1.0000 & 0.8858 & 0.5972 \\
\hline Rainfall duration & 0.6681 & 0.9743 & 0.6416 & 0.9725 & -0.0628 & -0.5025 & -0.6052 & 0.8858 & 1.0000 & 0.5895 \\
\hline Days since last rainfall & 0.1977 & 0.5368 & 0.0060 & 0.5332 & -0.6254 & -0.4441 & -0.3575 & 0.5972 & 0.5895 & 1.0000 \\
\hline \multicolumn{11}{|c|}{ Probability values } \\
\hline Turbidity upstream from bridge & NA & 0.2970 & 0.0032 & 0.3049 & 0.8271 & 0.1528 & 0.1963 & 0.1779 & 0.1470 & 0.7074 \\
\hline E. coli upstream from bridge & 0.2970 & NA & 0.2755 & $<0.001$ & 0.8738 & 0.4299 & 0.2350 & 0.0497 & 0.001 & 0.2721 \\
\hline Turbidity downstream from bridge & 0.0032 & 0.2755 & NA & 0.2828 & 0.7207 & 0.1666 & 0.1282 & 0.3090 & 0.1697 & 0.9910 \\
\hline E. coli downstream from bridge & 0.3049 & $<0.001$ & 0.2828 & NA & 0.8723 & 0.4464 & 0.2455 & 0.0497 & 0.0011 & 0.2760 \\
\hline Downstream change in turbidity & 0.8271 & 0.8738 & 0.7207 & 0.8723 & NA & 0.9576 & 0.5857 & 0.4279 & 0.9059 & 0.1842 \\
\hline Downstream change in E. coli & 0.1528 & 0.4299 & 0.1666 & 0.4464 & 0.9576 & NA & 0.0163 & 0.5392 & 0.3097 & 0.3777 \\
\hline Rainfall intensity & 0.1963 & 0.2350 & 0.1282 & 0.2455 & 0.5857 & 0.0163 & NA & 0.6221 & 0.2030 & 0.4866 \\
\hline Rainfall amount & 0.1779 & 0.0497 & 0.309 & 0.0497 & 0.4279 & 0.5392 & 0.6221 & NA & 0.0188 & 0.2107 \\
\hline Rainfall duration & 0.1470 & 0.001 & 0.1697 & 0.0011 & 0.9059 & 0.3097 & 0.2030 & 0.0188 & NA & 0.2181 \\
\hline Days since last rainfall & 0.7074 & 0.2721 & 0.9910 & 0.2760 & 0.1842 & 0.3777 & 0.4866 & 0.2107 & 0.2181 & NA \\
\hline
\end{tabular}




\section{Turkey Creek}

In total, 14 routine (nonstorm) and 10 storm samples were collected from Turkey Creek at the Turkey bridge site from April 2015 to March 2017 (table 3; appendix table 3.3; Romanok and others, 2020). Streamflow varied from 0 to $57 \mathrm{ft}^{3} / \mathrm{s}$ at the time of storm sampling and from 0 to $58 \mathrm{ft}^{3} / \mathrm{s}$ at the time of routine sampling for the Turkey bridge site (table 2; appendix table 3.3; fig. 18A; Romanok and others, 2020). The sampled streamflow conditions covered the range of daily streamflow conditions of 0 to $39.4 \mathrm{ft}^{3} / \mathrm{s}$ for the period of record at Turkey bridge site (table 1). Precipitation at the Turkey bridge site was only in the form of rainfall during the period of study. Rainfall amounts of the sampled storms ranged from 0.02 to $0.06 \mathrm{in}$. with intensities that ranged from 0.01 to $0.13 \mathrm{in} / \mathrm{hr}$ (table 2; fig. 18B). Antecedent conditions ranged from 1 to 7 days since last rainfall. The Turkey bridge site had mean potential bridge-deck runoff rates (bridge discharges) for each storm ranging from 0.002 to $0.016 \mathrm{ft}^{3} / \mathrm{s}$. However, because of much lower flow conditions, the ratio of bridge-deck runoff to streamflow ranged from 0.004 to 100 percent at the time of sampling (table 2). Storm 2 on June 6, 2016, probably represented the greatest potential for impact because Turkey River had extremely low-flow conditions (no measurable flow) producing 100 percent bridge-deck runoff contribution to streamflow, even though the storm had low intensity $(0.05 \mathrm{in} /$ $\mathrm{hr}$ ) and rainfall (0.06 in.) amounts with 1 day since last rainfall (table 2). Of the storms sampled at this site, those conditions provided limited dilution capacity of the river.

At the Turkey bridge site, a one-time sampling of the accumulated sediment on the bridge deck near the storm drainage systems (downspouts and vertical openings) was conducted in July 2015 during the period of water sampling (table 3). Streambed sediment was sampled once (August 2015), and Hester-Dendy artificial substrates were deployed (July 2015) at transects downstream and upstream from the Turkey bridge site.

Specific conductance measurements made at the Turkey bridge site ranged from 33 to $103 \mu \mathrm{S} / \mathrm{cm}$ during the sampling period, indicative of waters with low ionic strength (appendix table 3.3; fig. 19A; Romanok and others, 2020). Turbidity levels remained well below the SCDHEC criterion of 50 NTU, ranging from 5.0 to $26.5 \mathrm{FNU}$ during storm and routine samplings (fig. 19B). At the Turkey bridge site, $\mathrm{pH}$ ranged from 4.6 to $6.7 \mathrm{SU}$ and had median values of 5.5, 6.0, and 5.8 for routine, storm_US, and storm_DS samples, respectively (fig. 19C), indicating a large percentage (around 50 percent) of samples falling below the minimum $\mathrm{pH}$ criterion of 6.0 (appendix table 3.3; Romanok and others, 2020). However, low $\mathrm{pH}$ and ionic strength waters are common in Coastal Plain streams in South Carolina and were considered a natural condition (South Carolina Department of Health and Environmental Control, 2014c). DO concentrations were highly variable and dependent on streamflow and season, ranging from 0.7 to $12.3 \mathrm{mg} / \mathrm{L}$ during the study period. Median DO concentrations for routine, storm_US, and
storm_DS samples were $5.3,7.5$, and $7.4 \mathrm{mg} / \mathrm{L}$, respectively, and above the SCDHEC criterion of minimum DO concentration of $4 \mathrm{mg} / \mathrm{L}$ (appendix table 3.3; fig. 19D; table 4; Romanok and others, 2020). However, DO frequently fell to below $4 \mathrm{mg} / \mathrm{L}$ under low streamflow conditions (less than $1 \mathrm{ft}^{3} / \mathrm{s}$ ) during the summer months (May to August) when minimal reaeration occurred (Romanok and others, 2020).

Permutation one-factor tests that compared SC, $\mathrm{pH}, \mathrm{DO}$, and turbidity measurements among routine, storm_US, and storm_DS samples at the Turkey bridge site determined that the within-group variation was greater than the among-group variation for these water-quality data ( $p$-value $>0.05$; table 9 ). These results indicated that bridge-deck runoff during storms at the Turkey bridge site did not significantly alter physical properties of SC, $\mathrm{pH}, \mathrm{DO}$, and turbidity in Turkey Creek at the downstream and upstream transects from the ambient conditions at the upstream transect (figs. 19A-D). Although dissolved chloride concentrations were greater during routine conditions as compared to storm conditions at Turkey Creek, the difference was not great enough to alter SC (table 9). The Wilcoxon one-sided signed rank test was applied to $\mathrm{SC}, \mathrm{pH}$, $\mathrm{DO}$, and turbidity measurements in stream water at the paired downstream and upstream transects to determine whether the transect downstream from the bridge consistently had greater concentrations in its stream water than the transect upstream from the bridge for all storms (table 10). Results of the signed rank test indicated that the field measurements of all four properties did not increase during storms downstream from the bridge (all $p$-values $>0.05$ ).

At the Turkey bridge site, TN concentrations ranged from 0.49 to $3.07 \mathrm{mg} / \mathrm{L}$ in all samples (appendix table 3.3; Romanok and others, 2020). Median TN concentrations of $0.86,0.62$, and $0.60 \mathrm{mg} / \mathrm{L}$ in routine, storm_US, and storm_DS samples, respectively, demonstrated little variability (appendix table 3.3; fig. 20A; Romanok and others, 2020). TN concentrations consisted almost entirely of TKN because of infrequent detections of $\mathrm{NO}_{2}+\mathrm{NO}_{3}$. Median TKN concentrations were $0.82,0.58$, and $0.56 \mathrm{mg} / \mathrm{L}$, in routine, storm_US, and storm_DS samples, respectively (appendix table 3.3; fig. 20B; Romanok and others, 2020), whereas median $\mathrm{NO}_{2}+\mathrm{NO}_{3}$ concentrations were less than $0.04 \mathrm{mg} / \mathrm{L}$, respectively (fig. 12C).

At the Turkey bridge site, median TP concentrations were $0.044,0.028$, and $0.026 \mathrm{mg} / \mathrm{L}$, and median SSCs were $15,15.5$, and $16 \mathrm{mg} / \mathrm{L}$ in routine, storm_US, and storm_DS samples, respectively (appendix table 3.3; figs. $20 D$, $E$; Romanok and others, 2020). Nutrient and SSCs in storm samples were within or below the range of nutrient concentrations in routine samples at the Turkey bridge site, with the exception of June 6, 2016, storm that occurred during a period of low streamflow conditions when maximum nutrient concentrations were observed (figs. 20A-D).

Results of the permutation one-factor tests determined that the within-group variation was greater than the amonggroup variation for these water-quality data, producing a low $F$ statistic and $p$-value above 0.05 . These results indicated that 
bridge-deck runoff during storms at the Turkey bridge site did not significantly alter nutrient and SSCs in Turkey Creek at the downstream and upstream transects compared to the ambient conditions at the upstream transect (figs. 20A-E). Results of the Wilcoxon one-sided signed rank indicated that there was no statistically significant increase in nutrient and SSCs downstream from the bridge at the Turkey bridge site during storms (all $p$-values $>0.05$; table 10 ).

At the Turkey Creek bridge site, trace metals (except for cadmium) were detected frequently in stream water during routine and storm samplings. Based on a hardness range of about 8.3 to $32.8 \mathrm{mg} / \mathrm{L}$ at the Turkey bridge site, total recoverable chromium, zinc, arsenic, and mercury concentrations were consistently below the SCDHEC CMC and $\mathrm{CCC}$ for aquatic life established for Turkey River freshwater use (table 4; appendix table 3.3; figs. 21A-F; Romanok and others, 2020). Lead (total and filtered) was the most frequently detected metal, followed by arsenic, chromium, zinc, and mercury. Total recoverable lead concentrations in the stream ranged from 0.52 to $4.17 \mu \mathrm{g} / \mathrm{L}$ and exceeded the CCC for aquatic life $(0.54 \mu \mathrm{g} / \mathrm{L})$ in almost every sample (except for the upstream transect during the February 2017 storm). Additionally, the total lead concentration at the downstream transect $(2.26 \mu \mathrm{g} / \mathrm{L})$ was elevated relative to the upstream transect $(0.74 \mu \mathrm{g} / \mathrm{L})$ during the January 2016 storm, only, which had one of the greatest streamflows. A routine sample of stream water taken at the upstream transect at the Turkey bridge site on April 28, 2016, had a total recoverable copper concentration of $6.70 \mu \mathrm{g} / \mathrm{L}$ that exceeded the CMC and CCC aquatic life criteria (3.8 and $2.9 \mu \mathrm{g} / \mathrm{L}$, respectively). Also, during one routine sampling, total recoverable cadmium concentration of $0.29 \mu \mathrm{g} / \mathrm{L}$ and total selenium of $5.11 \mu \mathrm{g} / \mathrm{L}$ were detected on April 5, 2016, at the upstream transect at the Turkey bridge site, which exceeded the CCC of 0.1 and $5 \mu \mathrm{g} / \mathrm{L}$, respectively (appendix table 3.3; Romanok and others, 2020). Therefore, at the Turkey bridge site, several trace metals (lead, copper, selenium, and cadmium) had concentrations in stream water that exceeded aquatic-life criteria, but exceedances tended to occur more frequently during routine (nonstorm-related) sampling.

Permutation one-factor tests were run on the trace-metal data to compare concentrations among routine, storm_US, and storm_DS samples to determine if statistical differences were present. Results of the tests indicated 2 of the 16 trace metals had concentrations that varied among the 3 sample groups. Dissolved (filtered) zinc and selenium concentrations were statistically greater in routine samples (upstream transect) than in storm samples (both upstream and downstream transects) (filtered zinc, $F=5.76, p$-value $=0.013$; filtered selenium, $F=0.374, p$-value $=0.035$; table 9). Even with these statistical differences, the overall results indicated that bridge-deck runoff at the Turkey bridge site did not significantly alter tracemetal concentrations in Turkey River at the downstream and upstream transects compared to the ambient conditions at the upstream transect (no bridge influence) transect (figs. 21A-F).
Dissolved and total trace-metal concentrations in stream water were tested using Wilcoxon one-sided signed rank test at the paired downstream and upstream transects for each storm to determine whether the transect downstream from the bridge had significantly greater concentrations in its stream water than the transect upstream from the bridge for all storms. Total chromium concentrations were statistically higher at the downstream transect relative to the upstream transect during the five storms $(Z=2.023$, $p$-value $=0.030$; table 10). All other trace-metal concentrations did not increase downstream from the bridge at the Turkey bridge site during storms (table 10).

At the Turkey bridge site during the period of study, $E$. coli concentrations were periodically above the SCDHEC criterion of $349 \mathrm{MPN} / 100 \mathrm{~mL}$ during routine and storm sampling (table 4; appendix table 3.3; fig. 22; Romanok and others, 2020). Composite samples (only) collected during routine, nonstorm conditions at upstream and downstream transects at the Turkey bridge site were compared to composite samples collected during storms at the same transects (fig. 22). Routine composite samples (upstream and downstream transects) had E. coli concentrations that ranged from 131 to $461 \mathrm{MPN} / 100 \mathrm{~mL}$, whereas storm samples ranged from 8 to $816 \mathrm{MPN} / 100 \mathrm{~mL}$ (upstream transect) and 99 to $818 \mathrm{MPN} / 100 \mathrm{~mL}$ (downstream transect; appendix table 3.3; fig. 22; Romanok and others, 2020). Median $E$. coli concentrations were 227, 108, and $161 \mathrm{MPN} / 100 \mathrm{~mL}$ in routine, storm_US, and storm_DS samples, respectively (appendix table 3.3; Romanok and others, 2020). Although the range of concentrations for the storms seemed to be elevated relative to the routine conditions, permutation one-factor tests indicated that there were no statistically significant differences in $E$. coli concentrations between nonstorm and storm conditions (table $9 ; F=0.037 ; p$-value $=0.991$ ). Additionally, results of the Wilcoxon one sided paired test indicated that there was no statistically significant increase in E. coli concentrations downstream from the bridge at the Turkey bridge site during storms (table 10; $Z=1.483 ; p$-value $=0.092$ ).

Detections of PAHs in stream water were observed during 4 routine (upstream transect only) and 2 storm (upstream and downstream transects) samplings at the Turkey bridge site (appendix table 3.3; Romanok and others, 2020). Seven of 17 PAHs were detected at least once: fluorene (5 detections), acenaphthene ( 8 detections), chrysene (1 detection), dibenzo[ $a, h]$ anthracene (1 detection), fluoranthene (1 detection), naphthalene (6 detections), and phenanthrene (6 detections) (Romanok and others, 2020). All detections were observed in samples collected during streamflow conditions below $0.6 \mathrm{ft}^{3} / \mathrm{s}$ (range was 0 to $0.52 \mathrm{ft}^{3} / \mathrm{s}$ ). Concentrations of the detected PAHs were below their LRLs by an order of magnitude. Routine samples on August 25, 2015, and April 28, 2016, during extremely low-flow conditions ( 0 and $0.01 \mathrm{ft}^{3} / \mathrm{s}$, respectively) had the maximum of five PAHs detected at the Turkey bridge site with $\Sigma \mathrm{PAH}_{17}$ of 0.122 and $0.171 \mu \mathrm{g} / \mathrm{L}$, respectively (Romanok and others, 2020). The storm sample on June 6, 2016, had the maximum number of detections of four and maximum 
$\Sigma \mathrm{PAH}_{17}$ concentrations of 0.369 and $0.378 \mu \mathrm{g} / \mathrm{L}$ at the downstream and upstream transects, respectively. The storm sample on March 13, 2017, had two detections with a $\Sigma \mathrm{PAH}_{17}$ concentrations of 0.057 and $0.054 \mu \mathrm{g} / \mathrm{L}$ at the downstream and upstream transects, respectively. The Turkey bridge site had detectable naphthalene and acenaphthene concentrations during both storms; the June 6, 2016, storm also had detectable concentrations of fluorene and phenathrene.
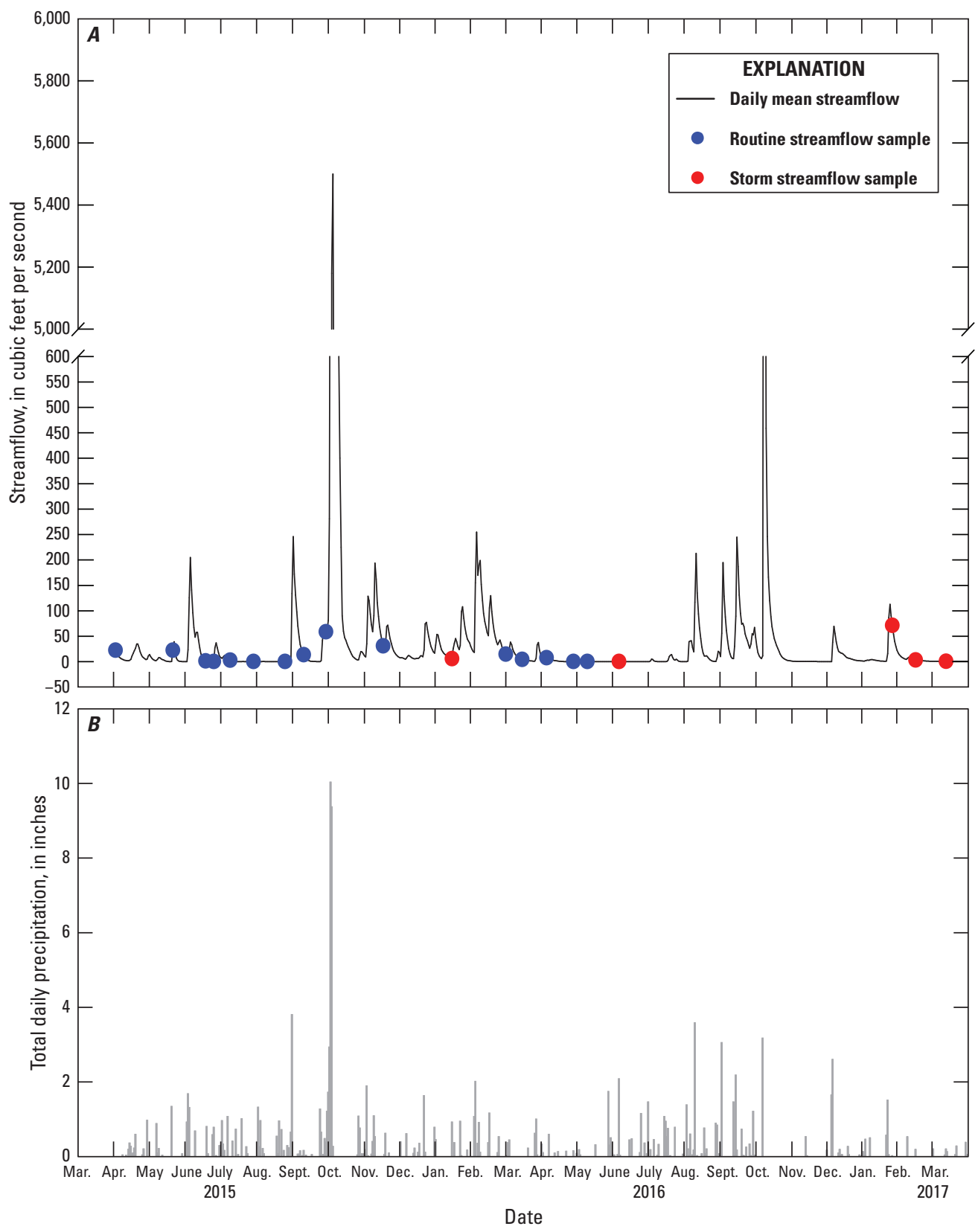

Figure 18. Graphs showing a time series of, $A$, daily mean streamflow and instantaneous streamflow during sampling and, $B$, total daily precipitation at Turkey Creek above Huger, South Carolina (U.S. Geological Survey station 02172035), from March 2015 to April 2017. 

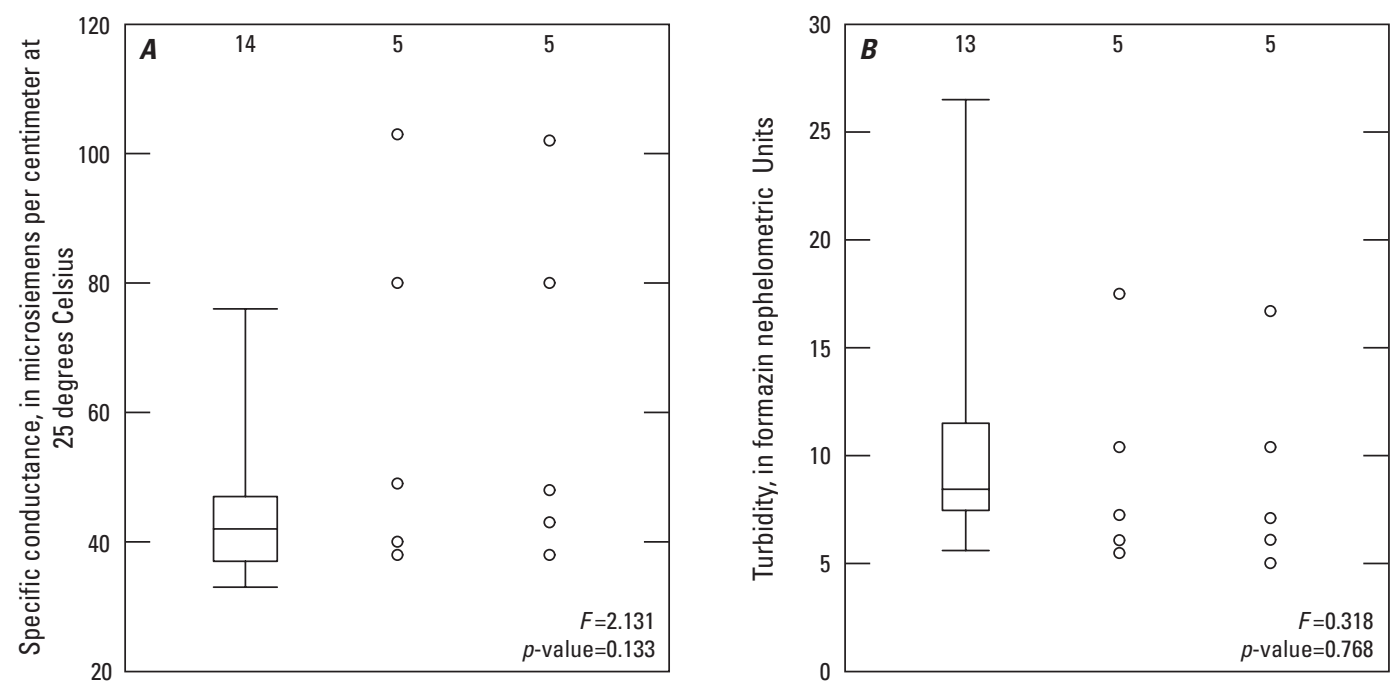

14 Number of samples

Maximum
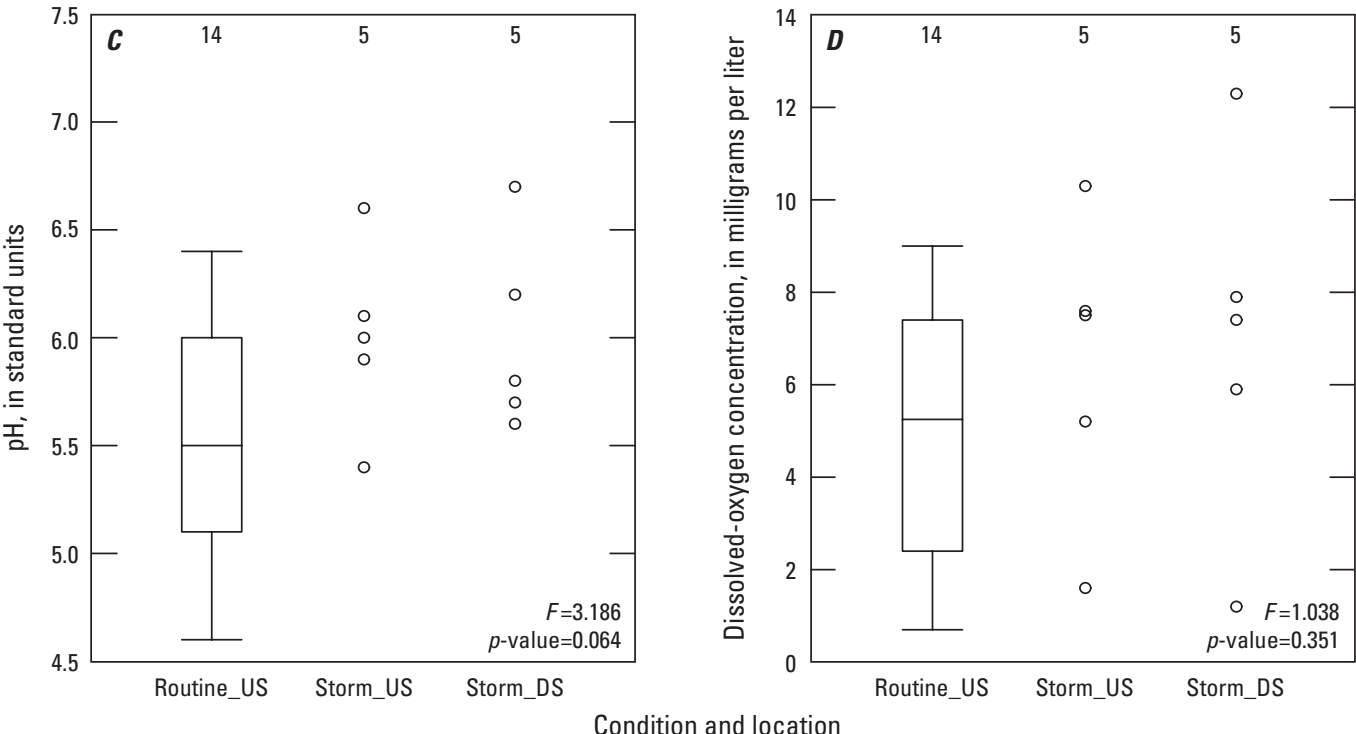

75th percentile

Median

25th percentile

Minimum

Note: Small circles are shown instead of a boxplot if the number of samples is five or less. The number beside the circle means that there is more than one sample at that location. $F, F$ statistic $p$-value, probability value US, upstream DS, downstream

Figure 19. Boxplots showing field properties in stream water at Turkey Creek above Huger, South Carolina (U.S. Geological Survey station 02172035), measured at upstream and downstream transects during routine and storm conditions, April 2015 to March 2017. $A$, specific conductance. $B$, turbidity. $C, \mathrm{pH} . D$, dissolved oxygen. 

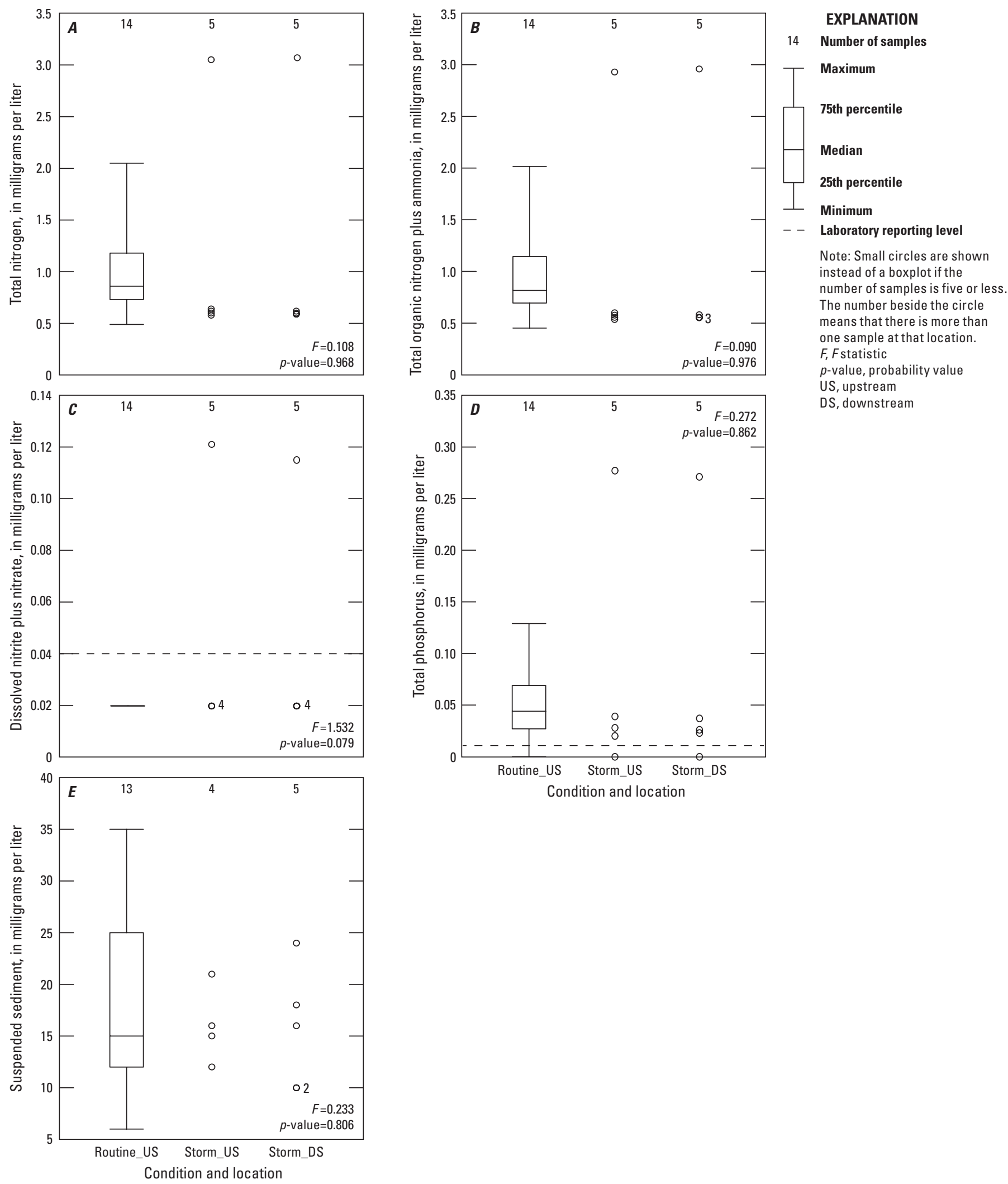

Condition and location

Figure 20. Boxplots showing nutrient and suspended-sediment concentrations in stream water at Turkey River above Huger, South Carolina (U.S. Geological Survey station 02172035), measured at upstream and downstream transects during routine and storm conditions, April 2015 to March 2017. $A$, total nitrogen. $B$, total organic nitrogen plus ammonia. $C$, dissolved nitrite plus nitrate. $D$, total phosphorus. $E$, suspended sediment. 

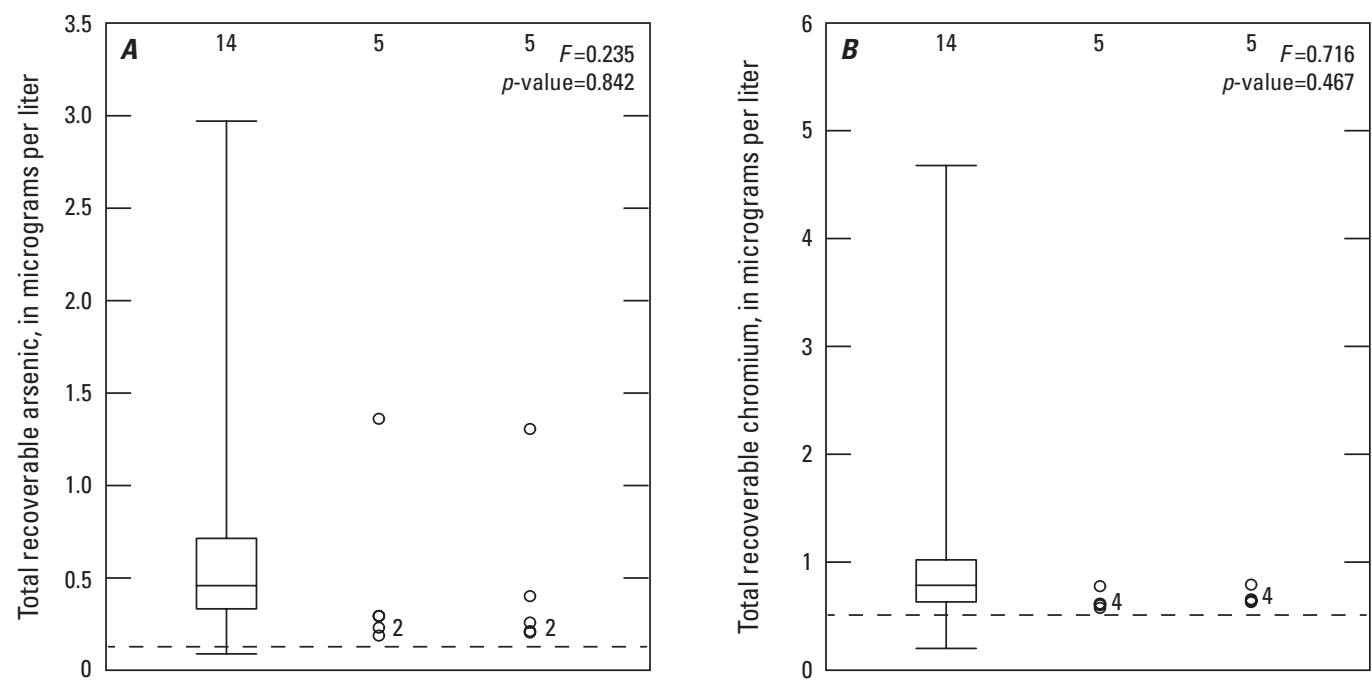

EXPLANATION

Number of samples

Maximum

75th percentile

Median

25th percentile

Minimum

- - Laboratory reporting level

South Carolina Department of Health and Environmental Control (SCDHEC) criterion maximum concentration of 3.8 micrograms per liter $(\mu \mathrm{g} / \mathrm{L})$

South Carolina Department of Health and Environmental Control (SCDHEC) criterion continuous concentration of $0.54 \mu \mathrm{g} / \mathrm{L}$

Note: Small circles are shown instead of a boxplot if the number of samples is five or less. The number beside the circle means that there is more than one sample at that location. $F$, Fstatistic

$p$-value, probability value

US, upstream

DS, downstream
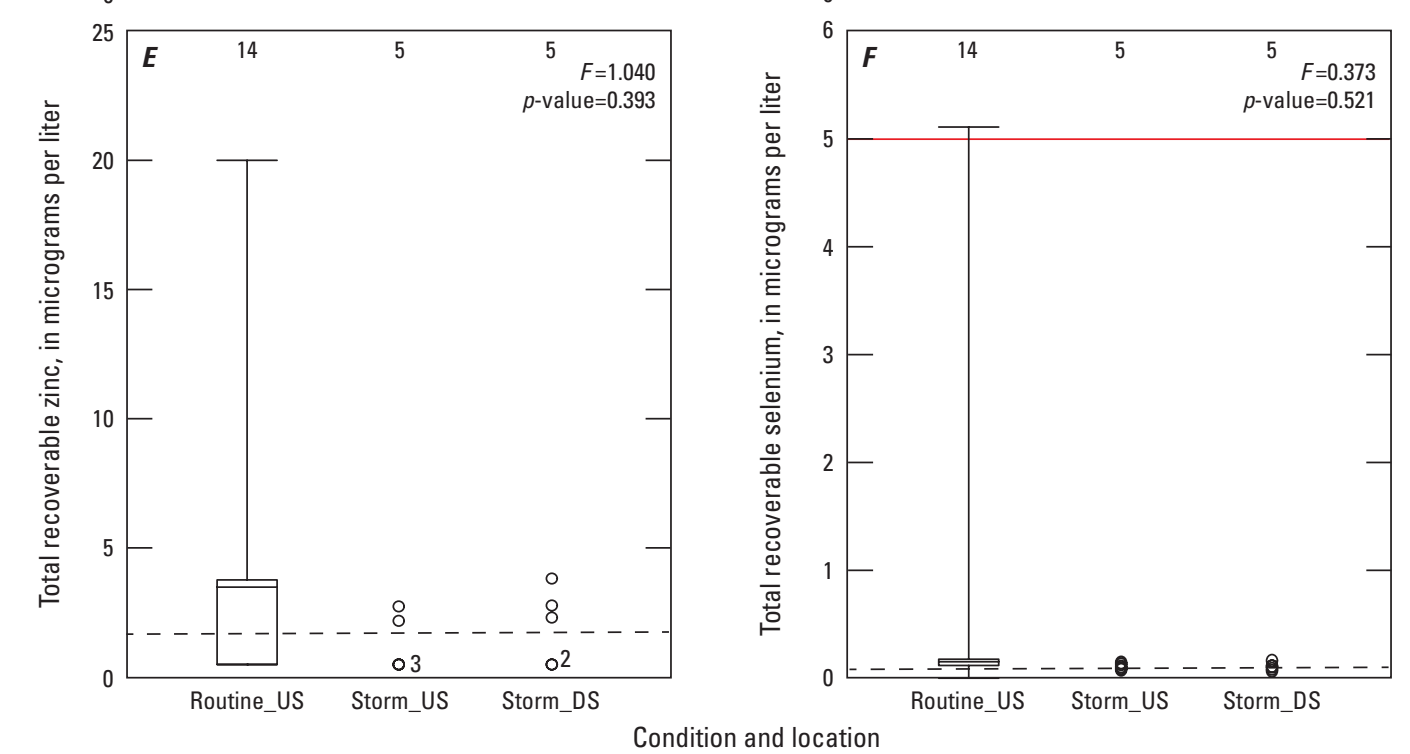

Figure 21. Boxplots showing total recoverable trace-element concentrations in stream water at Turkey River above Huger, South Carolina (U.S. Geological Survey station 02172035), measured at upstream and downstream transects during routine and storm conditions, April 2015 to March 2017. A, arsenic. B, chromium. C, copper. D, lead. E, zinc. F, selenium. 


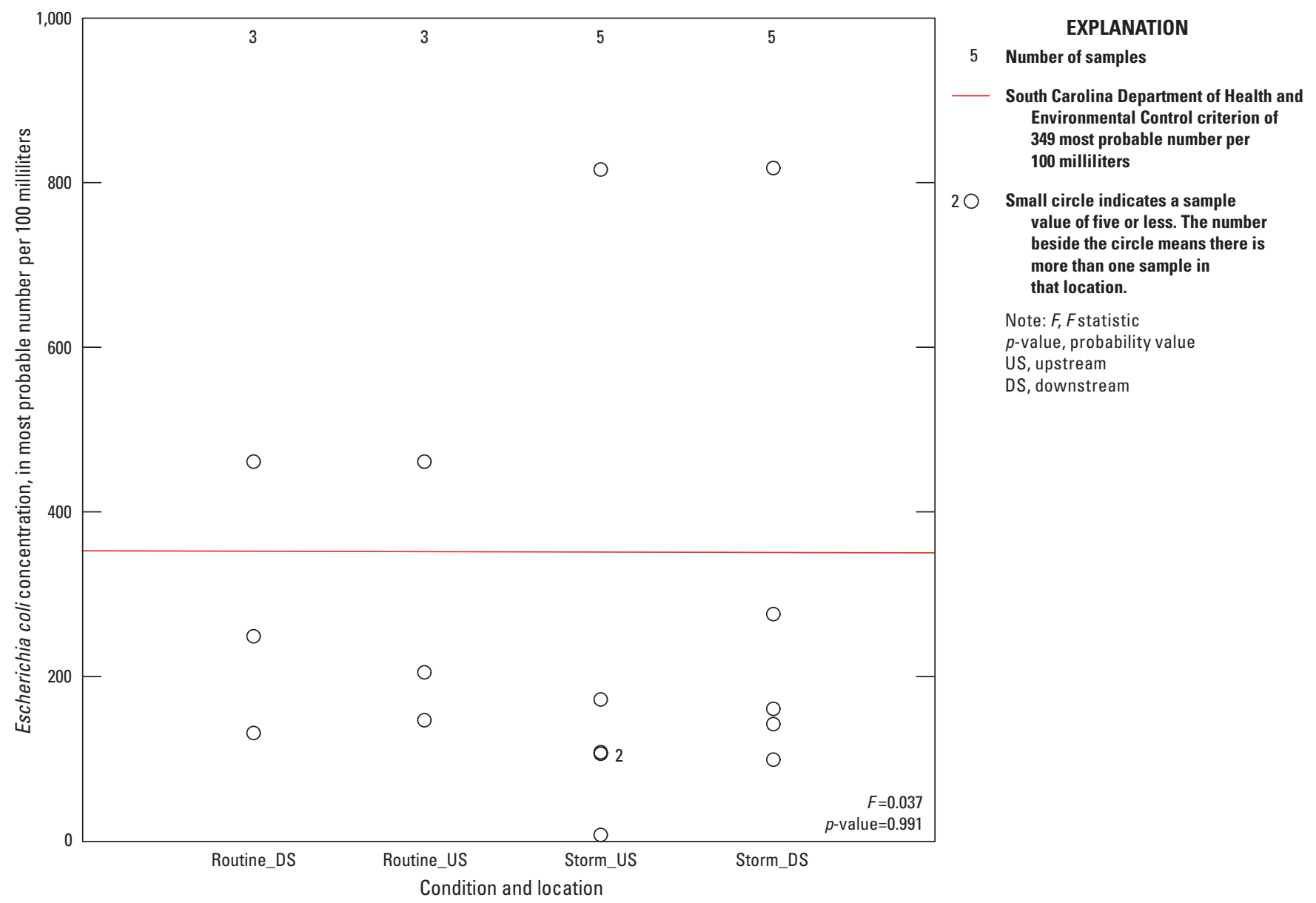

Figure 22. Boxplots showing Escherichia coli concentrations in stream water at Turkey Creek above Huger, South Carolina (U.S. Geological Survey station 02172035), measured at upstream and downstream transects during routine and storm conditions, March 2015 to April 2017.

\section{South Fork Edisto River}

In total, 14 routine (nonstorm) and 10 storm samples were collected from South Fork Edisto River at the SFEdisto bridge site from April 2015 to May 2016 (table 3; appendix table 3.4; Romanok and others, 2020). Streamflow ranged from 288 to $825 \mathrm{ft}^{3} / \mathrm{s}$ at the time of storm sampling and from 164 to $1,110 \mathrm{ft}^{3} / \mathrm{s}$ at the time of routine sampling (table 2; fig. $23 \mathrm{~A}$ ). The range in sampled flows compared was on the low end of the range of daily mean flows for the period of record at the SFEdisto bridge site of 110 to $12,700 \mathrm{ft}^{3} / \mathrm{s}$ (table 1). Precipitation at the SFEdisto bridge site was only in the form of rainfall during the period of study. Rainfall amounts of the sampled storms ranged from 0.03 to 0.13 in. with intensities that ranged from 0.04 to $0.25 \mathrm{in} / \mathrm{hr}$; table 2; fig. $23 B$ ). Antecedent conditions ranged from 2 to 12 days since last rainfall. The mean potential bridge-deck runoff rate (bridge discharge) for each storm was estimated to range from 0.009 to $0.059 \mathrm{ft}^{3} / \mathrm{s}$, representing a ratio of bridge-deck runoff rate to streamflow that was 0.003 to 0.009 percent at the time of sampling (table 2). These minor bridge-deck runoff contributions suggested a strong potential for dilution of any storm runoff entering the stream from the bridge. Storm 3 on December 2, 2015, probably represented the greatest potential of impact because the South Fork Edisto River had intermediate flow conditions $\left(623 \mathrm{ft}^{3} / \mathrm{s}\right)$ with 10 days since last rainfall, greater rainfall intensity $(0.22 \mathrm{in} / \mathrm{hr})$ and rainfall (0.13 in.) amounts (table 2). Of the storms sampled at this site, those conditions provided the least dilution capacity of the river with a good opportunity for accumulation of contaminants on the bridge deck before rainfall and potential of wash-off of those contaminants during rainfall.

At SFEdisto bridge site, a one-time sampling of the accumulated sediment on the bridge deck near the storm drainage systems (downspouts and vertical openings) was conducted in July 2015 during the start of water sampling (table 3). At the beginning of the water sampling period, streambed sediment was sampled once (August 2015) and Hester-Dendy artificial substrates were deployed (July 2015) at transects downstream and upstream from the SFEdisto bridge site.

Specific conductance measurements made at SFEdisto bridge site ranged from 25 to $39 \mu \mathrm{S} / \mathrm{cm}$ during the sampling period, indicative of waters with low ionic strength (appendix 
table 3.4; fig. 24A; Romanok and others, 2020). Turbidity levels remained well below the SCDHEC criterion of $50 \mathrm{NTU}$, ranging from 4.1 to $14.9 \mathrm{FNU}$ during storm and routine samplings (fig. 24B). At the SFEdisto bridge site, $\mathrm{pH}$ ranged from 5.5 to $6.4 \mathrm{SU}$ and had a median of $6.0 \mathrm{SU}$ (fig. 24C). DO concentrations ranged from 5.8 to $8.5 \mathrm{mg} / \mathrm{L}$ at the time of sampling during the study period and were above the SCDHEC criterion of minimum DO above $4 \mathrm{mg} / \mathrm{L}$ (fig. 24D; table 4). Although median $\mathrm{pH}$ was within the SCHDEC range of 6 to 9, some $\mathrm{pH}$ values fell below 6 . However, low $\mathrm{pH}$ and ionic strength waters are common in Coastal Plain streams in South Carolina and were considered a natural condition (South Carolina Department of Health and Environmental Control, 2012a).

Permutation one-factor tests were run to compare $\mathrm{SC}, \mathrm{pH}$, DO, and turbidity measurements among routine, storm_US, and storm_DS sample groups. Permutation-derived $F$ statistics and $p$-values determined that the within-group variation was greater than the among-group variation for these water-quality data (table 9). These results indicated that bridge-deck runoff at the SFEdisto bridge site did not significantly alter physical properties of $\mathrm{SC}, \mathrm{pH}, \mathrm{DO}$, and turbidity in the South Fork Edisto River at the downstream and upstream transects compared to the ambient conditions at the upstream transect at the SFEdisto bridge site (figs. 24A-D). The Wilcoxon one-sided signed rank test also indicated that the field measurements of $\mathrm{SC}, \mathrm{pH}$, and turbidity did not increase during storms downstream from the bridge (all $p$-values $>0.05$; table 10 ).

At the SFEdisto bridge site, TN concentrations ranged from 0.44 to $0.98 \mathrm{mg} / \mathrm{L}$ in all samples (appendix table 3.4; Romanok and others, 2020). Median TN concentrations of $0.66,0.72$, and $0.68 \mathrm{mg} / \mathrm{L}$ in routine, storm_US, and storm_DS samples, respectively, demonstrated little variability (appendix table 3.4; fig. 25A; Romanok and others, 2020). TN concentrations consisted of species of $\mathrm{NO}_{2}+\mathrm{NO}_{3}$ and TKN concentrations. Median TKN concentrations were $0.51,0.53$, and $0.56 \mathrm{mg} / \mathrm{L}$, in routine, storm_US, and storm_DS samples, respectively (appendix table 3.4; fig. $25 B$; Romanok and others, 2020), whereas median $\mathrm{NO}_{2}+\mathrm{NO}_{3}$ concentrations were about five times lower at $0.16,0.15$, and $0.10 \mathrm{mg} / \mathrm{L}$, respectively (fig. 25C).

At the SFEdisto bridge site, median TP concentrations were $0.043,0.047$, and $0.046 \mathrm{mg} / \mathrm{L}$, and median SSCs were 12,9 , and $9 \mathrm{mg} / \mathrm{L}$ in routine, storm_US, and storm_DS samples, respectively (appendix table 3.4; figs. 25D, E; Romanok and others, 2020). Overall, there were no observable changes in range of nutrient or SSCs in storm_DS samples compared to the other sample groups.

Permutation one-factor statistics and $p$-values determined that the within-group variations of nutrient and SSCs were greater than the among-group variations for these waterquality data (table 9). These results indicated that bridge-deck runoff did not significantly alter nutrient and SSCs in the South Fork Edisto River at the transects downstream and upstream from the SFEdisto bridge site compared to the ambient conditions at the upstream transect (figs. 25A-E). The
Wilcoxon one-sided signed rank test results also indicated that there were no statistically significant increases in nutrient and SSCs downstream from the bridge at the SFEdisto bridge site during storms (all $p$-values $>0.05$; table 10 ).

Except for cadmium, detectable concentrations of trace metals were observed in stream water during routine and storm samplings. Based on a median hardness of about $9 \mathrm{mg} / \mathrm{L}$ at the SFEdisto bridge site, total recoverable chromium, copper, zinc, arsenic, mercury, and selenium concentrations were consistently below the SCDHEC CMC and CCC for aquatic life established for South Fork Edisto River freshwater use (table 4; appendix table 3.4; figs. 26A-F; Romanok and others, 2020). Lead (total and filtered) was the most frequently detected metal, followed by arsenic, selenium, chromium, zinc, mercury, and copper. Total recoverable lead concentrations frequently exceeded CCC criterion of $0.54 \mu \mathrm{g} / \mathrm{L}$. Specifically, CCC criterion for lead was exceeded in 7 of the 14 routine samples (upstream transect) and in 2 of the 5 storm samples (upstream and downstream transects; fig. 26D; Romanok and others, 2020).

Permutation one-factor statistics (signal-to-noise ratio) and $p$-values determined that the within-group variations of trace-metal concentrations were greater than the among-group variations for these water-quality data (table 9). These results indicated that bridge-deck runoff at the SFEdisto bridge site did not significantly alter trace-metal concentrations in the South Fork Edisto River at transects downstream and upstream from the SFEdisto bridge site compared to the ambient conditions at the upstream transect (figs. 26A-F). The Wilcoxon one-sided signed rank test results also indicated that there were no statistically significant increases in trace-metal concentrations downstream from the bridge at the SFEdisto bridge site during storms (all $p$-values $>0.05$; table 10 ).

At the SFEdisto bridge site during the period of study, E. coli concentrations were below the SCDHEC criterion of 349 MPN/100 mL, except during the September 24, 2015, storm when concentrations were 387 and 373 MPN/100 $\mathrm{mL}$ at upstream and downstream transects, respectively (table 4; appendix table 3.4; fig. 27; Romanok and others, 2020). Composite samples (only) collected during routine, nonstorm conditions at upstream and downstream transects at the SFEdisto bridge site were compared to composite samples collected during storms at the same transects. Routine composite samples (upstream and downstream transects) had E. coli concentrations that ranged from 65 to $152 \mathrm{MPN} / 100 \mathrm{~mL}$, whereas storm samples ranged from 62 to $387 \mathrm{MPN} / 100 \mathrm{~mL}$ (upstream transect) and 77 to 373 MPN/100 mL (downstream transect; appendix table 3.4; Romanok and others, 2020). Median E. coli concentrations were 103,152 , and $147 \mathrm{MPN} / 100 \mathrm{~mL}$ in routine, storm_US, and storm_DS samples, respectively (appendix table $3 . \overline{4}$; Romanok and others, 2020). Although the range of concentrations for the storms was elevated relative to the routine conditions, permutation one-factor tests indicated that there were no statistically significant differences in $E$. coli concentrations between nonstorm and storm conditions 
(table 9; $F=1.020 ; p$-value=0.388). E. coli concentrations in stream water also were tested to determine whether the transect downstream from the bridge consistently had greater concentrations than the transect upstream from the bridge for all storms. Wilcoxon one-side signed rank results indicated that there was no statistically significant increase in E. coli concentrations downstream from the bridge at the SFEdisto bridge site during storms (table $10 ; Z=-0.135$; $p$-value $=0.596$ ).
One PAH compound, benzo[b]fluoranthene, was detected once $($ E $0.009 \mu \mathrm{g} / \mathrm{L})$ at the SFEdisto bridge site at the upstream transect during storm sampling at a level less than its LRL $(0.30 \mu \mathrm{g} / \mathrm{L}$; appendix table 3.4; Romanok and others, 2020). The detection occurred during the February 3 , 2016 , storm at a streamflow of $825 \mathrm{ft}^{3} / \mathrm{s}$, and no detectable concentrations were reported at the downstream transect. Concentration of the detected PAH was below its LRL by an order of magnitude.
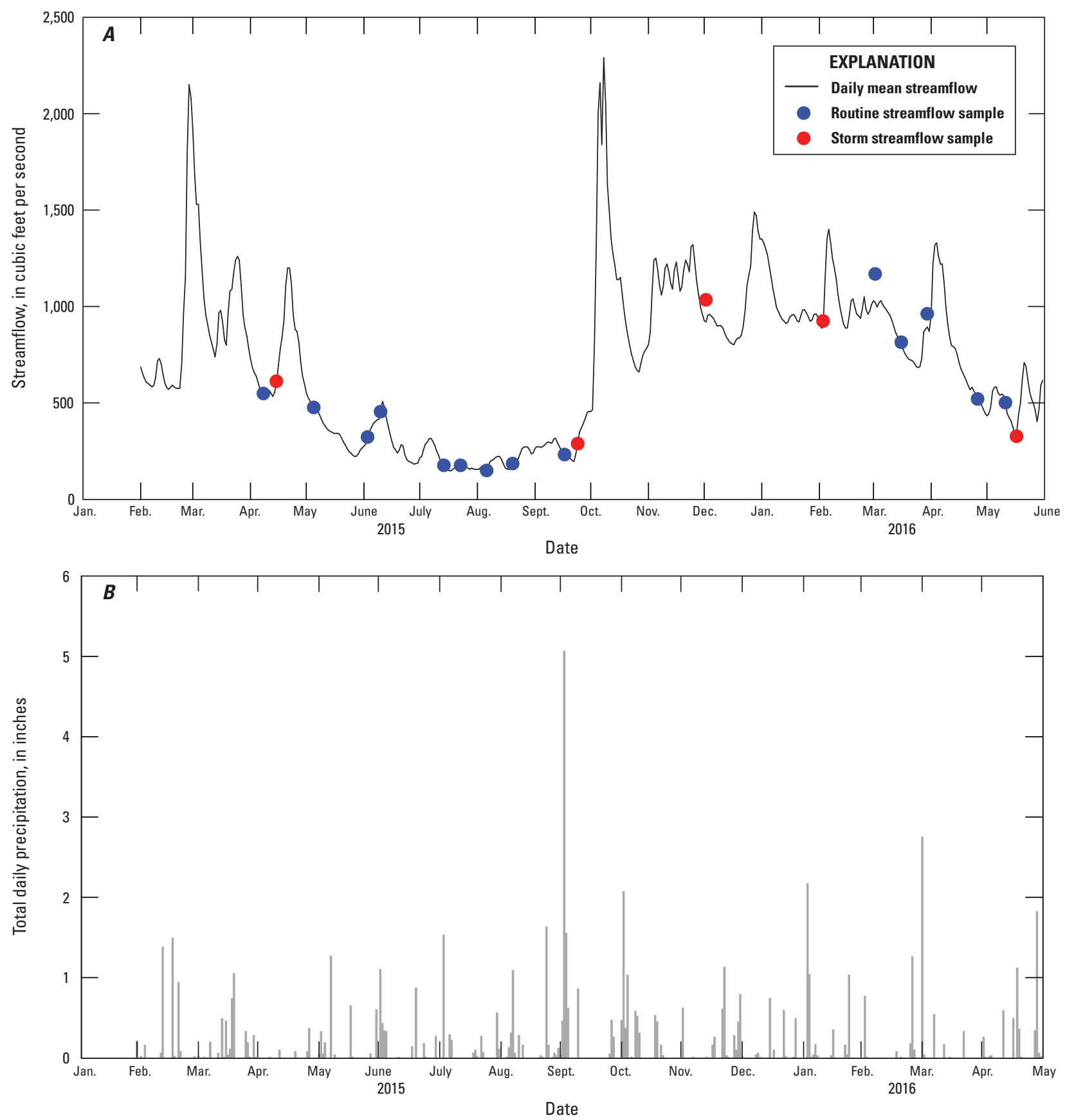

Figure 23. Graphs showing a time series of, $A$, daily mean streamflow and instantaneous streamflow during sampling and, $B$, total daily precipitation at the South Fork Edisto River near Denmark, South Carolina (U.S. Geological Survey station 02173000), January 2015 to June 2016. 

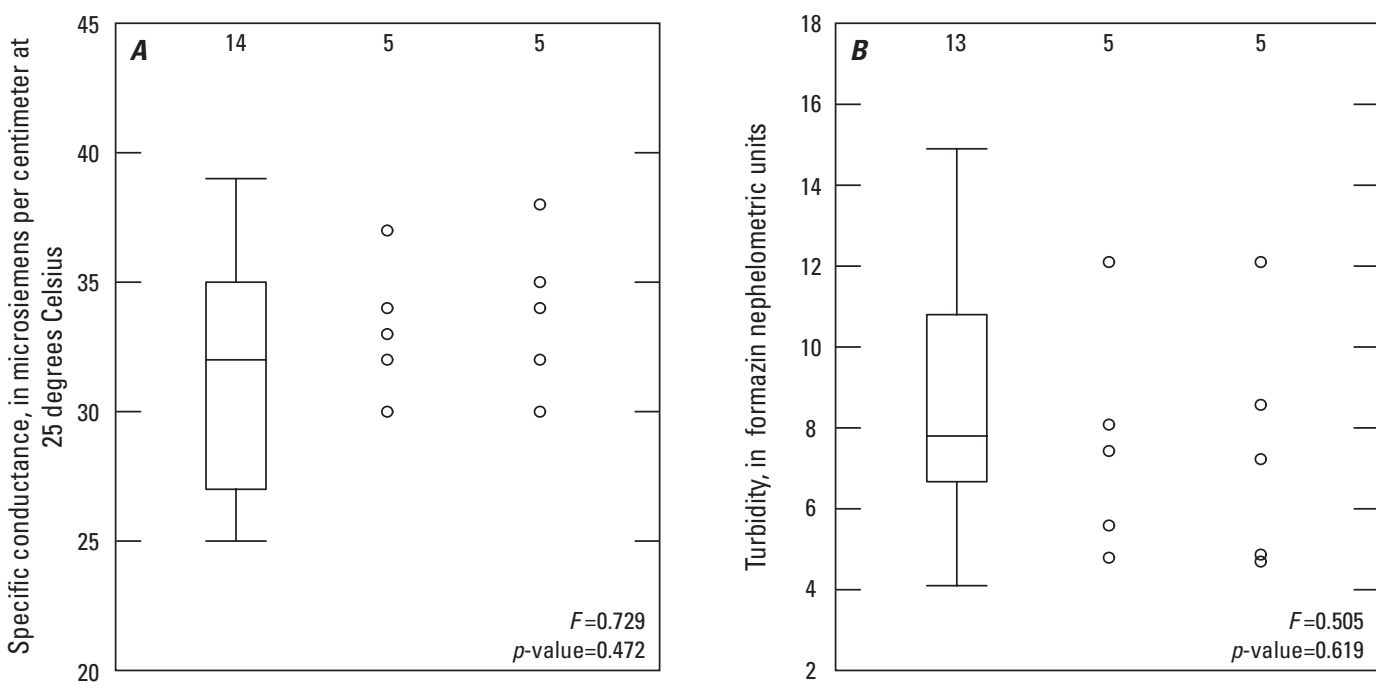

\section{Number of samples}

Maximum

75th percentile

Median

25th percentile

Minimum

Note: Small circles are shown instead of a boxplot if the

number of samples is five or less.

The number beside the circle

means that there is more than

one sample at that location.

$F$, Fstatistic

$p$-value, probability value

US, upstream
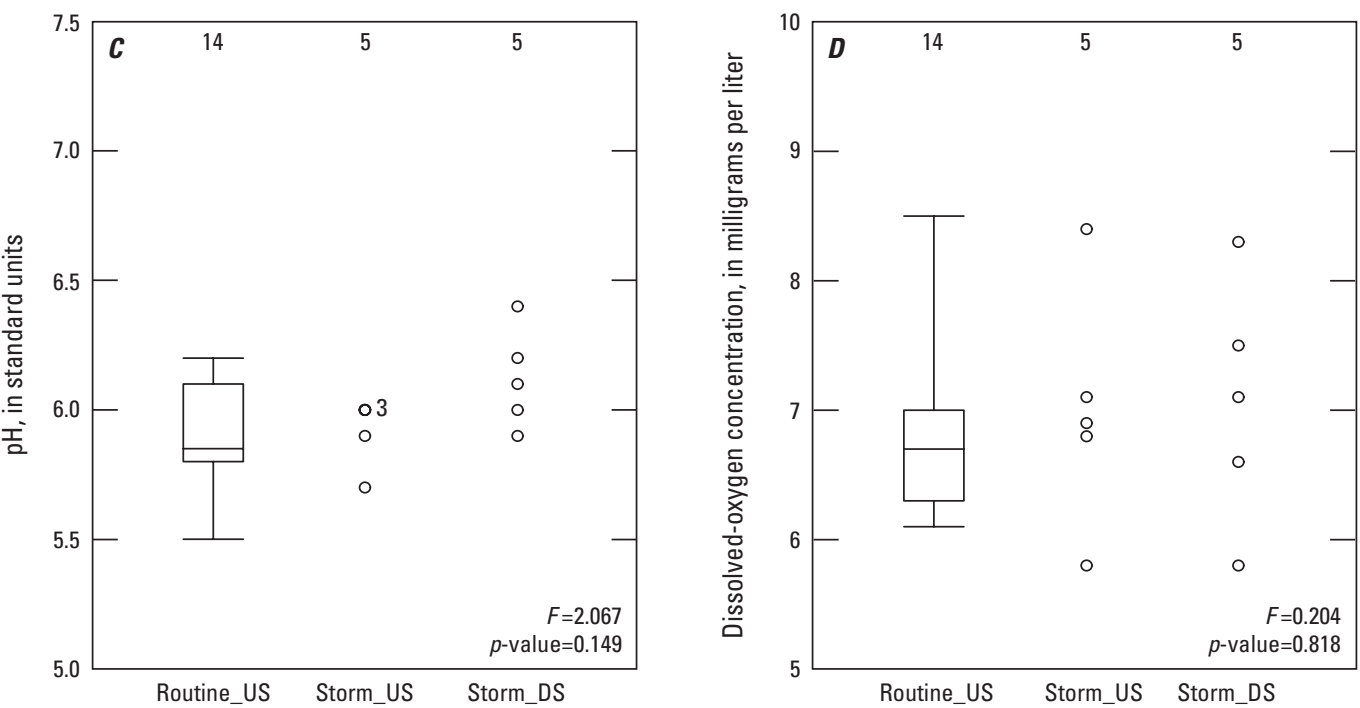

DS, downstream

Figure 24. Boxplots showing field properties in stream water at South Fork Edisto River near Denmark, South Carolina (U.S. Geological Survey station 02173000), measured at upstream and downstream transects during routine and storm conditions, April 2015 to May 2016. $A$, specific conductance. $B$, turbidity. $C, \mathrm{pH}$. $D$, dissolved oxygen. 

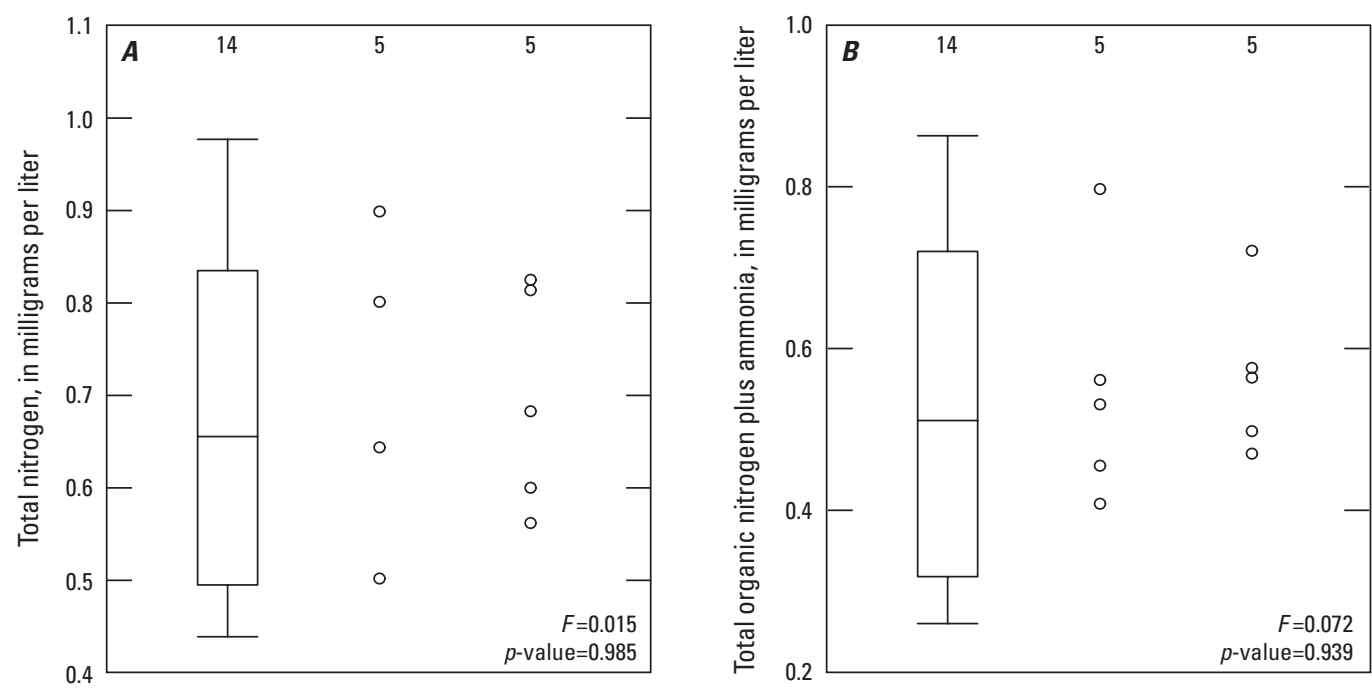

EXPLANATION
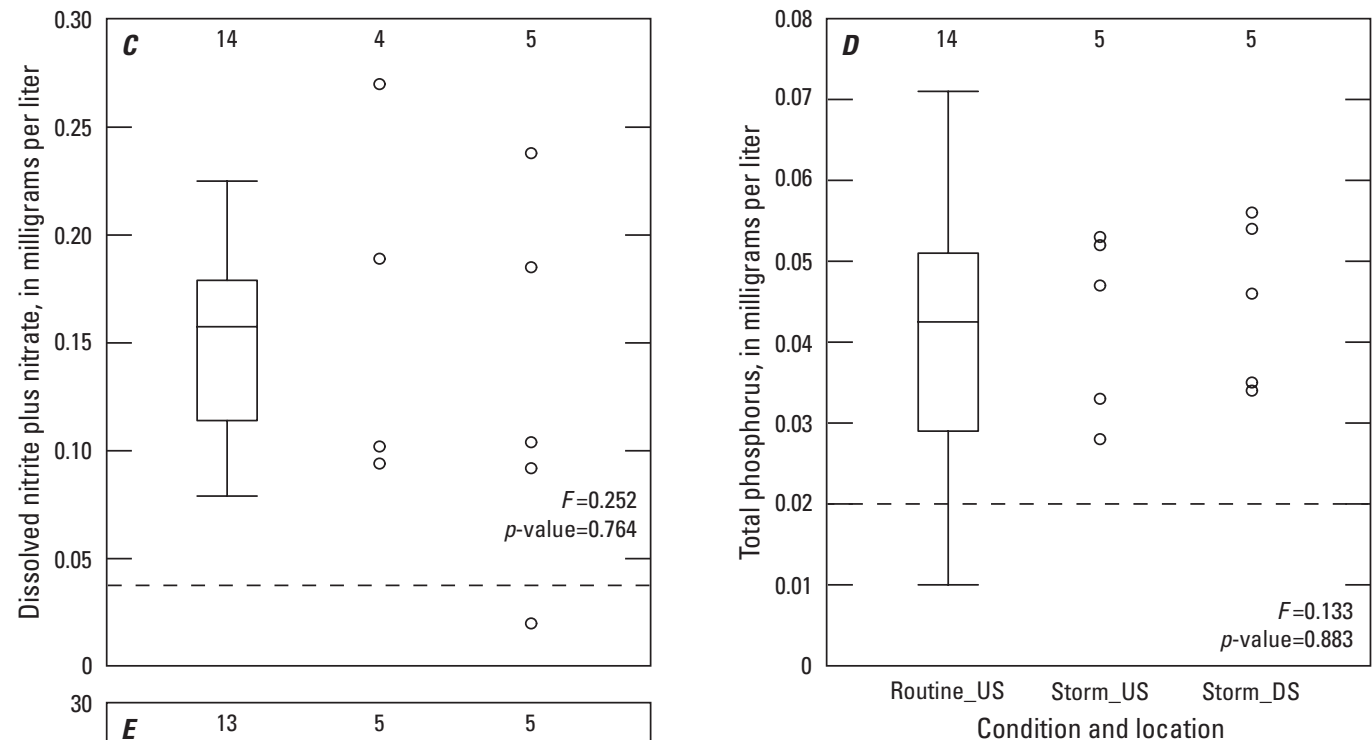

14 Number of samples

Maximum

75th percentile

Median

25th percentile

Minimum

Laboratory reporting level

Note: Small circles are shown

instead of a boxplot if the

number of samples is five or less.

The number beside the circle

means that there is more than

one sample at that location.

$F$, Fstatistic

$p$-value, probability value

US, upstream

DS, downstream

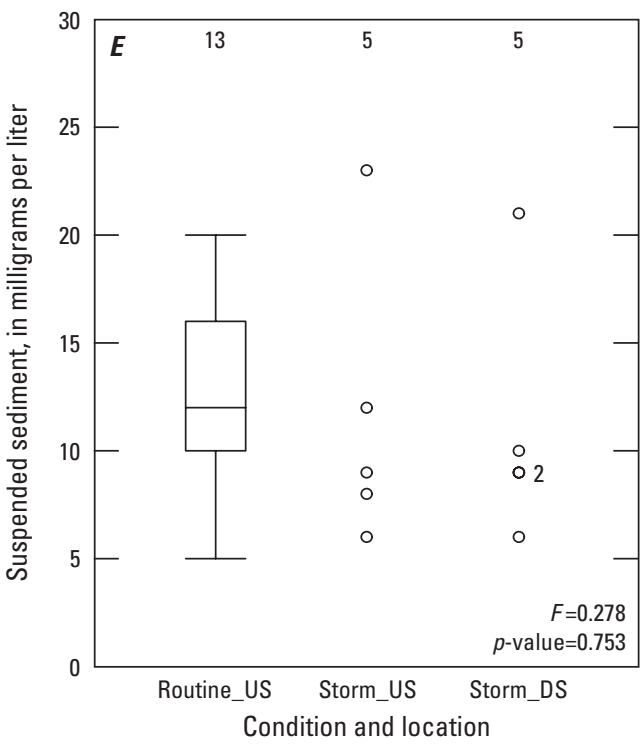

Figure 25. Boxplots showing nutrient and suspended-sediment concentrations in stream water at the South Fork Edisto River near Denmark, South Carolina (U.S. Geological Survey station 02173000), measured at upstream and downstream transects during routine and storm conditions, April 2015 to May 2016. A, total nitrogen. $B$, total organic nitrogen plus ammonia. $C$, dissolved nitrite plus nitrate. $D$, total phosphorus. $E$, suspended sediment. 

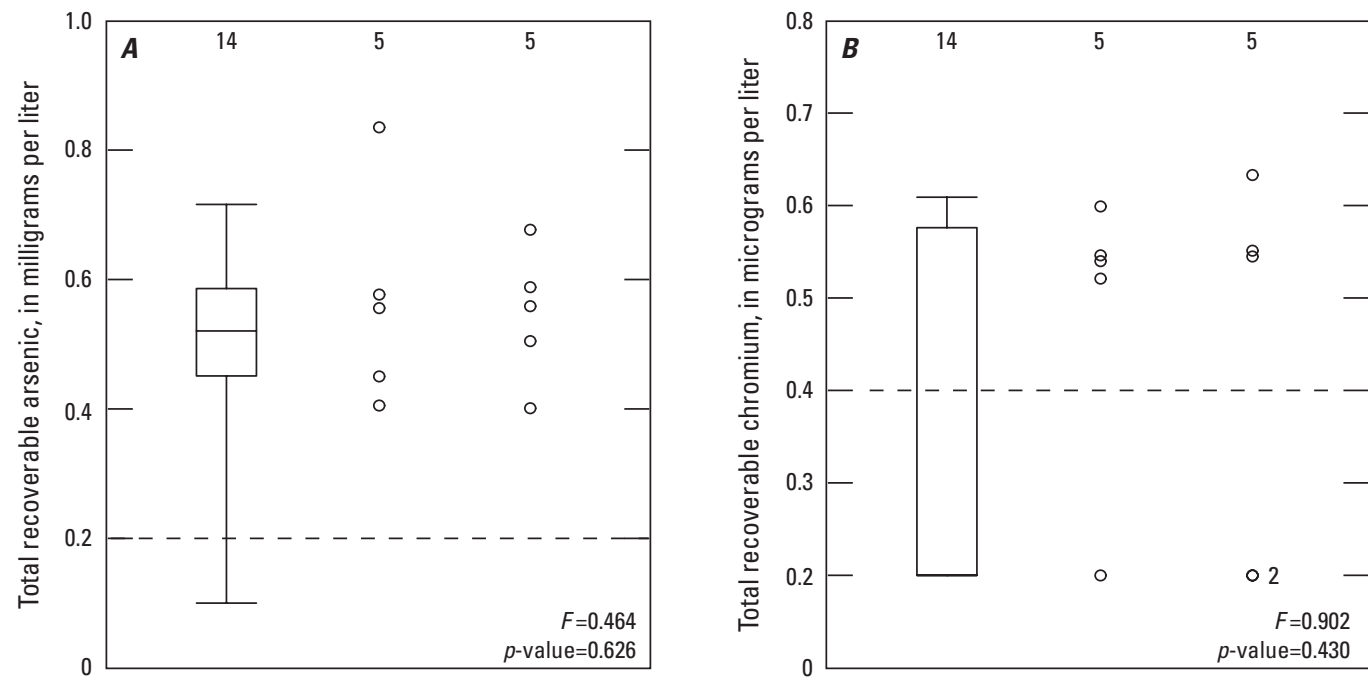

EXPLANATION

14 Number of samples

Maximum

75th percentile

Median

25th percentile

Minimum

Laboratory reporting level

South Carolina Department of Health and Environmental Control (SCDHEC) criterion continuous concentration of $0.54 \mu \mathrm{g} / \mathrm{L}$

Note: Small circles are shown instead of a boxplot if the number of samples is five or less. The number beside the circle means that there is more than one sample at that location. $F$, Fstatistic

$p$-value, probability value

US, upstream

DS, downstream
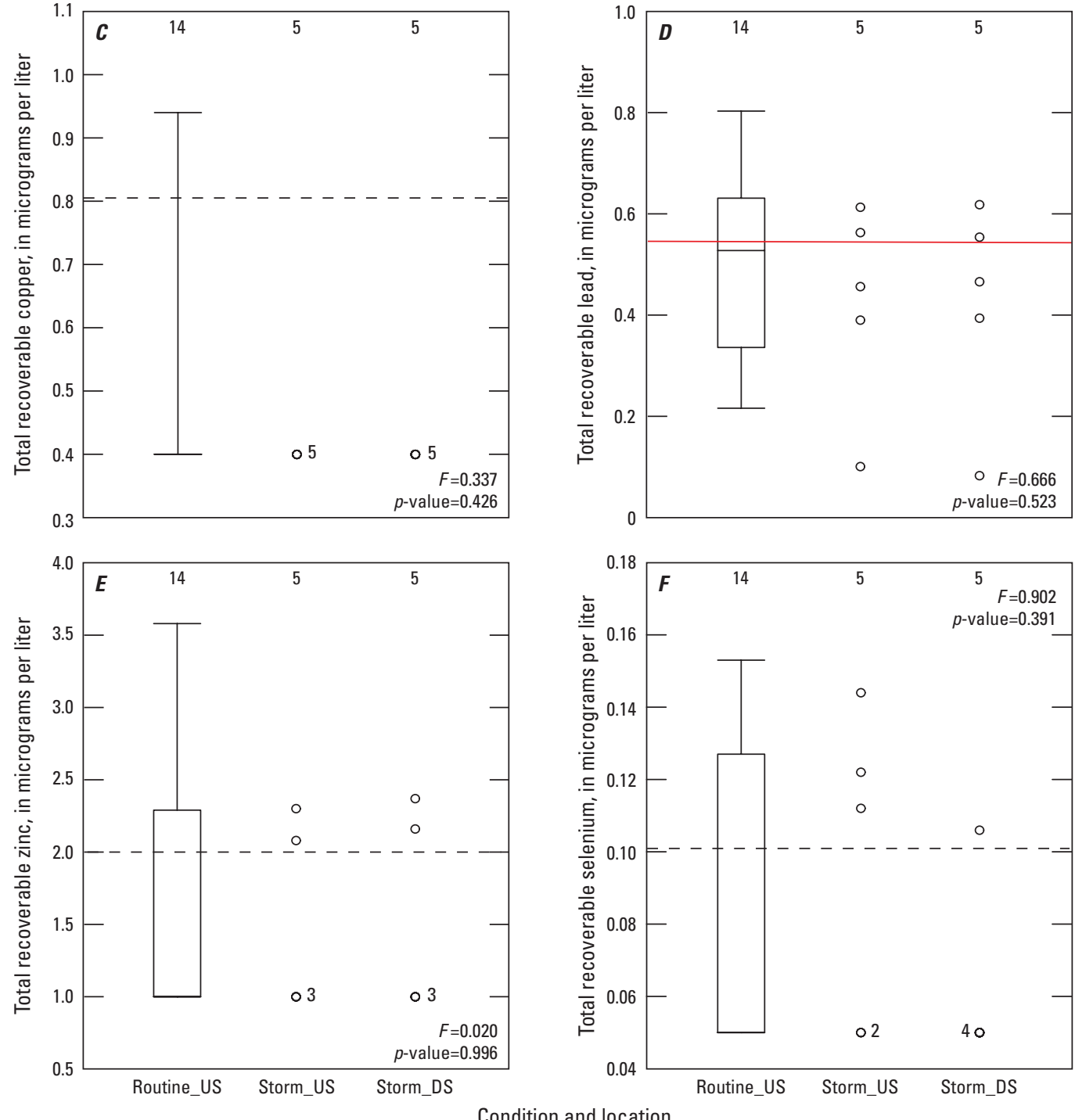

Condition and location

Figure 26. Boxplots of total recoverable trace-metal concentrations in stream water at the South Fork Edisto River near Denmark, South Carolina (U.S. Geological Survey station 02173000), measured at upstream and downstream transects during routine and storm conditions, April 2015 to May 2016. $A$, arsenic. B, chromium. $C$, copper. $D$, lead. E, zinc. F, selenium. 


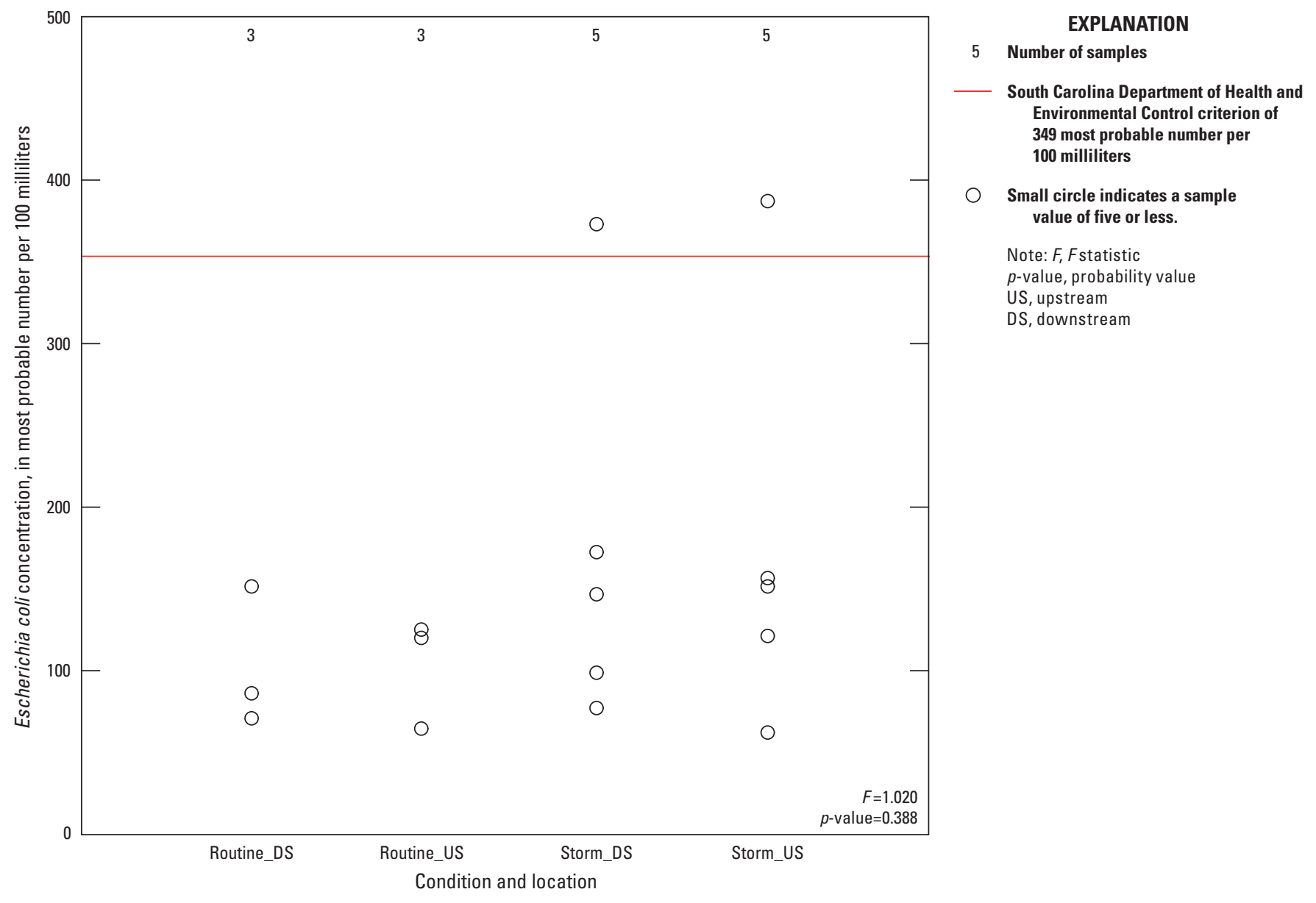

Figure 27. Boxplot showing Escherichia coli concentrations in stream water at South Fork Edisto River near Denmark, South Carolina (U.S. Geological Survey station 02173000), measured at upstream and downstream transects during routine and storm conditions, March 2015 to May 2016.

\section{Fishing Creek}

Fishing Creek near Rock Hill is in the Piedmont ecoregion in South Carolina. In total, 12 routine (nonstorm) and 10 storm samples were collected from Fishing Creek at the Fishing bridge site July 2016 to April 2018 (table 3; appendix table 3.5; Romanok and others, 2020). Streamflow varied from 0.26 to $5.8 \mathrm{ft}^{3} / \mathrm{s}$ at the time of storm sampling and from 0.03 to $11 \mathrm{ft}^{3} / \mathrm{s}$ at the time of routine sampling (table 2; appendix table 3.5; fig. 28A; Romanok and others, 2020). The sampled streamflow conditions covered the range of daily streamflow conditions of 0.01 to $2,9101 \mathrm{ft}^{3} / \mathrm{s}$ for the period of record at the Fishing bridge site (table 1). Precipitation at the Fishing bridge site was only in the form of rainfall during the period of study. Rainfall amounts of the sampled storms ranged from 0.02 to 1.19 in. with intensities that ranged from 0.05 to $1.29 \mathrm{in} / \mathrm{hr}$ (table 2; fig. 28B). Antecedent conditions ranged from less than 1 to 16 days since last rainfall. The mean potential bridge-deck runoff rate (bridge discharge) for each storm was estimated to range from 0.002 to $0.121 \mathrm{ft}^{3} / \mathrm{s}$, representing a ratio of bridge-deck runoff to streamflow of
0.16 to 43.3 percent at the time of sampling (table 2). In fact, in storms 1 and 4, these estimated bridge-runoff contributions of 4.3 and 43.3 percent, respectively, of streamflow suggested the potential for limited dilution of storm runoff entering the stream from the bridge. Storm 4 on October 23, 2017, probably represented the greatest potential of impact because it had been 7 days since last rainfall and Fishing Creek had extremely low-flow conditions $\left(0.28 \mathrm{ft}^{3} / \mathrm{s}\right)$ with high intensity rainfall (1.29 in/hr) and rainfall amounts (1.19 in.), indicating bridge-deck runoff represented 43.3 percent of streamflow (table 2). Of the storms sampled at this site, those conditions provided the least dilution capacity of the river with a good opportunity for accumulation of contaminants on the bridge deck before rainfall and a strong potential of wash-off of those contaminants during rainfall.

At the Fishing bridge site, a one-time sampling of the accumulated sediment on the bridge deck near the storm drainage systems (downspouts and vertical openings) was conducted in June 2016 during the start of water sampling (table 3). At the beginning of the water-sampling period, streambed sediment was sampled once (December 2016) and 
Hester-Dendy artificial substrates were deployed (October 2016) at transects downstream and upstream from the Fishing bridge site.

Specific conductance measurements made at the Fishing bridge site ranged from 85 to $155 \mu \mathrm{S} / \mathrm{cm}$ during the sampling period (appendix table 3.5; fig. 29A; Romanok and others, 2020). Turbidity levels were below the SCDHEC criterion of $50 \mathrm{NTU}$, ranging from 3.3 to $37.6 \mathrm{FNU}$ during storm and routine samplings (fig. 29B). At the Fishing bridge site, $\mathrm{pH}$ ranged from 6.5 to $7.3 \mathrm{SU}$ and had a median of $6.9 \mathrm{SU}$ (fig. 29C). DO concentrations ranged from 0.2 to $11.0 \mathrm{mg} / \mathrm{L}$ during the study period, periodically falling below the SCDHEC criterion of minimum DO above $4 \mathrm{mg} / \mathrm{L}$ in the summer months during periods of low streamflow conditions (less than $1 \mathrm{ft}^{3} / \mathrm{s}$; fig. 29D; table 4).

Permutation one-factor tests were run to compare the physical properties of $\mathrm{SC}, \mathrm{pH}, \mathrm{DO}$, and turbidity measurements among the routine, storm_US, and storm_DS samples. Permutation-derived $F$ statistics and $p$-values greater than 0.05 determined that the within-group variation was greater than the among-group variation for these water-quality data (table 9). These results indicated that bridge-deck runoff at the Fishing bridge site did not significantly alter $\mathrm{SC}, \mathrm{pH}, \mathrm{DO}$, and turbidity measurements in Fishing Creek at the downstream and upstream transects compared to the ambient conditions at the upstream transect at the Fishing bridge site (figs. 29A-D). The Wilcoxon one-sided signed rank test results also indicated that there were no statistically significant increases during storms downstream from the bridge in physical properties, except for turbidity $(Z=2.023$, $p$-value $=0.032$; table 10 ).

At the Fishing bridge site, TN concentrations ranged from 0.28 to $0.57 \mathrm{mg} / \mathrm{L}$ in all samples (appendix table 3.5 ; Romanok and others, 2020). Median TN concentrations of 0.42, 0.41 , and $0.51 \mathrm{mg} / \mathrm{L}$ in routine, storm_US, and storm_DS samples, respectively, demonstrated some variability with respect to the storm_DS samples (appendix table 3.5; fig. 30A). TN concentrations consisted of species of dissolved $\mathrm{NO}_{2}+\mathrm{NO}_{3}$ and TKN concentrations. Median TKN concentrations were 0.32 , 0.36 , and $0.44 \mathrm{mg} / \mathrm{L}$ in routine, storm_US, and storm_DS samples, respectively (appendix table 3.5; fig. 30B; Romanok and others, 2020), whereas median $\mathrm{NO}_{2}+\mathrm{NO}_{3}$ concentrations were much lower at $0.05,<0.04$, and $<0.04 \mathrm{mg} / \mathrm{L}$, respectively (fig. 30C). Additionally, the range of TN concentration was most like the TKN concentrations (as compared to $\mathrm{NO}_{2}+\mathrm{NO}_{3}$ ), suggesting that TN was predominantly composed of TKN.

Total phosphorus concentrations ranged from 0.026 to $0.142 \mathrm{mg} / \mathrm{L}$ in all samples (appendix table 3.5; Romanok and others, 2020) at the Fishing bridge site. Median TP concentrations were $0.053,0.054$, and $0.062 \mathrm{mg} / \mathrm{L}$ in routine, storm_US, and storm_DS samples, respectively (appendix table 3.5; fig. 30D; Romanok and others, 2020). SSCs were highly variable at this bridge site, ranging from 7 to $152 \mathrm{mg} / \mathrm{L}$, and median SSCs were 16,12 , and $22.5 \mathrm{mg} / \mathrm{L}$ in routine, storm_US, and storm_DS samples, respectively (appendix table 3.5; fig. 30E; Romanok and others, 2020). Overall, there were no observable change in range of nutrient or SSCs in storm_DS samples compared to the other sample groups.

Permutation one-factor tests were run on the nutrient and SSC data to compare concentrations among routine, storm_US, and storm_DS samples to determine if statistical differences were present. Resulting permutation-derived $F$ statistics (signal-to-noise ratio) were low and $p$-values were greater than 0.05 , indicating that the within-group variation was greater than the among-group variation for these waterquality data (table 9). These results indicated that bridge-deck runoff at the Fishing bridge site did not significantly alter nutrient and SSCs in Fishing Creek at the downstream and upstream transects compared to the ambient conditions at the upstream transect at the Fishing bridge site (figs. 30A-E). However, results of the Wilcoxon one-sided signed rank test indicated that there were statistically significant increases in $\mathrm{TN}$ and TKN concentrations downstream from the bridge at the Fishing bridge site during storms $(Z=2.023, p$-value $=0.030$ and $Z=2.023$, $p$-value $=0.032$, respectively; table 10 ).

Downstream increases in TN, TKN, and turbidity concentrations at the Fishing bridge site were further evaluated by Spearman $\rho$ correlation analysis among each other and rainfall characteristics at the site. Significantly positive correlations were identified between downstream changes in TN and TKN concentrations ( $\rho=0.999, p$-value $<0.001$; table 12). This finding was not surprising, because, as mentioned earlier, TN concentrations were composed predominantly of TKN species of nitrogen. Downstream increases in turbidity were significantly correlated with downstream increases in TN $(\rho=0.912, p$-value $=0.031)$ and TKN $(\rho=0.928, p$-value $=0.023)$ (table 12$)$, which may be explained by greater particulate nitrogen species within TKN being transported from the bridge during storms. However, downstream increases in TN, TKN, or turbidity were not significantly correlated to changes in rainfall amount, duration, intensity, or days since last rainfall (table 12).

As was identified at other bridge sites, detectable concentrations of trace metals were observed in stream water at the Fishing bridge site during routine and storm samplings (fig. $31 A-F$ ). Hardness at the Fishing bridge site had the greatest hardness when compared to the other bridge sites, ranging from 29.6 to $60.1 \mathrm{mg} / \mathrm{L}$ (appendix table 3.5; Romanok and others, 2020). The hardness-dependent SCDHEC CMC and CCC in table 4 were established for a hardness of $25 \mathrm{mg} / \mathrm{L}$ (increased hardness produces increased criterion levels; South Carolina Department of Health and Environmental Control, 2014c) but were compared to the trace-metal concentrations at this site as a conservative assessment. Even with the unadjusted $\mathrm{CMC}$ and $\mathrm{CCC}$, the total recoverable chromium, copper, zinc, arsenic, mercury, and selenium concentrations were consistently below the SCDHEC CMC and CCC for aquatic life established for Fishing River freshwater use (table 4; appendix table 3.5; figs. $31 A-F$ ). Total cadmium was detected once during a routine sample at a concentration of $0.29 \mu \mathrm{g} / \mathrm{L}$, which exceeds the $\mathrm{CCC}$ of $0.1 \mu \mathrm{g} / \mathrm{L}$ (Romanok and others, 2020). Copper 
and lead (total and filtered) were the most frequently detected metals, followed by arsenic, selenium, and chromium. Total recoverable lead concentrations periodically exceeded CCC criterion of $0.54 \mu \mathrm{g} / \mathrm{L}$. Specifically, CCC criterion for lead was exceeded in 2 of the 12 routine samples (upstream transect) and in 2 of the 5 storm samples ( 1 storm, downstream transect only; 1 storm, upstream and downstream transects; fig. 31D; Romanok and others, 2020).

Permutation one-factor tests statistics determined that the within-group variation was greater than the among-group variation for trace metal water-quality data (table 9). These results indicated that bridge-deck runoff at the Fishing bridge site did not significantly alter most of the trace-metal concentrations in Fishing Creek at the downstream and upstream transects compared to the ambient conditions at the upstream transect at the Fishing bridge site (figs. $31 A-F$ ). The exception was total zinc, which had greater concentrations during storms downstream than during routine sampling $(F=3.74 ; p$-value $=0.015)$. However, the Wilcoxon one-sided signed rank test results also indicated that there were no statistically significant increases in trace-metal concentrations during storms downstream from the bridge (table 10).

At the Fishing bridge site during the period of study, E. coli concentrations were frequently above the SCDHEC criterion of 349 MPN/100 mL in routine (2 out of 6 samples) and storm (8 out of 10 samples) samples with median E. coli concentrations of 224, 461, and $496 \mathrm{MPN} / 100 \mathrm{~mL}$ for routine, storm_US, and storm_DS samples, respectively (table 4; appendix table 3.5; Romanok and others, 2020). Composite samples (only) collected during routine, nonstorm conditions at upstream and downstream transects at the Fishing bridge site were compared to composite samples collected during storms at the same transects (fig. 32). Routine composite samples (upstream and downstream transects) had E. coli concentrations that ranged from 86 to $980 \mathrm{MPN} / 100 \mathrm{~mL}$, whereas storm samples ranged from 142 to $649 \mathrm{MPN} / 100 \mathrm{~mL}$ (upstream transect) and 96 to $866 \mathrm{MPN} / 100 \mathrm{~mL}$ (downstream transect; appendix table 3.5; Romanok and others, 2020). Although the range of concentrations for the storms seemed to be elevated relative to the routine conditions, permutation one-factor tests indicated that there were no statistically significant differences in $E$. coli concentrations between nonstorm and storm conditions (table 9; $F=0.072$; $p$-value $=0.931) . E$. coli concentrations in stream water also were tested to determine whether the transect downstream from the bridge consistently had greater concentrations than the transect upstream from the bridge for all storms. Results of the Wilcoxon test indicated that there was no statistically significant increase in E. coli concentrations downstream from the bridge at the Fishing bridge site during storms (table 10; $Z=0.405 ; p$-value $=0.396$ ).

The PAH compound, fluorene, was detected once and acenaphthene was detected twice at the Fishing bridge site at the upstream transect during routine sampling at levels an order of magnitude less than their LRLs $(0.34$ and $0.28 \mu \mathrm{g} / \mathrm{L}$, respectively; appendix table 3.5; Romanok and others, 2020). Concentrations during the routine samples with detectable PAHs were 0.004 and $0.015 \mu \mathrm{g} / \mathrm{L}$ during March 23, 2017, and February 21, 2018, routine samples, respectively. Detectable PAH concentrations were observed once in storm sampling during the October 23, 2017, storm at an extremely low streamflow of $0.28 \mathrm{ft}^{3} / \mathrm{s}$ at the downstream transect (Romanok and others, 2020). During this storm, five PAHs were detected at a $\sum \mathrm{PAH}_{17}$ concentration of $0.116 \mu \mathrm{g} / \mathrm{L}$ : acenaphthene $(0.031 \mu \mathrm{g} / \mathrm{L})$, benzo[b]fluoranthene $(0.03 \mu \mathrm{g} / \mathrm{L})$, benzo[ $k]$ fluoanthene $(0.01 \mu \mathrm{g} / \mathrm{L})$, naphthalene $(0.02 \mu \mathrm{g} / \mathrm{L})$, and pyrene $(0.025 \mu \mathrm{g} / \mathrm{L})$. 

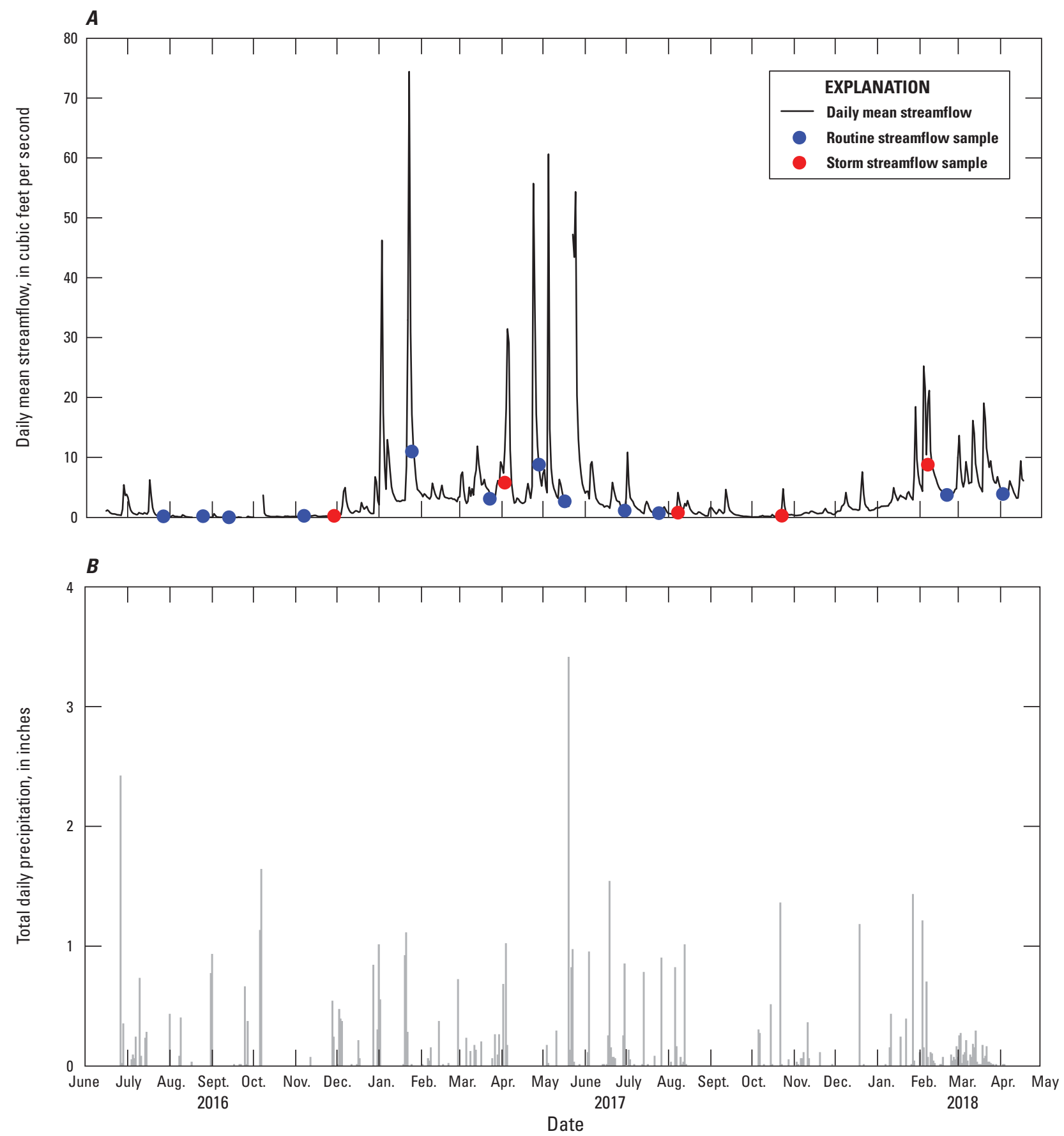

Figure 28. Graphs showing a time series of, $A$, daily mean streamflow and instantaneous streamflow during sampling and, $B$, total daily precipitation at Fishing Creek at Highway 5 below York, South Carolina (U.S. Geological Survey station 021473415), June 2016 to May 2018. 

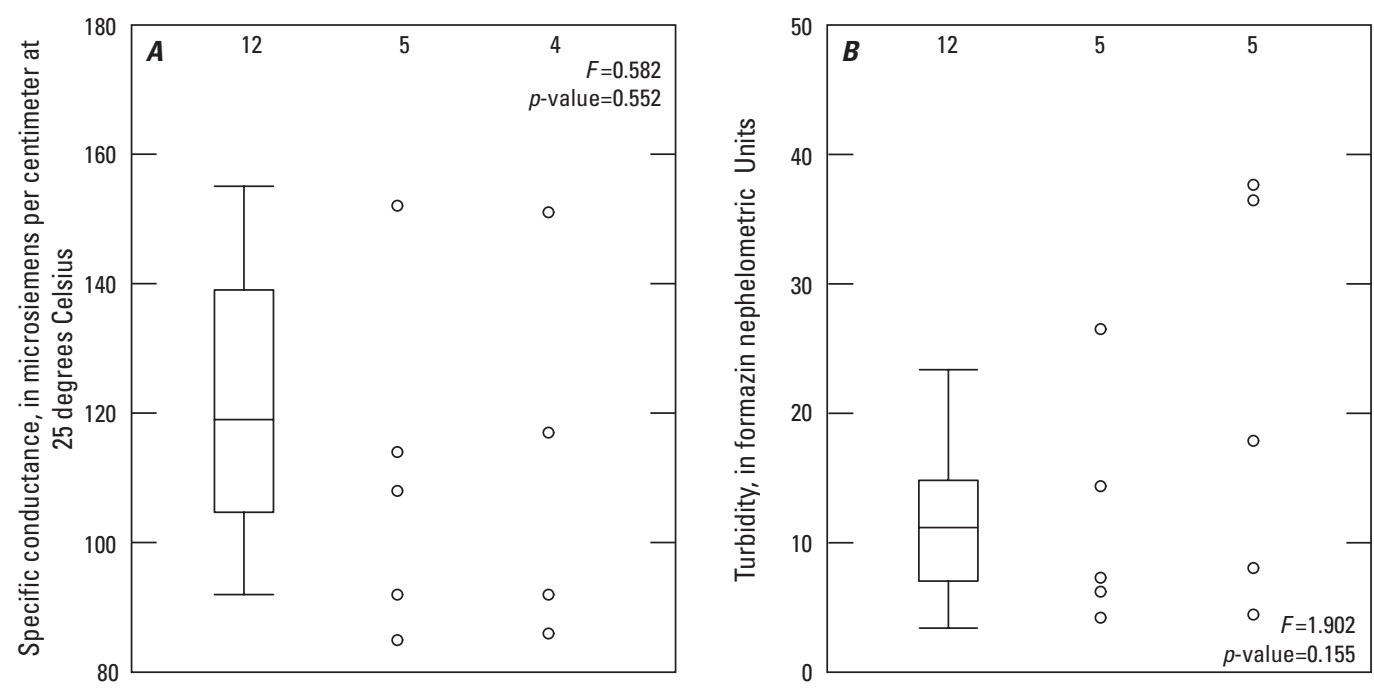

EXPLANATION
12 Number of samples
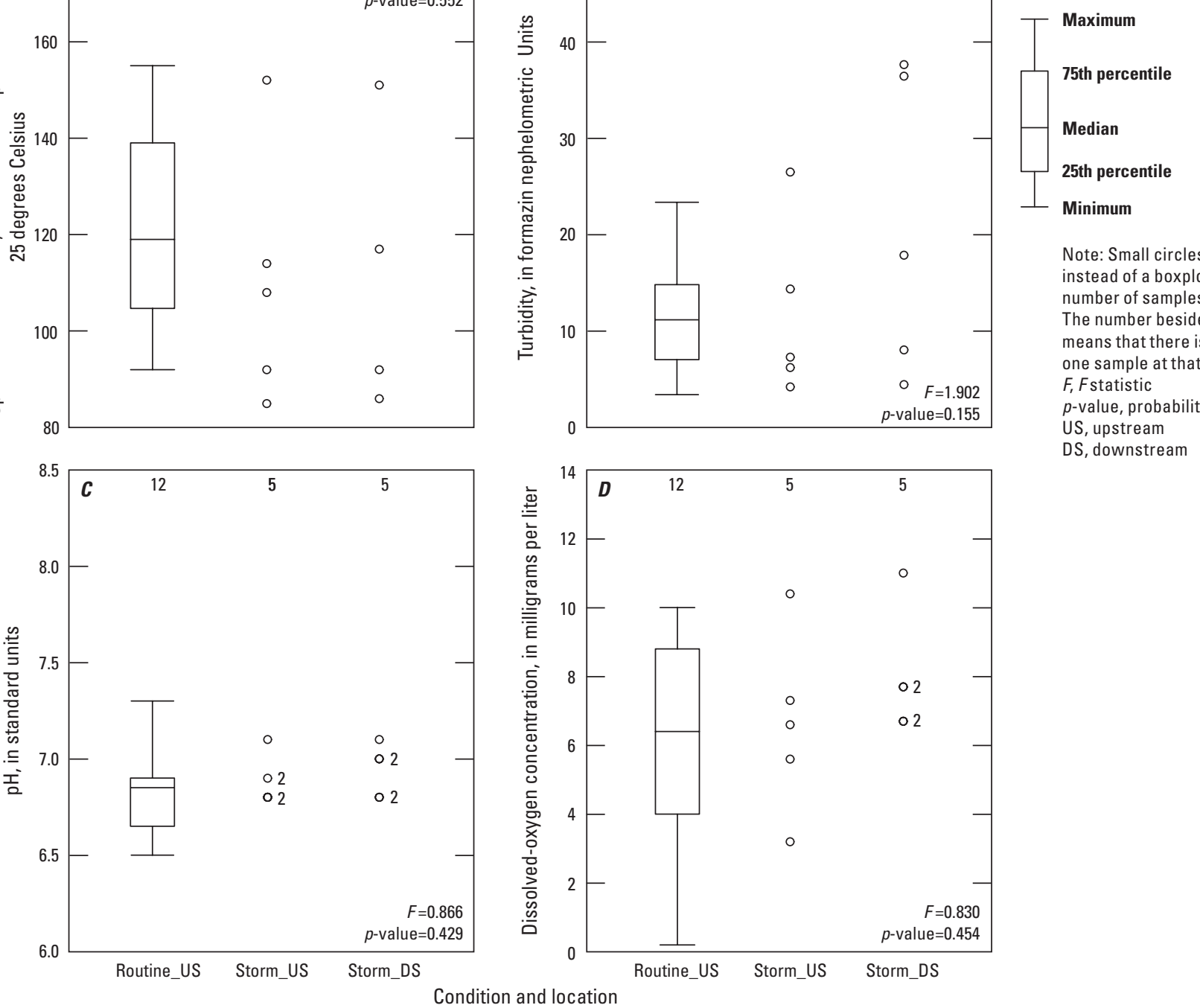

Note: Small circles are shown instead of a boxplot if the number of samples is five or less.

The number beside the circle means that there is more than one sample at that location.

F, Fstatistic

$p$-value, probability value

US, upstream

DS, downstream

Figure 29. Boxplots showing field properties in stream water at Fishing Creek at Highway 5 below York, South Carolina (U.S. Geological Survey station 021473415), measured at upstream and downstream transects during routine and storm conditions, July 2016 to April 2018. A, specific conductance. $B$, turbidity. $C$, pH. $D$, dissolved oxygen. 

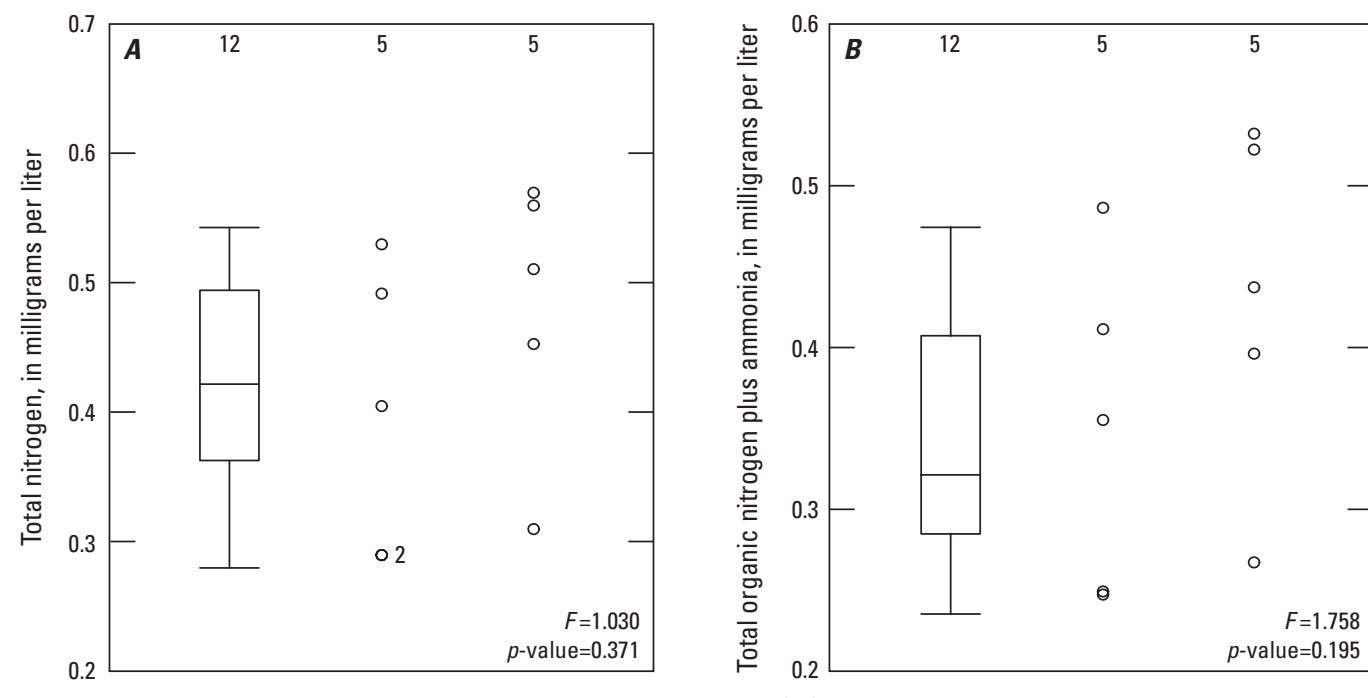

EXPLANATION

Number of samples

Maximum

75th percentile

Median

25th percentile

Minimum

Note: Small circles are shown instead of a boxplot if the number of samples is five or less.

The number beside the circle means that there is more than one sample at that location. $F$, Fstatistic $p$-value, probability value

S, upstream
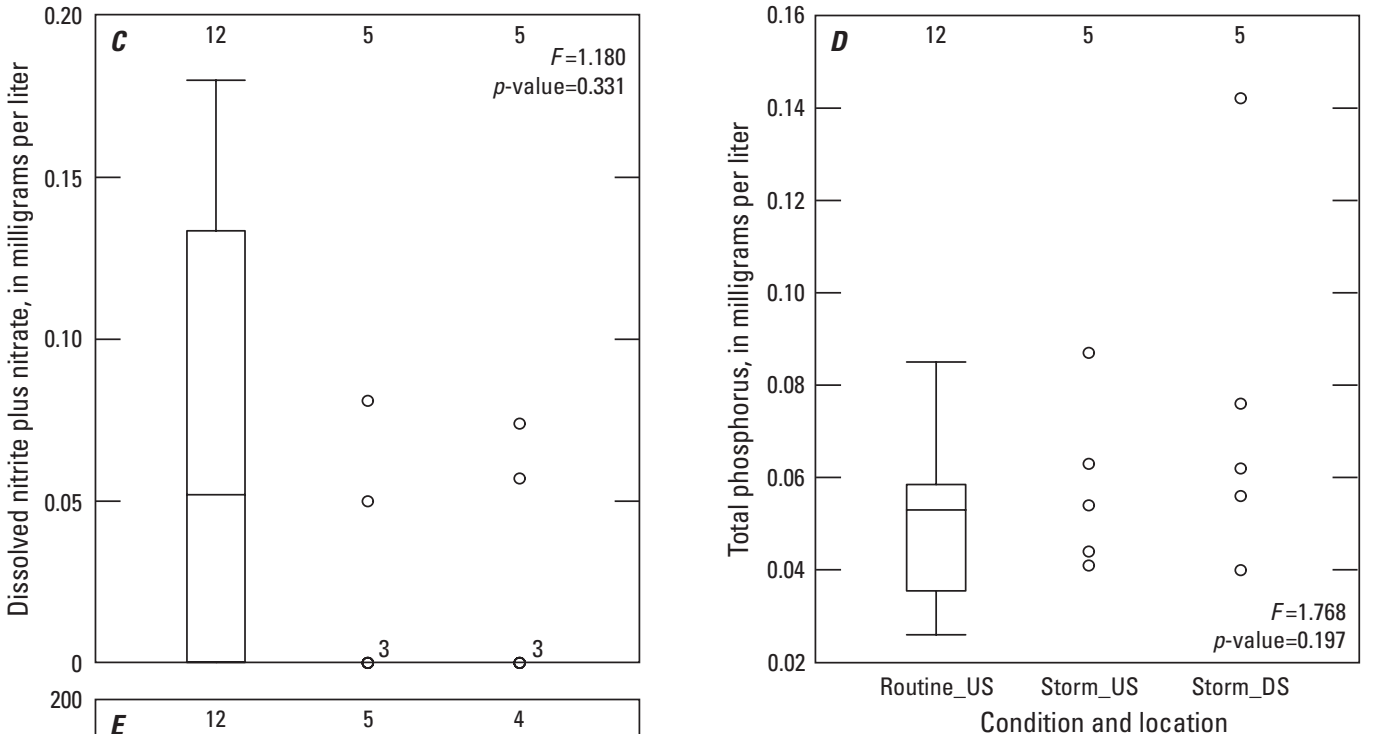

S, downstream

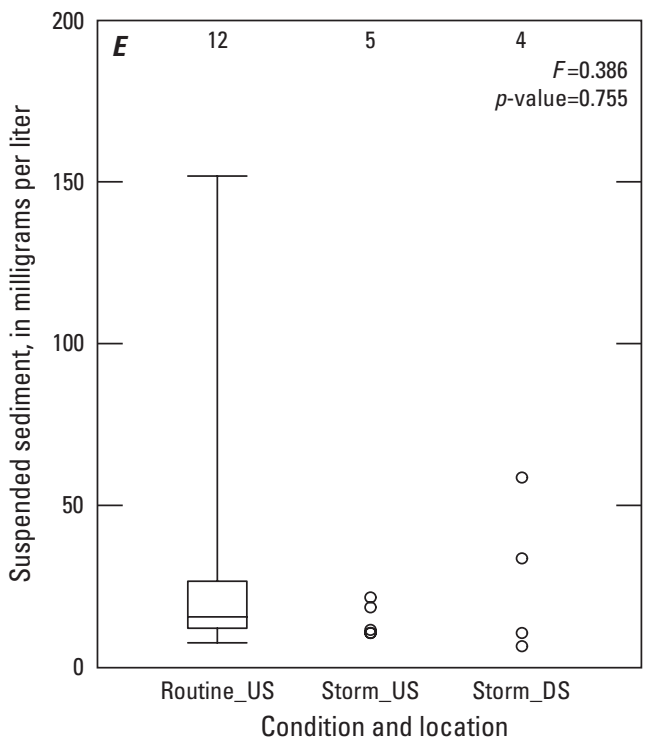

Figure 30. Boxplots showing nutrient and suspended-sediment concentrations in stream water at Fishing Creek at Highway 5 below York, South Carolina (U.S. Geological Survey station 021473415), measured at upstream and downstream transects during routine and storm conditions, July 2016 to April 2018. $A$, total nitrogen. $B$, total organic nitrogen plus ammonia. $C$, dissolved nitrite plus nitrate.

$D$, total phosphorus. $E$, suspended sediment. 
Table 12. Spearman rho correlation results for change in turbidity, total organic nitrogen plus ammonia, total nitrogen, and dissolved-oxygen

concentrations and rainfall characteristics at transects upstream and downstream from the bridge at Fishing Creek at Highway 5 near York,

South Carolina (U.S. Geological Survey station 021473415), for five storms from 2016 to 2017.

[Bold, italicized values represent statistically significant correlations $(\alpha=0.05)$; NA, not applicable; Grey-shaded cells are the main diagonal of the correlation matrix, which represent the variable correlated perfectly with itself]

\begin{tabular}{|c|c|c|c|c|c|c|c|c|}
\hline Variables used in correlation & $\begin{array}{l}\text { Downstream } \\
\text { change in } \\
\text { dissolved } \\
\text { oxygen }\end{array}$ & $\begin{array}{l}\text { Downstream } \\
\text { change in } \\
\text { turbidity }\end{array}$ & $\begin{array}{l}\text { Downstream } \\
\text { change in } \\
\text { total organic } \\
\text { nitrogen plus } \\
\text { ammonia }\end{array}$ & $\begin{array}{l}\text { Downstream } \\
\text { change } \\
\text { in total } \\
\text { nitrogen }\end{array}$ & $\begin{array}{l}\text { Rainfall } \\
\text { amount }\end{array}$ & $\begin{array}{l}\text { Rainfall } \\
\text { duration }\end{array}$ & $\begin{array}{l}\text { Rainfall } \\
\text { intensity }\end{array}$ & $\begin{array}{c}\text { Days } \\
\text { since last } \\
\text { rainfall }\end{array}$ \\
\hline \multicolumn{9}{|c|}{ Spearman's rho correlation coefficient } \\
\hline Downstream change in dissolved oxygen & 1.000 & 0.907 & 0.954 & 0.956 & -0.423 & -0.334 & -0.544 & 0.084 \\
\hline Downstream change in turbidity & 0.907 & 1.000 & 0.928 & 0.912 & -0.299 & -0.398 & -0.451 & 0.435 \\
\hline $\begin{array}{l}\text { Downstream change in total organic } \\
\text { nitrogen plus ammonia }\end{array}$ & 0.954 & 0.928 & 1.000 & 0.999 & -0.217 & -0.212 & -0.329 & 0.082 \\
\hline Downstream change in total nitrogen & 0.956 & 0.912 & 0.999 & 1.000 & -0.239 & -0.172 & -0.342 & 0.035 \\
\hline Rainfall amount & -0.423 & -0.299 & -0.217 & -0.239 & 1.000 & -0.058 & 0.974 & -0.031 \\
\hline Rainfall duration & -0.334 & -0.398 & -0.212 & -0.172 & -0.058 & 1.000 & 0.154 & -0.616 \\
\hline Rainfall intensity & -0.544 & -0.451 & -0.329 & -0.342 & 0.974 & 0.154 & 1.000 & -0.188 \\
\hline Days since last rainfall & 0.084 & 0.435 & 0.082 & 0.035 & -0.031 & -0.616 & -0.188 & 1.000 \\
\hline \multicolumn{9}{|c|}{ Probability values } \\
\hline Downstream change in dissolved oxygen & NA & 0.033 & 0.012 & 0.011 & 0.478 & 0.583 & 0.344 & 0.894 \\
\hline Downstream change in turbidity & 0.033 & NA & 0.023 & 0.031 & 0.625 & 0.507 & 0.446 & 0.464 \\
\hline $\begin{array}{l}\text { Downstream change in total organic } \\
\text { nitrogen plus ammonia }\end{array}$ & 0.012 & 0.023 & NA & 0 & 0.726 & 0.732 & 0.588 & 0.896 \\
\hline Downstream change in total nitrogen & 0.011 & 0.031 & 0 & NA & 0.698 & 0.782 & 0.573 & 0.956 \\
\hline Rainfall amount & 0.478 & 0.625 & 0.726 & 0.698 & NA & 0.927 & 0.005 & 0.961 \\
\hline Rainfall duration & 0.583 & 0.507 & 0.732 & 0.782 & 0.927 & NA & 0.805 & 0.268 \\
\hline Rainfall intensity & 0.344 & 0.446 & 0.588 & 0.573 & 0.005 & 0.805 & NA & 0.763 \\
\hline Days since last rainfall & 0.894 & 0.464 & 0.896 & 0.956 & 0.961 & 0.268 & 0.763 & NA \\
\hline
\end{tabular}



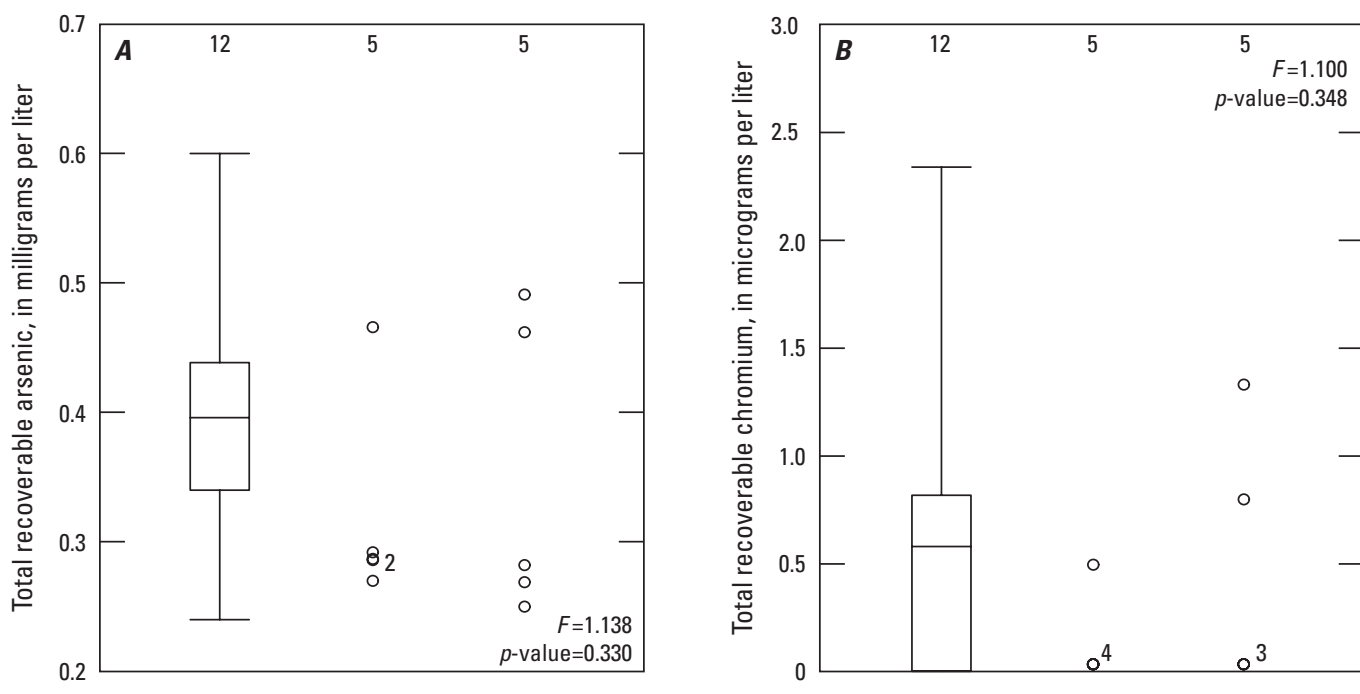

EXPLANATION

Number of samples

Maximum

75th percentile

Median

25th percentile

Minimum

South Carolina Department of Health and Environmental Control (SCDHEC) criterion continuous concentration

Note: Small circles are shown instead of a boxplot if the number of samples is five or less.

The number beside the circle means that there is more than one sample at that location.
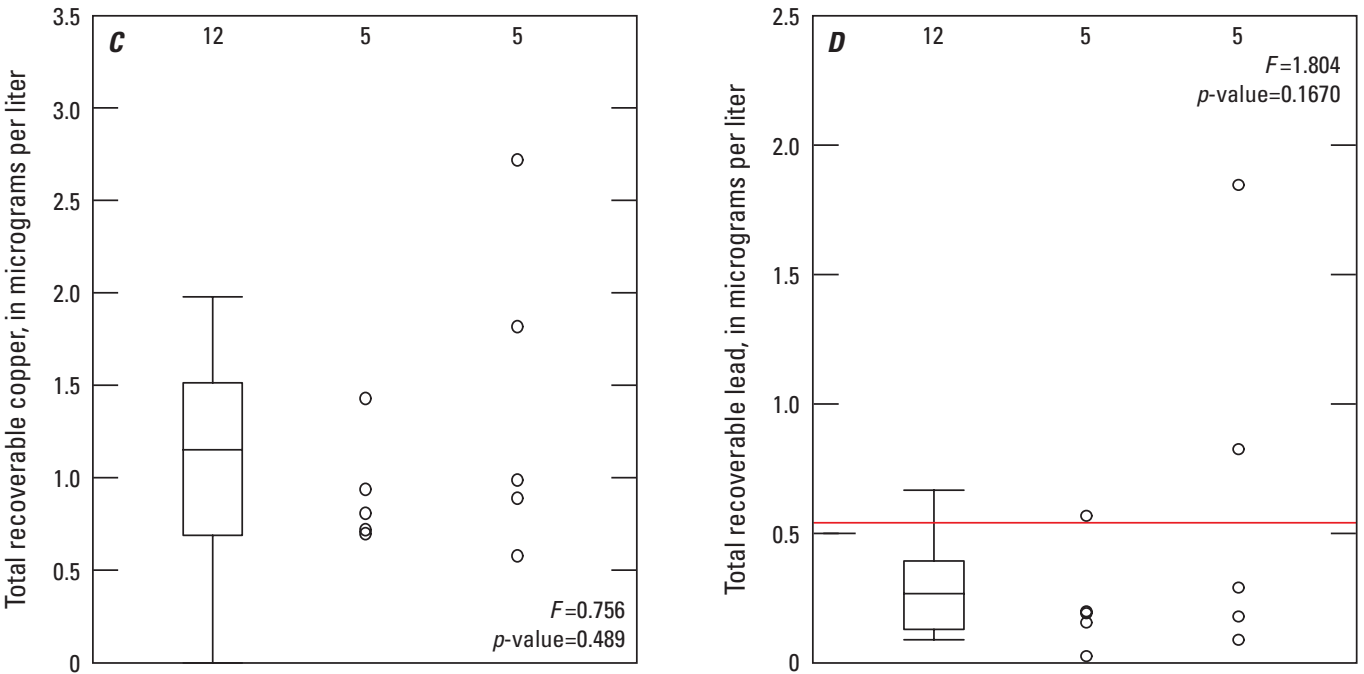

$F, F$ statistic

$p$-value, probability value

S, upstream

DS, downstream

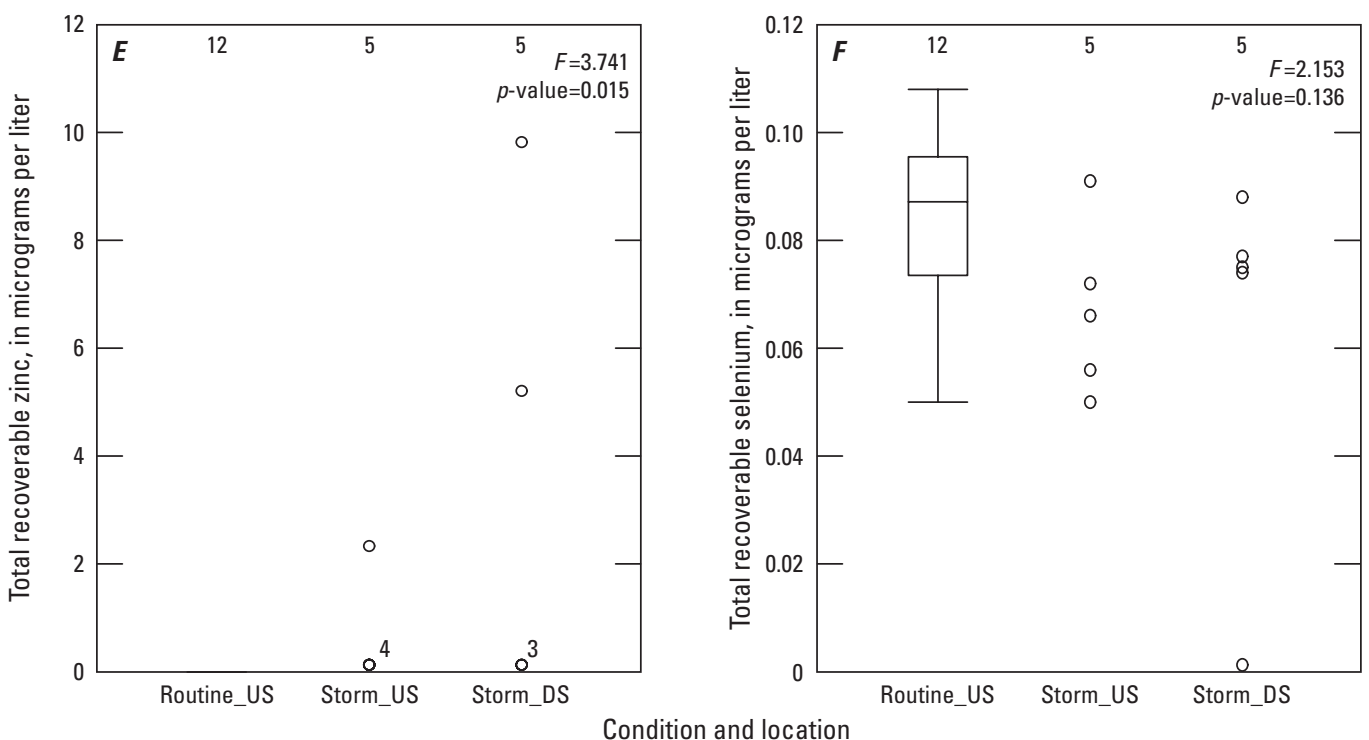

Figure 31. Boxplots showing total recoverable trace-metal concentrations in stream water at Fishing Creek at Highway 5 below York, South Carolina (U.S. Geological Survey station 021473415), measured at upstream and downstream transects during routine and storm conditions July 2016 to April 2018. A, arsenic. $B$, chromium. C, copper. $D$, lead. $E$, zinc. F, selenium. 


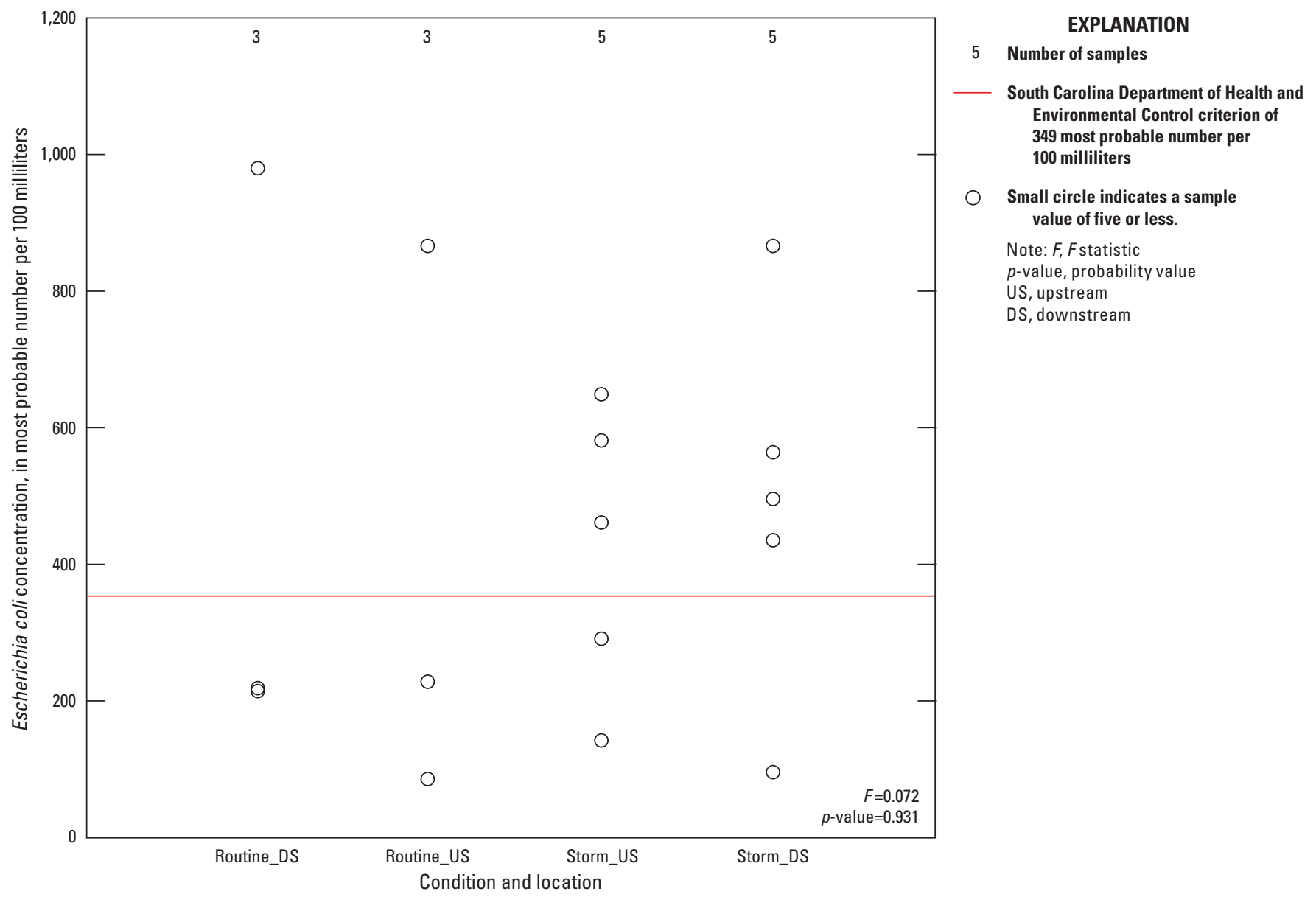

Figure 32. Boxplot showing Escherichia coli concentrations in stream water at Fishing Creek at Highway 5 below York, South Carolina (U.S. Geological Survey station 021473415), measured at upstream and downstream transects during routine and storm conditions, July 2016 to April 2018.

\section{Summary of Bridge Site Water Quality}

In summary, stream water samples collected during storms at transects upstream and downstream from the five bridge sites varied little in water quality when compared to ambient, routine conditions during the period of study (fig. 33A; table 9). Exceptions included lower chloride and zinc concentrations during storms at transects upstream and downstream from the NFEdisto and Turkey bridge sites than during routine conditions and greater number of
PAH detections during storms at the downstream transect at the Fishing bridge site than during routine conditions. Additionally, comparison of water quality at transects upstream and downstream from the five bridge sites during storms, indicated that only the Fishing bridge site had significantly greater turbidity, TN, and TKN concentrations downstream from the bridge (fig. 33B; table 10). The Turkey bridge site had greater total chromium concentrations, and the NFEdisto bridge site had greater $E$. coli concentrations at the transect downstream from the bridge site. 
A. Permutation matrix

\begin{tabular}{|c|c|c|c|c|c|c|}
\hline Bridge sites & Nutrients & Majors & $\begin{array}{c}\text { Field } \\
\text { parameters }\end{array}$ & Metals & $\begin{array}{l}\text { Polycyclic } \\
\text { aromatic } \\
\text { hydrocarbon }\end{array}$ & $\begin{array}{c}\text { Escherichia } \\
\text { coli }\end{array}$ \\
\hline $\begin{array}{l}\text { Lynches } \\
\text { River }\end{array}$ & $\begin{array}{c}\text { No } \\
\text { difference }\end{array}$ & $\begin{array}{c}\text { No } \\
\text { difference }\end{array}$ & $\begin{array}{c}\text { No } \\
\text { difference }\end{array}$ & $\begin{array}{c}\text { No } \\
\text { difference }\end{array}$ & $\begin{array}{c}\text { No } \\
\text { difference }\end{array}$ & $\begin{array}{c}\text { No } \\
\text { difference }\end{array}$ \\
\hline $\begin{array}{l}\text { NFEdisto } \\
\text { River }\end{array}$ & $\begin{array}{c}\text { No } \\
\text { difference }\end{array}$ & $\begin{array}{l}>\text { Chloride } \\
\text { during } \\
\text { Storm_US, } \\
\text { Storm_DS }\end{array}$ & $\begin{array}{c}\text { No } \\
\text { difference }\end{array}$ & $\begin{array}{c}\text { No } \\
\text { difference }\end{array}$ & $\begin{array}{c}\text { No } \\
\text { difference }\end{array}$ & $\begin{array}{c}\text { No } \\
\text { difference }\end{array}$ \\
\hline $\begin{array}{l}\text { SFEdisto } \\
\text { River }\end{array}$ & $\begin{array}{c}\text { No } \\
\text { difference }\end{array}$ & $\begin{array}{c}\text { No } \\
\text { difference }\end{array}$ & $\begin{array}{c}\text { No } \\
\text { difference }\end{array}$ & $\begin{array}{c}\text { No } \\
\text { difference }\end{array}$ & $\begin{array}{c}\text { No } \\
\text { difference }\end{array}$ & $\begin{array}{c}\text { No } \\
\text { difference }\end{array}$ \\
\hline $\begin{array}{l}\text { Turkey } \\
\text { Creek }\end{array}$ & $\begin{array}{c}\text { No } \\
\text { difference }\end{array}$ & $\begin{array}{c}\text { No } \\
\text { difference }\end{array}$ & $\begin{array}{c}\text { No } \\
\text { difference }\end{array}$ & $\begin{array}{l}>\text { Zinc (f), } \\
\text { selenium (f) } \\
\text { during } \\
\text { routine }\end{array}$ & $\begin{array}{c}\text { No } \\
\text { difference }\end{array}$ & $\begin{array}{c}\text { No } \\
\text { difference }\end{array}$ \\
\hline $\begin{array}{l}\text { Fishing } \\
\text { Creek }\end{array}$ & $\begin{array}{c}\text { No } \\
\text { difference }\end{array}$ & $\begin{array}{c}\text { No } \\
\text { difference }\end{array}$ & $\begin{array}{c}\text { No } \\
\text { difference }\end{array}$ & $\begin{array}{l}\text { Total } \\
\text { zinc }\end{array}$ & $\begin{array}{l}\text { >Detections } \\
\text { during } \\
\text { Storm_US, } \\
\text { Storm_DS }\end{array}$ & $\begin{array}{c}\text { No } \\
\text { difference }\end{array}$ \\
\hline
\end{tabular}

\section{B. Signed rank matrix}

\begin{tabular}{|c|c|c|c|c|c|c|}
\hline Bridge sites & Nutrients & Majors & $\begin{array}{c}\text { Field } \\
\text { parameters }\end{array}$ & Metals & $\begin{array}{c}\text { aromatic } \\
\text { hydrocarbon }\end{array}$ & $\begin{array}{c}\text { Escherichia } \\
\text { coli }\end{array}$ \\
\hline $\begin{array}{l}\text { Lynches } \\
\text { River }\end{array}$ & $\begin{array}{c}\text { No } \\
\text { difference }\end{array}$ & $\begin{array}{c}\text { No } \\
\text { difference }\end{array}$ & $\begin{array}{c}\text { No } \\
\text { difference }\end{array}$ & $\begin{array}{c}\text { No } \\
\text { difference }\end{array}$ & $\begin{array}{c}\text { No } \\
\text { difference }\end{array}$ & $\begin{array}{c}\text { No } \\
\text { difference }\end{array}$ \\
\hline $\begin{array}{l}\text { NFEdisto } \\
\text { River }\end{array}$ & $\begin{array}{c}\text { No } \\
\text { difference }\end{array}$ & $\begin{array}{c}\text { No } \\
\text { difference }\end{array}$ & $\mathrm{pH}$ & $\begin{array}{c}\text { No } \\
\text { difference }\end{array}$ & $\begin{array}{c}\text { No } \\
\text { difference }\end{array}$ & E. coli \\
\hline $\begin{array}{l}\text { SFEdisto } \\
\text { River }\end{array}$ & $\begin{array}{c}\text { No } \\
\text { difference }\end{array}$ & $\begin{array}{c}\text { No } \\
\text { difference }\end{array}$ & $\begin{array}{c}\text { No } \\
\text { difference }\end{array}$ & $\begin{array}{c}\text { No } \\
\text { difference }\end{array}$ & $\begin{array}{c}\text { No } \\
\text { difference }\end{array}$ & $\begin{array}{c}\text { No } \\
\text { difference }\end{array}$ \\
\hline $\begin{array}{l}\text { Turkey } \\
\text { Creek }\end{array}$ & $\begin{array}{c}\text { No } \\
\text { difference }\end{array}$ & $\begin{array}{c}\text { No } \\
\text { difference }\end{array}$ & $\begin{array}{c}\text { No } \\
\text { difference }\end{array}$ & $\begin{array}{c}\text { Total } \\
\text { chromium }\end{array}$ & $\begin{array}{c}\text { No } \\
\text { difference }\end{array}$ & $\begin{array}{c}\text { No } \\
\text { difference }\end{array}$ \\
\hline $\begin{array}{l}\text { Fishing } \\
\text { Creek }\end{array}$ & TN, TKN & $\begin{array}{c}\text { No } \\
\text { difference }\end{array}$ & Turbidity & $\begin{array}{c}\text { No } \\
\text { difference }\end{array}$ & $\begin{array}{c}\text { No } \\
\text { difference }\end{array}$ & $\begin{array}{c}\text { No } \\
\text { difference }\end{array}$ \\
\hline
\end{tabular}

Note: US, upstream; DS, downstream; E. coli, Escherichia coli; TN, total nitrogen; TKN, total Kjeldahl nitrogen See table 1 for information about the bridge sites.

Figure 33. Matrices showing the results of, $A$, the permutation one-factor test and pairwise Wilcoxon test that determined if statistically significant differences in stream water concentrations for routine and storm samples and, B, the paired one-sided Wilcoxon signed rank test to determine if storm sample constituent concentrations at the downstream transect were greater than at the upstream transect at the five selected bridge sites, South Carolina, 2013 to 2018. 


\section{Sediment Quality}

As mentioned earlier, sediment and debris accumulate on bridge decks from atmospheric and vehicular sources, in turn, producing a potential source of contaminants to the stream during periods of storm runoff. At each bridge site immediately before water sampling, a one-time composite of bridge-deck sediment was collected and analyzed for metal and PAH concentrations. Because only one sample was collected, statistical tests were not performed to evaluate differences between upstream and downstream transects. Instead, metal and PAH concentrations were compared to existing threshold effect concentrations (TECs) and probable effect concentrations (PECs; table 4) to determine if transects downstream had greater frequencies and magnitudes of exceedance than transects upstream from the five bridge sites. Additionally, trace-metal concentrations were normalized to aluminum to compute ERs of downstream sediment in relation to upstream sediment.

Composite trace-metal concentrations in bridge-deck sediment among the five bridge sites had similar patterns of occurrence (table 13; fig. 34A). Among the individual trace metals, concentrations ranged orders of magnitude with iron and aluminum having the greatest concentrations (1,000 to 10,000 milligrams per kilograms $[\mathrm{mg} / \mathrm{kg}]$ range). Manganese and zinc concentrations tended to be between 100 and $1,000 \mathrm{mg} / \mathrm{kg}$. Copper, chromium, and lead concentrations tended to fall within the range of 10 to $100 \mathrm{mg} / \mathrm{kg}$ and were the most variable among bridge sites. Arsenic and cobalt concentrations fell between 1 and $15 \mathrm{mg} / \mathrm{kg}$. Selenium and cadmium had the lowest concentration ranges of less than $1 \mathrm{mg} / \mathrm{kg}$. The Fishing bridge site more frequently had the highest trace-metal concentrations compared to the other bridge sites, followed by the Turkey bridge site (fig. 34A).

E. coli concentrations in bridge-deck sediment generally were less than 10 most probably number per gram of sediment (MPN/g), with the exception of NFEdisto bridge deck, which had E. coli concentrations greater than 30,000 MPN/g (table 13). This finding, in conjunction with the statistically significant increase in E. coli concentrations in the stream water downstream from the bridge during storms at the NFEdisto bridge site (table 10; fig. 33), implied bridge-deck runoff as a potential source of E. coli to the stream. E. coli concentrations increased by 2 to $39 \mathrm{MPN} / 100 \mathrm{~mL}$ (1.8 to 28 percent) downstream from this bridge site during five of the six storms (Romanok and others, 2020). However, only $E$. coli concentrations in stream water at the remaining storm exceeded the SCDHEC criterion of $349 \mathrm{MPN} / 100 \mathrm{~mL}$, and these elevated concentrations were observed at upstream and downstream transects. Therefore, although bridge-deck runoff could be contributing $E$. coli to the stream water at the NFEdisto bridge site, the increases are minor (and within the error of the microbiological analysis) and do not seem to be the primary cause of $E$. coli concentrations in excess of criterion levels.
As was observed with trace metals, PAH concentrations had a similar pattern of occurrence in bridge-deck sediment among bridge sites (fig. 34B). More persistence high molecular weight (HMW )PAHs, especially fluoranthene, pyrene, and benzo $[b]$ fluoranthene, were detected in greater concentrations than low molecular weight (LMW) PAHs, with the exception of the one-time, low-level occurrence of the HMW dibenzo $[a, h]$ anthracene at the Lynches bridge site (table 14; fig. 34B; appendix table 3.6, available for download at https://doi.org/10.3133/sir20205046; Leahy and Colwell, 1990; Romanok and others, 2020). Among the individual PAHs, concentrations ranged orders of magnitude with most of the HMW PAH concentrations ranging from 100 to 1,000 micrograms per kilogram $(\mu \mathrm{g} / \mathrm{kg})$ and the LMW PAH concentrations ranging from 1 to $100 \mu \mathrm{g} / \mathrm{kg}$ (table 14; fig. 34B). For comparison purposes, the $17 \mathrm{PAH}$ compounds that were determined in water and sediment samples plus perylene were assessed together and denoted as PAH-18 compounds. Although the number of detected PAH-18 compounds in bridge-deck sediment were relatively consistent among the five bridge sites (16 to 19), the $\Sigma$ PAH-18 concentrations had a much greater range, from 877.4 (Turkey bridge site) to 4,250.1 (Lynches bridge site) $\mu \mathrm{g} / \mathrm{kg}$ (table 14). However, the number of detected $\Sigma$ PAH-18 concentrations correlated positively with AADT counts at the five bridge sites $(n=5$, Spearman $\rho=1.000, p$-value $=0.0167)$.

At the Lynches site, the three PAHs detected in the water column were not detected in the streambed sediment at the downstream and upstream transects during the sediment survey. In fact, perylene was the only PAH compound detected $(2.55 \mu \mathrm{g} / \mathrm{kg} ; \mathrm{LRL}=25 \mu \mathrm{g} / \mathrm{kg})$ in streambed sediment, and it was detected only at the Lynches bridge site at the downstream transect (appendix table 3.6; Romanok and others, 2020). However, fluoranthene, pyrene, and benzo[b] fluoranthene concentrations were as high as or higher than some of the highest concentrations of all the PAH compounds analyzed in the bridge-deck sediment $(737,544$, and $582 \mu \mathrm{g} /$ $\mathrm{kg}$, respectively). Therefore, the bridge deck could have been the source of the low-level detection of pyrene and benzo[b] fluoranthene in the stream water during one of the five storms.

Trace-metal concentrations in composited streambed sediments at upstream and downstream transects at the five bridge sites were compared to corresponding TEC and PEC concentrations to determine if trace metals accumulated in the bed sediment above levels that could (TEC) or probably do (PEC) affect the health of benthic macroinvertebrate communities (table 4; Ingersoll and others, 2000; MacDonald and others, 2000). In general, trace-metal concentrations were below the TEC and PEC levels at all sites. Only one exception was identified and that was for a chromium concentration in the bed sediment at the upstream transect at the Fishing bridge site of $45.1 \mathrm{mg} / \mathrm{kg}$, that just exceeded the TEC of $43.4 \mathrm{mg} / \mathrm{kg}$ (tables 4, 13).

As described earlier, aluminum-normalized trace-metal concentrations were computed and used to develop ERs of the trace-metal concentrations in downstream sediment. Based on 
past studies, sediment ER values of $0.5 \leq \mathrm{ER} \leq 1.5$ were assumed to indicate no change in upstream metal concentrations. ER values of greater than 1.5 were assumed to indicate enrichment whereby a part of trace metal in sediment is derived from accumulation of non-natural processes or anthropogenic (for this study, bridge-deck runoff) sources (Zhang and others, 2009). Most of the bridge sites had ERs for 12 trace metals that did not indicate any change in trace-metal concentrations in downstream bed sediment (table 15). Exceptions did exist, especially at the Lynches bridge site where lead had an ER $>2$, indicating enrichment (fig. 35). However, the Lynches bridge site also had ERs $<0.5$ for chromium, cobalt, copper, iron, manganese, molybdenum, and vanadium, indicating a dilution or reduction in these sediment metal concentrations downstream from the bridge (fig. 35; table 15). The Fishing bridge site also had an ER $>2$ for manganese. Spearman correlation analysis was conducted between actual and aluminum-normalized trace-metal concentrations and potential source terms of AADT counts and bridge deck area as identified in Wagner and others (2011). The $\alpha$ level for the Spearman correlation was selected to be 0.10 . Aluminumnormalized copper concentrations in the bridge-deck sediment at the five bridge sites were positively correlated to AADT counts $(\rho=0.900, p$-value $=0.083$ ). Conversely, aluminumnormalized selenium concentrations at the five bridge sites were negatively correlated to AADT counts $(\rho=-1.000$, $p$-value $=0.0167$ ). Bridge-deck area was not significantly correlated to trace-metal concentrations at the five bridge sites.

Based on these findings, trace-metal concentrations in the streambed sediment upstream and downstream from the bridges were below levels expected to have probable effects on the aquatic biota, including the benthic macroinvertebrate community. Overall, no change (enrichment) in trace-element concentrations in bed sediment with known PECs and TECs was indicated downstream from the bridge at all bridge sites, except for lead at the Lynches bridge site. For the period of study at the selected bridge sites, bridge-deck runoff did not seem to affect trace-metal accumulation in the streambed sediment downstream from the bridge.

PAH concentrations in composited streambed sediments at transects upstream and downstream from the five bridge sites were compared to corresponding TEC and PEC concentrations to determine if PAHs accumulated in the streambed sediment above levels that could (TEC) or probably do (PEC) affect the health of benthic macroinvertebrate communities (table 4; Ingersoll and others, 2000; MacDonald and others, 2000). Concentrations of individual PAHs and the $\Sigma$ PAH-18 did not exceed any TEC or PEC (tables 4, 14; appendix table 3.6; Romanok and others, 2020), indicating
PAH concentrations in the streambed sediment at downstream and upstream transects were not likely to affect aquatic biota.

Nonetheless, the NFEdisto and SFEdisto bridge sites had $\Sigma$ PAH-18 sediment concentrations that were lower downstream (584.2 and $60.77 \mu \mathrm{g} / \mathrm{kg}$, respectively) than upstream $(1,045$ and $195.1 \mu \mathrm{g} / \mathrm{kg}$, respectively) from the bridge (appendix table 3.6; Romanok and others, 2020). In contrast, the Turkey and Fishing bridge sites had greater $\Sigma$ PAH-18 concentrations in the downstream sediment (105.8 and $85.81 \mu \mathrm{g} / \mathrm{kg}$, respectively) than in the upstream sediment ( 0 and $28.57 \mu \mathrm{g} / \mathrm{kg}$, respectively). Although the $\Sigma$ PAH-18 levels in downstream sediment at these sites were well below the TEC of $1,610 \mu \mathrm{g} / \mathrm{kg}$, the 3 - to 100 -fold increase in downstream concentrations demonstrated the strong probability of a bridge-runoff source.

Ratios of certain PAHs can be used to assess the source of PAH in different environments (table 5, Yunker and others, 2002). Therefore, PAH source ratios of selected PAH compounds in the bridge-deck sediment and streambed sediment at each site were compared to assess if the bridge deck could be source of the PAH in the streambed sediment. The ratio of fluoranthene/(fluoranthene+pyrene) seemed to be the most diagnostic of the ratios assessed in this study. When compared to indeno[1,2,3-cd]pyrene/(indeno[1,2,3-cd] pyrene+benzo[ghi]perylene) ratios, the source of bridge deck PAHs seemed to be coal or wood combustion rather than petroleum or petroleum combustion (Yunker and others, 2002). At the NFEdisto and SFEdisto bridge sites, the ratio of fluoranthene/(fluoranthene+pyrene) were similar between the bridge-deck sediment and upstream and downstream streambed sediment (fig. 36). At the Fishing and Turkey bridge sites, where increases in PAH concentrations were identified in the downstream sediment, the fluoranthene/ (fluoranthene+pyrene) ratio of the bridge-deck sediment matched only that at the downstream streambed sediment transect. The corresponding indeno[1,2,3-cd] pyrene/ (indeno $[1,2,3-c d]$ pyrene+benzo $[g h i]$ perylene) ratios in the bridge-deck sediment matched upstream and downstream streambed sediment at the NFEdisto bridge site only. The fluoranthene/(fluoranthene+pyrene) ratios seemed to suggest that the source of PAHs in the bridge-deck sediment was similar to the source for the downstream sediment at the Fishing and Turkey bridge sites and for downstream and upstream sediment at the NFEdisto and SFEdisto bridge sites. However, except for the NFEdisto bridge site, the lack of similarity between bridge-deck and streambed sediment PAHs ratios for the indeno[1,2,3-cd]pyrene/(indeno[1,2,3-cd] pyrene+benzo[ghi]perylene) makes source determination inconclusive. 
[Bold value is above the threshold effects concentration. $\mathrm{ft}$, foot; $\mathrm{ft} / \mathrm{s}$, cubic foot per second; MPN/g, most probable number per gram; DS, transect downstream from the bridge; NA, not available; $<$, less than; US, transect upstream from the bridge]

\begin{tabular}{|c|c|c|c|c|c|c|c|c|c|c|c|}
\hline \multirow[t]{2}{*}{$\begin{array}{l}\text { Site } \\
\text { ID }\end{array}$} & \multirow[t]{2}{*}{$\begin{array}{l}\text { Date of } \\
\text { sample }\end{array}$} & \multirow[t]{2}{*}{$\begin{array}{l}\text { Time of } \\
\text { sample }\end{array}$} & \multirow[t]{2}{*}{ Location } & \multirow{2}{*}{$\begin{array}{l}\text { Sample location, } \\
\text { distance } \\
\text { downstream (ft) }\end{array}$} & \multirow{2}{*}{$\begin{array}{l}\text { Sample location, } \\
\text { distance } \\
\text { upstream (ft) }\end{array}$} & \multirow[t]{2}{*}{$\begin{array}{c}\text { Streamflow } \\
\left(\mathrm{ft}^{3} / \mathrm{s}\right)\end{array}$} & \multirow[t]{2}{*}{$\begin{array}{l}\text { Escherichia } \\
\text { coli (MPN/g) }\end{array}$} & \multicolumn{4}{|c|}{$\begin{array}{l}\text { Recoverable metal concentrations in stream- } \\
\text { bed and bridge-deck sediment (milligram per } \\
\text { kilogram) }\end{array}$} \\
\hline & & & & & & & & Aluminum & Cadmium & Chromium & Cobalt \\
\hline \multicolumn{12}{|c|}{ Streambed sediment } \\
\hline \multirow[t]{2}{*}{ Fishing } & $12 / 01 / 2016$ & 1100 & DS & 38 & NA & 0.52 & NA & 1,497 & $<0.1$ & 9.03 & 3.10 \\
\hline & & 1130 & US & NA & 32 & 0.52 & NA & 2,691 & $<0.1$ & 45.1 & 6.39 \\
\hline \multirow[t]{2}{*}{ Lynches } & $08 / 27 / 2014$ & 0900 & DS & 50 & NA & 214 & NA & 594 & $<0.1$ & 0.63 & 0.2 \\
\hline & & 0930 & US & NA & 50 & 214 & NA & 444 & $<0.1$ & 0.81 & 0.71 \\
\hline \multirow[t]{2}{*}{ NFEdisto } & $08 / 28 / 2014$ & 0800 & DS & 50 & NA & 180 & NA & 636 & $<0.1$ & 0.84 & 0.23 \\
\hline & & 0830 & US & NA & 50 & 180 & NA & 993 & $<0.1$ & 1.93 & 0.25 \\
\hline \multirow[t]{2}{*}{ SFEdisto } & $08 / 12 / 2015$ & 0800 & DS & 50 & NA & 243 & NA & 3,387 & $<0.1$ & 2.87 & 1.93 \\
\hline & & 0900 & US & $\mathrm{NA}$ & 50 & 243 & NA & 2,669 & $<0.1$ & 2.47 & 2.55 \\
\hline \multirow[t]{2}{*}{ Turkey } & $08 / 13 / 2015$ & 0800 & DS & 50 & NA & 0 & NA & 8,407 & $<0.1$ & 9.14 & 1.43 \\
\hline & & 0900 & US & NA & 40 & 0 & NA & 4,130 & $<0.1$ & 4.20 & 0.79 \\
\hline \multicolumn{12}{|c|}{ Bridge-deck sediment } \\
\hline Fishing & $06 / 22 / 2016$ & 0915 & Bridge deck & NA & NA & NA & 3 & 16,371 & 0.51 & 75.6 & 13.5 \\
\hline Lynches & $11 / 14 / 2013$ & 1200 & Bridge deck & NA & NA & NA & 8 & 3,009 & 0.15 & 46.2 & 1.31 \\
\hline NFEdisto & $11 / 13 / 2013$ & 1200 & Bridge deck & NA & NA & NA & 31,718 & 2,597 & 0.52 & 30.1 & 1.82 \\
\hline SFEdisto & $07 / 28 / 2015$ & 1200 & Bridge deck & NA & NA & NA & $<1$ & 3,653 & 0.21 & 15.8 & 1.02 \\
\hline Turkey & $07 / 28 / 2015$ & 0900 & Bridge deck & NA & NA & NA & $<1$ & 4,112 & 0.21 & 224 & 2.26 \\
\hline
\end{tabular}


Table 13. Trace-metal and Escherichia coli concentrations in bridge-deck and streambed sediment at the five selected bridge sites, South Carolina, 2013 to 2016. - Continued

[Bold value is above the threshold effects concentration. $\mathrm{ft}$, foot; $\mathrm{ft}^{3} / \mathrm{s}$, cubic foot per second; MPN/g, most probable number per gram; DS, transect downstream from the bridge; NA, not available; <, less than; US, transect upstream from the bridge]

\begin{tabular}{|c|c|c|c|c|c|c|c|c|c|c|c|c|c|}
\hline \multirow{2}{*}{$\begin{array}{l}\text { Site } \\
\text { ID }\end{array}$} & \multirow{2}{*}{$\begin{array}{l}\text { Date of } \\
\text { sample }\end{array}$} & \multirow{2}{*}{$\begin{array}{l}\text { Time of } \\
\text { sample }\end{array}$} & \multirow{2}{*}{ Location } & \multicolumn{10}{|c|}{ Recoverable metal concentrations in stream bed and bridge deck sediment (milligram per kilogram) } \\
\hline & & & & Copper & Iron & Lead & Manganese & Molybdenum & Nickel & Vanadium & Zinc & Arsenic & Selenium \\
\hline \multicolumn{14}{|c|}{ Streambed sediment } \\
\hline \multirow[t]{2}{*}{ Fishing } & $12 / 01 / 2016$ & 1100 & DS & 4.09 & 4,444 & 1.66 & 422 & 2.86 & 1.28 & 15.0 & 7.04 & 0.40 & $<0.1$ \\
\hline & & 1130 & US & 6.36 & 8,416 & 3.65 & 308 & 5.42 & 2.40 & 28.8 & 9.46 & 0.74 & $<0.2$ \\
\hline \multirow[t]{2}{*}{ Lynches } & $08 / 27 / 2014$ & 0900 & DS & 0.37 & 530 & 1.89 & 7.0 & $<0.1$ & 0.40 & 0.87 & 1.32 & 0.13 & $<0.1$ \\
\hline & & 0930 & US & 0.51 & 790 & 1.43 & 96.3 & $<0.1$ & 0.55 & 1.09 & 3.67 & 0.26 & $<0.1$ \\
\hline \multirow[t]{2}{*}{ NFEdisto } & $08 / 28 / 2014$ & 0800 & DS & 0.3 & 456 & 1.79 & 7.6 & $<0.1$ & 0.40 & 0.94 & 1.38 & 0.17 & $<0.1$ \\
\hline & & 0830 & US & 0.51 & 513 & 3.68 & 9.3 & $<0.1$ & 0.54 & 1.42 & 2.57 & 0.59 & $<0.1$ \\
\hline \multirow[t]{2}{*}{ SFEdisto } & $08 / 12 / 2015$ & 0800 & DS & 1.28 & 1,043 & 3.62 & 69.8 & $<0.1$ & 1.37 & 2.84 & 5.93 & 0.56 & 0.2 \\
\hline & & 0900 & US & 1.54 & 1,300 & 3.19 & 117 & $<0.1$ & 1.32 & 2.46 & 5.61 & 0.45 & 0.1 \\
\hline \multirow[t]{2}{*}{ Turkey } & $08 / 13 / 2015$ & 0800 & DS & 1.59 & 3,117 & 6.66 & 20.8 & $<0.1$ & 2.17 & 7.94 & 7.67 & 0.44 & 0.1 \\
\hline & & 0900 & US & 1.1 & 1,307 & 3.82 & 12.5 & $<0.1$ & 1.00 & 3.70 & 2.97 & 0.32 & $<0.1$ \\
\hline \multicolumn{14}{|c|}{ Bridge-deck sediment } \\
\hline Fishing & $06 / 22 / 2016$ & 0915 & Bridge deck & 95.8 & 32,546 & 33.1 & 894 & 7.3 & 35.7 & 69.3 & 252 & 4.75 & 0.4 \\
\hline Lynches & $11 / 14 / 2013$ & 1200 & Bridge deck & 46.9 & 10,510 & 18.5 & 246 & 1.97 & 6.97 & 12.6 & 93.6 & 1.37 & $<0.1$ \\
\hline NFEdisto & $11 / 13 / 2013$ & 1200 & Bridge deck & 44.4 & 15,530 & 29.3 & 168 & 1.68 & 10.8 & 14.6 & 239 & 2.36 & $<0.1$ \\
\hline SFEdisto & $07 / 28 / 2015$ & 1200 & Bridge deck & 38.6 & 5,774 & 27.9 & 103 & 1.23 & 4.55 & 7.5 & 263 & 1.27 & 0.1 \\
\hline Turkey & $07 / 28 / 2015$ & 0900 & Bridge deck & 21.8 & 24,880 & 13.8 & 1,225 & 2.27 & 9.91 & 23.0 & 132 & 1.67 & 0.2 \\
\hline
\end{tabular}



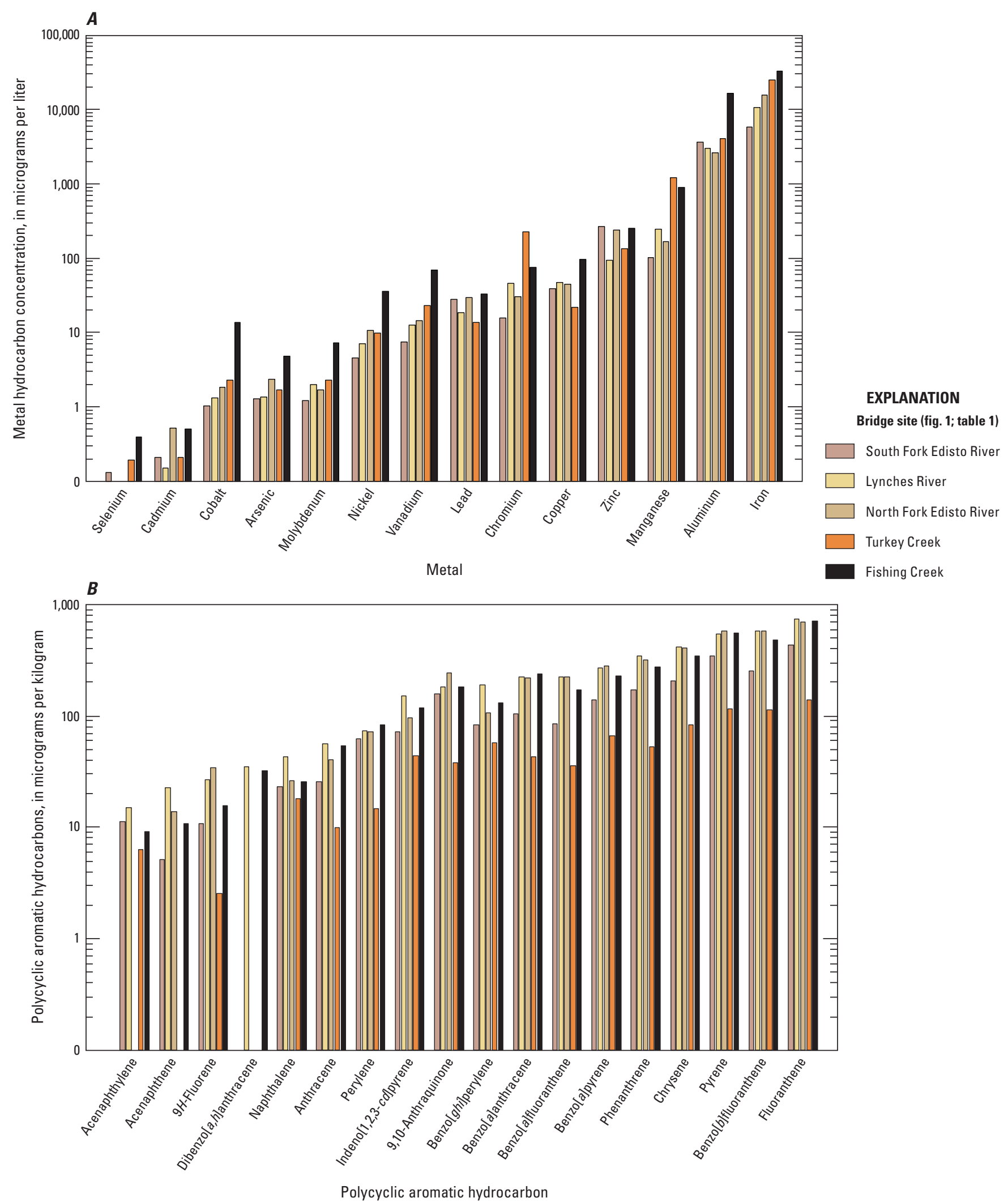

Figure 34. Graphs showing total metal and polycyclic aromatic hydrocarbon concentrations in bridge-deck sediment at the five selected bridge sites, South Carolina, 2013 to 2016. $A$, metals. B, polycyclic aromatic hydrocarbons. 
Table 14. Polycyclic aromatic hydrocarbon concentrations in streambed and bridge-deck sediment at the five selected bridge sites, South Carolina, 2013 to 2016.-Continued

[PAH, polycyclic aromatic hydrocarbon; g/mole, gram per mole, $\mu \mathrm{g} / \mathrm{kg}$, microgram per kilogram; DS, downstream relative to the bridge; US, upstream relative to the bridge; E, estimated; *PAH-18, concentrations of $18 \mathrm{PAH}$ compounds designated with an asterisk $(*) ; \Sigma$, sum; ND, not available]

\begin{tabular}{|c|c|c|c|c|c|c|c|c|c|c|c|c|c|c|c|c|c|}
\hline \multirow{3}{*}{ PAH compound } & \multirow{3}{*}{$\begin{array}{c}\text { Molecular } \\
\text { weight } \\
\text { (g/mole) }\end{array}$} & \multirow{3}{*}{$\begin{array}{l}\text { PAH } \\
\text { class }\end{array}$} & \multicolumn{10}{|c|}{ Streambed sediment concentration $(\mu \mathrm{g} / \mathrm{kg})$} & \multicolumn{5}{|c|}{ Bridge-deck sediment concentration( $\mu \mathrm{g} / \mathrm{kg})$} \\
\hline & & & \multicolumn{2}{|c|}{ Lynches $^{1}$} & \multicolumn{2}{|c|}{ NFEdisto ${ }^{1}$} & \multicolumn{2}{|c|}{ SFEdisto ${ }^{1}$} & \multicolumn{2}{|c|}{ Turkey' } & \multicolumn{2}{|c|}{ Fishing ${ }^{1}$} & \multirow{2}{*}{ Lynches $^{1}$} & \multirow{2}{*}{ NFEdisto ${ }^{1}$} & \multirow{2}{*}{ SFEdisto ${ }^{1}$} & \multirow{2}{*}{ Turkey' } & \multirow{2}{*}{ Fishing ${ }^{1}$} \\
\hline & & & DS & US & DS & US & DS & US & DS & US & DS & US & & & & & \\
\hline Carbazole & 167 & LMW & $<25$ & $<25$ & 7.09 & 12.8 & $<50$ & $<50$ & $<50$ & $<50$ & $<50$ & $<50$ & 79.3 & 82.1 & 41.3 & 12.7 & 59.8 \\
\hline Phenanthridine & 179 & LMW & $<25$ & $<25$ & $<25$ & $<25$ & $<50$ & $<50$ & $<50$ & $<50$ & $<50$ & $<50$ & 12.1 & 24.4 & $<50$ & $<50$ & $<50$ \\
\hline Dibenzothiophene & 184 & LMW & $<25$ & $<25$ & $<25$ & 3.34 & $<50$ & $<50$ & $<50$ & $<50$ & $<50$ & $<50$ & 18.7 & $<22.5$ & $<50$ & $<50$ & 15.9 \\
\hline $\begin{array}{l}\text { 4H-Cyclopenta } \\
{[\text { def }] \text { phenan- }} \\
\text { threne }\end{array}$ & 190 & LMW & $<25$ & $<25$ & $<25$ & 7.9 & $<50$ & $<50$ & $<50$ & $<50$ & $<50$ & $<50$ & 38.2 & 43.5 & 20.9 & 5.659 & 33.2 \\
\hline $\begin{array}{l}\text { 9,10-Anthraqui- } \\
\text { none }\end{array}$ & 208 & LMW & $<25$ & $<25$ & 16.7 & 34.8 & $<50$ & $<50$ & $<50$ & $<50$ & $<50$ & $<50$ & E184 & 244 & 159 & 38 & 181 \\
\hline $\begin{array}{l}\text { 1,6-Dimethyl- } \\
\text { naphthalene }\end{array}$ & 156 & LMW & $<25$ & $<25$ & $<25$ & 2.99 & $<50$ & $<50$ & $<50$ & $<50$ & $<50$ & $<50$ & 10.7 & 80.8 & E7.49 & 4.99 & E9.03 \\
\hline $\begin{array}{l}\text { 2,6-Dimethyl- } \\
\text { naphthalene }\end{array}$ & 156 & LMW & $<25$ & $<25$ & $<25$ & $<25$ & E2.03 & $<50$ & $<50$ & $<50$ & $<50$ & $<50$ & E11.8 & 114 & $<50$ & E5.48 & $<50$ \\
\hline $\begin{array}{l}\text { 1,2-Dimethyl- } \\
\text { naphthalene }\end{array}$ & 156 & LMW & $<25$ & $<25$ & $<25$ & $<25$ & $<50$ & $<50$ & $<50$ & $<50$ & $<50$ & $<50$ & 4.32 & $<22.7$ & 2.805 & $<50$ & $<50$ \\
\hline $\begin{array}{c}\text { 2,3,6-Trimethyl- } \\
\text { naphthalene }\end{array}$ & 170 & LMW & $<25$ & $<25$ & $<25$ & $<25$ & $<50$ & $<50$ & $<50$ & $<50$ & $<50$ & $<50$ & 3.71 & 63 & $<50$ & $<50$ & $<50$ \\
\hline $\begin{array}{l}\text { 2-Ethylnaphtha- } \\
\text { lene }\end{array}$ & 156 & LMW & $<25$ & $<25$ & $<25$ & $<25$ & $<50$ & $<50$ & $<50$ & $<50$ & $<50$ & $<50$ & E5.48 & 38.8 & $<50$ & $<50$ & $<50$ \\
\hline $\begin{array}{l}\text { 1-Methyl-9H- } \\
\text { fluorene }\end{array}$ & 180 & LMW & $<25$ & $<25$ & $<25$ & 1.31 & $<50$ & $<50$ & $<50$ & $<50$ & $<50$ & $<50$ & 4.91 & $<30.2$ & $<50$ & $<50$ & $<50$ \\
\hline $\begin{array}{l}\text { 1-Methylphenan- } \\
\text { threne }\end{array}$ & 192 & LMW & $<25$ & $<25$ & 2.91 & 6.0 & $<50$ & $<50$ & $<50$ & $<50$ & $<50$ & $<50$ & 26.1 & 43.2 & 29.4 & 7.91 & 23.9 \\
\hline $\begin{array}{l}\text { 2-Methylanthra- } \\
\text { cene }\end{array}$ & 192 & LMW & $<25$ & $<25$ & $<25$ & $<25$ & $<50$ & $<50$ & $<50$ & $<50$ & $<50$ & $<50$ & $<21$ & $<22.5$ & $<50$ & $<50$ & $<50$ \\
\hline 1-Methylpyrene & 216 & LMW & $<25$ & $<25$ & 5.01 & 10.0 & $<50$ & $<50$ & $<50$ & $<50$ & $<50$ & $<50$ & 23.2 & 48.1 & 27.6 & 10.5 & 26.5 \\
\hline *Naphthalene & 128 & LMW & $<25$ & $<25$ & $<25$ & $<25$ & $<50$ & $<50$ & $<50$ & $<50$ & $<50$ & $<50$ & 42.8 & 26 & 23.1 & 18.2 & E25.6 \\
\hline *Acenaphthylene & 152 & LMW & $<25$ & $<25$ & $<25$ & 3.205 & $<50$ & $<50$ & $<50$ & $<50$ & $<50$ & $<50$ & 15.1 & $<22.5$ & 11.3 & 6.31 & 9.14 \\
\hline *Acenaphthene & 154 & LMW & $<25$ & $<25$ & $<25$ & 3.735 & $<50$ & $<50$ & $<50$ & $<50$ & $<50$ & $<50$ & 22.9 & 13.8 & 5.14 & $<50$ & 10.9 \\
\hline$* 9 H$-Fluorene & 166 & LMW & $<25$ & $<25$ & $<25$ & 3.07 & $<50$ & $<50$ & $<50$ & $<50$ & $<50$ & $<50$ & 26.7 & 34.1 & 10.8 & E2.54 & 15.6 \\
\hline *Phenanthrene & 178 & LMW & $<25$ & $<25$ & 23 & 48.4 & $<50$ & $<50$ & $<50$ & $<50$ & $<50$ & $<50$ & 345 & 318 & 172 & 53.3 & 274 \\
\hline *Anthracene & 178 & LMW & $<25$ & $<25$ & 3.28 & 6.21 & $<50$ & 5.672 & $<50$ & $<50$ & $<50$ & $<50$ & 56.6 & 40.7 & 25.9 & 9.95 & 54.3 \\
\hline *Fluoranthene & 202 & HMW & $<25$ & $<25$ & 86 & 169 & 11.2 & 25.1 & 23.5 & $<50$ & E16.2 & $<50$ & 737 & 697 & 437 & 139 & 706 \\
\hline *Pyrene & 202 & HMW & $<25$ & $<25$ & 67.5 & 132 & 9.44 & 21.1 & 19.7 & $<50$ & E12.1 & $<50$ & 544 & 583 & 345 & 116 & 553 \\
\hline $\begin{array}{l}* \text { Benzo }[a] \\
\quad \text { anthracene }\end{array}$ & 228 & HMW & $<25$ & $<25$ & 31.5 & 58.4 & $<50$ & 16.6 & 9.95 & $<50$ & E7.9 & $<50$ & 223 & 221 & 105 & 42.6 & 236 \\
\hline
\end{tabular}


[PAH, polycyclic aromatic hydrocarbon; $\mathrm{g} /$ mole, gram per mole, $\mu \mathrm{g} / \mathrm{kg}$, microgram per kilogram; DS, downstream relative to the bridge; US, upstream relative to the bridge; E, estimated; *PAH-18, concentrations of $18 \mathrm{PAH}$ compounds designated with an asterisk (*); $\Sigma$, sum; ND, not available]

\begin{tabular}{|c|c|c|c|c|c|c|c|c|c|c|c|c|c|c|c|c|c|}
\hline \multirow{3}{*}{ PAH compound } & \multirow{3}{*}{$\begin{array}{c}\text { Molecular } \\
\text { weight } \\
\text { (g/mole) }\end{array}$} & \multirow{3}{*}{$\begin{array}{l}\text { PAH } \\
\text { class }\end{array}$} & \multicolumn{10}{|c|}{ Streambed sediment concentration $(\mu \mathrm{g} / \mathrm{kg})$} & \multicolumn{5}{|c|}{ Bridge-deck sediment concentration $(\mu \mathrm{g} / \mathrm{kg})$} \\
\hline & & & \multicolumn{2}{|c|}{ Lynches $^{1}$} & \multicolumn{2}{|c|}{ NFEdisto ${ }^{1}$} & \multicolumn{2}{|c|}{ SFEdisto ${ }^{1}$} & \multicolumn{2}{|c|}{ Turkey' } & \multicolumn{2}{|c|}{ Fishing' } & \multirow{2}{*}{ Lynches ${ }^{1}$} & \multirow{2}{*}{ NFEdisto ${ }^{1}$} & \multirow{2}{*}{ SFEdisto ${ }^{1}$} & \multirow{2}{*}{ Turkey' } & \multirow{2}{*}{ Fishing ${ }^{1}$} \\
\hline & & & DS & US & DS & US & DS & US & DS & US & DS & US & & & & & \\
\hline *Chrysene & 228 & HMW & $<25$ & $<25$ & 49.3 & 93 & $<50$ & 15.5 & 11.3 & $<50$ & E7.90 & $<50$ & 412 & 407 & 206 & 84.1 & 347 \\
\hline *Benzo $[a]$ pyrene & 252 & HMW & $<25$ & $<25$ & 43.9 & 73.2 & $<50$ & 17.6 & 13.1 & $<50$ & $<50$ & $<50$ & 270 & 279 & 139 & 66 & 231 \\
\hline $\begin{array}{l}\text { *Benzo }[b] \text { fluoran- } \\
\text { thene }\end{array}$ & 252 & HMW & $<25$ & $<25$ & 91.1 & 146 & 11.4 & 33.8 & 17.9 & $<50$ & E13.7 & E4.17 & 582 & 578 & 256 & 113 & 484 \\
\hline *Benzo[e]pyrene & 252 & HMW & $<25$ & $<25$ & 49.6 & 83.4 & E5.43 & 15.4 & 10.4 & $<50$ & $<50$ & $<50$ & 278 & 292 & 152 & 74.7 & 238 \\
\hline $\begin{array}{l}\text { *Benzo }[k] \text { fluoran- } \\
\text { thene }\end{array}$ & 252 & HMW & $<25$ & $<25$ & 31.6 & 50 & $<50$ & 9.926 & $<50$ & $<50$ & $<50$ & $<50$ & 226 & 225 & 85.1 & 35.6 & 173 \\
\hline *Perylene & 252 & HMW & $<25$ & 2.55 & 12.6 & 22.5 & 23.3 & 25.3 & $<50$ & $<50$ & 20.9 & 24.4 & 74.3 & 72.7 & 63 & 14.6 & 82.4 \\
\hline $\begin{array}{c}* \text { Benzo }[g h i] \\
\text { perylene }\end{array}$ & 276 & HMW & $<25$ & $<25$ & 43.4 & 69.9 & $<50$ & $<50$ & $<50$ & $<50$ & $<50$ & $<50$ & 190 & 107 & E 82.5 & E57.7 & 132 \\
\hline $\begin{array}{l}* \text { Indeno }[1,2,3-c d] \\
\text { pyrene }\end{array}$ & 276 & HMW & $<25$ & $<25$ & E39.5 & E61.0 & $<50$ & E9.06 & $<50$ & $<50$ & E7.06 & $<50$ & E151 & E95.4 & E71.8 & E43.8 & E119 \\
\hline \multirow{3}{*}{$\begin{array}{c}* \text { Dibenzo }[a, h] \\
\text { anthracene }\end{array}$} & 278 & HMW & $<25$ & $<25$ & E11.9 & E18.6 & $<50$ & $<50$ & $<50$ & $<50$ & $<50$ & $<50$ & E35 & $<22.5$ & $<50$ & $<50$ & E32.1 \\
\hline & \multicolumn{2}{|c|}{ Detected *PAH-18 } & ND & 1 & 14 & 18 & 5 & 11 & 7 & ND & 7 & 2 & 19 & 16 & 17 & 16 & 19 \\
\hline & \multicolumn{2}{|c|}{$\Sigma *$ PAH- 18} & ND & 2.55 & 584.2 & $1,045.0$ & 60.77 & 195.1 & 105.8 & ND & 85.81 & 28.57 & $4,250.10$ & $3,989.70$ & $2,190.60$ & 877.4 & $3,738.90$ \\
\hline \multicolumn{3}{|c|}{ Anthracene/(Anthracene+Phenanthrene) } & ND & ND & 0.12 & 0.11 & ND & ND & ND & ND & ND & ND & 0.14 & 0.11 & 0.13 & 0.16 & 0.17 \\
\hline \multicolumn{3}{|c|}{ Fluoranthene/(Fluoranthene+Pyrene) } & ND & ND & 0.56 & 0.56 & 0.54 & 0.54 & 0.54 & ND & 0.57 & ND & 0.58 & 0.54 & 0.56 & 0.55 & 0.56 \\
\hline \multicolumn{3}{|c|}{$\begin{array}{r}\text { Indeno[ }[1,2,3-c d] \text { pyrene/(Indeno }[1,2,3-c d] \\
\text { pyrene+Benzo }[\text { ghi }] \text { perylene })\end{array}$} & ND & ND & 0.48 & 0.47 & ND & ND & ND & ND & ND & ND & 0.44 & 0.47 & 0.47 & 0.43 & 0.47 \\
\hline
\end{tabular}

${ }^{1}$ See station numbers and full names in table 1 . 
Table 15. Aluminum-normalized metal concentrations and metal enrichment factors in bridge-deck and streambed sediment collected at the five selected bridge sites, South Carolina, 2013 to 2016.

[ID, identifier; ND, not detected; DS, transect downstream from the bridge; US, transect upstream from the bridge; ER, enrichment ratios computed as the aluminum-normalized metal concentration at the transect downstream from the bridge divided by the aluminum-normalized metal concentration at the transect upstream from the bridge after Sinex and Helz (1981); yellow highlighted ER levels indicate potential reduction in metal concentrations downstream from the bridge (Zhang and others, 2009); red highlighted ER levels indicate potential enrichment in metal concentration downstream from the bridge]

\begin{tabular}{|c|c|c|c|c|c|c|c|c|c|c|c|c|c|}
\hline \multirow{2}{*}{$\begin{array}{c}\text { Site ID } \\
\text { (table 1) }\end{array}$} & \multicolumn{13}{|c|}{ Aluminum normalized metal concentrations in sediment (unitless) } \\
\hline & Cadmium & Chromium & Cobalt & Copper & Iron & Lead & Manganese & Molybdenum & Nickel & Vanadium & Zinc & Arsenic & Selenium \\
\hline \multicolumn{14}{|c|}{ Bridge deck } \\
\hline Fishing & 0.00003 & 0.00462 & 0.00082 & 0.00585 & 1.98803 & 0.00202 & 0.05459 & 0.00045 & 0.00218 & 0.00423 & 0.01537 & 0.00029 & 0.00002 \\
\hline Lynches & 0.00005 & 0.01535 & 0.00044 & 0.01559 & 3.49285 & 0.00614 & 0.08166 & 0.00065 & 0.00232 & 0.00419 & 0.03110 & 0.00046 & ND \\
\hline NFEdisto & 0.00020 & 0.01159 & 0.00070 & 0.01710 & 5.97998 & 0.01130 & 0.06454 & 0.00065 & 0.00415 & 0.00561 & 0.09207 & 0.00091 & ND \\
\hline SFEdisto & 0.00006 & 0.00433 & 0.00028 & 0.01057 & 1.58062 & 0.00764 & 0.02806 & 0.00034 & 0.00125 & 0.00205 & 0.07203 & 0.00035 & 0.00004 \\
\hline Turkey & 0.00005 & 0.05446 & 0.00055 & 0.00531 & 6.05058 & 0.00335 & 0.29791 & 0.00055 & 0.00241 & 0.00558 & 0.03218 & 0.00041 & 0.00005 \\
\hline \multicolumn{14}{|c|}{ Streambed DS } \\
\hline Fishing & ND & 0.00603 & 0.00207 & 0.00273 & 2.96860 & 0.00111 & 0.28216 & 0.00191 & 0.00086 & 0.01005 & 0.0047 & 0.00027 & ND \\
\hline Lynches & ND & 0.00106 & 0.00034 & 0.00062 & 0.89126 & 0.00318 & 0.01172 & ND & 0.00067 & 0.00146 & 0.00222 & 0.00022 & ND \\
\hline NFEdisto & ND & 0.00132 & 0.00036 & 0.00047 & 0.71682 & 0.00281 & 0.01193 & ND & 0.00063 & 0.00148 & 0.00217 & 0.00027 & ND \\
\hline SFEdisto & ND & 0.00085 & 0.00057 & 0.00038 & 0.30794 & 0.00107 & 0.02062 & ND & 0.00040 & 0.00084 & 0.00175 & 0.00017 & 0.00007 \\
\hline Turkey & ND & 0.00109 & 0.00017 & 0.00019 & 0.37076 & 0.00079 & 0.00247 & ND & 0.00026 & 0.00094 & 0.00091 & 0.00005 & ND \\
\hline \multicolumn{14}{|c|}{ Streambed US } \\
\hline Fishing & ND & 0.01675 & 0.00238 & 0.00236 & 3.12746 & 0.00136 & 0.1146 & 0.00201 & 0.00089 & 0.01071 & 0.00352 & 0.00028 & ND \\
\hline Lynches & ND & 0.00183 & 0.00160 & 0.00115 & 1.77976 & 0.00322 & 0.21716 & ND & 0.00124 & 0.00246 & 0.00827 & 0.00059 & ND \\
\hline NFEdisto & ND & 0.00194 & 0.00025 & 0.00051 & 0.51637 & 0.00371 & 0.00942 & ND & 0.00054 & 0.00143 & 0.00259 & 0.00059 & ND \\
\hline SFEdisto & ND & 0.00093 & 0.00096 & 0.00058 & 0.48707 & 0.00120 & 0.04376 & ND & 0.00049 & 0.00092 & 0.00210 & 0.00017 & 0.00005 \\
\hline Turkey & ND & 0.00102 & 0.00019 & 0.00027 & 0.31646 & 0.00092 & 0.00301 & ND & 0.00024 & 0.00090 & 0.00072 & 0.00008 & ND \\
\hline \multicolumn{14}{|c|}{ ER } \\
\hline Fishing & ND & 0.360 & 0.871 & 1.155 & 0.949 & 0.816 & 2.46 & 0.947 & 0.959 & 0.938 & 1.34 & 0.982 & ND \\
\hline Lynches & ND & 0.063 & 0.142 & 0.264 & 0.285 & 2.35 & 0.102 & $\mathrm{ND}$ & 0.754 & 0.137 & 0.632 & 0.795 & ND \\
\hline NFEdisto & ND & 0.679 & 1.44 & 0.918 & 1.39 & 0.759 & 1.27 & ND & 1.16 & 1.03 & 0.838 & 0.450 & ND \\
\hline SFEdisto & ND & 0.916 & 0.596 & 0.655 & 0.632 & 0.894 & 0.471 & ND & 0.818 & 0.910 & 0.833 & 0.981 & 1.45 \\
\hline Turkey & ND & 1.07 & 0.889 & 0.71 & 1.172 & 0.856 & 0.821 & ND & 1.07 & 1.054 & 1.27 & 0.675 & ND \\
\hline
\end{tabular}




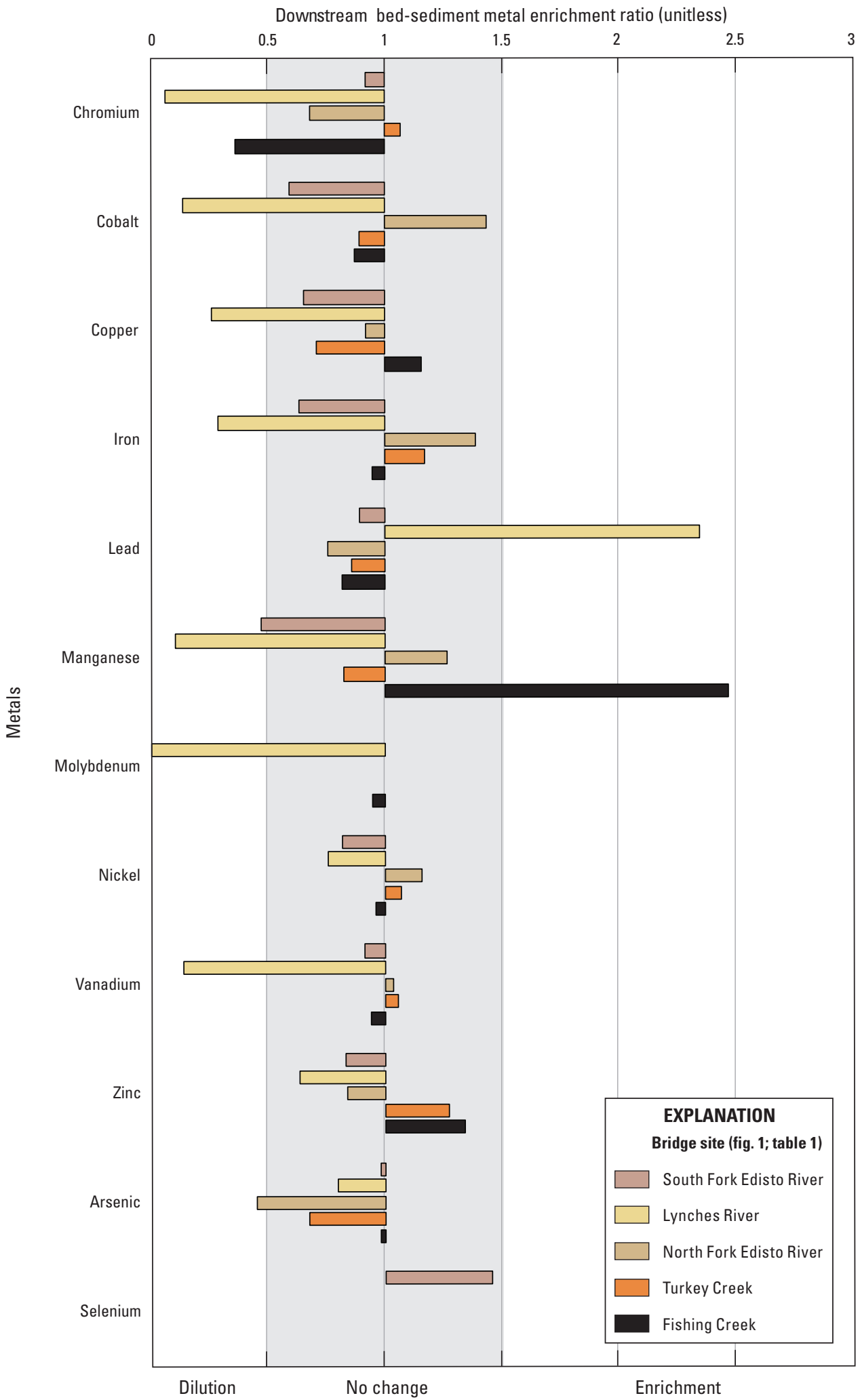

Figure 35. Graph showing metal enrichment ratios, computed from aluminum-normalized metal concentrations, in downstream streambed sediment compared to upstream streambed sediment at the five selected bridge sites, South Carolina. 


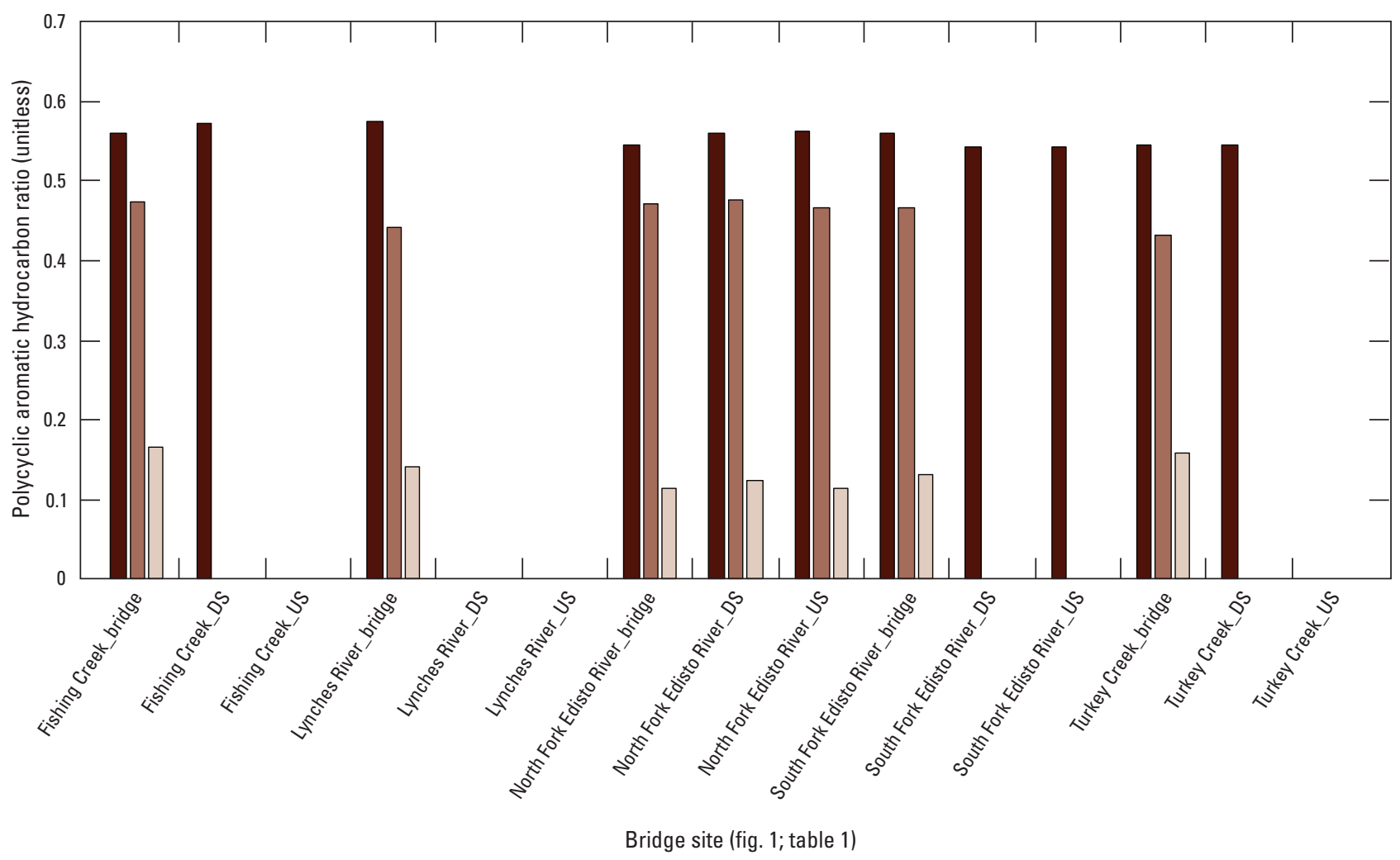

EXPLANATION

Polycyclic aromatic hydrocarbon ratio (table 5)

Fluoranthene/(Fluoranthene+Pyrene)

Indeno[1,2,3-cd]pyrene/(Indeno[1,2,3-cd]pyrene+ Benzo[ghi]perylene)

Anthracene/(Anthracene+Phenanthrene)

Figure 36. Graph showing polycyclic aromatic hydrocarbon ratios in bridge-deck sediment and streambed sediment upstream and downstream from the five selected bridge sites, South Carolina, 2013 to 2016. 


\section{Benthic Macroinvertebrate Assemblages}

Feeding behaviors of benthic macroinvertebrates represent their adaption to environmental conditions (Merritt and Cummins, 1996). Species of benthic macroinvertebrates usually comprise one of many functional feeding groups, including shredders that chew on wood, leaves, and living/ decaying plant tissue (generally, coarse particulate organic matter); collectors that filter and gather fine particulate organic material; scrapers that rasp biofilms and periphyton from rocks and woody debris; predators that engulf or pierce whole animals or animal tissues; piercers that suck living hydrophytes (plants); and parasites that invade living animal or plant tissue. Additionally, different species have different tolerances to degrading water-quality conditions and many have been assigned tolerance values that can be used to compute a biotic index of the benthic macroinvertebrate assemblage present in the stream (Lenat, 1993).

The Lynches bridge site had six deployed Hester-Dendy multiplate artificial substrates, but two were buried in sediment and not analyzed (table 3 ). Habitat was comparable at upstream and downstream transects and included sandy streambeds and partial canopy cover (appendix table 3.7, available for download at https://doi.org/10.3133/sir20205046; Romanok and others, 2020). Abundance and diversity of benthic macroinvertebrate assemblages demonstrated variability between the two Hester-Dendy substrates deployed upstream, as well as between the two deployed downstream. For upstream and downstream Hester-Dendy substrates at the Lynches bridge site, chronomids and tubificid worms had the greatest mean abundance of all the benthic macroinvertebrate families, followed by EPT taxa (table 16; Romanok and others, 2020). Within the Ephemeroptera family (mayflies) for all sites, three species whose functional feeding groups were collector/gather (CG) and filter/collector (FC) were most common (in order of greatest number of organisms): Caenis sp. (tolerance value $[\mathrm{TV}]=6.8 ; \mathrm{CG})$, Tricorythodes sp. $(\mathrm{TV}=5.0 ; \mathrm{CG})$, and Isonychia sp. $(\mathrm{TV}=3.6 ; \mathrm{FC})$. Within the Trichoptera family (caddisflies), FC Cheumatopsyche sp. $(\mathrm{TV}=6.6)$, followed by Chimarra sp. $(\mathrm{TV}=3.3)$, were the most common species. Only two species of Plecoptera were identified: Acroneuria abnormis (count=1 downstream) and Neoperla sp. (count=1 upstream). Overall, the ANOSIM routine in PRIMER corroborated the LINKTREE cluster analysis (with SIMPROF) that determined that benthic macroinvertebrate communities were similar between upstream and downstream transects at the Lynches bridge site (table 17; Global $R=1.00, p$-value=0.333). Additionally, metrics of North Carolina biotic indices (NCBIs), EPT taxa, Shannon-Weiner diversity indices, and Margalef species richness were computed and compared between upstream and downstream transects at the Lynches bridge site (appendix table 3.8, available for download at https://doi.org/10.3133/ sir20205046; fig. 37; Lenat, 1993; Romanok and others,
2020). At the Lynches bridge site, the downstream transect seemed to have more variable EPT taxa and NCBI than the upstream transect. Mean NCBIs at the upstream and downstream transects were within the rating for good-fair water-quality conditions (table 16; Lenat, 1993; fig. 37A). But, on average, mean metrics did not indicate decreased benthic macroinvertebrate health downstream from the bridge caused by bridge-deck runoff.

The NFEdisto bridge site also had six deployed Hester-Dendy multiplate artificial substrates, but only four were retrieved and analyzed because of sedimentation issues (table 3). Habitat was consistent at upstream and downstream transects and included sandy streambeds and partial canopy cover (appendix table 3.7; Romanok and others, 2020). Abundance and diversity of benthic macroinvertebrate assemblages demonstrated variability between the two upstream Hester-Dendy substrates as well as between the two downstream substrates (appendix table 3.8; table 16; Romanok and others, 2020). For upstream and downstream Hester-Dendy substrates, chronomids had the greatest species abundance of all the benthic taxa, followed by tubificid worms and EPT taxa. Within the Ephemeroptera family for all Hester-Dendy substrates, scrappers from the family Heptageniidae were most common, including species from the genus Maccaffertium. Within the Trichoptera family, a piercer Hydroptila sp. $(\mathrm{TV}=6.5)$, followed by FCs Cheumatopsyche sp. $(\mathrm{TV}=6.6)$ and Chimarra $\mathrm{sp} .(\mathrm{TV}=3.3)$, were the most common species. Acroneuria abnormis $(\mathrm{TV}=2.1)$ and Paragnetina fumosa (TV=3.6), although few, were the only species of Plecoptera identified in the upstream Hester-Dendy substrates, and only Acroneuria abnormis was present at one Hester-Dendy substrate downstream from the NFEdisto bridge site.

Overall, the ANOSIM routine in PRIMER determined that benthic macroinvertebrate communities were not statistically different between upstream and downstream transects at the NFEdisto site (table 17; Global $R=0.500$, $p$-value $=0.333$ ). Metrics of NCBI and Shannon-Weiner diversity index had similar patterns at the NFEdisto bridge site as was observed at the Lynches bridge site (appendix table 3.8; fig. 37; Romanok and others, 2020). At the NFEdisto bridge site, the downstream Hester-Dendy substrates seemed to have more variable NCBI than the upstream substrates. In fact, the NCBI at the upstream and downstream Hester-Dendy substrates was consistently in the good-fair region (fig. 37A). The computed mean metrics were similar between the upstream and downstream Hester-Dendy substrates (table 16), with the exception of greater species richness upstream compared to downstream. Overall, benthic macroinvertebrate health downstream from the bridge seemed to not be affected by bridge-deck runoff.

Adjustments to the benthic macroinvertebrate sampling protocol were made by increasing the number of Hester-Dendys deployed after 2014. At the Turkey bridge site, 14 Hester-Dendys were deployed: 7 upstream and 7 downstream from the bridge (table 3 ). Three of the seven 
Hester-Dendys upstream and downstream were placed sideby-side with another Hester-Dendy and were used as replicate samples. Habitat was variable upstream and downstream (appendix table 3.7; Romanok and others, 2020). Habitat at the upstream Hester-Dendys included marl or hard bottom and sandy streambeds with partial canopy cover. Habitat at the downstream Hester-Dendys included marl or hard bottom streambeds with partial canopy cover and sand-cobble mix streambeds with open canopy.

Of the five bridge sites in this study, the Turkey bridge site seemed to have the least healthy benthic macroinvertebrate communities because of the lowest EPT taxa, species richness, and diversity, and the highest biotic indices upstream and downstream (fig. 37; table 16; Romanok and other, 2020). Mean NCBIs dropped from fair at the upstream transect to poor at the downstream transect. This ecological finding was not unexpected because of seasonal periods of negligible flow when DO concentrations fell below $4 \mathrm{mg} / \mathrm{L}$ during routine and storm conditions during this study period (figs. 18A, 19D). The Turkey bridge site discharged to a small headwater stream during storms with an estimated bridgedeck runoff rate to streamflow (hydraulic loading estimate) ratio that ranged from $<0.1$ to 100 percent when streamflow approached zero. However, abundance and diversity of benthic macroinvertebrate assemblages demonstrated little variability between the upstream and downstream Hester-Dendys (appendix table 3.8; table 16; Romanok and others, 2020). For upstream and downstream Hester-Dendys, the family with the greatest mean species abundance was chronomids, followed by tubificid worms (table 16). Ephemeroptera was the only family of EPT to have any organisms present (table 16). Only three species dominated the benthic macroinvertebrates upstream and downstream. The most abundant species of all families was the CG Dero sp. (TV=9.8), a very pollutiontolerant species of tubificid worms. Likewise, the remaining dominant species were relatively tolerant species within the chronomid family: the FC Dicrotendipes $s p$. $(\mathrm{TV}=7.2)$ and the predator Ablabesmyia mallochi $(\mathrm{TV}=7.4)$.

The results of the ANOSIM routine determined that benthic macroinvertebrate communities were similar between upstream and downstream transects at the Turkey bridge site (table 17; Global $R=0.156, p$-value $=0.143$ ). Additional ANOSIM tests on quality-control samples of replicate and environmental Hester-Dendys also indicated similar benthic macroinvertebrate communities in replicate taxonomic results (Global $R=0.051, p$-value $=0.296$ ). Instead of grouping by location relative to the bridge, further ANOSIM tests on benthic macroinvertebrate communities were conducted among substrate types and canopy cover, which also indicated similar communities among the different habitat characteristics (table 17; Global $R=0.325$ and $0.260, p$-value $=0.110$ and 0.179 , respectively). ANOSIM tests on taxa only within the Diptera, Ephemeroptera, Plecoptera, and Trichoptera families indicated a potential, but not significant, difference in assemblages between upstream and downstream transects (Global $R=0.406, p$-value $=0.057$ ), along with different assemblages among substrate types (Global $R=0.388$, $p$-value $=0.067$ ).

At the SFEdisto site, the number of Hester-Dendy artificial substrates deployed also was increased to 14 , with 7 deployed upstream and 7 deployed downstream from the bridge. Three of the seven Hester-Dendys placed downstream were placed side-by-side with another Hester-Dendy and were used as replicate samples. One replicate-environmental pair of Hester-Dendys was lost, leaving only two replicate and three environmental samples. Habitat was variable upstream and downstream (appendix table 3.7; Romanok and others, 2020). Habitat at the upstream Hester-Dendys had cobble and bedrock streambeds with partial canopy cover. Habitat at the downstream Hester-Dendys had sandy streambeds with partial canopy cover.

Of the five bridge sites in this study, the SFEdisto bridge site seemed to have healthier benthic macroinvertebrate communities because of greater mean EPT taxa and lower mean biotic indices upstream and downstream (fig. 37; table 16). The greatest species abundance was observed in the chronomids, followed by EPT taxa. Within the Ephemeroptera family, scrapers in the Hetageniidae and Ephemerellidae had the greatest abundance as compared to CGs within Baetidae. Within the Trichoptera family, FC Chimarra sp. $(\mathrm{TV}=3.3)$ followed by piercer Hydroptila $\mathrm{sp} .(\mathrm{TV}=6.5)$ and FC Cheumatopsyche sp. $(\mathrm{TV}=6.6)$, were the most common species. The predator Acroneuria abnormis $(\mathrm{TV}=2.1)$ was the most abundant species in the Plecoptera family.

The results of the ANOSIM routine determined that benthic macroinvertebrate communities were similar between upstream and downstream transects at the SFEdisto bridge site (table 17; Global $R=0.204, p$-value $=0.171$ ). Further ANOSIM tests on replicate and environmental HesterDendys also indicated similar benthic macroinvertebrate communities. However, further ANOSIM tests on benthic macroinvertebrate communities among substrate types suggested a potential difference between Hester-Dendys deployed at sand rather than cobble or bedrock types (Global $R=0.530, p$-value $=0.067$ ). Additionally, ANOSIM tests on taxa only within the Diptera, Ephemeroptera, Plecoptera, and Trichoptera families indicated similar assemblages between upstream and downstream transects (Global $R=0.222$, $p$-value $=0.086$ ), but different assemblages among substrate types (Global $R=0.592, p$-value $=0.029$ ).

At the Fishing bridge site, the number of Hester-Dendy artificial substrates deployed was 14 (7 upstream and 7 downstream; table 3; appendix table 3.7; Romanok and others, 2020). One of the seven Hester-Dendys placed downstream placed side-by-side with another Hester-Dendy was used as replicate samples. Habitat at the upstream HesterDendys had cobble and bedrock streambeds with partial canopy cover. Habitat at the downstream Hester-Dendys had sandy streambeds with partial canopy cover. At the HesterDendys downstream, the streambed was sand and silt mix (no cobble) with full canopy cover. 
The Fishing bridge site was another case of a bridge discharging to a small headwater stream with seasonal streamflow below $1 \mathrm{ft}^{3} / \mathrm{s}$ and estimated bridge-deck runoff rate to streamflow ratios ranging from 0.16 to 43.3 , but less frequent periods of DO under $4 \mathrm{mg} / \mathrm{L}$ than the Turkey bridge site (table 2; figs. 28A, 29D). Additionally, the Fishing bridge site had increased TKN and turbidity in the stream water downstream from the bridge as compared to upstream (fig. 33). The upstream and downstream Hester-Dendys at the Fishing bridge site had a similar range of EPT taxa as the Turkey site, which was lower than the other three bridge sites (fig. 37). The Fishing bridge site also had better biotic indices, diversity indices, and species richness than the Turkey bridge site. Nonetheless, the Fishing bridge site had little change in these metrics between upstream and downstream transects (table 16). Most abundant species were the chronomids, including the CGs Microtendipes pedellus (TV=3.9) and Dicrotendipes sp. (TV=7.2), and the predator Labrundinia $s p .(\mathrm{TV}=6.2)$. Downstream Hester-Dendys tended to have a greater abundance than upstream, especially for less tolerant species of Microtendipes pedellus and Parakiefferiella sp.
(TV=4.8). The tubificid worm, Dero digita (TV=9.8), also was present in abundance at upstream and downstream Hester-Dendys. Although each of the EPT families had species present, their abundances were quite limited. No distinct separation in macroinvertebrate communities was identified by hierarchical cluster analysis (LINKTREE with SIMPROF). However, ANOSIM analysis indicated a statistically significant difference between upstream and downstream transects (Global $R=0.521, p$-value $=0.002$ ), but that difference could be attributed to statistical differences in substrate type because the upstream transect was a mix of sand, silt, and cobble, whereas the downstream transect was a mix of just sand and silt (no cobble) (ANOSIM Global $R=0.521, p$-value $=0.003$ ). The upstream transect at the Fishing bridge site had a greater range in species diversity and richness in benthic macroinvertebrate community than the downstream transect (figs. 37C, D), but the upstream transect tended to have NCBIs greater than 6.9 (fair), indicating the species present at the upstream transect were less sensitive than downstream (fig. 37A). 
Table 16. Computed mean metrics for the benthic macroinvertebrate communities collected from Hester-Dendy artificial substrates deployed for 8 weeks at transects downstream and upstream from the five selected bridge sites, South Carolina, 2014 to 2016.

[ID, identifier; EPT, Ephemeroptera, Plecoptera, and Trichoptera spp; NC, North Carolina]

\begin{tabular}{|c|c|c|c|c|c|c|c|c|c|c|c|c|c|}
\hline Site ID (table 1) & $\begin{array}{l}\text { Location } \\
\text { relative } \\
\text { to bridge }\end{array}$ & $\begin{array}{c}\text { Total } \\
\text { number of } \\
\text { organisms }\end{array}$ & $\begin{array}{c}\text { Total } \\
\text { number } \\
\text { of taxa }\end{array}$ & $\begin{array}{c}\text { Total } \\
\text { species }\end{array}$ & $\begin{array}{c}\text { Species } \\
\text { richness } \\
\text { (Margalef) }\end{array}$ & $\begin{array}{l}\text { Pielou's } \\
\text { evenness }\end{array}$ & $\begin{array}{l}\text { Shannon } \\
\text { Wiener } \\
\text { Diversity } \\
\text { Index }\end{array}$ & $\begin{array}{l}\text { Simpson } \\
\text { Diveristy } \\
\text { Index }\end{array}$ & $\begin{array}{l}\text { EPT } \\
\text { taxa }\end{array}$ & $\begin{array}{c}\text { NC } \\
\text { Biotic } \\
\text { Indexa }\end{array}$ & $\begin{array}{l}\text { Biotic } \\
\text { Index } \\
\text { Ratinga }\end{array}$ & $\begin{array}{c}\text { Number of } \\
\text { Hydropsychidae } \\
\text { (family in } \\
\text { Trichoptera) }\end{array}$ & $\begin{array}{l}\text { Percentage of } \\
\text { Hydropsychidae } \\
\text { in Trichoptera }\end{array}$ \\
\hline Lynches & DS & 571 & 49 & 43 & 6.67 & 0.77 & 2.9 & 0.9 & 11 & 6.6 & good-fair & 11 & 27 \\
\hline Lynches & US & 929 & 55 & 44 & 6.43 & 0.88 & 3.34 & 0.96 & 12 & 6.52 & good-fair & 31 & 45 \\
\hline NFEdisto & DS & 746 & 56 & 42 & 6.11 & 0.77 & 2.87 & 0.91 & 12 & 6.62 & good-fair & 9 & 16 \\
\hline NFEdisto & US & 620 & 51 & 50 & 7.9 & 0.78 & 3.04 & 0.91 & 12 & 6.68 & fair & 0 & 0 \\
\hline SFEdisto & DS & 1270 & 44 & 44 & 6.05 & 0.84 & 3.17 & 0.94 & 17 & 5.62 & good & 37 & 25 \\
\hline SFEdisto & US & 896 & 40 & 40 & 5.93 & 0.8 & 2.93 & 0.92 & 13 & 5.97 & good-fair & 6 & 28 \\
\hline Turkey & DS & 150 & 14 & 14 & 2.68 & 0.72 & 1.91 & 0.78 & 1 & 7.9 & poor & 0 & 0 \\
\hline Turkey & US & 138 & 13 & 13 & 2.42 & 0.74 & 1.9 & 0.79 & 1 & 7.66 & fair & 0 & 0 \\
\hline Fishing & DS & 422 & 31 & 31 & 5.07 & 0.78 & 2.66 & 0.87 & 3 & 6.73 & fair & 0 & 0 \\
\hline Fishing & US & 164 & 30 & 30 & 5.78 & 0.84 & 2.85 & 0.92 & 2 & 7.35 & fair & 0 & 0 \\
\hline
\end{tabular}


Table 16. Computed mean metrics for the benthic macroinvertebrate communities collected from Hester-Dendy artificial substrates

deployed for 8 weeks at transects downstream and upstream from the five selected bridge sites, South Carolina, 2014 to 2016. - Continued

\begin{tabular}{|c|c|c|c|c|c|c|c|c|c|}
\hline Site ID (table 1) & $\begin{array}{c}\text { EPT } \\
\text { abundance }\end{array}$ & $\begin{array}{c}\text { EPT abundance } \\
\text { minus } \\
\text { Hydropsychidae }\end{array}$ & $\begin{array}{c}\text { Diptera } \\
\text { abundance }\end{array}$ & $\begin{array}{l}\text { Chronomid } \\
\text { (family in } \\
\text { Diptera) } \\
\text { abundance }\end{array}$ & $\begin{array}{c}\text { Tubificid } \\
\text { (Tubificidae } \\
\text { family) } \\
\text { abundance }\end{array}$ & $\begin{array}{l}\text { Ephemeroptera } \\
\text { abundance }\end{array}$ & $\begin{array}{l}\text { Plecoptera } \\
\text { abundance }\end{array}$ & $\begin{array}{l}\text { Trichoptera } \\
\text { abundance }\end{array}$ & $\begin{array}{l}\text { Other } \\
\text { taxa }\end{array}$ \\
\hline Lynches & 54 & 43 & 192 & 187 & 164 & 32 & 0.5 & 22 & 161 \\
\hline Lynches & 156 & 124 & 489 & 479 & 77 & 86 & 0.5 & 70 & 208 \\
\hline NFEdisto & 63 & 32 & 463 & 457 & 37 & 7 & 0.5 & 56 & 182 \\
\hline NFEdisto & 32 & 55 & 273 & 273 & 37 & 19 & 2 & 11.5 & 276 \\
\hline SFEdisto & 418 & 381 & 691 & 624 & 69 & 260 & 12 & 146 & 92 \\
\hline SFEdisto & 303 & 298 & 388 & 383 & 71 & 276 & 7 & 20 & 133 \\
\hline Turkey & 1 & 1 & 79 & 79 & 63 & 1 & 0 & 0 & 7 \\
\hline Turkey & 2 & 2 & 77 & 77 & 43 & 1 & 0 & 0 & 17 \\
\hline Fishing & 10 & 10 & 293 & 293 & 13 & 11 & 3 & 0 & 102 \\
\hline Fishing & 7 & 7 & 94 & 94 & 21 & 5 & 0 & 1 & 43 \\
\hline
\end{tabular}

${ }^{a}$ After Lenat (1993). 
Table 17. Results of the analysis of similarity one-factor tests on benthic macroinvertebrate community data collected from Hester-Dendy artificial substrates deployed for 8 weeks at transects downstream and upstream from the five selected bridge sites, South Carolina, 2014 to 2016.

[Replicates were not included in the analysis of similarity except for environmental versus replicate samples. Bold values indicate statistically significant difference. ID, identifier; NA, not analyzed because less than two data groups existed for the category; Global $R$, a measure (between 0 and 1 ) of the degree of separation of the groups in two-dimensional space; $p$-value, probability value; EPT, Ephemeroptera, Plecoptera, and Trichoptera spp.]

\begin{tabular}{|c|c|c|c|c|c|c|c|}
\hline $\begin{array}{l}\text { Site ID (table 1) } \\
\text { (and taxa } \\
\text { analyzed) }\end{array}$ & $\begin{array}{l}\text { Total number } \\
\text { of Hester- } \\
\text { Dendy sam- } \\
\text { ples (number } \\
\text { of replicates) }\end{array}$ & $\begin{array}{l}\text { Analysis of } \\
\text { similarity } \\
\text { statistics }\end{array}$ & $\begin{array}{c}\text { Upstream } \\
\text { versus } \\
\text { downstream } \\
\text { location }\end{array}$ & $\begin{array}{l}\text { Environmental } \\
\text { versus replicate } \\
\text { samples }\end{array}$ & Canopy cover & Substrate type & $\begin{array}{l}\text { Distance from } \\
\text { to bridge }\end{array}$ \\
\hline Lynches & 4 & Global $R$ & 1.000 & NA & NA & NA & NA \\
\hline (all taxa) & (No replicates) & $p$-value & 0.333 & NA & NA & NA & NA \\
\hline (all taxa) & (No replicates) & $p$-value & 0.333 & NA & NA & NA & NA \\
\hline Turkey & 8 & Global $R$ & 0.156 & 0.051 & 0.26 & 0.325 & -0.063 \\
\hline (all taxa) & ( +6 replicates) & $p$-value & 0.143 & 0.296 & 0.179 & 0.110 & 0.590 \\
\hline SFEdisto & 7 & Global $R$ & 0.204 & -0.11 & NA & 0.53 & NA \\
\hline (all taxa) & ( +5 replicates $)$ & $p$-value & 0.171 & 0.812 & NA & 0.067 & NA \\
\hline $\begin{array}{l}\text { (EPT and } \\
\text { Chronomid) }\end{array}$ & (No replicates) & $p$-value & 0.667 & NA & NA & NA & NA \\
\hline NFEdisto & 4 & Global $R$ & 0 & NA & NA & NA & NA \\
\hline $\begin{array}{l}\text { (EPT and } \\
\text { Chronomid) }\end{array}$ & (No replicates) & $p$-value & 1.000 & NA & NA & NA & NA \\
\hline Turkey & 8 & Global $R$ & 0.406 & NA & 0.219 & 0.388 & 0.175 \\
\hline $\begin{array}{l}\text { (EPT and } \\
\text { Chronomid) }\end{array}$ & ( +6 replicates) & $p$-value & 0.057 & NA & 0.179 & 0.067 & 0.219 \\
\hline SFEdisto & 7 & Global $R$ & 0.222 & NA & NA & 0.592 & NA \\
\hline
\end{tabular}



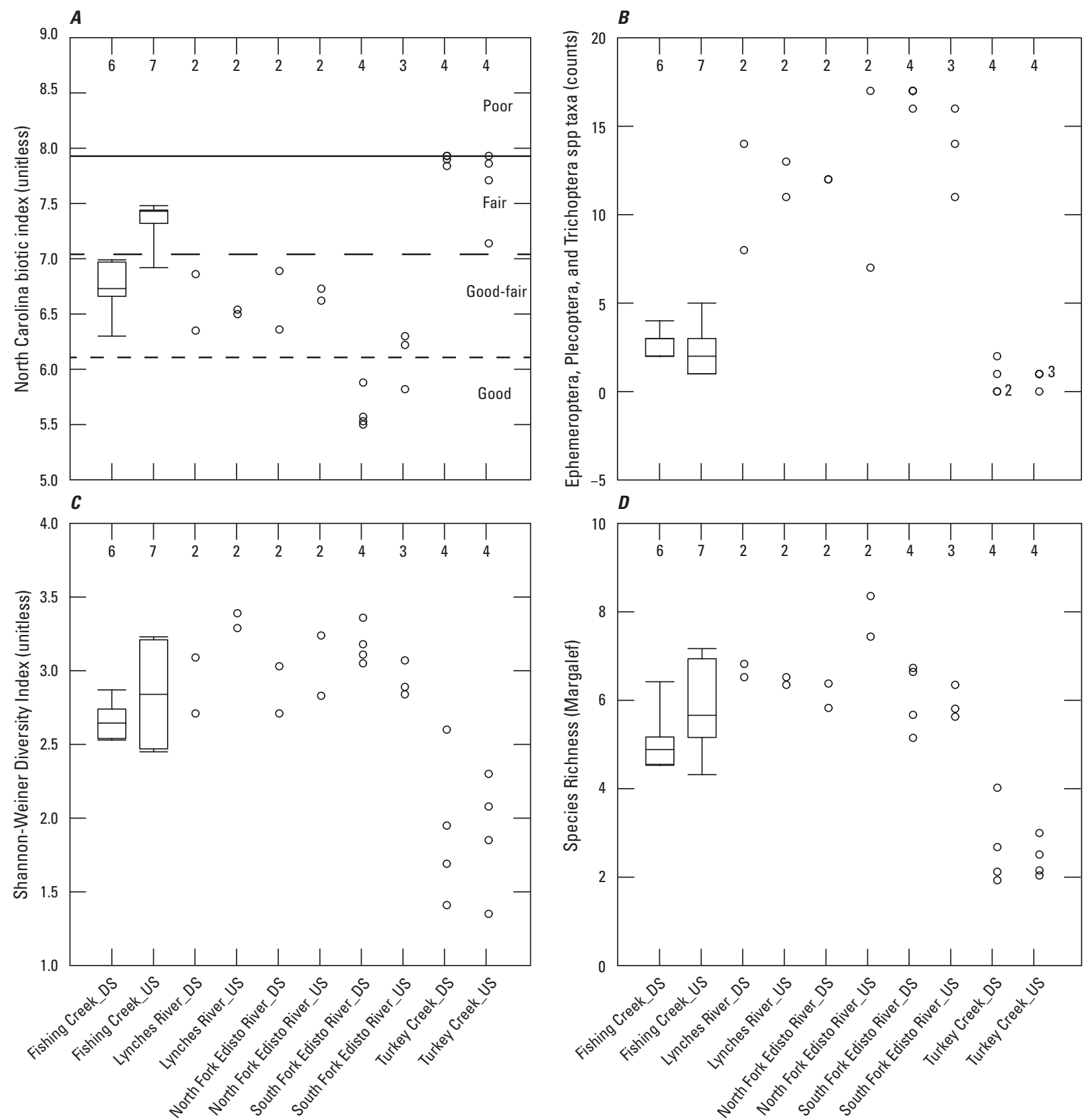

Bridge site (fig. 1; table 1)

\section{EXPLANATION}

14 Number of samples

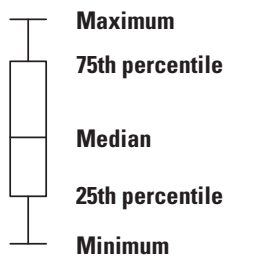

Note: Small circles are shown instead of a boxplot if the number of samples is five or less. The number beside the circle means that there is more than one sample at that location.

Figure 37. Boxplots showing biotic information computed using the benthic macroinvertebrate taxonomic data collected from Hester-Dendy artificial substrates deployed for 8 weeks at transects downstream and upstream from the five selected bridge sites, South Carolina, 2014 to 2016. $A$, North Carolina biotic indices. $B$, Ephemeroptera, Plecoptera, and Trichoptera spp. taxa. $C$, Shannon-Weiner diversity indices. $D$, Margalef species richness. 


\section{Summary}

The U.S. Geological Survey, in cooperation with the South Carolina Department of Transportation, investigated the effects of stormwater runoff from bridge decks on stream water conditions in South Carolina. This report describes the findings from the investigation that monitored 5 bridges in 3 physiographic provinces in South Carolina (Piedmont, Upper Coastal Plain, and Lower Coast Plain) that had a range of bridge, traffic, and hydrologic characteristics. The five selected South Carolina bridge sites (coincident with U.S. Geological Survey stations) included Lynches River at Effingham (station 02132000; U.S. Highway 52), North Fork Edisto River at Orangeburg (station 02173500; U.S. Highway 301), Turkey Creek above Huger (station 02172035; South Carolina Highway 41), South Fork Edisto River near Denmark (station 02173000; U.S. Highway 321), and Fishing Creek at Highway 5 below York (station 021473415; South Carolina Highway 5). Selected bridge sites represented a range of annual average daily traffic counts $(2,600$ to 24,300$)$, bridgedeck size (4,032 to 26,070 square feet), and receiving-water streamflows (near zero to 2,660 cubic feet per second). Bridge decks at the selected sites used open chutes, scuppers, and downspouts to drain stormwater directly into the receiving water at evenly spaced intervals rather than into collection basins or other structural stormwater collection systems.

From 2013 to 2018, data were collected and used (1) to compare to existing aquatic-life criteria, where available, during storm and nonstorm conditions and (2) to assess the downstream changes in receiving water-quality conditions during periods of observable stormwater runoff at five selected bridge decks. Additionally, sediment-quality conditions and benthic macroinvertebrate community structure upstream and downstream from the selected bridge sites were compared to assess cumulative integrated effects of bridge-deck runoff on receiving water. Stormwater-runoff data collection focused on capturing the evenly distributed release of stormwater from bridge-deck open chutes, scuppers, and downspouts by assessing stream water-quality conditions upstream (not affected by bridge-deck runoff) and downstream (affected by bridge-deck runoff) from the selected bridge sites. Depth-integrated, equal-width-increment methods were used to collect water samples instead of point or grab samples because equal-width-increment samples represent the entire stream cross section of the receiving water at a transect. For each storm, the quantity of bridge-deck runoff was estimated using existing bridge-deck runoff equations, based on rainfall amount and intensity.

During observable bridge-deck runoff (from rainfall, a total of five to six stream samples were collected concurrently upstream and downstream at each bridge site. Routine (nonstorm) sampling in the receiving water was conducted to collect 12 to 14 water samples upstream from the bridge sites during nonrunoff conditions. Therefore, total samples collected at the five bridge sites ranged from 17 to 20. Samples were analyzed for physical properties, suspended sediment, nutrients, major ions, trace metals, polycyclic aromatic hydrocarbons, and Escherichia coli (E. coli). Bridge-deck and streambed sediment at upstream and downstream transects were collected once at each bridge site and analyzed for metals and semivolatile organic compounds that included polycyclic aromatic hydrocarbons. Benthic macroinvertebrate community surveys were conducted once using Hester-Dendy multiplate artificial substrate samplers deployed concurrently at multiple upstream and downstream locations.

In total, 14 routine (nonstorm) and 5 storm samples were collected from January 2013 to March 2015 at the Lynches River at Effingham (Lynches) bridge site, which represented the greatest bridge-deck area $(26,070$ square feet), relatively high traffic counts (up to 18,400 vehicles), and greatest streamflow (up to 2,660 cubic feet per second) of the selected sites. Nutrients, trace metals, and suspended sediment exhibited similar concentration ranges among the sampled upstream transect during routine (nonstorm) conditions, upstream transect during storms, and downstream transect during storms. Based on permutation one-factor tests, bridge-deck runoff at the Lynches bridge site did not significantly alter physical properties, nutrient, trace-metal, and suspended-sediment concentrations in Lynches River at the transects downstream and upstream from the Lynches bridge site compared to the ambient conditions at the upstream transect location. Additionally, because trace-metal concentrations during storms were below the South Carolina Department of Health and Environmental Control freshwater aquatic life criteria during the period of study, there was no indication that stormwater runoff from the bridges would cause impaired aquatic-life conditions related to trace-metal concentrations in the Lynches River. During the period of study, E. coli concentrations remained well below the daily maximum criterion of 349 most probable number per 100 milliliters, with the maximum E. coli concentration of 137 most probable number per 100 milliliters occurring during storm sampling. Although the range of concentrations for the storms was slightly elevated relative to the routine conditions, permutation one-factor tests indicated that there were no statistically significant differences in $E$. coli concentrations between nonstorm and storm conditions. Of the 17 analyzed polycyclic aromatic hydrocarbon compounds in the 23 stream water samples (routine and storm), only three compounds were detected at extremely low concentrations (less than 0.05 microgram per liter), each just once, at the Lynches bridge site. Results of the Wilcoxon one-side paired test indicated that there was no statistically significant increase in nutrient, suspended-sediment, trace-metal, or E. coli concentrations downstream from the Lynches bridge site during storms.

Water samples were collected 14 times during routine and 6 times during storm conditions at the North Fork Edisto River at Orangeburg (NFEdisto) bridge site from January 2014 to March 2015, which represented the greatest traffic counts (up to 24,300 vehicles), second greatest bridge-deck area (15,714 square feet), and intermediate streamflow (up to 870 cubic feet per second). Nutrients, trace metals, 
and suspended sediment exhibited similar concentration ranges among the sampled upstream transect during routine (nonstorm) conditions, upstream transect during storms, and downstream transect during storms. Based on permutation one-factor tests, bridge-deck runoff at the NFEdisto bridge site did not significantly alter physical properties, nutrient, trace metals, and suspended-sediment concentrations at the transects downstream and upstream from the NFEdisto bridge site compared to the ambient conditions at the upstream transect. Results of the Wilcoxon one-side paired test indicated that there was no statistically significant increase in nutrient, suspended-sediment, or trace-metal concentrations downstream from the NFEdisto bridge site during storms. Additionally, because trace-metal concentrations during storms were below the freshwater aquatic-life criteria, stormwater runoff from the bridges did not cause impaired aquatic-life conditions related to trace-metal concentrations in the North Fork Edisto River. During the period of study, E. coli concentrations remained well below 349 most probable number per 100 milliliters, except for $E$. coli concentrations greater than 2,420 most probable number per 100 milliliters occurring during storm sampling at upstream and downstream transects at the NFEdisto bridge site that exceeded South Carolina Department of Health and Environmental Control daily maximum criterion. Although the permutation one-factor tests indicated that there were no statistically significant differences in E. coli concentrations between nonstorm and storm conditions, Wilcoxon paired tests indicated a statistically significant increase in E. coli concentrations downstream from the bridge during storms. However, changes in downstream E. coli concentrations were minor, increasing from 0 to $39 \mathrm{MPN} / 100 \mathrm{~mL}$ ( 0 to 28 percent) during storms, with the greater change occurring during period of greater rainfall intensity. Only 8 of the 17 analyzed PAHs were detected in stream water at extremely low concentrations (less than 0.05 microgram per liter) in routine samples only at the NFEdisto bridge site.

Water samples were collected 14 times during routine and 5 times during storm conditions from April 2015 to March 2017 at Turkey Creek above Huger (Turkey) bridge site, which represented one of the bridge sites with lesser traffic counts (2,600 to 2,700 vehicles), bridge-deck area (5,280 square feet), and streamflow (up to 57 cubic feet per second). Although median dissolved-oxygen concentrations were above the aquatic-life criterion of 4 milligrams per liter, dissolvedoxygen concentrations frequently fell to below 4 milligrams per liter under low streamflow conditions (less than 1 cubic foot per second) when minimal reaeration occurred. Physical properties, nutrients, trace metals, and suspended sediment exhibited similar concentration ranges among the sampled upstream transect during routine (nonstorm) conditions, upstream transect during storms, and downstream transect during storms. Based on permutation one-factor tests, bridge-deck runoff into Turkey Creek did not significantly alter physical properties, nutrient, trace metals, and suspendedsediment concentrations at the transects downstream and upstream from the Turkey bridge site compared to the ambient conditions at the upstream transect. Results of the Wilcoxon one-side paired test indicated that there was no statistically significant increase in nutrient, suspended-sediment, or trace-metal concentrations downstream from the Turkey bridge site during storms. At upstream and downstream transects at the Turkey bridge site, several trace-metal (lead, copper, selenium, and cadmium) concentrations in stream water exceeded aquatic-life criteria, but exceedances tended to occur more frequently at the upstream transect during routine (nonstorm related) sampling. Total chromium was the only trace metal that had concentrations statistically higher at the transect downstream than the upstream transect during the five storms. During the period of study, median E. coli concentrations remained below 349 most probable number per 100 milliliters, but the $E$. coli concentration did exceed the daily maximum criterion once during routine and storm sampling at upstream and downstream transects at the Turkey bridge site. The permutation one-factor test indicated that $E$. coli concentrations were not statistically different between nonstorm and storm conditions. The Wilcoxon paired test indicated no statistically significant increase in E. coli concentrations downstream from the bridge during storms. The Turkey bridge site had the most frequent detections of polycyclic aromatic hydrocarbons (4 routine and 4 storms), with 7 of the 17 analyzed compounds detected in stream water at low concentrations (less than 0.2 microgram per liter), and all detections were observed in samples collected during low streamflow (less than 1 cubic foot per second) conditions.

In total, 14 routine (nonstorm) and 5 storm samples were collected from April 2015 to May 2016 from the South Fork Edisto River near Denmark (SFEdisto) bridge site, which represented low to intermediate traffic counts (2,800 to 3,200 vehicles), bridge-deck size (10,244 square feet), and streamflow (up to 825 cubic feet per second). Physical properties, nutrients, trace metals, and suspended sediment exhibited similar concentration ranges among the sampled upstream transect during routine (nonstorm) conditions, upstream transect during storms, and downstream transect during storms. Based on permutation one-factor tests, bridge-deck runoff at the SFEdisto bridge site did not significantly alter physical properties, nutrient, trace metals, and suspended-sediment concentrations at the transects downstream and upstream from the SFEdisto bridge site compared to the ambient conditions at the upstream transect. Results of the Wilcoxon one-side paired test indicated that there was no statistically significant increase in physical properties, nutrient, suspended-sediment, or trace-metal concentrations downstream from the SFEdisto bridge site during storms. Total recoverable lead concentrations exceeded the criterion continuous concentration of 0.54 microgram per liter in 7 of the 14 routine samples (upstream transect) and in 2 of the 5 storm samples (upstream and downstream transects). During the period of study, E. coli concentrations remained below 349 most probable number per 100 milliliters (daily maximum criterion), except for one storm sample 
when E. coli concentration exceeded the criterion at both upstream and downstream transects at the SFEdisto bridge site (387 and 373 most probable number per 100 milliliters, respectively). Permutation one-factor test indicated that E. coli concentrations were not statistically different between nonstorm and storm conditions. The Wilcoxon paired test indicated no statistically significant increase in E. coli concentrations downstream from the bridge during storms. One polycyclic aromatic hydrocarbon compound, benzo $[b]$ fluoranthene, was detected once at an estimated concentration of 0.009 microgram per liter at the SFEdisto bridge site at the upstream transect during storm sampling.

The Fishing Creek at Highway 5 below York. (Fishing) bridge site was the only bridge site in the Piedmont physiographic province; from July 2016 to April 2018, 12 routine and 5 storm samples were collected at the Fishing bridge site, which represented intermediate traffic counts ( 8,700 to 9,000 vehicles), lesser bridge-deck size (4,032 square feet), and the least streamflow (up to 5.8 cubic feet per second). Although median dissolved-oxygen concentrations were above the aquatic-life criterion, dissolvedoxygen concentrations periodically fell to below 4 milligrams per liter under low streamflow conditions (less than 0.5 cubic foot per second) when minimal reaeration occurred. Results of the signed rank test indicated that turbidity, total nitrogen, and total organic nitrogen plus ammonia concentrations significantly increased downstream from the bridge during storms. Based on permutation one-factor tests, bridge-deck runoff at the Fishing bridge site did not significantly alter nutrient, trace metals, and suspended-sediment concentrations at the transects downstream and upstream from the Fishing bridge site compared to the ambient conditions at the upstream transect. Total recoverable lead concentrations periodically exceeded the criterion continuous concentration in 2 of the 12 routine samples (upstream transect) and in 2 of the 5 storm samples (upstream and downstream transects). During the period of study, E. coli concentrations were frequently above the daily maximum criterion during routine ( 2 out of 6 samples) and storm ( 7 out of 10 samples) samplings. The permutation one-factor test indicated that E. coli concentrations were not statistically different between nonstorm and storm conditions. The Wilcoxon paired test indicated no statistically significant increase in E. coli concentrations downstream from the bridge during storms. The polycyclic aromatic hydrocarbon compound, fluorene, was detected once, and acenaphthene was detected twice at low concentrations (less than 0.05 microgram per liter) at the upstream transect during routine sampling.

Trace-metal concentrations in composited streambed sediments at upstream and downstream transects at the five bridge sites were compared to corresponding threshold and probable effect concentrations to determine if trace metals accumulated in the bed sediment above levels that could (threshold) or probably do (probable) affect the health of benthic macroinvertebrate communities. In general, trace-metal concentrations were below the effect levels at all sites, except at the upstream transect at the Fishing bridge site where a chromium concentration of 45.1 milligrams per kilogram exceeded the threshold effect concentration of 43.4 milligrams per kilogram. Aluminum-normalized trace-metal concentrations were computed and used to develop enrichment ratios of the 12 trace metals in downstream sediment. Overall, bridge sites had enrichment ratios that did not indicate any change in trace-metal concentrations in downstream bed sediment, except lead at the Lynches bridge site and manganese at the Fishing bridge site. In conclusion, bridge-deck runoff did not seem to influence trace-metal accumulation in the streambed sediment downstream from the bridge.

Polycyclic aromatic hydrocarbon concentrations in composited streambed sediments at upstream and downstream transects at the five bridge sites were compared to corresponding threshold and probable effect concentrations to determine if polycyclic aromatic hydrocarbons accumulated in the bed sediment. Individual compound concentrations and the sum of 18 compounds did not exceed any threshold and probable effect concentrations, indicating that polycyclic aromatic hydrocarbon concentrations in the bed sediment at downstream and upstream transects were not likely to have an effect on the health of benthic macroinvertebrate communities. Nonetheless, the smaller Turkey and Fishing bridge sites had greater cumulative polycyclic aromatic hydrocarbon concentrations in the downstream sediment (105.8 and 85.81 micrograms per kilogram, respectively) than the upstream sediment ( 0 and 28.57 micrograms per kilogram, respectively). Although the cumulative polycyclic aromatic hydrocarbon concentrations in downstream sediment at these sites were well below the threshold effect concentration of 1,610 micrograms per kilogram, the 3- to 100 -fold increase in downstream concentrations demonstrated a strong probability of a bridge-runoff source.

Changes in benthic macroinvertebrate communities between upstream and downstream transects, canopy cover, and substrate types were assessed using multivariate statistical analysis, analysis of similarity, and similarity profile analysis. Biological metrics of computed North Carolina biotic indices, Ephemeroptera-Plecoptera-Trichoptera (EPT) taxa counts, Shannon-Weiner diversity indices, and Margalef species richness also were compared between upstream and downstream transects. Overall, benthic macroinvertebrate health downstream from the bridge seemed to not be affected by bridge-deck runoff, based on multivariate statistical analyses that indicated statistically similar benthic macroinvertebrate communities at upstream and downstream transects. One exception was for the Fishing bridge site, where benthic communities were different between the upstream and downstream transects. That difference seemed to be explained by differences in substrate type. For upstream and downstream transects at the five bridge sites, chronomids and tubificid worms had the most individuals of all the benthic taxa, followed by EPT taxa. For upstream and downstream transects at the NFEdisto, Turkey, and Fishing bridge sites, EPT taxa 
had few species present. Of the five bridge sites in this study, the Turkey bridge site seemed to have the least healthy benthic macroinvertebrate communities, with the lowest EPT taxa, species richness, and diversity and the highest biotic indices, indicative of poorer ecological health, at upstream and downstream transects. This ecological finding was not unexpected because of seasonal periods of negligible flow when dissolved-oxygen concentrations fell below 4 milligrams per liter during this study period. Of the five bridge sites in this study, the SFEdisto bridge site seemed to have the most diverse and more sensitive benthic macroinvertebrate communities at upstream and downstream transects.

\section{References Cited}

Abrahim, G.M.S., and Parker, R.J., 2008, Assessment of heavy metal enrichment factors and the degree of contamination in marine sediments from Tamaki Estuary, Auckland, New Zealand: Environmental Monitoring and Assessment, v. 136, nos. 1-3, p. 227-238. [Also available at https://doi.org/10.1007/s10661-007-9678-2.]

Amiard, J.C., Amiard-Triquet, C., Berthet, B., and Metayer, C., 1987, Comparative study of the patterns of bioaccumulation of essential $(\mathrm{Cu}, \mathrm{Zn})$ and non-essential $(\mathrm{Cd}, \mathrm{Pb})$ trace metals in various estuarine and coastal organisms: Journal of Experimental Marine Biology and Ecology, v. 106, no. 1, p. 73-89. [Also available at https://doi.org/10.1016/0022-0981(87)90148-1.]

Amatya, D.M., Callahan, T.J., Hansen, W., Trettin, C.T., Radecki-Pawlik, A., and Meire, P., 2015, Turkey Creek-A case study of ecohydrology and integrated watershed management in the low-gradient Atlantic Coastal Plain, USA: Journal of Water Resource and Protection, v. 7, no. 10, p. 792-814. [Also available at https://doi.org/10.4236/jwarp.2015.710065.]

Amatya, D.M., Callahan, T.J., Trettin, C.T., and RadeckiPawlik, A., 2009, Hydrologic and water quality monitoring on Turkey Creek Watershed, Francis Marion National Forest, SC: St. Joseph, Mich., American Society of Agricultural and Biological Engineers Meeting Paper Number 095999. [Also available at https://doi.org/10.13031/2013.27029.]

Amatya, D.M., and Trettin, C.T., 2008, An eco-hydrologic project on Turkey Creek Watershed, South Carolina, U.S.A., in Meire. P., Coenen, M., Lombardo, C., Robba, M., and Sacile, R., eds., Integrated water management-Practical experiences and case studies: Dordrecht, The Netherlands, Springer, p. 115-126.
Amatya, D.M., Trettin, C.T., Panda, S., and Ssegane, H., 2013, Application of LiDAR data for hydrologic assessments of low-gradient coastal watershed drainage characteristics: Journal of Geographic Information System, v. 5, no. 2, p. 175-191. [Also available at https://doi.org/10.4236/ jgis.2013.52017.]

Anderson, C.W., 2005, Turbidity (ver. 2.1): U.S. Geological Survey Techniques of Water-Resources Investigations, book 9, chap. A6., sec. 6.7, September 2006, accessed September 27, 2019, from http://pubs.water.usgs.gov/twri9A6/.

Barbour, M.T., Gerritsen, J., Snyder, B.D., and Stribling, J.B., 1999, Rapid bioassessment protocol for use in streams and wadeable rivers - Periphyton, benthic macroinvertebrates, and fish (2d ed.): Washington, D.C., U.S. Environmental Protection Agency, Office of Water, Merrimack Station, AR-1164, EPA841-B-99-002, 337 p. [Also available at https://www3.epa.gov/region1/npdes/merrimackstation/ pdfs/ar/AR-1164.pdf.]

Benjamini, Y., and Hochberg, Y., 1995, Controlling the false discovery rate-A practical and powerful approach to multiple testing: Journal of the Royal Statistical SocietySeries B (Methodological), v. 57, no. 1, p. 289-300. [Also available at https://doi.org/10.1111/j.2517-6161.1995. tb02031.x.]

Bradley, P.M., Journey, C.A., Chapelle, F.H., Lowery, M.A., and Conrads, P.A., 2010, Flood hydrology and methylmercury availability in Coastal Plain rivers: Environmental Science \& Technology, v. 44, no. 24, p. 9285-9290. [Also available at https://doi.org/10.1021/ es 102917 j.]

Casey, R.J., and Kendall, S.A., 1997, Sample number and colonization patters of benthic macroinvertebrates and organic material on artificial and natural substrata: Journal of Freshwater Ecology, v. 12, no. 4, p. 577-584. [Also available at https://doi.org/10.1080/02705060.1997.9663572.]

Childress, C.J.O., Foreman, W.T., Connor, B.F., and Maloney, T.J., 1999, New reporting procedures based on longterm method detection levels and some considerations for interpretations of water-quality data provided by the U.S. Geological Survey National Water Quality Laboratory: U.S. Geological Survey Open-File Report 99-193, 19 p. [Also available at https://doi.org/10.3133/ofr99193.]

Clarke, K.R., 1993, Non-parametric multivariate analyses of changes in community structure: Australian Journal of Ecology, v. 18, no. 1, p. 117-143, accessed March 17, 2017, at https://doi.org/10.1111/j.1442-9993.1993.tb00438.x.

Clarke, K.R., and Gorley, R.N., 2015, Primer version 7-User manual/tutorial: Plymouth, U.K., PRIMER-e, 296 p. 
Clarke, K.R., Gorley, R.N., Somerfield, P.J., and Warwick, R.M., 2014, Change in marine communities-An approach to statistical analysis and interpretation: Plymouth, U.K., PRIMER-e, 260 p.

Clesceri, L.S., Greenberg, A.E., and Eaton, A.D., eds., 1998, 3120 metals by plasma emission spectroscopy, in Standard methods for the examination of water and wastewater (20th ed.): Washington, D.C., American Public Health Association, p. 3-37 to 3-43.

Driscoll, E.D., Shelley, P.E., and Strecker, E.W., 1988, Constituent loadings and impacts from highway stormwater runoff, Volume I-Design procedure: Federal Highway Administration Publication, FHWA-RD-88-006, 23 p.

Dupuis, T.V., 2002, Assessing the impacts of bridge deck runoff contaminants in receiving waters: Transportation Research Board, National Research Council, National Cooperative Highway Research Program Report 474.

Edwards, T.K., and Glysson, G.D., 1999, Field methods for measurement of fluvial sediment: U.S. Geological Survey, Techniques of Water-Resources Investigations, book 3, chap. C2, 89 p. [Also available at https://pubs.usgs.gov/twri/ twri3-c2/.]

Fishman, M.J., ed., 1993, Methods of analysis by the U.S. Geological Survey National Water Quality Laboratory-Determination of inorganic and organic constituents in water and fluvial sediments: U.S. Geological Survey Open-File Report 93-125, 217 p. [Also available at https://doi.org/10.3133/ofr93125.]

Fishman, M.J., and Friedman, L.C., 1989, Methods for determination of inorganic substances in water and fluvial sediments: U.S. Geological Survey Techniques of Water-Resources Investigations, book 5, chap. A1, 545 p. [Also available at https://doi.org/10.3133/twri05A1.]

Garbarino, J.R., and Damrau, D.L., 2001, Methods of analysis by the U.S. Geological Survey National Water Quality Laboratory-Determination of organic plus inorganic mercury in filtered and unfiltered natural water with cold vapor-Atomic fluorescence spectrometry: U.S. Geological Survey Water-Resources Investigations Report 2001-4132, 16 p. [Also available at https://doi.org/10.3133/wri014132.]

Garbarino, J.R., Kanagy, L.K., and Cree, M.E., 2006, Determination of elements in natural-water, biota, sediment and soil samples using collision/reaction cell inductively coupled plasma-mass spectrometry: U.S. Geological Survey Techniques and Methods, book 5, chap. B1, 88 p.
Garbarino, J.R., and Struzeski, T.M., 1998, Methods of analysis by the U.S. Geological Survey National Water Quality Laboratory-Determination of elements in wholewater digests using inductively coupled plasma-optical emission spectrometry and inductively coupled plasmamass spectrometry: U.S. Geological Survey Open-File Report 98-165, 101 p. [Also available at https://doi.org/10.3133/ofr98165.]

Granato, G.E., 2003, National highway runoff water-quality data and methodology synthesis, volume III-Availability and documentation of published information of synthesis of regional or national highway-runoff quality data: Federal Highway Administration Publication, FHWA-EP-03-056, 71 p. [Also available at https://rosap.ntl.bts.gov/view/ dot/38621.]

Harden, W., 2002, Total maximum daily load development for fishing creek and tributaries (stations: CW-005, CW-006, CW-008, CW-029, CW-096, CW-212, CW-224, CW-225, CW-227, CW-233, and CW-234) for fecal coliform bacteria (HUC 03050103): South Carolina Department of Health and Environmental Control, Bureau of Water, accessed February 26, 2019, at https://www.scdhec.gov/sites/default/files/docs/ HomeAndEnvironment/Docs/tmdlfish.pdf.

Harned, D.A., 1987, Effects of highway runoff on streamflow and water quality in the Sevenmile Creek basin, a rural area in the Piedmont Province of North Carolina, July 1981 to July 1982: U.S. Geological Survey Water Supply Paper 2329, 33 p. [Also available at https://doi.org/10.3133/ wsp2329.]

Harrell, F.E., Jr., 2018, Hmisc-Harrell Miscellaneous: GitHub, R package, accessed August 30, 2018, at https://github.com/harrelfe/Hmisc.

Helsel, D.R., 2005, Nondetects and data analysis - Statistics for censored environmental data: Hoboken, N.J., WileyInterscience, John Wiley \& Sons, 250 p.

Helsel, D.R., and Hirsch, R.M., 1992, Statistical methods in water resources (1st ed.): Amsterdam, The Netherlands, Elsevier Science Publishers, Studies in Environmental Science no. 49, 522 p.

Hoffman, G.L., Fishman, M.J., and Garbarino, J.R., 1996, Methods of analysis by the U.S. Geological Survey National Water Quality Laboratory-In-bottle acid digestion of whole-water samples: U.S. Geological Survey Open-File Report 96-225, 28 p. [Also available at https://doi.org/10.3133/ofr96225.]

Hothorn, T., Hornik, K., Wiel, M.A. van de, and Zeileis, A., 2008, Implementing a class of permutation testsThe coin package: Journal of Statistical Software, v. 28, no. 8, p. 1-23, accessed August 30, 2018, at https://doi.org/10.18637/jss.v028.i08. 
Hothorn, T., Winell, H., Hornik, K., Wiel, M.A. van de, and Zeileis, A., 2017, coin-Conditional inference procedures in a permutation test framework: R package, accessed on August 30, 2018, at http://coin.r-forge.r-project.org.

Ingersoll, C.G., MacDonald, D.D., Wang, N., Crane, J.L., Field, L.F., Haverland, P.S., Kemble, N.E., Lindskoog, R.A., Severn, C., and Smorong, D.E., 2000, Prediction of sediment toxicity using consensus-based freshwater sediment quality guidelines: Chicago, Ill., U.S. Environmental Protection Agency, EPA 905/R-00007, 25 p. [Also available at https://www.cerc.usgs.gov/ pubs/center/pdfdocs/91126.pdf.]

Irwin, G.A., and Losey, G.T., 1978, Water-quality assessment of runoff from a rural highway bridge near Tallahassee, Florida: U.S. Geological Survey Water-Resources Investigations Report 79-1, 27 p. [Also available at https://doi.org/10.3133/wri791.]

Jens, S.W., 1979, Design of urban highway drainage-The state of the art: Washington, D.C., Federal Highway Administration Report FHWA-TS-79-225. [Also available at https://www.fhwa.dot.gov/engineering/hydraulics/pubs/ ts79_225.pdf.]

Journey, C.A., Beaulieu, K.M., and Bradley, P.M., 2013, Environmental factors that influence cyanobacteria and geosmin occurrence in reservoirs, in Bradley, P.M., ed., Current perspectives in contaminant hydrology and water resources sustainability: IntechOpen, accessed May 15, 2013, at https://doi.org/10.5772/47884. [Chapter directly accessible at https://doi.org/10.5772/54807.]

Knott, J.M., Glysson, G.D., Malo, B.A., and Schroeder, L.J., 1993, Quality assurance plan for the collection and processing of sediment data by the U.S. Geological Survey, Water Resources Division: U.S. Geological Survey OpenFile Report 92-499, accessed November 17, 2010, at https://doi.org/10.3133/ofr92499.

Krein, A., and Schorer, M., 2000, Road runoff pollution by polycyclic aromatic hydrocarbons and its contribution to river sediments: Water Research, v. 34, no. 16, p. 41104115. [Also available at https://doi.org/10.1016/S00431354(00)00156-1.]

Leahy, J.G., and Colwell, R.R., 1990, Microbial degradation of hydrocarbons in the environment: Microbiological Reviews, v. 54, no. 3, p. 305-315. [Also available at https://www.ncbi.nlm.nih.gov/pmc/articles/PMC372779/.]

Lenat, D.R., 1993, A biotic index for the southeastern United States-Derivation and list of tolerance values, with criteria for assigning water-quality ratings: Journal of the North American Benthological Society, v. 12, no. 3, p. 279290. [Also available at https://doi.org/10.2307/1467463.]
Lorenz, D.L., and DiCicco, L., 2017, smwrStats-R functions to support statistical methods in water resources: GitHub, R package, accessed October 1, 2015 at https:/github.com/ USGS-R/smwrStats/.

Lorenz, D.L., and Diekoff, A.L., 2017, smwrGraphs-An R package for graphing hydrologic data, version 1.1.2: U.S. Geological Survey Open-File Report 2016-1188, 17 p. [Also available at https://doi.org/10.3133/ofr20161188; supersedes USGS Open-File Report 2015-1202.]

MacDonald, D.D., Ingersoll, C.G., and Berger, T.A., 2000, Development and evaluation of consensus-based sediment quality guidelines for freshwater ecosystems: Archives of Environmental Contamination and Toxicology, v. 39, no. 1, p. 20-31. [Also available at https://doi.org/10.1007/ s002440010075.]

Malina, J.F., Jr., Barrett, M.E., Jackson, A., and Kramer, T., 2005, Characterization of stormwater runoff from a bridge deck and approach highway, effects on receiving water quality: Center for Transportation Research, University of Texas at Austin, Federal Highway Administration Publication (FHWA/TX-06/0-4543-1), 88 p. [Also available at http://ctr.utexas.edu/wp-content/uploads/ pubs/0_4543_1.pdf.]

Maloney, T.J., ed., 2005, Quality management system, U.S. Geological Survey National Water Quality Laboratory: U.S. Geological Survey Open-File Report 2005-1263, 93 p. [Also available at https://doi.org/10.3133/ofr20051263.]

Marsalek, J., Brownlee, B., Mayer, T., Lawal, S., and Larkin, G.A., 1997, Heavy metals and PAHs in stormwater runoff from the Skyway Bridge, Burlington, Ontario: Water Quality Research Journal of Canada, v. 32, no. 4, p. 815-828. [Also available at https://doi.org/10.2166/ wqrj.1997.044.]

McKenzie, D.J., and Irwin, G.A., 1983, Water quality assessment of stormwater runoff from a heavily used urban highway bridge in Miami, Florida: U.S. Geological Survey Water-Resources Investigations Report 83-4153, 45 p. [Also available at https://doi.org/10.3133/wri834153.]

Merritt, R.W., and Cummins, K.W., eds., 1996, An introduction to the aquatic insects of North America (3d ed.): Debuque, Iowa, Kendall Hunt Publishing Company, $861 \mathrm{p}$.

Morgali, J.R., and Linsley, R.K., 1965, Computer analysis of overland flow: Journal of the Hydraulics Division, v. 91, HY3, p. 81-101. 
Mueller, D.K., Schertz, T.L., Martin, J.D., and Sandstrom, M.W., 2015, Design, analysis, and interpretation of field quality-control data for water-sampling projects: U.S. Geological Survey Techniques and Methods, book 4, chap. C4, 54 p. [Also available at https://doi.org/10.3133/ tm4C4.]

Myers, D.N., Stoeckel, D.M., Bushon, R.N., Francy, D.S., and Brady, A.M.G., 2014, Fecal indicator bacteria (ver. 2.1, May 2014): U.S. Geological Survey Techniques of WaterResources Investigations, book 9, chap. A7, sec. 7.1, accessed August 10, 2018, at https://pubs.water.usgs.gov/ twri9A7/.

National Academies of Sciences, Engineering, and Medicine, 2014, Bridge stormwater runoff analysis and treatment options: Washington, D.C., The National Academies Press, 197 p. [Also available at https://doi.org/10.17226/22395.]

Patton, C.J., and Kryskalla, J.R., 2011, Colorimetric determination of nitrate plus nitrite in water by enzymatic reduction, automated discrete analyzer methods: U.S. Geological Survey Techniques and Methods, book 5, chap. B8. [Also available at https://doi.org/10.3133/tm5B8.]

Patton, C.J., and Truitt, E.P., 1992, Methods of analysis by the U.S. Geological Survey National Water Quality Laboratory - Determination of total phosphorus by a Kjeldahl digestion method and an automated colorimetric finish that includes dialysis: U.S. Geological Survey Open-File Report 92-146, 39 p. [Also available at https://doi.org/10.3133/ofr92146.]

Patton, C.J., and Truitt, E.P., 2000, Methods of analysis by the U.S. Geological Survey National Water Quality Laboratory-Determination of ammonium plus organic nitrogen by a Kjeldahl digestion method and an automated photometric finish that includes digest cleanup by gas diffusion: U.S. Geological Survey Open-File Report 00-170, 31 p. [Also available at https://doi.org/10.3133/ ofr00170.]

Pennington, W., 2016, Standard operating procedures for processing, identification, and enumeration of invertebrate samples: Cookeville, Tenn., Pennington and Associates, Inc.

Pitt, R.E., and Maestre, A., 2005, Stormwater quality as described in the National Stormwater Quality database (NSQD) - Proceedings of the 10th International Conference on Urban Drainage, Copenhagen, Denmark, August 21-25, 2005: Tuscaloosa, Ala., The University of Alabama, 8 p.

Radtke, D.B., 2005, Bottom-material samples: U.S. Geological Survey Techniques of Water-Resources Investigations, book 9, chap. A8, accessed February 13, 2009, at https://pubs.water.usgs.gov/twri9A8/.
Rantz, S.E., and others, 1982, Measurement and computation of streamflow: U.S. Geological Survey Water-Supply Paper 2175, 2 vols., 631 p. [Also available at https://pubs.usgs. gov/wsp/wsp2175/]

Rice, E.W., Baird, R.B., Eaton, A.D., and Clesceri, L.S., eds., 2012, 9223 B. enzyme substrate test, in Standard methods for the examination of water and wasterwater ( $22 \mathrm{~d}$ ed.): American Public Health Association, p. 9-93 to 9-94.

Riva-Murray, K., Bradley, P.M., Scudder Eikenberry, B.C., Knightes, C.D., Journey, C.A., Brigham, M.E., and Button, D.T., 2013, Optimizing stream water mercury sampling for calculation of fish bioaccumulation factors: Environmental Science \& Technology, v. 47, no. 11, p. 5904-5912, accessed May 15, 2013, at https://doi.org/10.1021/ es303758e.

Romanok, K.M., Journey, C.A., Petkewich, M.K., and Bradley, P.M., 2020, Water-, sediment-, and biologicalquality data for waters receiving runoff from five bridges in South Carolina, 2013 to 2018: U.S. Geological Survey data release, https://doi.org/10.5066/P9FXSV2Y.

Rosenberg, D.M., and Resh, V.H., 1982, The use of artificial substrates in the study of freshwater benthic macroinvertebrates, in Cairns, J., Jr., ed., Artificial substrates: Ann Arbor, Mich., Ann Arbor Science Publishers, Inc., p. 175-235.

Shreve, E.A., and Downs, A.C., 2005, Quality-assurance plan for the analysis of fluvial sediment by the U.S. Geological Survey Kentucky Water Science Center Sediment Laboratory: U.S. Geological Survey Open-File Report 2005-1230, 28 p. [Also available at https://doi.org/10.3133/ ofr20051230.]

Sinex, S.A., and Helz, G.R., 1981, Regional geochemistry of trace elements in Chesapeake Bay sediments: Environmental Geology, v. 3, no. 6, p. 315-323. [Also available at https://doi.org/10.1007/BF02473521.]

Singh, K.P., Malik, A., Sinha, S., Singh, V.K., and Murthy, R.C., 2005, Estimation of source of heavy metal contamination in sediments of Gomti River (India) using principal component analysis: Water, Air, and Soil Pollution, v. 166, nos. 1-4, p. 321-341. [Also available at https://doi.org/10.1007/s11270-005-5268-5.]

Smith, K.P., 2002, Effectiveness of three best management practices for highway-runoff quality along the southeast expressway, Boston, Massachusetts: U.S. Geological Survey Water-Resources Investigations Report 02-4059, 62 p. [Also available at https://pubs.usgs.gov/wri/wri024059/.] 
Smith, K.P., and Granato, G.E., 2010, Quality of stormwater runoff discharged from Massachusetts highways, 2005-07: U.S. Geological Survey Scientific Investigations Report 2009-5269, 198 p. [Also available at https://pubs.usgs.gov/ sir/2009/5269/ and on CD-ROM.]

South Carolina Department of Health and Environmental Control, 2012a, Watershed water quality assessmentEdisto River Basin: Columbia, S.C., South Carolina Department of Health and Environmental Control, Bureau of Water, 118 p., accessed October 1, 2018, at https://www.scdhec.gov/sites/default/files/docs/ HomeAndEnvironment/Docs/Watershed/wwqa/Edisto_ WWQA_2012.pdf.

South Carolina Department of Health and Environmental Control, 2012b, Watershed water quality assessmentCatawba River Basin: Columbia, S.C., South Carolina Department of Health and Environmental Control, Bureau of Water, 128 p., accessed October 1, 2018, at https://wwwprod.dhec.sc.gov/HomeAndEnvironment/Docs/ catawba.pdf.

South Carolina Department of Health and Environmental Control, 2014a, State of South Carolina integrated report for 2014, Part I-Section 303(d) list of impaired waters: South Carolina Department of Health and Environmental Control, 85 p., accessed January 12, 2017, at https://scdhec.gov/sites/default/files/docs/ HomeAndEnvironment/Docs/tmdl_14-303d.pdf.

South Carolina Department of Health and Environmental Control, 2014b, State of South Carolina integrated report for 2014, Part II-Section 305(b) assessment and reporting: South Carolina Department of Health and Environmental Control, 55 p., accessed January 12, 2017, at https://scdhec.gov/sites/default/files/ docs/HomeAndEnvironment/Docs/tmdl_14-305b.pdf.

South Carolina Department of Health and Environmental Control, 2014c, R.61-68, water classifications \& standards: Columbia, S.C., South Carolina Department of Health and Environmental Control, Bureau of Water, 65 p., accessed August 13, 2018, at https://www.scdhec.gov/sites/default/ files/Library/Regulations/R.61-68.pdf.

South Carolina Department of Health and Environmental Control, 2015, Watershed water quality assessmentPee Dee River Basin: Columbia, S.C., South Carolina Department of Health and Environmental Control, Bureau of Water, 407 p., accessed June 13, 2019, at https://www.scdhec.gov/sites/default/files/docs/ HomeAndEnvironment/Docs/Watershed/wwqa/Pee_Dee_ WWQA_2015.pdf.
South Carolina Department of Health and Environmental Control, 2017a, Certification requirements for enzyme substrate test procedures for total coliform/E.coli, E. coli, and fecal coliforms: South Carolina Department of Health and Environmental Control, accessed on August 13, 2018, at https://www.scdhec.gov/sites/default/files/ docs/Environment/docs/Enzyme\%20Substrate\%20 Certification\%20Requirements.pdf.

South Carolina Department of Health and Environmental Control, 2017b, 03040202-07 (Lynches River): South Carolina Department of Health and Environmental Control, accessed September 7, 2018, at https://www.scdhec.gov/ sites/default/files/docs/HomeAndEnvironment/Docs/4020207.pdf.

South Carolina Department of Transportation, 2018, Traffic counts: South Carolina Department of Transportation, digital data, accessed August 22, 2018, at https://www.scdot.org/travel/travel-trafficdata.aspx.

Stoker, Y.E., 1996, Effectiveness of a stormwater collection and detention system for reducing constituent loads from bridge runoff in Pinellas County, Florida: U.S. Geological Survey Open-File Report 96-484, 38 p. [Also available at https://doi.org/10.3133/ofr96484.]

Turnipseed, D.P., and Sauer, V.B., 2010, Discharge measurements at gaging stations: U.S. Geological Survey Techniques and Methods book 3, chap. A8, 87 p. (Also available at https://pubs.usgs.gov/tm/tm3-a8/.)

U.S. Environmental Protection Agency, 1998, Microwave assisted acid digestion of sediments, sludges, soils, and oils (rev. 1, February 2007): U.S. Environmental Protection Agency, Method 3051A, 25 p. [Also available at https://www.epa.gov/sites/production/files/2015-12/ documents/3051a.pdf.]

U.S. Geological Survey, 2006, Collection of water samples (ver. 2.0, September 2006): U.S. Geological Survey Techniques of Water-Resources Investigations, book 9, chap. A4, accessed August 10, 2018, at https://pubs.water.usgs.gov/twri9A4/.

U.S. Geological Survey, 2016, USGS water data for the Nation: U.S. Geological Survey National Water Information System database, accessed September 28, 2016, at https://doi.org/10.5066/F7P55KJN.

U.S. Geological Survey, variously dated, National field manual for the collection of water-quality data: U.S. Geological Survey Techniques of Water-Resources Investigations, book 9, chaps. A1-A9, accessed April 6, 2011, at https://pubs.water.usgs.gov/twri9A. 
Wagner, C.R., Fitzgerald, S.A., Sherrell, R.D., Harned, D.A., Staub, E.L., Pointer, B.H., and Wehmeyer, L.L., 2011, Characterization of stormwater runoff from bridges in North Carolina and the effects of bridge deck runoff on receiving streams: U.S. Geological Survey Scientific Investigations Report 2011-5180, 95 p. [Also available at https://doi.org/10.3133/sir20115180.]

Wanielista, M.P., Yousef, Y.A., and Christopher, J.E., 1980, Management of runoff from highway bridges: Florida Department of Transportation Final Report, FL-ER-10-80, $140 \mathrm{p}$.

Wei, T., 2017, corrplot-Visualization of a correlation matrix: GitHub, R package, accessed August 30, 2018, at https://github.com/taiyun/corrplot.

Wilde, F.D., ed., 2004, Cleaning of equipment for water sampling (ver. 2.0, April 2004): U.S. Geological Survey Techniques of Water-Resources Investigations, book 9, chap. A3, accessed August 10, 2018, at https://pubs.water. usgs.gov/twri9A3/.

Wilde, F.D., ed., variously dated, Field measurements: U.S. Geological Survey Techniques of Water-Resources Investigations, book 9, chap. A6, with sec. 6.0-6.8, accessed on August 10, 2018, at https://pubs.water.usgs.gov/ twri9A6/.

Wilde, F.D., Radtke, D.B., Gibs, J., and Iwatsubo, R.T., eds., 2004, Processing of water samples (ver. 2.2, April 2004): U.S. Geological Survey Techniques of Water-Resources Investigations, book 9, chap. A5, accessed August 10, 2018, at https://pubs.water.usgs.gov/twri9A5/.

Winston, R.J., Lauffer, M.S., Narayanaswamy, K., McDaniel, A.H., Lipscomb, B.S., Nice, A.J., and Hunt, W.F., 2015, Comparing bridge deck runoff and stormwater control measure quality in North Carolina: Journal of Environmental Engineering, v. 141, no. 1, 14 p. [Also available at https://doi.org/10.1061/(ASCE)EE.19437870.0000864.]
Yousef, Y.A., Wanielista, M.P., Hvitved-Jacobsen, T., and Harper, H.H., 1984, Fate of heavy metals in stormwater runoff from highway bridges: The Science of the Total Environment, v. 33, nos. 1-4, p. 233-244. [Also available at https://doi.org/10.1016/0048-9697(84)90397-8.]

Yunker, M.B., Macdonald, R.W., Vingarzan, R., Mitchell, R.H., Goyette, D., and Sylvestre, S., 2002, PAHs in the Fraser River Basin-A critical appraisal of PAH ratios as indicators of PAH source and composition: Organic Geochemistry, v. 33, no. 4, p. 489-515. [Also available at https://doi.org/10.1016/S0146-6380(02)00002-5.]

Zaugg, S.D., Burkhardt, M.R., Burbank, T.L., Olsen, M.C., Iverson, J.L., and Schroeder, M.P., 2006, Determination of semivolatile organic compounds and polycyclic aromatic hydrocarbons in solids by gas chromatography/ mass spectrometry: U.S. Geological Survey Techniques and Methods, book 5, chap. B3, 44 p. [Also available at https://doi.org/10.3133/tm5B3.]

Zellhoefer, W.F., 1989, Investigation of water quality impacts of stormwater runoff from Robert E. Lee Bridge, Richmond, Virginia: Virginia Department of Transportation, 40 p.

Zhang, W., Feng, H., Chang, J., Qu, J., Xie, H., and Yu, L., 2009, Heavy metal contamination in surface sediments of the Yangtze River intertidal zone-An assessment from different indexes: Environmental Pollution, v. 157, no. 5, p. 1533-1543. [Also available at https://doi.org/10.1016/j. envpol.2009.01.007.] 

